\title{
NANOSZERKEZETEK MECHANOKÉMIAI ELŐÁLLÍTÁSA ÉS MÓDOSÍTÁSI LEHETŐSÉGEINEK VIZSGÁLATA
}

\author{
Ph.D. ÉRTEKEZÉS
}

KOZMA GÁBOR

KÖRNYEZETTUDOMÁNYI DOKTORI ISKOLA

SZEGEDI TUDOMÁNYEGYETEM

TERMÉSZETTUDOMÁNYI ÉS INFORMATIKAI KAR ALKALMAZOTT ÉS KÖRNYEZETI KÉMIAI TANSZÉK

SZEGED 


\section{TÉMAVEZETŐ \\ DR. KUKOVECZ ÁKOS \\ egyetemi docens}




\section{Tartalom}

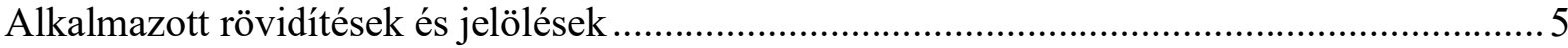

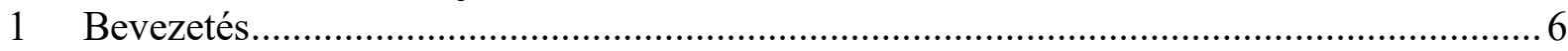

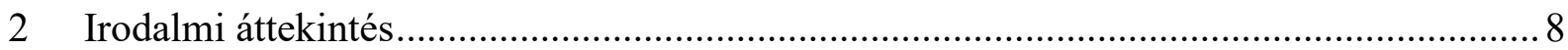

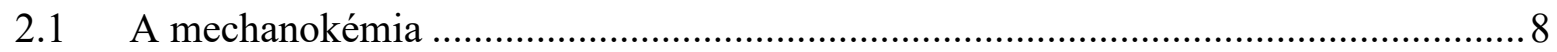

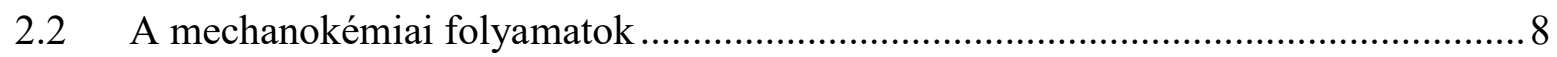

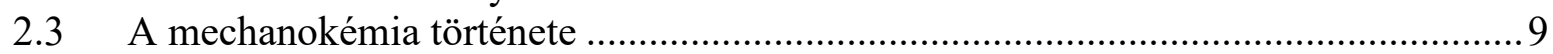

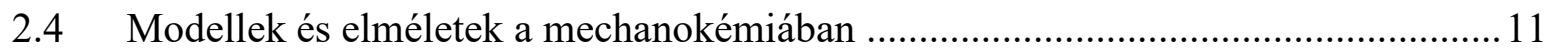

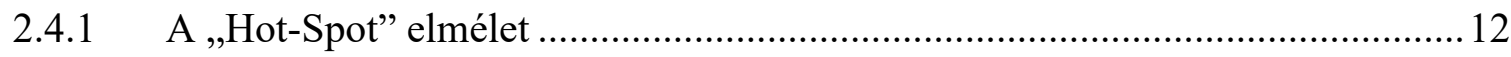

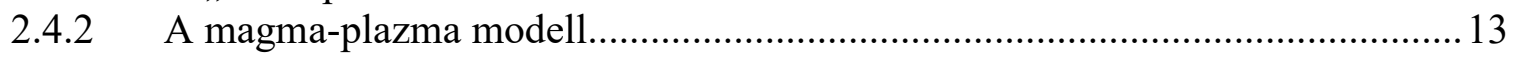

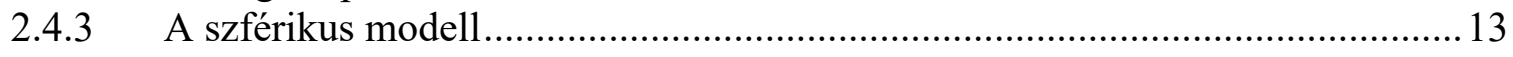

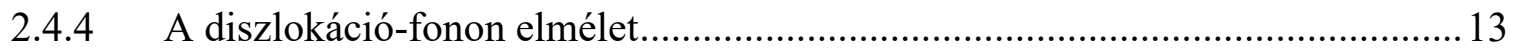

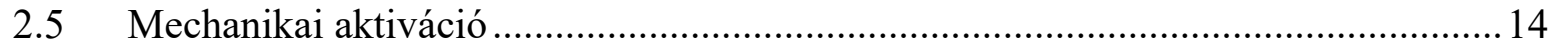

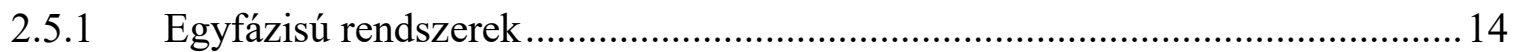

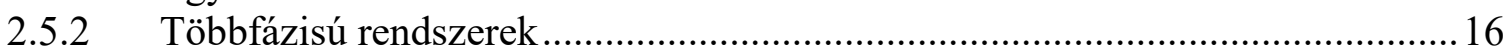

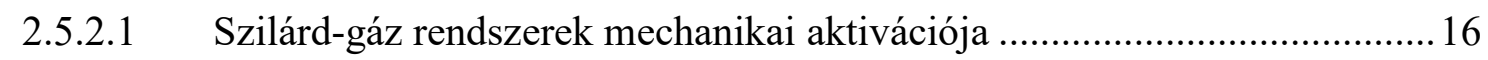

2.5.2.2 Szilárd-folyadék rendszerek mechanikai aktivációja .............................. 16

2.5.2.3 Szilárd-szilárd rendszerek mechanikai aktivációja .................................. 17

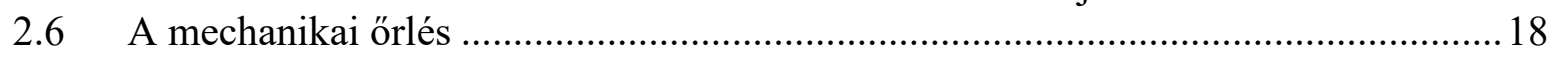

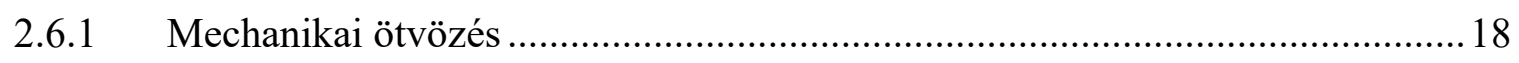

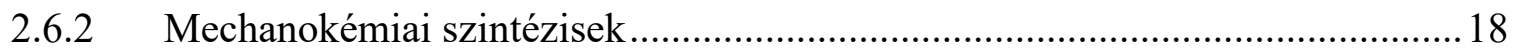

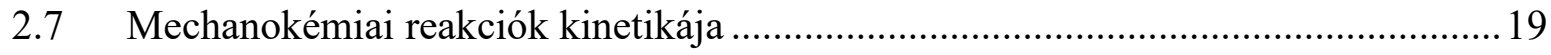

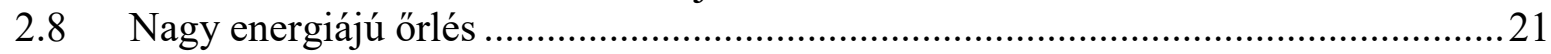

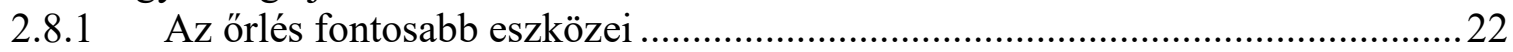

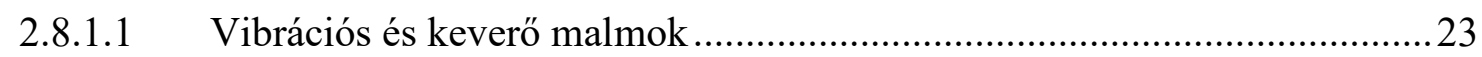

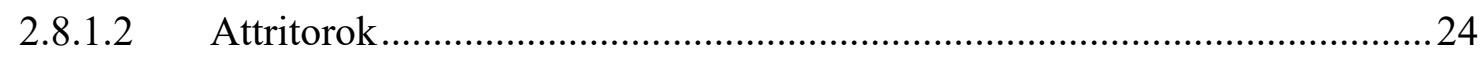

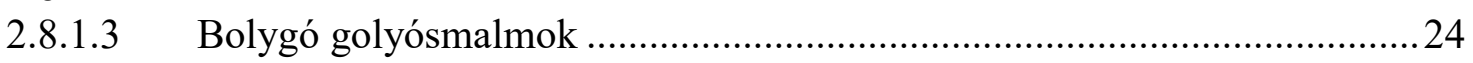

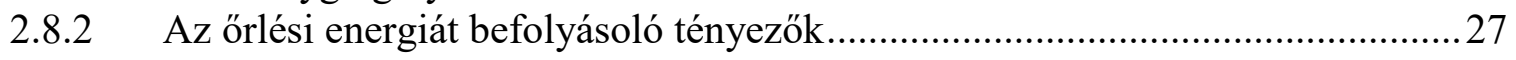

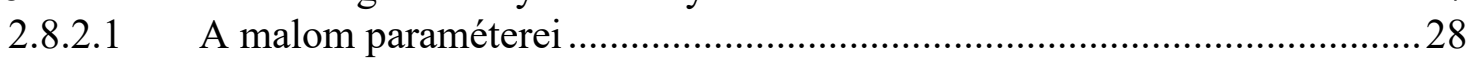

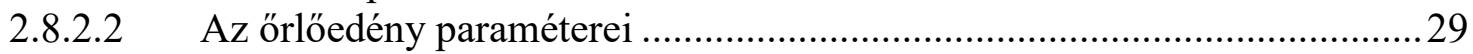

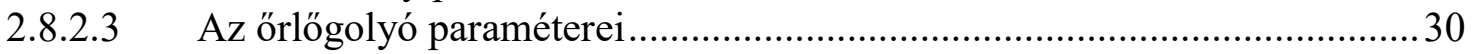

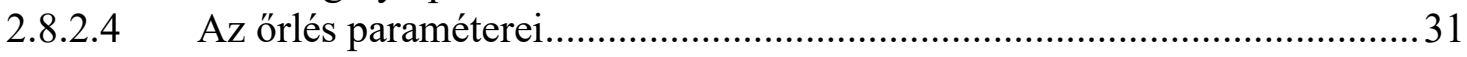

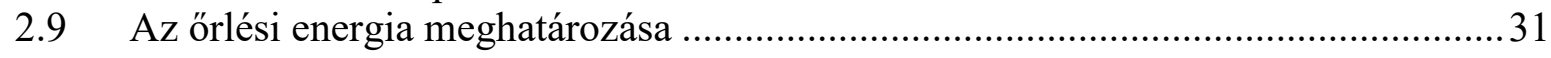

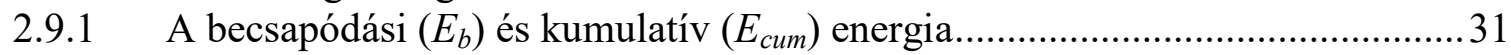

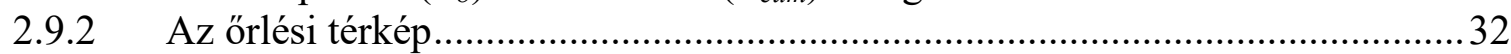

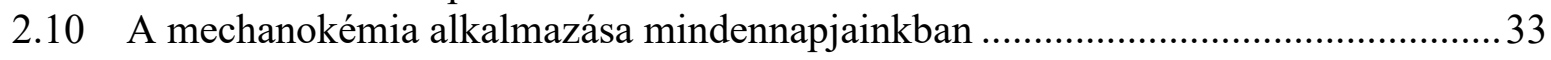

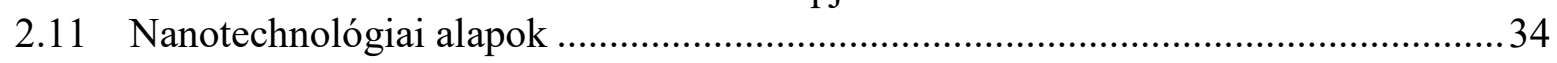

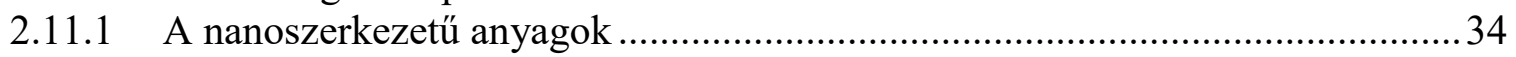

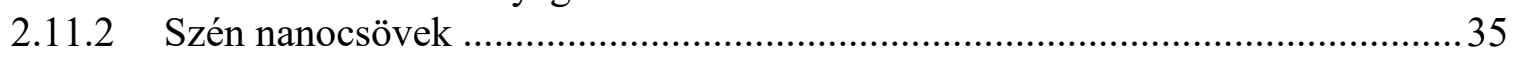

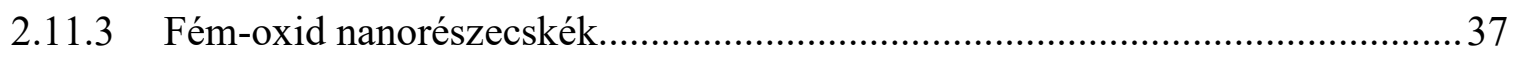

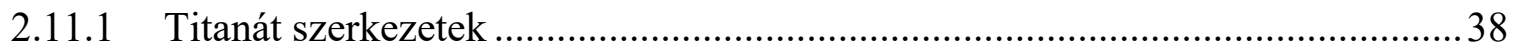

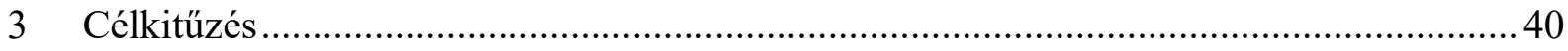

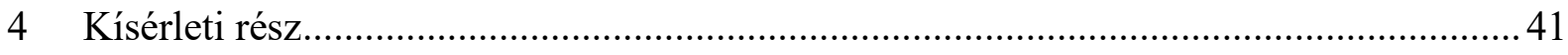

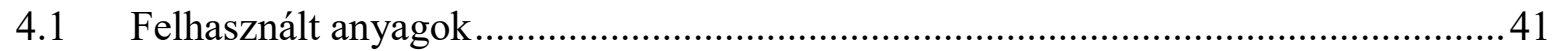

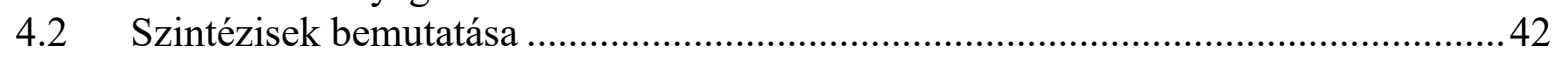

4.2.1 A Fritsch Pulverisette 6 (FP6) bolygó golyósmalom és a GTM-II rendszer...... 42

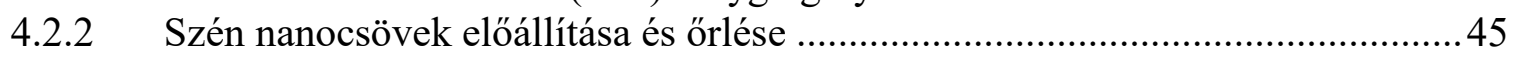

4.2.3 Fém-oxid nanorészecskék elöállítása ......................................................... 46 
4.2.3.1 Egyszerü fém-oxid nanorészecskék előállítása .........................................46

4.2.3.2 A nikkel-ferrit nanorészecskék előállítása ................................................ 47

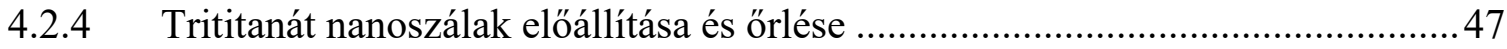

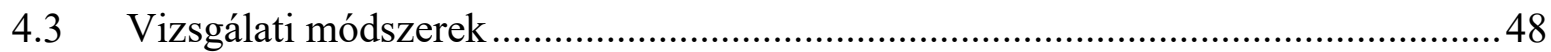

4.3.1 Transzmissziós elektronmikroszkópia (TEM) és elektrondiffrakció (ED) .........48

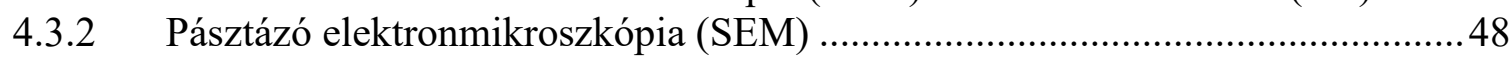

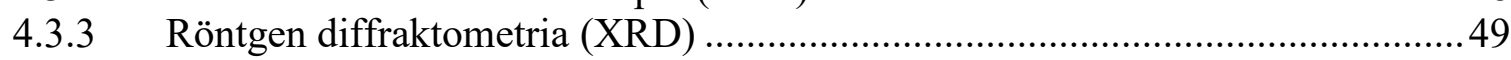

4.3.4 Fajlagos felület és pórusméret-eloszlás meghatározása ...................................49

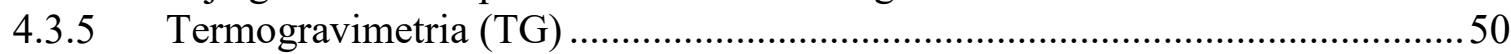

4.3.6 Fourier-transzfromációs infravörös spektroszkópia (FT-IR) ...........................50

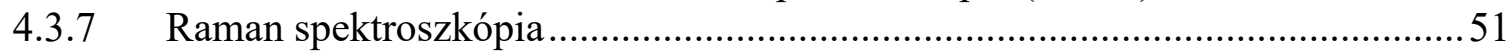

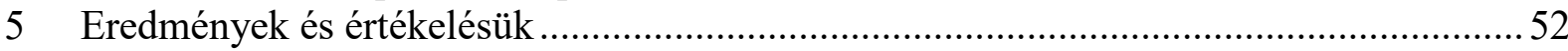

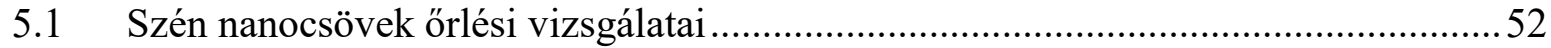

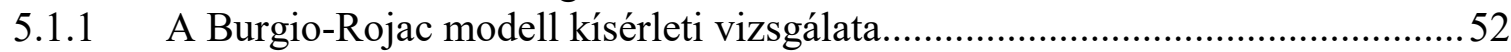

5.1.1.1 Az alaplemez fordulatszámának hatása .....................................................5

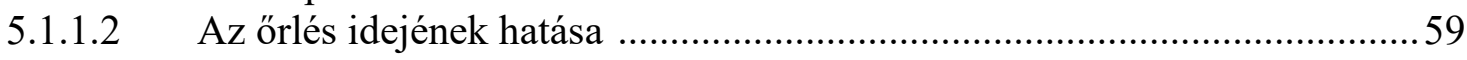

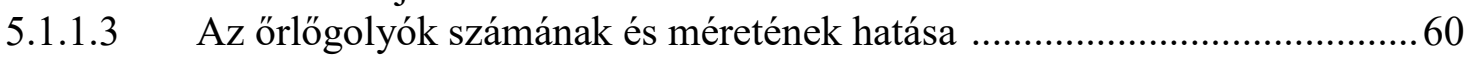

5.1.2 Az őrlési paraméterek hatásainak vizsgálata Raman spektroszkópiával............63

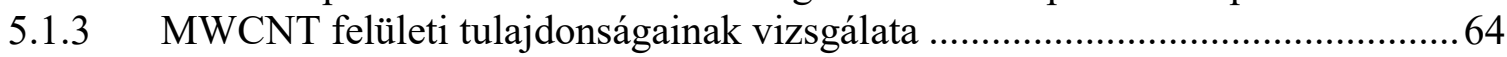

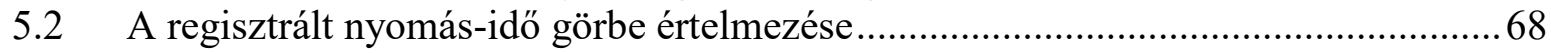

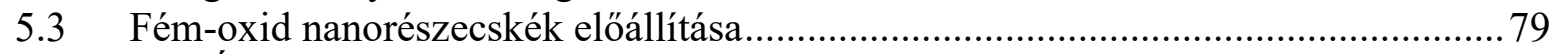

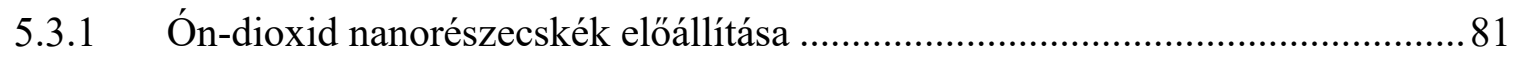

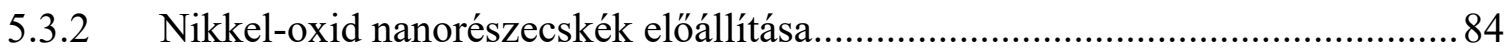

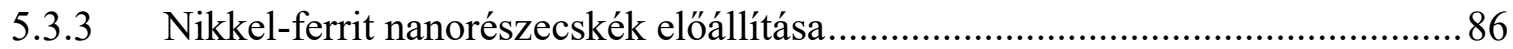

5.4 Mechanokémiailag előidézett fázisátalakulások vizsgálatai.................................... 88

5.4.1 Titán-dioxid nanorészecskék előállítása mechanokémiával ................................. 88

5.4.2 Trititanát nanoszálak szerkezetváltozása örlés hatására ......................................92

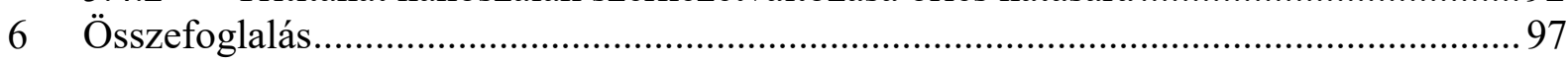

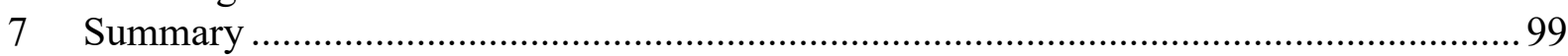

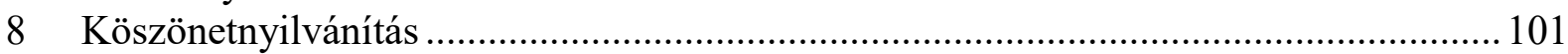

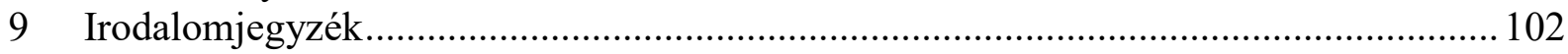




\section{Alkalmazott rövidítések és jelölések}

\section{Rövidités}

As

BET

CNT

$\mathbf{d}_{\mathrm{b}}$

DTA

$\mathbf{d}_{\mathbf{v}}$

$\mathbf{E}_{\mathbf{b}}$

$E_{\text {cum }}$

ED

FP6

FT-IR

GTM

$\mathbf{h}_{\mathbf{v}}$

$\mathbf{i}_{\text {rel }}$

I

$\mathbf{m}_{\mathbf{b}}$

$\mathbf{m}_{p}$

MWCNT

$\mathbf{N}_{\mathbf{b}}$

$\mathbf{r}_{\mathrm{m}}$

$\mathbf{r}_{\mathbf{p}}$

SEM

t

T

t.e.

TEM

TGA

TiONP

TiONT

TiONW

UV-Vis

$\mathbf{V}_{\mathbf{v}}$

XRD

$\rho_{b}$

$\rho_{\mathrm{v}}$

$\omega_{\mathrm{d}}$

$\omega_{\mathrm{v}}$
Eredeti forrás

Specific Surface Area

Brunauer-Emmett-Teller

Carbon NanoTube

Diameter of the Ball

Differential Thermal Analysis

Diameter of the Vial

Ball-impact Energy

Cumulative Energy

Electron Diffraction

Fritsch Pulverisette 6

Fourier Transform Infrared Spectroscopy

Gas Pressure and Temperature Measuring System

Height of the Vial

Gear ratio

Length

Mass of the Ball

Mass of the Powder

Multi-Walled Carbon Nanotube

Number of Balls

Radius of the Milling disk

Radius of the vial

Scanning Electron Microscopy Time

Temperature

(a.u. arbitrary unit)

Transmission Electron Microscopy

ThermoGravimetric Analysis

Titanium(IV)-Oxide Nanoparticle

Trititanate Nanotube

Trititanate Nanowire

UltraViolet-Visible spectroscopy

Volume of the vial

X-Ray Diffraction

Density of the ball

Density of the vial

Rotational speed of the disk

Rotational speed of the vial
Magyar megfelelö

Fajlagos felület

Brunauer-Emmett-Teller

Szén nanocső

Örlőgolyó átmérője

Differenciális termoanalízis

Örlőtégely átmérője

Becsapódási/beütési energia

Kumulatív energia

Elektrondiffrakció

FP6 bolygó golyósmalom

Fourier-transzformációs infravörös spektroszkópia

Gáznyomás és hőmérsékletmérő rendszer

Örlőtégely magassága

Áttétel (az őrlőtégely és alaplemez között)

Hossz

Örlőgolyó tömege

Örlemény tömege

Többfalú szén nanocső

Örlőgolyók száma

Alaplemez sugara

Örlőtégely és alaplemez tengelyeinek távolsága

Pásztázó elektronmikroszkópia Idő

Hőmérséklet

Tetszőleges egység

Transzmissziós elektronmikroszkópia

Termogravimetria

Titán-dioxid nanorészecske

Trititanát nanocső

Trititanát nanoszál

Ultraibolya-látható spektroszkópia

Örlőtégely térfogata

Röntgen diffraktometria

Örlőgolyó sürüsége

Örlőtégely sűrüsége

Alaplemez forgási sebessége

Örlőtégely forgási sebessége 


\section{Bevezetés}

A környezetvédelem központú iparágak számára kiemelt fontosságú az olyan új anyagok előállítása, melyek hatékonysága megközelíti vagy akár túl is teljesíti a múltban használt társaikét. Erre jelenthetnek megoldást a nanotechnológiával előállítható anyagok. Az elmúlt évtizedekben ugrásszerüen megnőtt az olyan technikák száma, melyek által ugyanazon anyag más-más szerkezetü, méretű vagy morfológiájú változatai hozhatóak létre (pl.: különböző titanát szerkezetek előállítási lehetőségei). A „nano-” prefixum alkalmazása technológiai szempontból azt feltételezi, hogy az anyagunk legalább egy jellemző mérete az 1-100 nm közti tartományba esik, és ebből adódóan fizikai-kémiai tulajdonságai különböznek tömbi fázisú formájukhoz képest. Ez általában a felületi atomok arányának ugrásszerü emelkedésével és az elektronszerkezet megváltozásával magyarázható. Annak ellenére, hogy a mechanokémia nem a nanotechnológia legszélesebb körben alkalmazott szintézismódszere, már régóta alkalmas nanoméretủ anyagok előállítására.

A malmok a mechanokémia legismertebb eszközei. Ez annak is köszönhető, hogy laboratóriumi méretben viszonylag egyszerü berendezések és egyszerre nagyobb mennyiségü minta gyártására is képesek. A malmok tehát nem csak a poranyagok/keverékek őrlésére szolgálnak (pl.: nyersmalmok), hanem új anyagok szintézisére is alkalmasak. Az elöre megtervezett tulajdonságokkal rendelkező anyagok előállításához azonban elengedhetetlen az őrlési folyamatok precíz szabályozása, mivel csak így várható el, hogy megfelelő terméket állítsunk elő. Az általunk használt bolygó golyósmalmot (mely elnevezés az őrlőedény kéttengelyü, bolygószerü mozgására utal) kifejezetten erre a célra fejlesztették ki, s így a mechanokémiai kutatások egyik alapeszközévé vált. Sok kutatócsoport dolgozott és dolgozik ma is a bolygó golyósmalmokban előállítható nanoszerkezetek számának bővítésén és a folyamatok kinetikájának értelmezésén, modellezésén.

A nanoméretű anyagok sokat vizsgált csoportja a félvezető, illetve szigetelő kerámiák. Előzőek az elektronikában (napelemek, üzemanyagcellák, kijelzők), illetve gázszenzorként is felhasznált anyagok, míg utóbbiak nagy kémiai- és hőstabilitásuk miatt kiváló szigetelők. A kutatásokat nagyban segíti ezeknek az anyagoknak a nagy mennyiségben történő előállítása valamely könnyen reprodukálható módszerrel, erre pedig a mechanokémia kiválóan alkalmas.

Napjainkban a nanoszerkezetű anyagok legkiemelkedőbb képviselői képesek különböző struktúrákat felvenni, ami más és más területen teszik őket felhasználhatóvá. Erre talán 
legjobb példa a szén allotróp módosulatai (gyémánt, grafit, fullerének, amorf szén, egy- és többfalú szén nanocsövek). Tömeges előállításukhoz és ipari mennyiségben történő alkalmazásukhoz szükség van kémiai és fizikai tulajdonságaik vizsgálatára. Ha képesek vagyunk az őrlés közben a malom által az anyaggal közölt energiát számszerűsíteni, úgy az őrlemény állapotváltozásaihoz fizikai paramétereket tudunk hozzárendelni. Ez elvezethet oda, hogy előre megtervezett struktúrájú terméket gyárthassunk. Mindehhez szükséges az örlési folyamat minél több paraméterének vizsgálata, ami összetett és időigényes folyamat.

Doktori munkám során vizsgáltuk az őrlés eszközeinek (pl.: őrlőedény, őrlőgolyók), illetve a malom egyes paramétereinek (pl.: fordulatszám), hatását a termék minőségére. Ehhez egyrészt többfalú szén nanocsövet öröltünk, és mértük a bizonyos tulajdonságaikban bekövetkező változásokat (darabolódás, amorfizáció, fajlagos felület stb.). Másrészt egy már létező, az őrlés során egy golyó által az őrleménynek átadott energia számítására képes egyenlettel számoltuk az egyes paraméter együttesekhez tartozó energiaértékeket. Ugyanezt titanát nanoszerkezetek őrlésére is megtettük. Elvégeztük egyes fém-oxid nanorészecskék mechanokémiai szintézisének optimalizálását, valamint vizsgáltuk a reakciók kinetikáját is.

Összefoglalva elmondható, hogy doktori munkám során elméleti megfontolások és kísérleti eredmények kombinálásával kidolgoztunk és részletesen megvizsgáltunk egy olyan mechanokémiai keretrendszert, amellyel számos nanorészecske előállítható. Disszertációmban először áttekintem a téma megértéséhez szükséges irodalmi hátteret, majd a kísérleti eszközök és módszerek bemutatása után részletezem saját eredményeimet. 


\section{Irodalmi áttekintés}

\subsection{A mechanokémia}

Mechanokémiáról beszélünk, amikor egy vagy több anyag kinetikai energiaközlés hatására elbomlik vagy szerkezete átalakul. A klasszikus értelemben vett mechanokémia tárgykörét kizárólag azok a reakciók képezik, amelyek a fent említett kinetikai energia nélkül nem játszódnak le, tehát a fizikai behatás szolgáltatja az aktiválási energiájukat. Ez leggyakrabban szilárd anyagok között valósul meg, de van példa szilárd-folyadék ${ }^{1}$, illetve szilárd-gáz reakciókra is. A tágabb értelemben vett mechanokémia részét képezik azok a folyamatok is, amelyek idővel maguktól is lejátszódnának, de a befektetett munka eredményeként a reakciósebességük megnő, illetve a termékük valamely jellemzőjében jelentősen eltér a mechanikai hatás mentes átalakulásétól (pl.: nanokristályos anyagok előállítása mechanokémiával).

\subsection{A mechanokémiai folyamatok}

Az egyensúlyi állapothoz képest többletenergiával rendelkező anyag metastabil állapotban van. A mechanokémia célja ennek az állapotnak az elérése, amely vonatkozhat:

- szerkezetre; ekkor a rendszer termodinamikailag instabil állapotban van, így kötésrendszere megváltozhat úgy, hogy egy stabil állapotból a metastabil állapoton keresztül egy stabilba megy át (pl. $\mathrm{TiO}_{2}$ átkristályosítása), vagy egyszerüen elbomlik. ${ }^{2}$

- összetételre; amikor egy anyag (oldat) többletenergiája révén egy másik anyagot „beoldva” egyensúlyi állapotához képest túltelített lesz. ${ }^{3}$

- morfológiai állapotra; amikor az anyagban (többnyire annak felületén) nagyszámú diszlokáció és megnövekedett határfelület alakul ki. A mechanikai őrlés során ez utóbbi okozza a fokozott reakciókészséget.

A mechanikai őrlés több elnevezése is él az angol szakirodalomban (melyet a magyar nómenklatúra is átvett). Egyfázisú anyagoknál általában az $\mathrm{MM}$ - mechanical milling kifejezést használjuk, melynek magyar megfelelöje az egyszerü őrlés, míg az angol MG mechanical grinding-et a magyar zúzásnak fordítja. Többfázisú anyagok, és általában nagy energiájú őrlések esetén az MA - mechanical alloying, azaz mechanikai ötvözés használatos. Míg a köznyelvben az ötvözés föleg a fémeknél alkalmazott müveletet jelenti, addig a 
mechanokémia esetében a különböző szerves, illetve szervetlen vegyületek őrléssel elöidézett reakcióival is foglalkozik. ${ }^{4}$

\subsection{A mechanokémia története}

Jelenlegi forrásaink szerint a legkorábban leírt mechanokémiai reakció i.e. 4. századból származik, melyben egy réz mozsárban cinnabarit kristályból elemi higanyt állítottak elő ecetsavas közegben (1). A leírás Theophrastus-tól (i.e. 371 - i.e. 287) ered és a „De Lapidibus”, azaz „A kövekről” című tudományos művében szerepel. ${ }^{5}$

$$
\mathrm{HgS}+\mathrm{Cu} \rightarrow \mathrm{Hg}+\mathrm{CuS}
$$

Egy másik korai bejegyzés Arisztotelészt (i.e. 384 - i.e. 322) idézi, aki szerint „Oldószer nélkül nem játszódnak le reakciók”. Ez a kijelentés természetesen ellentmond az oldószermentes mechanokémiai reakciók létezésének, ugyanakkor felvetette annak lehetőségét, hogy a későbbiekben éppen ennek a „problémának” a megoldásán fáradozzanak a kutatók. A középkorban - ha még nem is mindig mechanokémia néven - számos területen alkalmazták a mechanikai energiaközléses anyagátalakítás technikáját, így például a kohászatban és a bányászatban is.

Faraday (1791-1867) figyelte meg, hogy egyes hidratált sók mechanikai hatásra maguktól dehidratálódnak. Egy 1827-ben kiadott könyvében mintegy 20 oldalt szentelt a különböző mozsarak és az általuk kivitelezhető aprítás elméleti alapjainak leírására. ${ }^{6}$ Legközvetlenebb mechanokémiai munkássága mégis az ezüst-kloridból történő elemi ezüst előállítása volt 1820-ban (2). ${ }^{7}$

$$
2 \mathrm{AgCl}+\mathrm{Zn} \rightarrow 2 \mathrm{Ag}+\mathrm{ZnCl}_{2}
$$

Az eljáráshoz dörzsmozsaras őrlést alkalmazott. Az ezüst mellett sikeresen végezte el a fenti kísérletet ón, réz és vas fémekkel is. Faraday tanulmányában azt is leírta, hogy a reakció gyors és erősen exoterm: ez rávilágított a mechanikai úton indukált önfenntartó reakciók lehetőségére.

Faraday tagadhatatlanul fontos munkássága ellenére az „első mechanokémikus” címet mégis M. Carey Lea (1823-1897) érdemli ki. Ö az általa három ezüst allotrópnak nevezett „oldható ezüst”, „oldhatatlan ezüst” és ,réz-színű ezüst” előállításán fáradozott. ${ }^{8,}{ }^{9}$ Ez vezette el az ezüst, higany, platina és arany halidjainak vizsgálatához. Első megfigyelése az $\mathrm{AgCl}$ 
szokatlan viselkedése volt energiaközlés hatására. Ha csak hevítette az AgCl-t, az megolvadt, míg csekély mechanikai stressz hatására elemi ezüstre bomlott el (3). ${ }^{10}$

$$
2 \mathrm{AgCl} \rightarrow 2 \mathrm{Ag}+\mathrm{Cl}_{2}
$$

Hasonló jelenséget figyelt meg $\mathrm{Hg}_{2} \mathrm{Cl}_{2}$ esetén is. $383{ }^{\circ} \mathrm{C}$ felett az anyag szublimált, míg nyomás alatt elemi higany keletkezett (4). ${ }^{11}$

$$
\mathrm{Hg}_{2} \mathrm{Cl}_{2} \rightarrow 2 \mathrm{Hg}+\mathrm{Cl}_{2}
$$

A mechanokémia történetével foglakozó Takács László a fenti két példát nevezi az első ténylegesen mechanokémiai reakcióknak, mivel ekkor alkalmazott valaki először szándékosan mechanikai energiaközlést abból a célból, hogy új terméket kapjon. ${ }^{12}$

Leslie H. Parker építette meg 1914-ben az első kutatási célú malmot, ami lényegében egy egyszerü mozsár volt egy exszikkátorba építve. A vizsgált reakció $\mathrm{Na}_{2} \mathrm{CO}_{3}$ és $\mathrm{BaSO}_{4}$ között játszódott le (5):

$$
\mathrm{Na}_{2} \mathrm{CO}_{3}+\mathrm{BaSO}_{4} \rightarrow \mathrm{Na}_{2} \mathrm{SO}_{4}+\mathrm{BaCO}_{3}
$$

A reakció lassan zajlik, fél óra örlés után a $\mathrm{Na}_{2} \mathrm{CO}_{3}$ mindössze $3 \%$-a alakult át, de Parker képes volt megfelelő körülmények között sikeresen növelni a rendszer hatékonyságát a nyírási feszültég növelésével anélkül, hogy fütötte volna a rendszert. ${ }^{13}$ Bebizonyította, hogy az a nyírófeszültség, ami a mozsár és a forgó őrlőkar között jön létre, nem egyenértékü az anyagra ható nyomás egyszerü növelésével elérhető energiaközléssel.

A két világháború alatt a mechanokémiával foglalkozó kutatók figyelme érthető okokból föként a robbanóanyagok felé fordult Oroszországban, Angliában és Franciaországban. ${ }^{14-16}$ Ezek a fejlesztések vezettek a „Hot-Spot” elmélet kidolgozásához, amely F.P. Bowden (1903-1968), D. Tabor (1913-2005) és A.D. Yoffe (1919-) munkájához füződik, s ami az első elméleti modellt jelentette a mechanokémiai folyamatokra. Később az alapelmélet számos kiegészítésen esett át és újabbak alapjául is szolgált (lásd. 2.4 fejezet). Az 1920-as években Tammann (1861-1938) arra a megállapításra jutott, hogy a mechanikai munka által átadott energia 5-15\%-a elraktározódik az őrölt anyagban (az ő esetében fém részecskékben), ami növeli annak reaktivitását. ${ }^{17}$ Munkatársaival $\mathrm{Na}_{2} \mathrm{CO}_{3}$ és $\mathrm{SiO}_{2}$ együttőrlésével $\mathrm{Na}_{2} \mathrm{SiO}_{3}$-t állított elö (6):

$$
\mathrm{Na}_{2} \mathrm{CO}_{3}+\mathrm{SiO}_{2} \rightarrow \mathrm{Na}_{2} \mathrm{SiO}_{3}+\mathrm{CO}_{2}
$$


Arisztotelész egykori kijelentése, mely szerint szilárd anyagok közt nem játszódhat le reakció megfelelő közeg nélkül, végleg megdőlni látszott. A mechanokémia a szerves anyagok terén is kezdett kibontakozni. A papíripar számára fontos eljárást dolgoztak ki annak a felfedezésnek az alapján, hogy a cellulózt megőrölve annak oldhatósága javítható. Ez a makromolekulák tördelésével, valamint hidrofil funkciós csoportok beépülésével magyarázható. ${ }^{18}$

Fink, Bowden és Tabor újabb fontos felfedezéseket tettek, miközben különböző fémek oxidációs és bomlási reakcióit, valamint a csúszási és gördülési súrlódást vizsgálták. Megfigyelték, hogy a gördülési súrlódás következtében a csapágy vasgolyóin feketés bevonat keletkezik akár pár perc alatt, amihez normális körülmények közt nagyon hosszú időre lenne szükség. A kísérletet megismételték acéllal, tiszta nikkellel és rézzel is. Közleményükben leírták, hogy a súrlódásnak kitett felületen több mint $700{ }^{\circ} \mathrm{C}$ hömérsékletet mértek, igaz ez nagyon rövid ideig, mindössze $10^{-4}-10^{-3}$ másodpercig tartott. ${ }^{19},{ }^{20},{ }^{21} \mathrm{Ez}$ a többletenergia kizárólag a mechanikai behatásból származhatott és ez okozta a fémek fizikai-kémiai átalakulását.

Mindezek után a mechanokémia már felkapott kutatási területnek számított és számos egyetemen alakult kutatócsoport a témában. 1962-ben megtartották az első mechanokémiát szorosan érintő konferenciát Németországban „1st European Symposium on Size Reduction” néven, majd 1993-tól az INCOME (International Conference on Mechanochemistry and Mechanical Alloying) vált a legjelentősebb fórummá. ${ }^{22}$

\subsection{Modellek és elméletek a mechanokémiában}

A kérdésre, hogy az anyagok miért alakulnak át mechanikai hatásra, számos elmélet és modell született. Kézenfekvő volt, hogy a súrlódásból eredő többletenergia az, ami az anyagokat reaktív állapotba hozza, hasonlóan az egyszerü hevítéshez. Ugyanakkor ez a jelenség korántsem olyan szembetűnő, mint amikor például két olvadék fémből valamilyen ötvözetet hozunk létre. Minden elmélet egyetért abban, hogy a reaktív állapot időben és térben is csekély kiterjedésű, így kimutatása komoly fizikai-kémiai analízist igényel. Összhangban a müszerek fejlődésével, a hipotézisekből lassan bizonyított elméletek és pontosabb modellek születtek. 


\subsubsection{A „Hot-Spot” elmélet}

A „Hot-Spot” vagy „Forró pont” elmélet a már korábban említett Bowden, Yoffe és Tabor kutatóhármas munkája alapján született meg (2.1. ábra). Ök általánosan azt találták, hogy a többletenergiát hordozó terület mintegy $1 \mu \mathrm{m}^{2}$ kiterjedésű, $1000{ }^{\circ} \mathrm{C}$ hőmérsékletű és hozzávetőleg $10^{-4}-10^{-3}$ másodpercig tartja meg ezt az állapotot. ${ }^{14-16}$ Ezt alátámasztó eredményeket kapott törési vonalakon felszabaduló hőmérséklet vizsgálatakor Weichert és Schönert is 1974-ben. ${ }^{23}$ Kísérleteikben a törési felület növekedési sebességének emelésével egyre nagyobb mennyiségü felszabaduló energiát mértek. Ennek bizonyítására Fox és társai létrehoztak egy olyan tömegspektrométerrel összekötött berendezést, amelyben lehetőség nyílt kristályok (pl.: kalcit, ólom-azid, magnezit) törésére, így a keletkező gázokat analizálni tudták. $^{24}$ A szilárd anyagokból felszabaduló gázok detektálásával igazolták a magas hőmérsékletü pontok létezését.

A „Hot-Spot” elmélet szerint a többletenergia a robbanószerek láncreakciójához hasonlóan biztosítja a további átalakulásokhoz szükséges energiát. Később bebizonyosodott, hogy habár a kimutatott hőmérséklet valóban elegendő lenne a láncreakció táplálására, a forró pont olyan csekély ideig létezik (még kevesebb ideig, mint azt Bowden gondolta), hogy a külső hatás megszüntetésével a reakció is leáll, hacsak kémiai energia felszabadulása nem táplálja azt. ${ }^{25,26}$

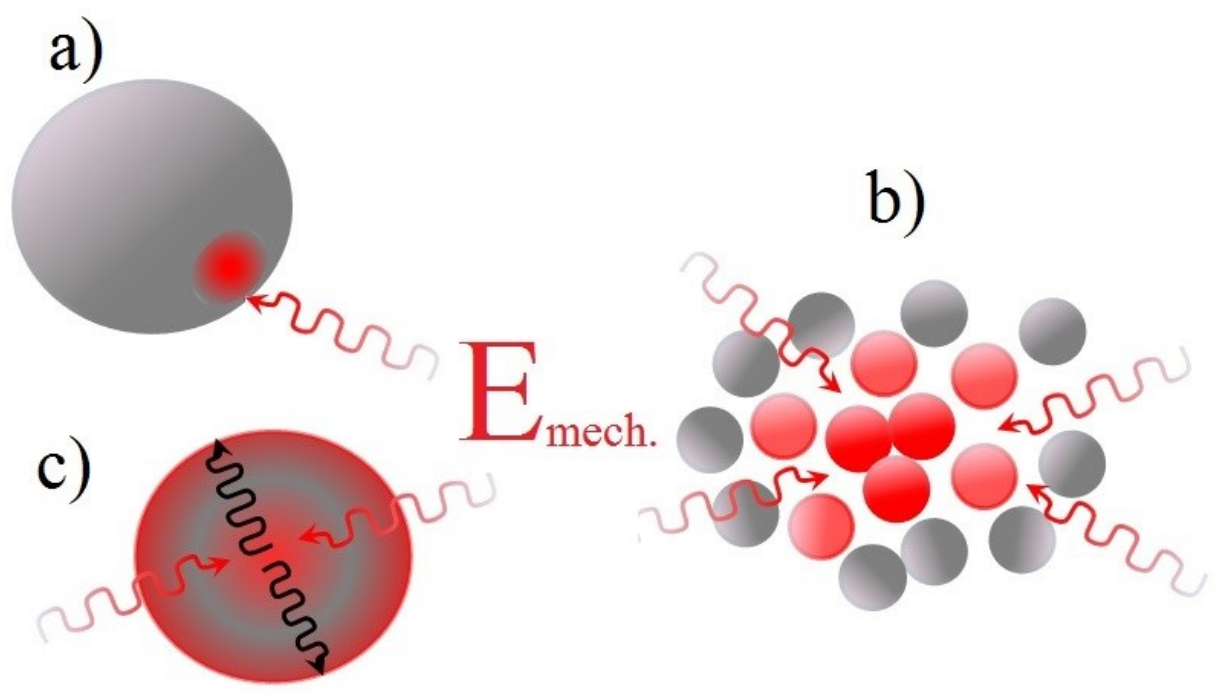

2.1. ábra: a mechanikai energia által gerjesztett aktivált állapotok: a) „Hot-spot” elmélet; b) magma-plazma és szférikus modell; c) diszlokáció-fonon modell. 


\subsubsection{A magma-plazma modell}

A modell Thiessen és társai munkájához kapcsolódik. Elméletük szerint a szilárd anyagok ütközésekor nagyon nagy mennyiségü energia szabadul fel (2.1. ábra). Ez plazmaállapotot hoz létre, ami elektronok, fotonok és apró szilárd részecskék emisszióját eredményezi. Maga a plazmaállapot amellett, hogy nagyon rövid életü, elérheti a $10000{ }^{\circ} \mathrm{C}$ hőmérsékletet is. ${ }^{27}$ Thiessen megkülönbözteti a becsapódás közben, a gerjesztett állapotban és a közvetlenül azután zajló reakciókat. Továbbfejlesztve elméletét más kutatókkal közösen leírták a „mechanikai energia indukálta” állapotokat, melyek főként élettartamukban különböznek. $^{28}$ Így míg maga a becsapódás $10^{-6} \mathrm{~s}$-ig, a plazmaállapot pedig $10^{-7} \mathrm{~s}$-ig tart, addig egyes folyamatok, így a tribolumineszcencia (mechanikai hatásra bekövetkező fényemisszió), a rácshibák megjelenése vagy az exoelektronok (exoterm folyamatokban kilépő, hozzávetőleg $1 \mathrm{eV}$ energiájú elektronok) emissziója $10^{-7}-10^{5} \mathrm{~s}$ között nagyon változó élettartamúak lehetnek.

\subsubsection{A szférikus modell}

Thiessen egy 1983-as konferencián mutatta be újabb elméletét. Rámutatott, hogy az ütés okozta stressz több különböző formában is megjelenhet, tehát nem jellemezhető egyetlen állapottal. Ezt a „halmazt” triboplazmának ${ }^{29}$ nevezte, ami lényegében a mechanikai behatás következtében többletenergiával bíró anyagrész, melyben a magma-plazma modellnél már leírt folyamatok figyelhetők meg. Ami továbbra sem változott a korábbi elméletekhez képest, az a gerjesztett terület kis kiterjedése és rövid élettartama. A triboplazmában az átalakulások sztochasztikus jellegüek. Az egyes „,plazmaállapotok” éles határ nélkül követik egymást. A lényeges különbség a korábbi magma-plazma modellhez képest az, hogy az energiatöbblettel rendelkező anyagrész nem korlátozódik a becsapódás pontjára, hanem annak környezetében megoszlik. A szomszédos területek ,összeolvadásával” tehát a triboplazma kiterjedhet. ${ }^{30}$

\subsubsection{A diszlokáció-fonon elmélet}

A diszlokáció-fonon elmélet szerint a mechanikai aktiváció hatására a kristályszerkezetben diszlokációk keletkeznek, melyek a felületen „felhalmozódva” okozzák a megnövekedett reaktivitást ${ }^{31}$ (2.1. ábra). A diszlokációk mozgásából, azok kölcsönhatásaiból erednek a kémiai átalakulásokat közvetlenül indukáló fononok. A reakció tehát az ütés hatására létrejövő rendezetlenségre vezethető vissza. ${ }^{32}$ 


\subsection{Mechanikai aktiváció}

A mechanikai aktiváció fogalmát Smékal vezette be 1942-ben. Szerinte a mechanikai aktiváció az a folyamat, ami megnöveli egy anyag reakcióképességét úgy, hogy az kémiai szempontból változatlan marad. ${ }^{33}$ Ebből a szemszögből a mechanikai aktiváció kizárólag a reakciók aktiválási energiáját adja, és nincs hatással azok további alakulására. A későbbiekben a fogalom definíciója a szerzők által megfigyelt újabb folyamatok miatt változott.

A pontosítással Boldyrev foglalkozott, aki három átfogó tanulmányt írt a témában, igyekezve finomítani a mechanikai aktiváció definícióját. ${ }^{26,34,35}$ Ö a mechanikai aktivációt a következőkkel jellemzi: 1) az impulzus frekvenciája, ez a behatási zóna (stressz zóna) kialakulására és annak relaxációjára tagolható; 2) az ütközés hatása a szilárd felszínen (ami létrejöhet két részecske, vagy egy részecske és a mechanikai aktivációt közvetlenül kiváltó test ütközése révén). ${ }^{36-40}$ Tanulmányában meghatározta a mechanikai aktiváció során kialakuló stressz zóna méretét és élettartamát. ${ }^{41}$ Emellett relaxációs csatornákat azonosított, mint például a hömérsékletváltozás, átmenet különböző metastabilis állapotok között, vagy a felszín struktúrájának átszerveződése. ${ }^{42}$

A mechanikai aktiváció tovább csoportosítható aszerint, hogy egy vagy több fázis között zajlik-e, illetve a különböző fázisok összetétele szerint.

\subsubsection{Egyfázisú rendszerek}

Ha egyféle anyagot vetünk alá mechanikai kezelésnek, a relaxáció akkor is több, egymástól független módon játszódhat le, valamint számos másodlagos jelenség kísérheti azt (hőfelszabadulás, új határfelületek megjelenése, rácshibák kialakulása, polimorf állapot, amorfizáció, kémiai átalakulás). Ezek megoszlását az átadott energia mennyisége és a fizikai tulajdonságok határozzák meg. Néha az eredetileg preferált útvonal helyett egy másik veszi át a vezető szerepet: például szervetlen sók szilárd részecskéin kialakuló törési vonalak terjedési sebességének növekedésével a hőbomlást a mechanikai aprózódás váltja fel. ${ }^{43}, 44 \mathrm{~A}$ mechanikai hatásnak kitett részecskék méretének csökkenésével pedig a darabolódás helyett idővel a plasztikus deformáció lesz jellemző. ${ }^{45}, 46$ Ezekhez hasonló jelenségeket írt le M. Carey Lea már 1892-94 között. ${ }^{10,11}$ 


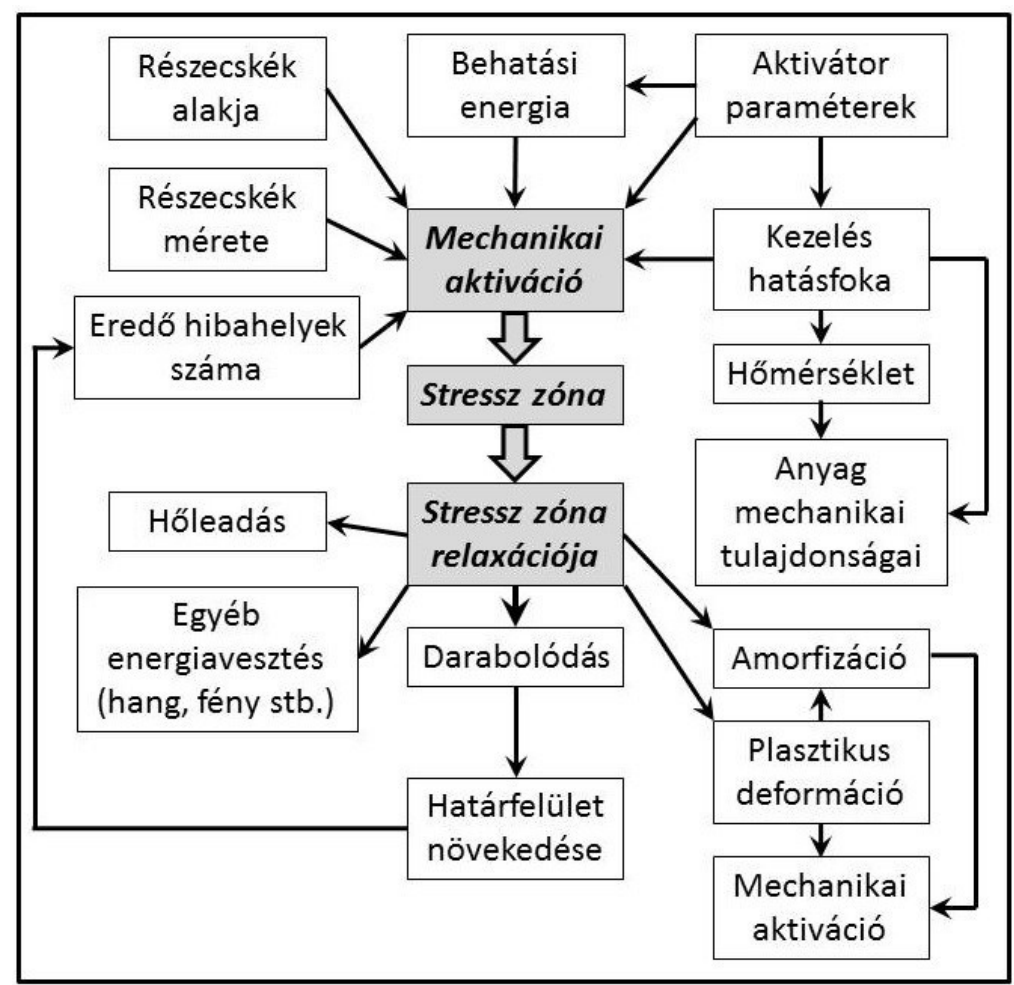

2.2. ábra: a mechanikai hatásra kialakuló aktivált állapot, mely a stressz zóna kialakulásához majd relaxációjához vezet, valamint az ezeket befolyásoló paraméterek és folyamatok.

A 2.2. ábrán figyelhetőek meg azok a paraméterek, melyek hozzájárulnak a mechanikai aktivációhoz, a stressz zóna kialakulásához és lehetséges relaxációs útvonalakat biztosítanak. A séma szigorú értelemben csak az egyfázisú rendszerekre igaz. Többfázisú rendszerek esetén a prekurzorok közti reakciók, a termékek rekombinációja és bomlása mind befolyásolják a rendszer pillanatnyi energiaszintjét (egy endoterm reakció például jelentős mennyiségü energiát vonhat el). Jól követhető a mechanikai kezelés célja: a lehető legnagyobb aktív felületet létrehozni. A felgyülemlő energiával felületi defektusokat, új szerkezetet alakíthatunk ki, így könnyebben elérhető az adott folyamat aktivációs energiája.

Amennyiben a mechanikai behatásra kialakuló stressz zóna relaxációja tovább tart, mint a lejátszandó reakció, az adott folyamat azonnal végbemegy. Általában ez jellemző a mechanokémiai folyamatokra. Ha viszont a relaxáció a gyorsabb, akkor mechanikai aktiválásról beszélünk. Ilyen például a $\mathrm{NaNbO}_{3}$ szintézise, amely során közel 10 óra őrlés után kezdődik csak el a prekurzorok $\left(\mathrm{Na}_{2} \mathrm{CO}_{3}\right.$ és $\left.\mathrm{Nb}_{2} \mathrm{O}_{5}\right)$ közti reakció. ${ }^{47}$ A felgyülemlő energia a legkülönbözőbb módokon „raktározódhat”. Defektusok által leggyakrabban rácshibák keletkeznek: diszlokációk, ion- és atomvakanciák, intersticiális és szubsztitúciós atomok. $^{46,48}$ 


\subsubsection{Többfázisú rendszerek}

\subsubsection{Szilárd-gáz rendszerek mechanikai aktivációja}

A mechanikai aktiváció hatással van mind a gázok szilárd felületeken történő adszorpciójára, mind az utána lejátszódó esetleges reakcióra. A kezelés hatására a gázmolekulák bejuthatnak a kristályrácsba, illetve megnőhet a határfelületek aktív centrumainak száma is. A mechanikai aktiváció idővel ugyan a deszorpciót segíti elő, de az aktív centrumok emelkedő száma az adszorpció lehetőségét növeli meg.

Reakció nem kizárólag szilárd anyag és gáz között játszódhat le, hanem a szilárd felületen két gázmolekula között is. ${ }^{49,}{ }^{50} \mathrm{Ez}$ vetette fel a mechanokémia katalízisben történő alkalmazásának lehetőségét. Fém és fémoxid katalizátorok mechanikai aktivációjával tovább lehet növelni azok hatékonyságát ${ }^{51-54}$, sőt egyes esetekben a konverzió mellett a szelektivitás is sikerrel javítható. ${ }^{55,} 56$ Szintén aktívan kutatott terület a fémek és fém-oxidok mechanokémiai hidrogénezése, karboxilezése vagy oxidációja. ${ }^{57}$

Termodinamikailag „tiltott” reakciók is lejátszódhatnak a mechanikailag aktivált környezetben, így sikerült például aranyat oxidálni szén-monoxiddal. ${ }^{53}$ A legígéretesebbnek mégis a fémek hidrogénezési reakciói mutatkoztak. Az első áttörést a mechanikailag aktivált magnézium hidrogénezése jelentette. ${ }^{58}$ Nikkel, vas és króm hozzáadásával a konverzió értéke drámaian megemelkedett. ${ }^{59}$ Mikor a kutatások az egész világra kiterjedtek, a jelenséget kipróbálták néhány klasszikus hidrogén adszorbensen annak reményében, hogy felfedeznek egy jól működő hidrogéntárolási technológiát. A mechanokémiával ötvözött FeTi, $\mathrm{LaNi}_{5}$ vagy $\mathrm{MgYNi}_{4}$ összetételü fémvegyületek kitűnő eredményeket hoztak ezen a területen. ${ }^{60-64}$

\subsubsection{Szilárd-folyadék rendszerek mechanikai aktivációja}

A szilárd-folyadék rendszerek mechanikai aktivációjának fontosságát hamar felismerték a kutatók, amihez az is hozzájárult, hogy alapvető ipari technológiák is alkalmazták. A hidrometallurgiában (fémek nedves úton való előállítása ércekből) a mechanikai aktiváció növeli a fémek kivonásának hatékonyságát és a rendszer szelektivitását. ${ }^{65}$, 66 A gyógyszeriparban ugyanezt az energiát a nehezen oldódó anyagok szolubilizálására fordítják. ${ }^{67,}{ }^{68}$ Az oldhatóság javításához a fajlagos felület növelése önmagában nem mindig elegendő. Mint korábban olvashattuk, a mechanikai aktiváció defektusokat hoz létre a szilárd 
testek felületén. A diszlokációk sürüsége kulcsfontosságú az oldhatóság növelésében, így kiemelt szerepe van a szilárd-folyadék reakciók esetén. ${ }^{69,70}$

Elegendően nagy mechanikai aktiváció mellett a körülmények megfelelhetnek akár a mechanikai bontással iniciált hidrotermális reakciók beindításához is. ${ }^{71}$ Egy kristály lebomlása nagyban függ a mechanikai aktiváció pontos hatásától. Általánosan azt lehet mondani, hogy az aktiválás a legtöbb kristály esetében polimorf átalakulást, illetve amorfizációt indukál. Habár a pontos hatásmechanizmus még nem ismert, annyi elmondható, hogy az átalakulás vagy intermedierektől függetlenül a felgyülemlett és kiterjedt defektusok által közvetlenül, vagy hő hatására olvadást követően újrakristályosodás által valósul meg. Természetesen ezek a hatások nem csak vizes közegben, hanem más szilárd-folyadék rendszerekben is lejátszódhatnak.

\subsubsection{Szilárd-szilárd rendszerek mechanikai aktivációja}

A szilárd anyagok közti reakciók nem a teljes térfogatban vagy az anyagok összfelületén zajlanak, hanem kizárólag azok közös érintkezési felületén, emiatt ennek nagysága döntően befolyásolja az egyes folyamatok sebességét. A kétfázisú rendszerek közül a szilárd-szilárd átalakulásokkal foglalkoznak a legszélesebb körben, ami főként a termelő technológiákban való alkalmazhatóságuknak köszönhető. Ezek az úgynevezett „szilárd eljárások" környezetbarát (oldószer- és adalékanyag-mentes) és költséghatékony alternatívát jelenthetnek számos ipari folyamatban. ${ }^{72}$

A szilárd-szilárd rendszerek területén az egyik legalapvetőbb alkalmazás a speciális ötvözetek előállítása. Mechanokémiai aktivációval lehetőség nyílik a határok kibővítésére azáltal, hogy egyes esetekben a termodinamikai egyensúlyi állapot helyett a számunkra kedvezőbb összetételü terméket hozhatunk létre. Például az alumínium maximális oldhatósága nikkelben $\quad 13,5$ at. $\% \quad 1000 \quad{ }^{\circ} \mathrm{C}$-on. $\quad$ Ez $500 \quad{ }^{\circ} \mathrm{C}$-on 10 at.\%-ra, míg szobahőmérsékleten 1 at.\% alá csökken. Ennek ellenére mechanokémiai módszerrel a 28 at.\% alumínium tartalom is elérhetô. ${ }^{73,74}$

Mivel doktori disszertációm témája szinte kizárólag a szilárd fázisú rendszerek őrlését taglalja, így az irodalmi bevezető további fejezetei az ehhez a részhez tartozó hátteret ismerteti. 


\subsection{A mechanikai őrlés}

\subsubsection{Mechanikai ötvözés}

Mechanikai ötvözésnél porok és porkeverékek száraz, illetve nedves örlésével hozunk létre valamilyen terméket. Ehhez használhatunk adalékanyagot vagy speciális atmoszférát is. Jellemzően egy kb. 10 mm átmérőjű őrlőgolyó és az edény fala, illetve egy másik golyó közé mintegy 1000 darab aggregátum ( 0,2 mg) csapdázódik egyetlen becsapódás alkalmával. Az aprózódás során egy bizonyos méret alatt már csak plasztikus deformációról beszélhetünk. Ekkor a részecskék akkora energiára tehetnek szert, hogy összeolvadjanak és ötvözeteket képezzenek. A folyamat mindemellett a részecskék növekedését is eredményezi (2.7 fejezet). Kock és társai megfigyelték, hogy ötvözött nanokristályos termékek esetén az elérhetö szemcseméret fordítottan arányos az anyag keménységével. ${ }^{75}$

Mechanikai ötvözéshez nem csak bolygó golyósmalmot, hanem lényegében bármilyen nagy energiájú őrlésre képes eszközt használhatunk. Mivel leggyakrabban valamilyen fém vagy fém-oxid porral dolgozunk, így főként nagy keménységü, például rozsdamentes acélból vagy volfrám-karbidból készült őrlőedényeket alkalmazunk.

\subsubsection{Mechanokémiai szintézisek}

Először az 1980-as években jelentek meg olyan közlemények, melyek már kifejezetten mechanokémiai úton szintetizált anyagokról számoltak be. ${ }^{76,77}$ Például CuO-ból állítottak elő elemi rezet úgy, hogy azt kalciummal örölték össze. ${ }^{77}$ Így a fém-oxidok redukciója vált a mechanokémia első elterjedt folyamatává, ami általánosan az alábbi egyenlettel írható le (7):

$$
M O+R \rightarrow M+R O
$$

Az egyenletben szereplö MO valamilyen fém-oxid, melyet egy nála reaktívabb fém $(\mathrm{R})$ redukál elemi fémmé $(\mathrm{M})$.

Később a mechanokémiai szintéziseket kiterjesztették a nemfémes vegyületekkel való vizsgálatokra is, mint például grafén előállítása nagy energiájú őrlés során. ${ }^{78} \mathrm{~A}$ mechanokémia tárgykörébe ma már nem csak azok a folyamatok tartoznak, amelyek kizárólag a mechanikai aktiválás során játszódnak le. Ha a reakció mechanikai aktiválás nélkül is lezajlana, de a közölt energia hatására az újonnan kialakuló termék valamilyen tulajdonságában változást figyelhetünk meg, akkor az átalakulást szintén a mechanokémiai folyamatok közé soroljuk. Erre nagyon jó példa a nanorészecskék előállítása, mivel 
mechanokémiai szintézisek során képesek vagyunk nanométeres tartományba eső terméket létrehozni. A következő, 2.7 fejezetben említést teszek az őrléssel megvalósítható méretcsökkentés határairól. Az elérhető legkisebb méret függ az anyagi minőségtől és a kiindulási anyag eredeti méreteitől, így őrléssel közvetlenül akár 10-100 nm nagyságrendü részecskéket is létre lehet hozni. Míg az aprítás során felülről lefelé végzünk méretcsökkentést, addig mechanikai szintézis esetén pont fordítva járunk el: az újonnan kialakuló nanokristályok növekedését akadályozzuk meg. Ez természetesen nem közvetlenül, hanem az anyagnak átadott mechanikai többletenergia hatására történhet meg. ${ }^{79}$ Így nagy energiájú őrléssel nanokristályokat hozhatunk létre. A mechanikai aktiváció energiájának nagysága megszabhatja továbbá a termék minőségét, ${ }^{80-83}$ így akár egy anyag több kristálymódosulata is létrehozható (polimorf anyagok). ${ }^{84,85}$

\subsection{Mechanokémiai reakciók kinetikája}

Egy mechanokémiai reakció általános kinetikai sémáját láthatjuk a 2.3. ábrán. ${ }^{30}$ Természetesen nem lehet az összes mechanikai energia hajtotta reakciót pontosan az alábbi ábrával magyarázni, de összességében jól mutatja a teljes folyamat lépéseit.

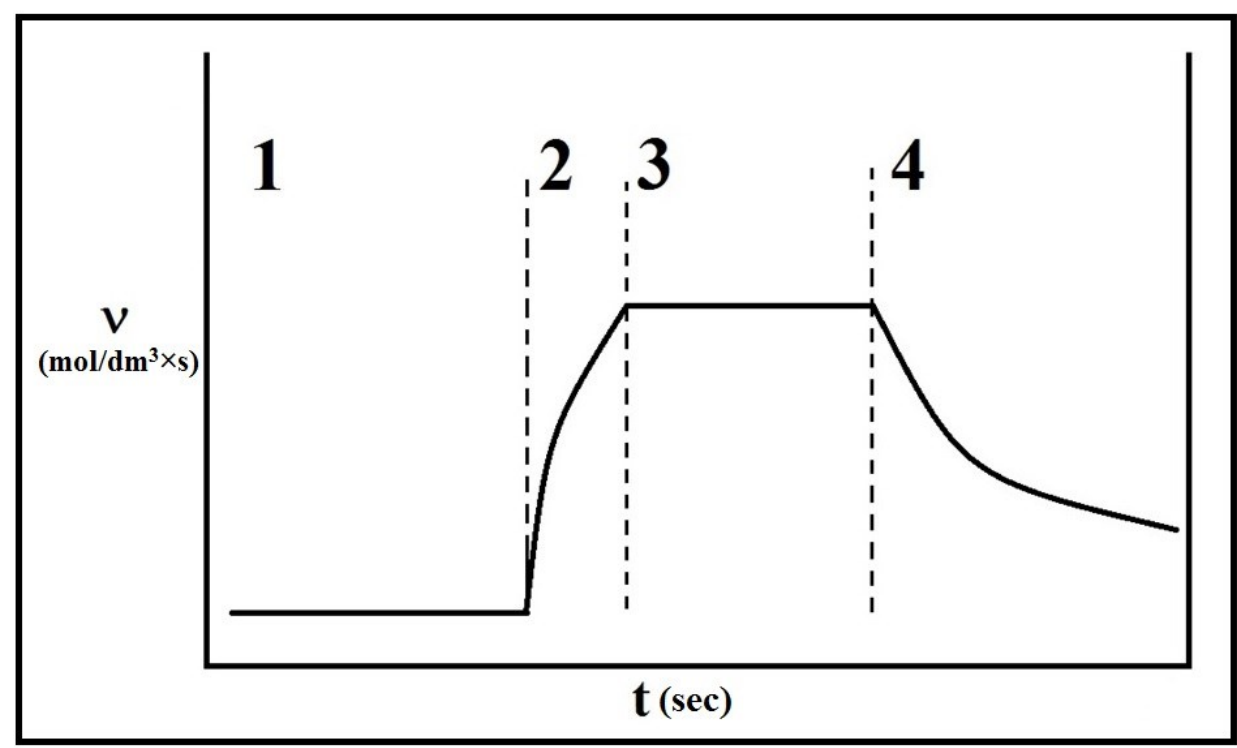

2.3. ábra: mechanikai reakciók általános kinetikája (ahol „,v” a reakciósebesség, „t” az idő). 1 - kiindulási állapot; 2 - gyorsan növekvő reakciósebesség a kezelés hatására; 3 - stabil, kvázi stacioner állapot; 4 - lassuló reakciósebesség. ${ }^{30}$ 
A folyamat tehát négy egymástól jól elkülönülő szakaszra bontható:

1) Az első szakaszban a kezeletlen mintában a reakció sebessége nulla (vagy mérhetetlenül kicsi). A két anyag érintkezik ugyan, de megfelelő aktiválási energia nélkül a reakció nem indul el.

2) A második szakaszban megkezdődik a mechanikai energiaközlés. Mivel a rendszerben ekkor a reaktánsok bőségesen rendelkezésre állnak, egy gyorsan emelkedő függvény jellemzi a reakciósebességet.

3) A kiindulási anyagok fogyásával egy közel egyenletes szakasz következik, amikor a reakciósebesség eléri maximális értékét. A mechanikai behatás ezt a „,végsebességet” tudja leginkább befolyásolni azáltal, hogy defektusokat, reaktív centrumokat hoz létre a szilárd anyag felszínén, valamint a keverés által növeli a kiindulási anyagok érintkezésének gyakoriságát.

4) A negyedik szakaszban a termékképződés fokozatosan lassul, mivel a fogyatkozó kiindulási anyagok egyre kisebb eséllyel találkoznak egymással. A nulla érték felé konvergáló reakciósebesség minimális értéke nem feltétlenül jelenti az összes kiindulási anyag átalakulását. Ez az őrlés közben becsapdázódott (pl.: az őrlőedény falára kitapadt) prekurzorok miatt van, melyek már nem alakulnak termékké (2.8.2.3 fejezet).

Az alap elképzelés, miszerint a mechanikai aktiváció okozta defektusok koncentrációja határozza meg a reakció sebességét, az utóbbi 30 évben nem igazán változott. ${ }^{26,86}$

A reakciósebesség mellett a részecskék méretének változása is több szakaszra bontható. Nem egyértelmü, hogy az örlés során az egyes szilárd részecskék darabolódása kizárólag a kritikus méretig folyik, mivel anyagi tulajdonságuktól függően a csökkenő tendencia meg is fordulhat (A kritikus méret azt a legkisebb átmérőt jelenti, amit az adott örlési körülmények közt elérhetünk. Ennek gyakorlati határát Schönert és kollégái határozták meg szilícium kristályokon, ${ }^{87}$ ahol különleges körülmények közt, nagyon alacsony hőmérsékleten sikerült néhány $100 \mathrm{~nm}$ átlagos átmérőt őrléssel elérniük). A felület változását az őrlés során Avvakumov és társai vizsgálták. ${ }^{88,} 89$ Ők a folyamatot három szakaszra bontották. Amennyiben az anyag nem eleve kritikus méretű, úgy a mechanikai hatásra először egyértelmü darabolódás indul be. Ez polikristályos anyagoknál a szemcsék határain, illetve a mikrorepedések mentén történik. A mechanikai gerjesztés által kialakuló többlet defektusok hatására a darabolódás mértéke és ezzel együtt a felület is növekszik. A második szakaszban az előző folyamat mellett már a plasztikus deformáció is szerephez jut. Az ilyen hatást 
szenvedő részecskék már nem járulnak hozzá a felület további növeléséhez. A harmadik szakaszban a túlzott mechanikai energiaközlés az energia felhalmozódását okozza, ami másodlagos részecskéket eredményez polimorf módosulatok megjelenésével, vagy szintereződés révén. ${ }^{90,}{ }^{91}$ Mivel ekkor már nincsen további darabolódás, a felület csökkenése figyelhető meg. Ha elég kevés energiát fektetünk be az örlés során, úgy a teljes folyamat megáll a plasztikus deformációnál, így a rendszerünk a harmadik szakaszba nem lép át.

Mindemellett megjegyzendő, hogy ez az egyszerüsített modell nem képes magyarázni a nanoméretű részecskék kialakulását malmokban, holott ez ma már jól ismert módszer. A lényeg a teljes őrleményben lévő nanoméretű részecskék arányában van, aminek a termék teljes mennyiségéhez képest a lehető legtöbbnek kell lennie (amennyiben a célméret ez a tartomány volt).

\subsection{Nagy energiájú őrlés}

Míg az alacsony energiájú őrlésen első sorban egy adott anyag felaprítását, addig a nagy energiájú őrlés alatt a mechanikai ötvözést/aktiválást értjük. ${ }^{92}$ A nagy energiájú őrlés célja az erőteljesebb méretcsökkentés és nagyobb mechanikai aktiváció elérése. Maga a „nagy energia” nem pontosan definiált, ugyanakkor szembetünő különbségekben nyilvánul meg. Ez az érték általánosan $\sim 40 \mathrm{~mJ} /$ beütés. $^{93} \mathrm{Az}$ eddig bemutatott mechanikai aktiváció és a mechanokémiai reakciók kinetikája azonban leginkább a nagy energiájú őrlések keretein belül értelmezhetőek igazán. Így nem csak a kritikus méret további csökkentésére vagyunk képesek, hanem kémiai kötések felszakításával új termékeket is létrehozhatunk.

A különböző eszközök nem egyforma hatást fejtenek ki a kezelt anyagra. Az energia több csatornán is átadódhat, ami később darabolódáshoz, illetve mechanikai aktivációhoz vezethet. Mindez természetesen attól függ, hogy az adott malom milyen jellegü kinetikai munkával milyen hatást gyakorol a közegre. Így négy alapvető stressz fajta érheti az őrölt anyagot. Ezek a nyomás, a nyírás, az ütés és a becsapódás (2.4. ábra): 


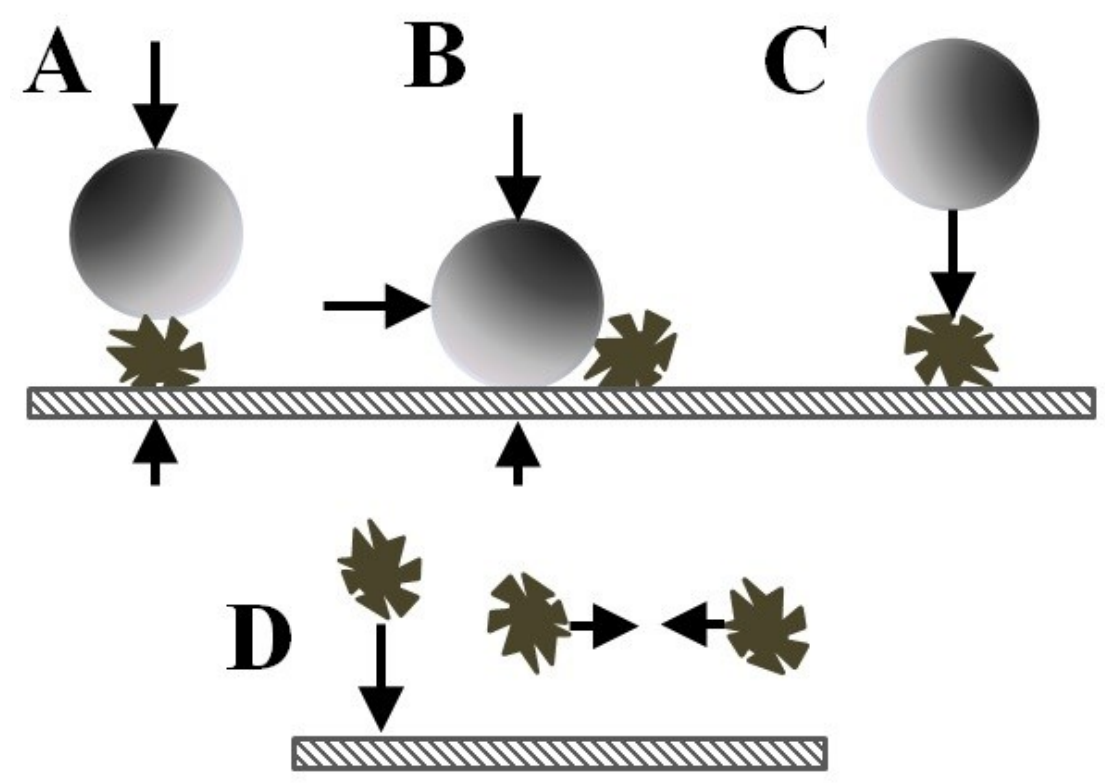

2.4. ábra: a malomtípusok mozgásaiból eredő erőhatások. A - nyomás; $\mathrm{B}$ - nyírás; C - ütés; D - becsapódás, ütközés. ${ }^{30}$

- Nyomás: az őrlemény a golyó és az edény fala (vagy másik golyó) közé szorulva veszi át az energia egy részét. Ez jellemzően akkor történik, ha az őrlőgolyók nem hagyják el az edény falát, hanem azzal együtt mozognak.

- Nyírás: az edény falán vagy egymáson elgördülő (tehát nem folyamatosan azzal együtt mozgó) golyók mozgását az őrlőedény falára merőleges és egy előre mutató erővektor határozza meg, így az anyag mintegy a golyók alá préselődik.

- Ütés: a golyók egy ponton elhagyják az edény falát, majd egy másik pontba becsapódva adják át energiájuk egy részét az anyagnak.

- Becsapódás: maga az őrölt anyag ütközik az edény falába vagy egy másik részecskébe.

A fenti mozgások mindegyike golyósmalmokra jellemző. Léteznek nagy energiájú rudas illetve őrlőközegmentes malmok is (pl.: „pin mill” - tüs malom), melyekben a fentiektől eltérő erőhatások uralkodnak. Ugyanakkor ezek a mozgások nem különülnek el kategorikusan. Egy bolygó golyósmalomban mind a négy jelenség érvényesül, természetesen más-más arányban. Optimális esetben túlnyomóan a „B” és „C” típusok jelentkeznek (2.4. ábra).

\subsubsection{Az őrlés fontosabb eszközei}

A nagy energiájú őrlések irodalmát tanulmányozva különböző felépítésű malmokat találhatunk. A főbb malomtípusok egymástól abban térnek el, hogy milyen mozgás révén 
közlik a mechanikai energiát. A következőkben csak a nagyobb csoportokat tekintjük át, kiemelten foglalkozva a bolygó golyósmalommal, amivel a dolgozatban tárgyalt őrléseket végeztük. Néhány malomtípus mozgási sémáit a 2.5. ábrán mutatom be.

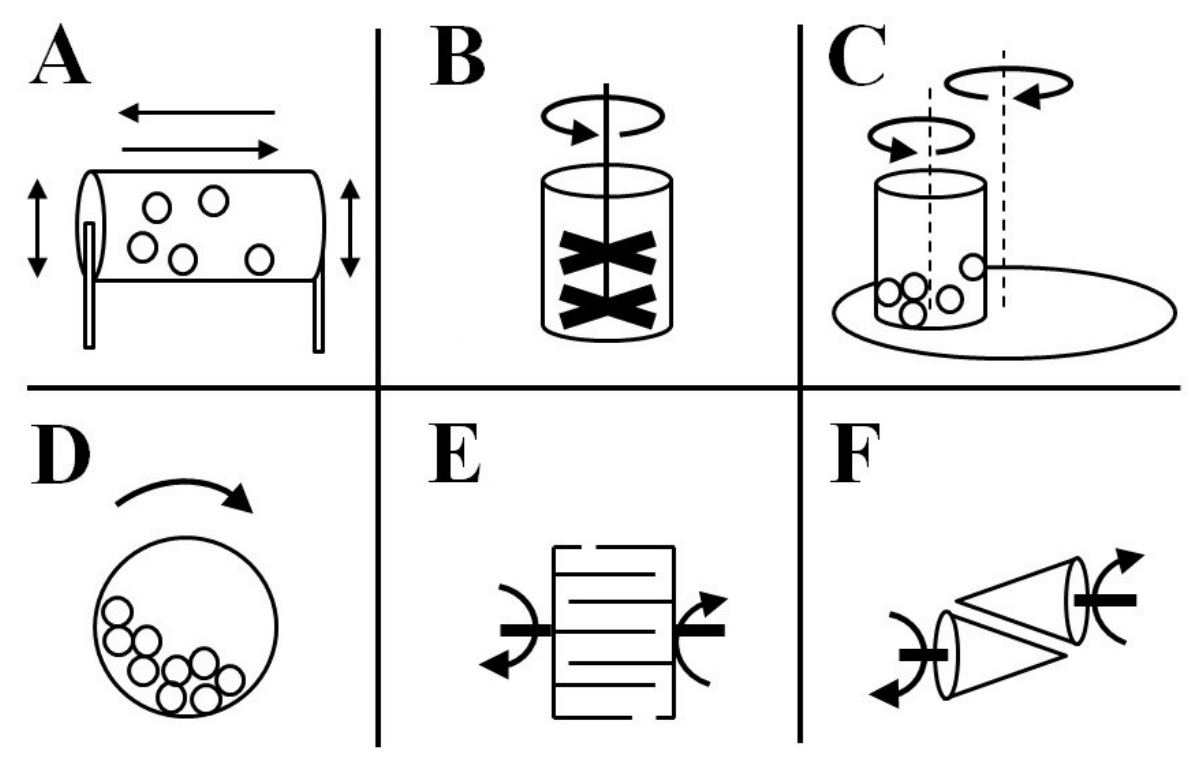

2.5. ábra: a fontosabb malomtípusok mozgási sémái:

$\mathrm{A}$ - vibrációs malom; $\mathrm{B}$ - attritor; $\mathrm{C}$ - bolygó golyósmalom; D - egytengelyes golyós malom; $\mathrm{E}$ - tüs malom; F - görgős malom.

\subsubsection{Vibrációs és keverö malmok}

A vibrációs malomban - néhány kivételtől eltekintve - egy henger alakú őrlőtégelyt találunk, benne a vele együtt mozgó golyókkal és az őrölt közeggel (2.5./A ábra). Feltalálója Mark Lintz. ${ }^{94}$ Később Gock és Kurrer munkássága révén alakultak ki a ma is használatos vibrációs malmok. ${ }^{95,} 96$ Ezeket széles körben alkalmazták a múltban és jelenleg is számos laboratóriumban található ilyen eszköz. A vibrációs malmok a rezgés frekvenciájával, valamint az örlődob kilengésének amplitúdójával jellemezhetőek, melyek általában $15-30 \mathrm{~Hz}$ és 50-60 mm közti értékek. A malom 3 ortogonális irányban végez rezgő mozgást. A dob egy perc alatt akár ezerszer is lenghet elöre-hátra, valamint a tengely két végén oldalirányban. A golyók minden mozdulatnál a mintába csapódnak kb. $5 \mathrm{~m} / \mathrm{s}$ sebességgel, miközben át is keverik azt. Az így közölt energia már elegendő lehet a nagy energiájú őrléshez. Ehhez a motor, melynek mozgása áttételeken keresztül alakul át rezgéssé, akár 1200-1500 rpm fordulatszámmal is foroghat.

A vibrációs malmok néhány típusa két őrlődobot is tartalmaz, mellyel az őrlemény mennyisége növelhető. Az őrlőedények a többi malomnál is ismert anyagból készülnek (pl: 
rozsdamentes acél, achát stb.). Mára megoldódott a vibrációs malmok méretnövelése is, így azok alkalmazása is elterjedt főként az élelmiszer- és építőiparban. ${ }^{97,98,99,100}$

\subsubsection{Attritorok}

A nagy energiájú őrléshez alkalmazott első malomtípus az attritor volt, melyet J.S. Benjamin használt alligációra az 1970-es években. ${ }^{101}$ Az eszköznek magyar vonatkozása is van, hiszen feltalálója Andrew Szegvari, ${ }^{102}$ aki ha amerikai állampolgár is volt, magyar felmenőkkel bírt. Az általa alapított cég (Union Process Inc.) a mai napig családja tulajdonában van. Ezek az eszközök már tekintélyes mennyiségü (akár 50 kg) anyagot képesek átdolgozni, ugyanakkor a bennük keltett mechanikai energia a többi malomhoz képest alacsony.

Az attritorokban az őrlőgolyók és az őrlemény is egy álló tartályban helyezkednek el (2.5./B ábra). Ezt a rendszert egy, az edénybe benyúló, oldalirányban több helyen elágazó keverőkar tartja mozgásban igen nagy fordulatszámon ( 250-300 rpm). A tengely és ezzel együtt a malom elhelyezkedhet vízszintesen és függőlegesen is, a lapátok geometriája pedig lapos, hengeres vagy csavart is lehet. A golyókat a lapátok hozzák mozgásba, melyek egymással, az edény falával, valamint a lapátokkal ütközve adják át az energiát az őrleménynek. ${ }^{103}$ A nagymértékü melegedés miatt ezek a rendszerek hütést igényelnek, ugyanakkor előnyük, hogy a rögzített dob miatt lehetőség nyílik gázok be-, illetve elvezetésére is őrlés közben. ${ }^{104}$

\subsubsection{Bolygó golyósmalmok}

A bolygó golyósmalom ma az egyik legelterjedtebb laboratóriumi malomtípus. Könnyü használata és tartóssága is növeli népszerüségét. Befogadóképessége a néhányszor száz gramm töltőmennyiségig terjed. Egyes típusai egyszerre akár négy örlőedényt is képesek befogadni, ami a különféle minták előállítását nagyban meggyorsítja. A fő különbség az egyes eszközök között a malom befogadóképességében és maximális fordulatszámában van.

Joe Crites volt az első, aki szabadalmat jegyzett be 1933-ban egy általa kifejlesztett bolygó golyósmalomról. ${ }^{105}$ Ma a németek járnak élen a laboratóriumi őrlőeszközök készítésében. Több gyártó közül jelenleg a Fritsch GmbH, a Retsch GmbH vagy a Netzsch GmbH biztosít megfelelő berendezéseket a kutatók számára. A bolygó golyósmalom nevét az őrlőedény mozgásáról kapta, amit úgy kell elképzelni, mint ahogy egy bolygó kering a 
csillaga körül. Az alaplemezen egy edénytartó tégely helyezkedik el excentrikusan a központi tengelytől. Egy áttétel segítségével az őrlőedény az alaplemez forgási irányával ellentétesen kering saját, valamint az alaplemez tengelye körül (2.5./C ábra). Ez eredményezi az őrlőedényben a golyók speciális mozgását, melyek az anyagnak főleg súrlódás (nyírás) és ütések révén adják át energiájukat.

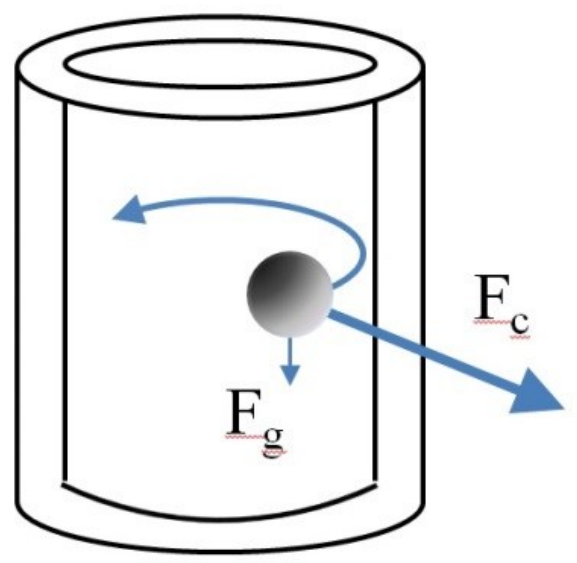

2.6. ábra: egy golyó mozgását meghatározó erők egytengelyü golyós malomban, ahol $\mathrm{F}_{\mathrm{g}} \mathrm{a}$ golyóra ható gravitációs erő, $\mathrm{F}_{\mathrm{c}}$ a golyóra ható centrifugális erö.

Az egyes golyók mozgásának leírásával már többen is próbálkoztak mind fizikai megfontolások ${ }^{106-108}$, mind közvetlen megfigyelések ${ }^{109,110}$ alapján. Nehézséget jelent azonban az eltérő geometriájú malmokban tapasztalható mozgások sokfélesége. Máig nem sikerült egy mindenki által elfogadható, a golyók mozgását és az ebből számítható energiát általánosan leíró modellt felállítani.

Egy egytengelyü malomban az egyes őrlőgolyók helyzetét a forgómozgás miatt egy kifelé mutató erő és a gravitációs erő határozzák meg. A golyókra ható pillanatnyi eredő erővektor a centrifugális erő miatt általában az őrlőedény falára közel merőlegesen kifelé mutat. Végeredményben a golyók így kényszerülnek az edény falán, egy körkörös pályán mozogni (2.6. ábra). A bolygó golyósmalmokban a második tengely beiktatása miatt a golyók mozgása lényegesen bonyolultabbá válik.

Az egytengelyü fekvő malmokban a forgás sebességétől függően három mozgástípust figyelhetünk meg (2.7. ábra). ${ }^{109}$ 

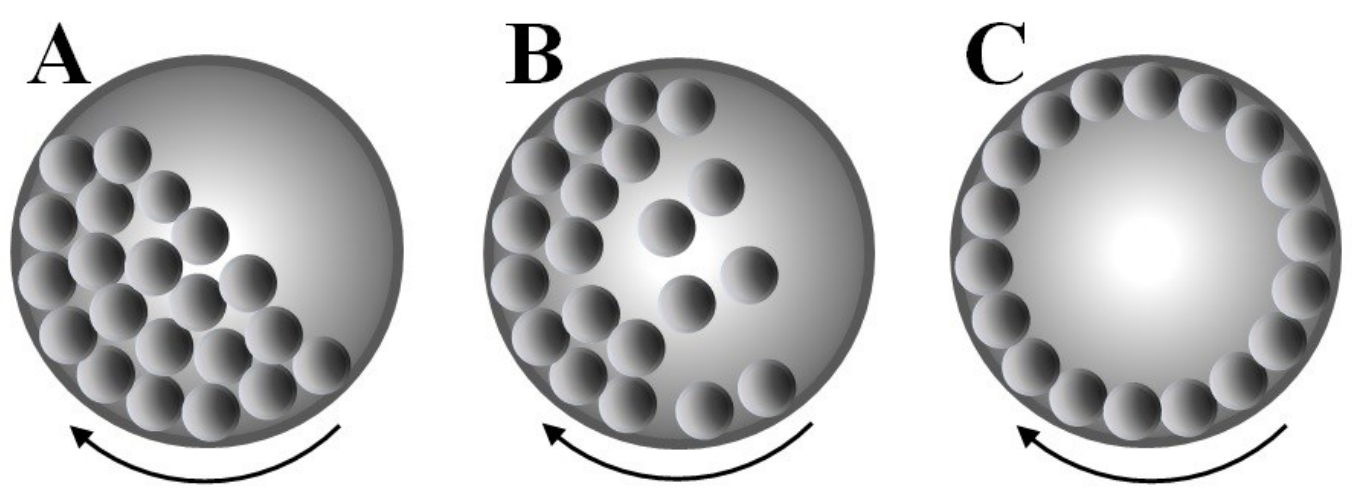

2.7. ábra: egytengelyű malom őrlőedényében különböző fordulatszám mellett kialakuló golyómozgások. A: kaotikus; B: vízesés; C: súrlódásos.

Egy kritikus sebesség alatt a golyók egymáson elgördülve mozognak, kevés energiát közölve a rendszerrel (2.7./A ábra). A kritikus sebesség felett a centrifugális erő hatására az edény falához préselődnek (2.7./C ábra), azon elgördülnek, s ekkor a súrlódás miatt viszonylag nagy energiát adnak át a közegnek. Még nagyobb fordulatszám mellett a golyók már az edény falával együtt mozognak. Ennek az a hátránya, hogy ugyan egy pontban állandó nyomást fejtenek ki az őrleményre, de mivel ahhoz képest nem mozdulnak el, az energiaközlés nem terjed ki az örölt közeg teljes térfogatára. A két érték határán, egy szük sebességtartományban a golyók az edény legfelső pontjáig mozognak, majd onnan leesnek és a szemközti oldalon becsapódnak (2.7./B ábra). Ebben a fordulatszám tartományban a golyók nem tesznek szert akkora mozgási energiára, ami nagy energiájú őrléshez elegendő lenne.

Ugyanezek a mozgások a függőleges tengelyü malmokban is hasonlóan lépnek fel azzal a különbséggel, hogy az „A” esetben a golyókra - kölcsönhatásaik miatt - az edény belseje felé mutató eredő erő hat, ezért ekkor csekély az őrlési hatékonyság. A „B” esetben a centrifugális erő már jelentősen meghaladja a befelé ható erőket, így súrlódás, valamint a golyók átrepülése (az őrlőedény belsejében) miatt ütések is fellépnek. A „C” eset megegyezik a fent leírtakkal.

Bolygó golyósmalomban lényegében a „B” mozgást kívánjuk elérni úgy, hogy a golyók kinetikus energiájuk nagy részét (ami jelen esetben nem a gravitációs gyorsulásból ered) a közegnek adják át. Ezt a következőképpen képzelhetjük el (2.8. ábra): a gyorsan forgó őrlődob miatt az őrlőgolyók nagy mozgási energiára tesznek szert. A forgásból eredő centrifugális erő a korábban bemutatott esetek (2.7. ábra) közül a „C” típusú pályára kényszeríti az őrlőgolyókat, amik így az őrlőedény falán gördülve körkörös pályán haladnak. A központi lemez tengelye körüli ellentétes irányú forgó mozgás viszont kimozdítja az 
őrlőedényt a golyók körpályán bejárt útjából, így a felhalmozott kinetikai energiával rendelkező golyók - mint egy lövedék - az edény B pontjába csapódnak.

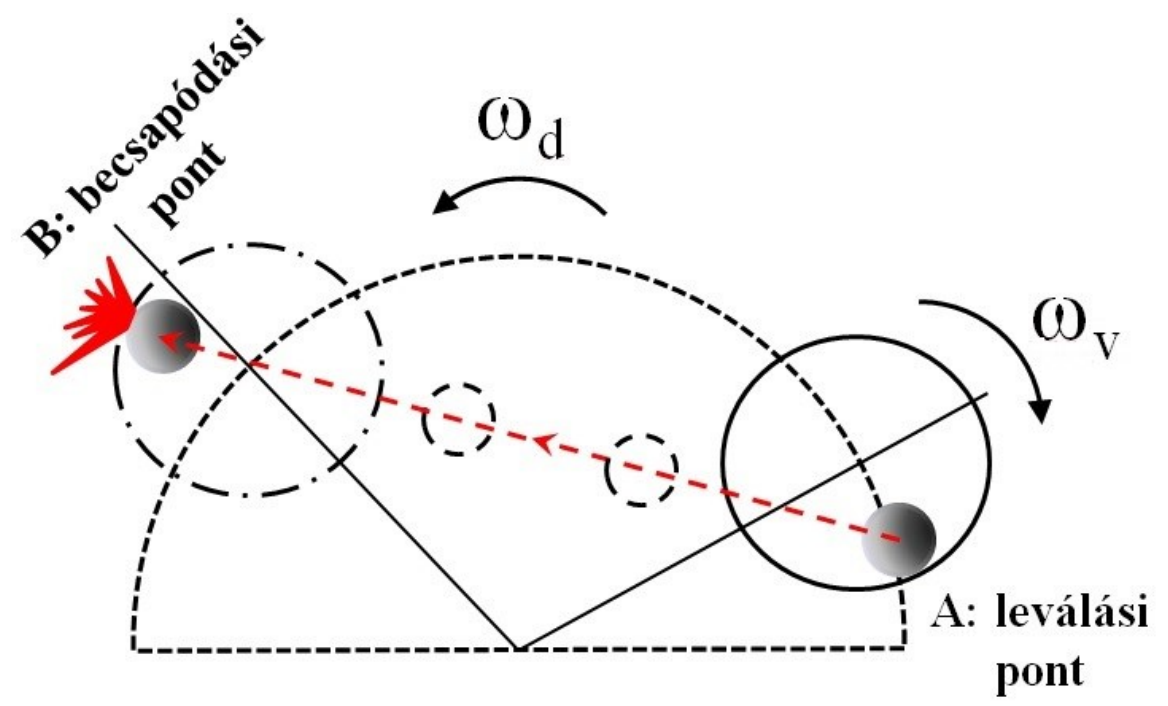

2.8. ábra: egy golyó mozgási pályája bolygó golyósmalomban. Az „A” pontban az edény faláról leváló golyó a „B” pontba csapódik. $\omega_{\mathrm{d}}$ az alaplemez, $\omega_{\mathrm{v}}$ az őrlőedény forgási sebessége.

Az így létrejövő golyómozgás folyamatosan bombázza az őrleményt. Mivel az őrlőedény forgása elég gyors, az őrlemény nagyon gyorsan keveredik, tehát az egy-egy részecskére ható behatások sürün követik egymást. Ez teszi lehetővé, hogy a közölt energia akkumulálódjon és olyan folyamatokat is beindítson, melyekhez egyetlen becsapódás energiája nem lenne elég.

\subsubsection{Az őrlési energiát befolyásoló tényezők}

Az egyes malomtípusok felépítésükböl adódóan számos paraméterrel bírnak. A továbbiakban kifejezetten a bolygó golyósmalmokra jellemző tulajdonságokat mutatom be.

$\mathrm{Az}$ őrlési paraméterek végső kinetikai energiára kifejtett szerepével számos kutatócsoport foglalkozik. ${ }^{111-113}$ Ezeket két nagy csoportba sorolhatjuk. Az egyikbe tartoznak az őrlés energiáját befolyásoló állandók. Ilyen például az alaplemez sugara $\left(r_{m}\right)$ és bizonyos malmoknál az alaplemez és az őrlőtégely áttétele $\left(i_{r e l}\right)$, azaz fordulatszámaik aránya. A másik paramétercsoportba az őrlés müveleti változói tartoznak (pl. őrlés ideje, golyók száma). A 2.9. ábrán a malom egyes részeire vonatkozó paramétereket foglalom össze, a 2.8.2.1 2.8.2.4 fejezetekben pedig valamennyi változót részletesen tárgyalom. 


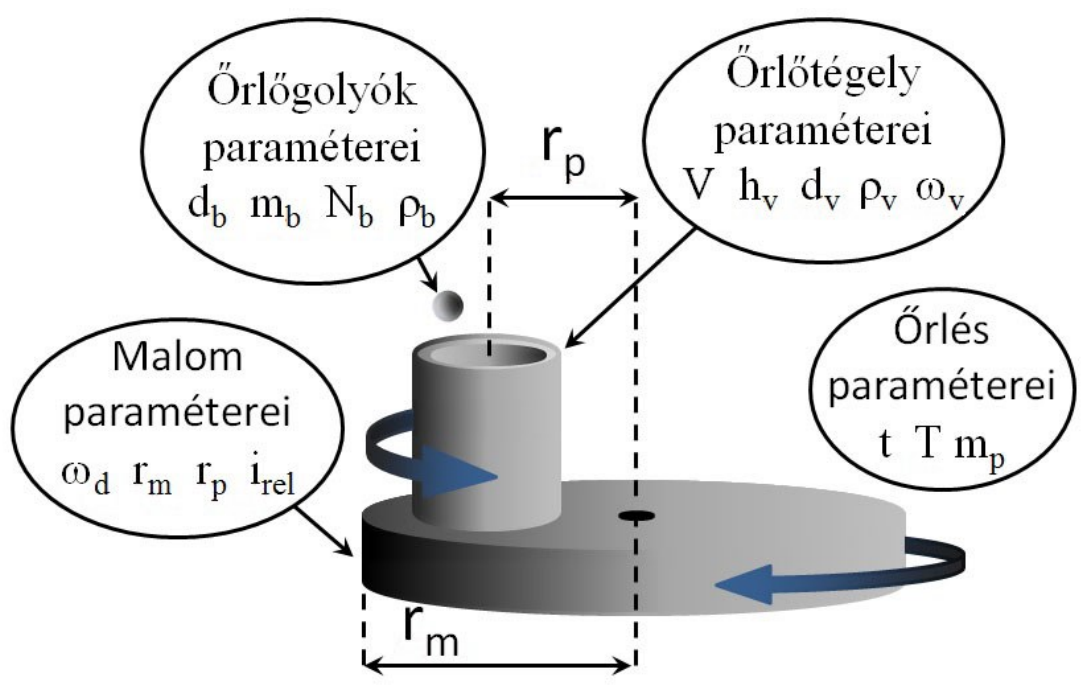

2.9. ábra: az őrlést befolyásoló paraméterek bolygó golyósmalom esetén.

\subsubsection{A malom paraméterei}

Általában a malom paraméterei a nem változtatható értékek közé tartoznak és az alkalmazott malom típusától függnek. Az első tényező tehát maga a malom, ami a korábban bemutatott eszközök közül jelen esetben kizárólag a bolygó golyósmalom altípusait jelenti. Csak a Fritsch GmbH kínálatában 6 különböző ilyen készüléket találhatunk. Különbség köztük a befogható őrlőedények maximális méretében és számában, a forgási sebességben $\left(\omega_{d}\right)$ és az áttételben van. Az edények száma 1-6 db, a térfogatuk pedig 20-1000 $\mathrm{cm}^{3}$ között változhat. A malmok maximális fordulatszáma a méretükkel fordítottan arányosan változik, így a legnagyobbak 100-400 rpm, a közepesek 100-650 rpm, míg az asztali malmok akár 1100 rpm értékre is beállíthatóak. Ugyanakkor a kisebb malmok kisebb tömegü golyók befogadására képesek, ami csökkenti az átadható maximális energiát.

Az áttétel, azaz az alaplemez és az őrlőtégely forgási sebességének aránya a két tengely távolságának változtatásával $\left(r_{p}\right)$ szabályozható. Bizonyos malmokban ez állandó érték, míg az állíthatóakban -1 és -2,2 között adható meg. A negatív előjelet az ellentétes forgási irány indokolja. A malmokon mindig az alaplemez fordulatszámát adhatjuk meg, amiből az őrlőedény fordulatszáma az áttétel alapján számolható. -2,2 érték alatt tanulmányok szerint az őrlés hatékonysága radikálisan csökken, mivel ekkor megbomlik az őrlőgolyók bolygó golyósmalmokra jellemző mozgása, így nem történik meg azok leválása az edény faláról. ${ }^{107}$ A malom paraméterei közül a befogadóképesség az őrlemény mennyiségét, míg a fordulatszám és az áttétel a golyók energiáját határozzák meg. 


\subsubsection{Az örlöedény paraméterei}

A ma laboreszközként kapható őrlődobok és őrlőgolyók összetételét és néhány tulajdonságát a 2.1. táblázatban mutatom be.

\begin{tabular}{c|c|c|c|c|c}
$\begin{array}{c}\text { Őrlőedény/golyó } \\
\text { anyaga }\end{array}$ & Jelölés & $\begin{array}{c}\text { Sürüség } \\
\left(\mathbf{g} / \mathbf{c m}^{3} \mathbf{)}\right.\end{array}$ & $\begin{array}{c}\text { Mohs- } \\
\text { keménység }\end{array}$ & Kopásállóság & Fő alkalmazás \\
\hline Achát & $\mathrm{SiO}_{2}$ & 2,65 & 6,8 & jó & képlékeny minták \\
\hline Szinterelt korund & $\mathrm{Al}_{2} \mathrm{O}_{3}$ & 3,8 & 9 & nagyon jó & kemény minták \\
\hline Szilícium-nitrid & $\mathrm{Si}_{3} N_{4}$ & 3,25 & 5 & kiváló & fémmentes őrlés \\
\hline Cirkónium-oxid & $\mathrm{ZrO}_{2}$ & 5,7 & 8,7 & nagyon jó & koptató minták \\
\hline Rozsdamentes acél & $\mathrm{Fe}-\mathrm{Ni}-\mathrm{Cr}$ & 7,8 & 7,9 & nagyon jó & rideg minták \\
\hline Edzett acél & $\mathrm{Fe}-\mathrm{Cr}$ & 7,9 & 8 & jó & rideg minták \\
\hline Volfrám-karbid & $\mathrm{WC}$ & 14,95 & 9,2 & nagyon jó & koptató minták \\
\hline
\end{tabular}

2.1. táblázat: a leggyakrabban alkalmazott őrlőedények és őrlőgolyók összetétele, valamint főbb tulajdonságaik (az általunk használt örlődobok ferdén szedve).

Azt, hogy milyen anyagból készült edényt választunk, az őrlemény anyaga és a munka célja határozzák meg. A 2.1. táblázatból láthatjuk, hogy a főbb alkalmazási területek szerint léteznek puha, közepesen kemény, rideg és kifejezetten koptató őrlemények aprítására szolgáló őrlődobok. A megfelelő döntéshez ismernünk kell az őrlemény Mohs-skálán elfoglalt helyét, vagy az azzal egyenértékü keménységi fokát. ${ }^{114}$ Az átváltást az amerikai ASTM-E140 illetve az ISO 18265 számú szabványok határozzák meg. Amennyiben az őrölni kívánt anyagunk a golyóknál és az őrlődobnál keményebb, úgy előfordulhat, hogy az őrlődob és a golyók erősen kopni fognak és ezzel szennyezik a mintánkat. Ez a szennyezés még az őrlőedény helyes megválasztása esetén is csak nehezen elkerülhető. Főként az ötvözetekből készült őrlőedényekkel végzett aprítás végén tudjuk kimutatni a mintánkban a dob összetételére jellemző elemeket (pl.: Fe, Cr). Fémszennyezés-mentes őrléshez rendelkezésünkre állnak nagy kopásállóságú kerámia edények is, ilyen például az általunk is használt $\mathrm{Si}_{3} \mathrm{~N}_{4}$.

Egy őrlőedény anyagán kívül a következő paraméterekkel bír még: az edény magassága $\left(h_{v}\right)$, belső átmérője $\left(d_{v}\right)$, térfogata $(V)$, sürüsége $\left(\rho_{v}\right)$ és fordulatszáma $\left(\omega_{v}\right)$. A fordulatszám a 2.8.2.1 fejezetben leírtak szerint az alapbeállítás mellett az áttételtől is függ. Az őrlőedény dimenziói közül a térfogat az egyszerre megőrölhető anyag maximális mennyiségét, míg a belső átmérő a golyók mozgását határozza meg. Amennyiben a belső átmérő túl kicsi a 
golyókhoz képest, úgy a szabad mozgást a golyók túlzott mennyisége akadályozhatja. Az őrlés közben átadott energiát alapvetően az őrlödob és golyók sürüsége, valamint a fordulatszám határozzák meg.

\subsubsection{Az örlögolyó paraméterei}

$\mathrm{Az}$ örlőgolyók és az őrlőedények anyagi minőségükben (összetétel, sűrüség, keménység) megegyeznek egymással. Alapvető fontosságú, hogy őrléskor kizárólag ugyanolyan összetételü rendszert használjunk. Amennyiben ez nem valósul meg, úgy a golyó vagy az edény erősebb koptató hatást fejtene ki a másikra, így a minta szennyezése is jelentősebb lenne.

Az őrlőgolyók sajátos paraméterei az átmérő $\left(d_{b}\right)$, a tömeg $\left(m_{b}\right)$, a golyók száma $\left(N_{b}\right)$ és sürüsége $\left(\rho_{b}\right)$. Ez utóbbira nem igaz a „minél több annál jobb” elv, helyette két szabályt kell szem előtt tartanunk: (1) Meg kell tartani az őrlőedény térfogatának és a golyók össztérfogatának helyes arányát. Könnyen beláthatjuk, hogy egyetlen golyó önmagában kevés a nagy energiájú őrlések kivitelezéséhez, míg az őrlőtégely térfogatának teljes kitöltése a golyók mozdulatlanságát okozná. A helyes arány nagyban függ a malomtípustól. ${ }^{115}$ Bolygó golyósmalmoknál ez az arány 20-30 \%-os kitöltöttség között optimális. ${ }^{116}$ (2) Emellett be kell tartani a helyes golyó-őrlemény tömegarányt is. Ez több aspektusból is lényeges. Egyrészt feleslegesen sok golyó többletszennyezést juttathat a mintába, valamint növeli a veszteséget a túlzott kitapadás miatt, másrészt túl kevés golyó viszont nemcsak gyenge őrlési hatásfokot eredményezhet, hanem egy kritikus érték alatt már nem lesz képes az őrleményt megfelelően átkeverni. Az arány 1:10 és 1:5 között optimális a golyók össztömegének javára. ${ }^{117} \mathrm{Ez}$ a paraméter alapvető fontosságú a termék minőségének szempontjából. ${ }^{118-121}$

Az őrlőgolyók és az őrlőedény helyes megválasztása esetén is számolnunk kell - a minta szennyezése mellett - őrlési veszteséggel. Ez a megőrölt anyagnak az a része, ami az őrlés hatására az edény falára és a golyók felületére tapad. A kitapadás jelenségét több dolog is előidézheti. Okozhatja az örlemény nedvessége (pl.: kristályvíz tartalom miatt), az örlőedény egyenetlen fala vagy az örlemény alacsony hőtürése, ami miatt bevonat keletkezhet a golyókon. Negatív hatása egyértelmü: csökkenti az őrlés hatékonyságát. A kitapadt anyag becsapdázódik, így egyrészt nem kap elegendő energiát, másrészt nem keveredik el az őrlemény többi részével, ami végül veszteséget és minta-inhomogenitást okoz. A jelenség hatásának csökkentésére a fent említett arányok betartása mellett egyéb eszközök is rendelkezésünkre állnak (lásd: 4.2.1 fejezet). 


\subsubsection{Az őrlés paraméterei}

Természetesen az örlési körülmények is befolyásolják a termékképződést. A bemért anyag tömege $\left(m_{p}\right)$ a már említett arányok miatt fontos, de lényeges még az őrlés ideje $(t)$ és az őrlőedényen belüli hőmérséklet $(T)$ is. A rendszernek elég időt kell adni ahhoz, hogy a mechanikai aktiváció megindulhasson.

Attól függően, hogy milyen őrlőedények, illetve malom áll rendelkezésünkre, megválaszthatjuk akár a zárt rendszer gázterének összetételét is. ${ }^{122}$ Szükség lehet például inert, ${ }^{123}$ vagy reduktív körülményekre, ${ }^{124,125}$ így hozva létre a megfelelő terméket. Lehetőség van a tégely temperálására, illetve magas nyomáson ${ }^{126}$ vagy vákuumban ${ }^{127}$ végzett kísérletekre is. Maguk a lejátszódó reakciók is befolyásolhatják az őrlési körülményeket, például endoterm vagy exoterm reakciók által a hőmérsékletet, vagy gáz melléktermék képződése révén a nyomást. Fontos, hogy mindig vegyük figyelembe ezeket a lehetőségeket a kísérletek megtervezésénél.

\subsection{Az őrlési energia meghatározása}

\subsubsection{A becsapódási $\left(\mathrm{E}_{\mathrm{b}}\right)$ és kumulatív $\left(E_{\text {cum }}\right)$ energia}

Ahhoz, hogy az őrlés közben előállított termékünk képződési körülményeit pontosabban meghatározhassuk, meg kell tudnunk becsülni az őrlőgolyók által az őrleménnyel közölt energiát. A mi tárgyalásmódunk alapja Burgio és társainak munkája, akik közvetlenül vizsgálták a közölt energia és a mechanokémiailag előállított Fe-Zr rendszer tulajdonságai közti kapcsolatot. ${ }^{128}$ Bevezették a becsapódási energia (ball-impact energy - $E_{b}$ ) és kumulatív energia (cumulative energy $-E_{\text {cum }}$ ) fogalmát. Becsapódási energia alatt az egy golyó egy becsapódása által az anyagnak átadott teljes energiáját értjük, amennyiben a következőket feltételezzük: 1) a becsapódás rugalmatlan 2) az ütközés során nem történik mozgás a golyó és a tégely fala közt (megcsúszás) 3) eltekintünk az örlemény közegellenállásától 4) eltekintünk a golyókra ható gravitációs erőtől 5) a golyó nem végez forgó mozgást. A kumulatív energia a teljes őrlés során a rendszernek átadott összes energiát jelenti, melyet a becsapódások frekvenciája $(f)$ a becsapódási energia és az őrlés ideje határoznak meg a bemért örlemény tömegének 1 grammjára normálva.

A modell egyes paramétereinek fontosságát Burgio és társai, Padella, Magini és Iassona írták le. ${ }^{129,130}$ A golyók mozgásának matematikai leírására is több próbálkozás történt, melyek 
közül Chattopadhyay és társai a Burgio féle modellre támaszkodva közölték eredményeiket. ${ }^{107}$ Ezek alkalmazása később elterjedt a mechanokémiával foglalkozó, bolygó golyósmalommal dolgozó kutatók körében. Így már lehetőség van arra, hogy eredményeiket összevessék a világ különböző pontjain más eszközzel végzett kísérletek eredményeivel az őrlés paramétereinek ismeretében. ${ }^{93,131,132}$ A becsapódási energia és kumulatív energia az alábbi egyenletekkel (8-10) számolható:

$$
\begin{gathered}
E_{b}=\frac{1}{2} \Phi\left(\rho_{b} \frac{\pi d_{b}^{3}}{6}\right) \omega_{p}^{2}\left[\left(\frac{\omega_{v}}{\omega_{d}}\right)^{2}\left(\frac{d_{v}-d_{b}}{2}\right)^{2}\left(1-2 \frac{\omega_{v}}{\omega_{d}}\right)-2 r_{p}\left(\frac{\omega_{v}}{\omega_{d}}\right)\left(\frac{d_{v}-d_{b}}{2}\right)-\left(\frac{\omega_{v}}{\omega_{d}}\right)^{2}\left(\frac{d_{v}-d_{b}}{2}\right)^{2}\right] \\
f=N_{b} K\left(\omega_{d}-\omega_{v}\right) \\
E_{\text {cum }}=\frac{E_{b} \times f \times t}{m_{p}}
\end{gathered}
$$

A (9) egyenlettel a golyók becsapódásának frekvenciája határozható meg. Az egyenletben szereplő egyes változókat a 2.8.2 fejezetben mutattam be, valamint a 2.9. ábra részletezi. A (8) egyenletben szereplő „ $\Phi$ ” valamint a (9) egyenletben szereplő „K” az őrlőedény geometriájától, az őrlőgolyók átmérőjétől és az áttételtől függő állandók.

A kumulatív energia a teljes örlés során a golyók által átadott energia, így az nem egyezik meg a mechanikai aktivációhoz szükséges energiamennyiséggel. Ez azzal magyarázható, hogy a mechanikai aktivációt gyakran nem egyetlen ütközés, hanem azok sorozata váltja ki. Az összes golyó által keltett energia nem az őrlemény egyetlen részének adódik át, ráadásul az energia felhalmozódása időben erősen korlátozott. Így az $E_{c u m}$ sokkal inkább a golyók által kifejtett összes energiát jelöli.

\subsubsection{Az örlési térkép}

Örlési térképen jeleníthetjük meg az általunk kalkulált energia függvényében a termék valamely tulajdonságát. Ez lehet részecskeméret-eloszlás, kristályszerkezet-változás vagy valamilyen felületi tulajdonság. Ezek a térképek gyakran három skálával rendelkeznek. A számolt energia mellett érdemes feltüntetni azt a paramétert is, melynek változtatásával eltérő energiát alkalmaztunk. Emellett kap helyet a terméken mért tulajdonságot szemléltető tengely. Így egy olyan diagramot kapunk, melyről könnyedén leolvashatjuk például, hogy a vizsgált anyag egy tulajdonsága milyen fordulatszámon, mekkora becsapódási energia mellett változott meg. 


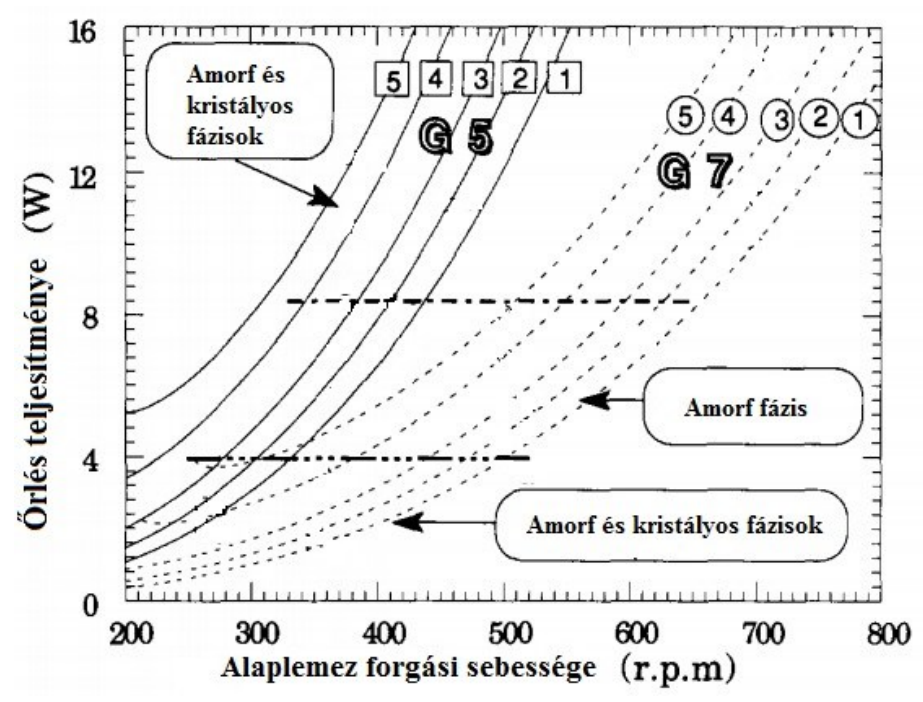

2.10. ábra: példa őrlési térkép, melyen két különböző bolygó golyósmalomban (folytonos és szaggatott vonalak), különböző fordulatszámok mellett vizsgált $\mathrm{Ni}_{10} \mathrm{Zr}_{7}$ ötvözet kristályos fázisait ábrázolták. ${ }^{133}$

Az őrlési térkép fogalmát és ábrázolását Abdeoulli és Gaffet vezették be 1994-ben, amikor $\mathrm{Ni}_{10} \mathrm{Zr}_{7}$ rendszereket, pontosabban azok kristályos fázisait vizsgálták röntgen diffraktometriával. ${ }^{133}$ Többek közt Burgio és társai munkája alapján meghatározták több malomtípusban is a becsapódási energiát, az őrlés teljesítményét és egy golyó sebességét a becsapódás pillanatában. Ezt elsősorban attritorokra, bolygó golyós és vibrációs malmokra, összesen 6 különböző típusra végezték el. A 2.10. ábrán tekinthetjük meg a munkájuk során készült őrlési térképet.

\subsection{A mechanokémia alkalmazása mindennapjainkban}

A mechanokémia első alkalmazási területei olyan nagyobb iparágak voltak, mint a hidrometallurgia, ${ }^{134,}{ }^{135}$ az építőipar vagy a mütrágyagyártás. ${ }^{136-138}$ Ígéretes laboratóriumi kísérletek eredményei ellenére azonban kihívást jelentett a megfelelő teljesítményü nagy energiájú eszközök kivitelezése. Az iparban alkalmazott malmok nem voltak képesek elegendő energiát biztosítani a mechanikai aktivációhoz. A nehéz megvalósíthatóság ellenére több kísérletet is tettek a mechanokémia ipari méretủ alkalmazására. Így sikeres volt például a kén és réz előállítása kalkopiritből nedves kohászattal (Németország), a savmentes mütrágyagyártás foszfátokból (Mongólia) vagy zeolit struktúrájú polimorf szilikalitok szintézise (Spanyolország). ${ }^{139}$ A kisebb méretü ipari ágazatok még biztatóbb eredményeket értek el, így például a színesfém kohászatban a volfrám és aranytartalmú kőzetek feltárásában. 


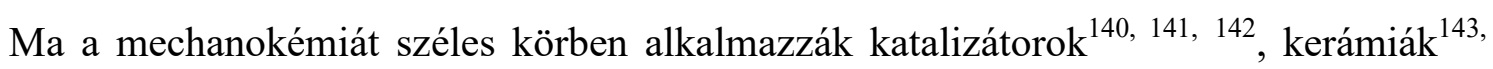
144, 145 és speciális célú anyagok elöállítására ${ }^{146}$, valamint az energiaiparban ${ }^{147,}{ }^{148}$. A gyógyszeriparban is bevett technológia mind a hatóanyag előállítás, őrlés, keverés, vagy a tablettázás területén. ${ }^{149,150}$ Malmokat használ még a festék- és a kozmetikaipar is, ${ }^{151,152}$ a hulladékipar pedig a bróm- és klórtartalmú aromás vegyületek és más halogénezett szénhidrogén tartalmú hulladékok ártalmatlanításánál vetette be őket sikeresen. A hagyományos oxidatív technológiák, mint például az égetőkben történő ártalmatlanítás, erösen környezetszennyező hatásúak, míg az alternatív remediációs eljárások nem mindig elég hatékonyak. ${ }^{153}$ Például a hulladék PVC 56,7 V/v\% klórt tartalmaz, ami égetése során problémát jelent. A 2000-es években bíztató eredményeket értek el a mechanokémiai PVC-deklorináció terén. ${ }^{154} \mathrm{~A}$ hulladékot megfelelő mennyiségü $\mathrm{CaCO}_{3}$-tal és $\mathrm{Ca}(\mathrm{OH})_{2}$-dal összeörölve hozzávetőleg 95\%-os hatékonysággal távolítható el a PVC klórtartalma. A keletkező keverékböl a $\mathrm{CaCl}_{2}$ kioldható és felhasználható. ${ }^{155}$

Tény ugyanakkor, hogy a sikeresen alkalmazott ipari mechanokémiai folyamatok aránya mégis alacsony. Az őrlőeszközök ipari alkalmazhatóságát a mechanokémiai folyamatok jobb megismerésével bővíthetnénk. Véleményem szerint különösen ígéretesek az őrlési energia minimalizálására, a költséghatékony nanorészecske-szintézisre és az oldószermentes vegyipar fejlesztésére irányuló kutatások.

\subsection{Nanotechnológiai alapok}

\subsubsection{A nanoszerkezetủ anyagok}

A nanotechnológia fogalmát K. Eric Drexler vezette be a köztudatba 1986-ban megjelent könyvében (a szót először Norio Taniguchi használta 1974-ben egy konferencián). Ő a nanotechnológiát úgy definiálta, mint az atomok és molekulák precíz manipulálása által létrehozott, sejtnél kisebb szerkezeteket felépítő folyamatok összessége. ${ }^{156} \mathrm{Az}$ újabb meghatározás szerint (National Nanotechnology Initiative) a nanotechnológia tárgykörébe azok az anyagok tartoznak, melyek legalább egyik dimenziójukban nem több mint 100 nanométer kiterjedésűek. Elöállításuk két alapvető módszere a „top-down” (felülröl lefelé, azaz tömbi fázisból valamilyen folyamat által kialakított nanoméretü szerkezetek) és a „,bottom-up” (alulról felfelé, azaz atomi szintről legfeljebb nanométeres tartományig növesztett szerkezetek) megközelítés. Az esetek többségében az utóbbit alkalmazzák. ${ }^{157} \mathrm{~A}$ nanorészecskék mind fizikai, mind kémiai tulajdonságaikban jelentősen eltérhetnek a tömbi fázisú megjelenési formájuktól. Ebben a mérettartományban a felület és térfogat aránya 
megnő, ami a részecskék szabadenergiájának megnövekedésével jár. Például amíg egy 5 nm-es szemcseméretü nanokristályt felépítő atomok mintegy $25 \%$-a már a határfelületen van, addig 100 nm átmérő esetén ez az arány legfeljebb 1-2 \%.

Attól függően, hogy az adott szerkezeti egység hány dimenziójában nem kisebb 100 nm-nél, három csoportot különböztetünk meg (2.11. ábra):

- 0D nanoszerkezetek: izotróp nanorészecskék, nanodot-ok (nanopötty),

- 1D nanoszerkezetek: szálas, csöves szerkezetek,

- 2D nanoszerkezetek: réteges vagy lamellás szerkezet.

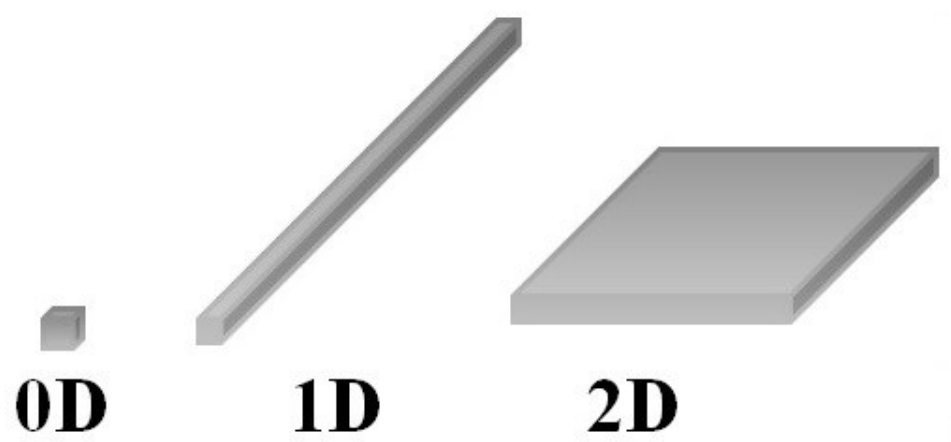

2.11. ábra: a nanokristályos anyagok alakja lehet: $0 \mathrm{D}$, nanorészecske; $1 \mathrm{D}$, szálas, ill. csöves szerkezetü; 2D, réteges ill. lamellás szerkezetü.

A nanoszerkezetủ anyagok kristályos, kvázikristályos, illetve amorf fázisokból épülhetnek fel, melyek lehetnek fémek, félvezetők, kerámiák vagy kompozit anyagok is. A következő három alfejezetben a disszertációmban tárgyalt anyagfajtákat mutatom be.

\subsubsection{Szén nanocsövek}

A többfalú szén nanocsövek (MWCNT) vizsgálata Sumio Iijima 1991-es felfedezésével indult, amikor is fullerének szintézisekor az előállított anyag melléktermékét vizsgálta és csöves szerkezetü anyagról készített elektronmikroszkópos felvételt. ${ }^{158}$ Azóta több mint 140000 szén nanocsövekkel foglalkozó publikáció jelent meg (Web of Science ${ }^{T M}$ : keresés „carbon nanotube” kulcsszóra) és a nanocsövekre több gyakorlati alkalmazást is találtak. A cső szerkezetét hatszöges kötésszerkezetü, $\mathrm{sp}^{2}$ hibridizációjú szénatomokból álló graféncsíkok feltekeredése adja, melynek két végét egy-egy félfullerén zárja le. Az egyfalú szén nanocsövek egyetlen ilyen hengerpalástból állnak, átmérőjük 0,4-3 nm. Többfalú szerkezet esetén ezek a hengerpalástok koaxiálisan egymásba ágyazott formában jelennek meg, átlagos 
átmérőjük (a rétegek számától függően) 2-40 nm. Hosszuk mindkét esetben a néhánytól a több tíz mikrométeres tartományba esik (2.12. ábra).

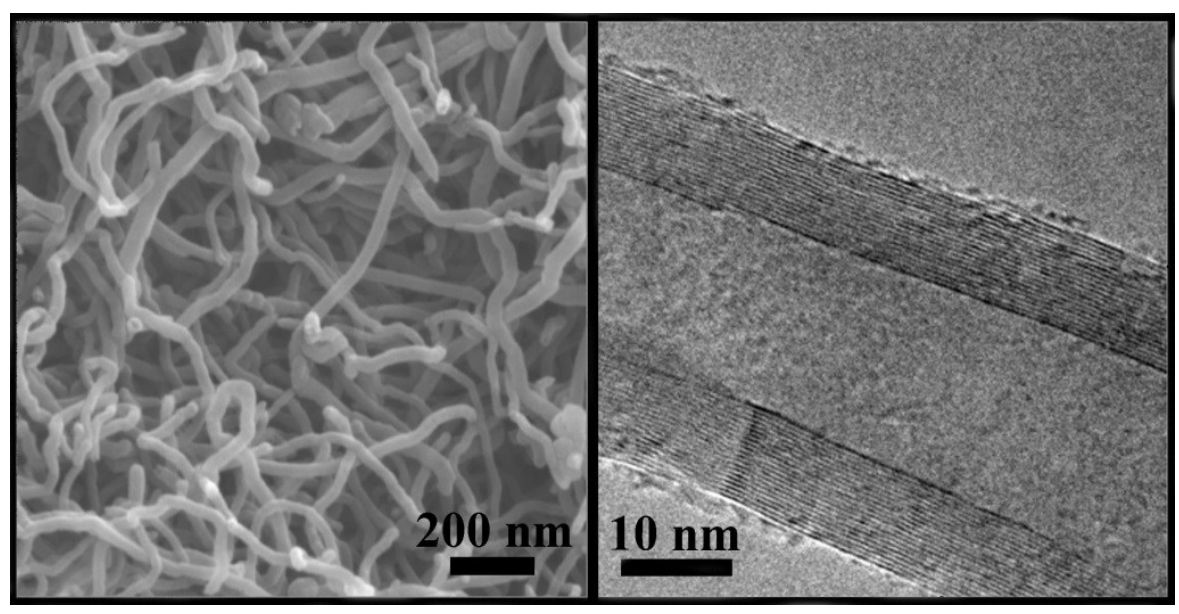

2.12. ábra: többfalú szén nanocsövek halmaza SEM (balra), és egyetlen cső nagy felbontású TEM felvétele (jobbra), ahol az egymásba ágyazott csőfalak is jól láthatóak.

A szén nanocsövek előállítására alkalmas eljárás a széntartalmú gázok katalizátorok jelenlétében történő reagáltatása (Catalytic Chemical Vapor Deposition - CCVD). A jelen dolgozatban használt nanocsövek is ezzel a módszerrel készültek (4.2.2 fejezet). Az így elöállított MWCNT további kezelést igényel, melynek során sav jelenlétében először a katalizátor anyagot, majd a melléktermékként keletkező amorf szenet távolítjuk el, hogy minél tisztább terméket kapjunk. ${ }^{159}$

A szén nanocsövek nagy energiájú őrléssel történő kezelése, legyen az akár darabolás, funkcionalizálás ${ }^{160}$ vagy kompozit ${ }^{161}$ rendszerek építése, már 1999 óta kutatott terület. ${ }^{162,163}$ A malomban történő őrlés során egyrészt lehetőség nyílik a szén nanocsövek fizikai tulajdonságainak (pl.: Young-modulus) vizsgálatára, másrészt célzott tulajdonságokkal bíró terméket, például a nyitott végü nanocsöveket hozhatunk létre. ${ }^{164,165}$ Kompozit anyagok esetén a mátrix és az erősítő fázisok még jobb keverése és aprítása lehet cél, ami az előállított termék előnyös tulajdonságainak számát növelheti. ${ }^{166}$

A szén nanocsövek felhasználása szinte egyidős felfedezésükkel, mivel a kutatók gyorsan rájöttek, hogy kiváló katalizátorhordozók. ${ }^{167}$ Nagy fajlagos felületük miatt gáz adszorbensként is alkalmazhatók, ami például a hidrogéntárolás problémájának megoldásában vezetett részeredményekre. ${ }^{168}$ Ezek mellett erősítőanyagként és elektronikus kisülésgátlóként számos területen alkalmazzák őket. ${ }^{169}$ 


\subsubsection{Fém-oxid nanorészecskék}

A szenzorika számára előállított fém-oxid nanorészecskék félvezető tulajdonságúak. Előállításukra több módszer is létezik, melyek közül a szol-gél eljárás, ${ }^{170}$ a plazmával javított kémiai gőzleválasztás (PECVD), ${ }^{171}$ a fizikai gőzleválasztás (PVD), ${ }^{172}$ a lézerabláció ${ }^{173}$ és a nagy energiájú örlés ${ }^{174-176}$ a legfontosabbak. Ez utóbbi több szempontból is felkeltette a kutatók érdeklődését. Az őrléssel történő előállítás jelentősen környezetkímélőbb és gazdaságosabb a többi módszernél. A szintézisek során gyakran a reaktánsok mellett nincs szükség oldószerre vagy egyéb adalékanyagra. Az előállítás hozama is kimagasló, hiszen egy pár órás őrléssel és megfelelő eszközzel akár több száz gramm termék is előállítható.

Az ón-dioxid fehér, szilárd anyag. Vízben nem oldódik, de savakban és lúgokban igen. Gyakori alkalmazása annak köszönhető, hogy széles tiltott sávú n-típusú félvezető. Alkalmazzák például vanádium-oxiddal katalizátorként aromás vegyületek szintézisénél, kerámia mázakban, fényvédő és fehér színezőanyagként. ${ }^{177}$ Használják még polírozóporként üveg, ékszer, márvány vagy ezüst csiszolásakor. Üveg bevonatként is igen közkedvelt, hiszen a felületre felvitt $\mathrm{SnO}_{2}$ film javítja a kopásállóságot és erősíti az üveget. ${ }^{178}$ Hőszigetelt ablakokon a vastag $\mathrm{SnO}_{2}$ filmek visszaverik az infravörös sugarakat. Legfontosabb felhasználási területe mégis a gázszenzorként való alkalmazás, többek közt $\mathrm{CO}$ detektorokban, illetve gyúlékony gázoknál. ${ }^{179}$ Ennek alapja az, hogy a gázokat úgy érzékeli, hogy az elektromos vezetőképessége megnő, mikor a redukáló gázok adszorbeálódnak az érzékelő felszínén és lecsökken, ha oxidáló gázoknak tesszük ki.

Intenzíven kutatott terület ma a mágneses nanoméretű anyagok, ezek közül is kiemelten a ferritek előállítása mechanokémiai úton. ${ }^{180-184}$ Előnyös tulajdonságaik közé tartozik a nagy mágneses permeabilitás és ellenállás, melynek következménye a kis örvényáram-veszteség és a magas frekvenciákon való alkalmazhatóság. Kémiai összetételük szerint a ferritek a vas-oxid $\left(\mathrm{Fe}_{2} \mathrm{O}_{3}\right)$ különféle fém-oxidokkal képzett vegyületei. Általános képletük $\mathrm{MeFe}_{2} \mathrm{O}_{4}$, ahol Me valamilyen fémion, leggyakrabban Ni, Cr, Mg, Mn, Cd vagy Mg. ${ }^{185}$ Használják öket transzformátormagokban, rúdantennákban, vevőfejekben, mikrohullámú berendezésekben, háztartási elektronikai berendezésekben és számítógépekben is. Előfordulnak még nagyérzékenységű szenzorokban, kondenzátorokban, lítium elemekben, valamint mágneses folyadékok és kerámia mágnesek alkotóiként is. A nikkel ferrit $\left(\mathrm{NiFe}_{2} \mathrm{O}_{4}\right)$ az egyik legsokoldalúbban felhasználható lágymágneses tulajdonságú ferrit. 
A fém-oxidok mechanokémiai előállítására alapvetően két módszer áll rendelkezésünkre: 1) Fém-oxid porokat egy másik elemi fémmel örlünk össze, így hozva létre a kívánt terméket; 2) a fémet valamely sójából oxidáció vagy cserebomlás révén állítjuk elő. Ehhez természetesen szükségünk van megfelelő reakciópartnerre, ami őrléseknél általában $\mathrm{NaOH}^{186-188}$ vagy $\mathrm{Na}_{2} \mathrm{CO}_{3}{ }^{189,190}$. Utóbbinak megvan az az előnye, hogy bomlása közben $\mathrm{CO}_{2}$ szabadul fel, ami a reakció kinetikájának követésére ad lehetőséget (lásd: 4.2.1. fejezet). A reaktánsok mellett szinte minden esetben $\mathrm{NaCl}$ mátrixot használunk ${ }^{190-192}$ A mátrixnak több funkciója is van a szintézis során. Gyakran elöfordul például, hogy az őrlendő anyagból nem áll rendelkezésünkre elegendő mennyiség. Ha ezt önmagában őrölnénk meg, akkor a kitapadás miatt akár az összes anyagunkat is elveszthetnénk. Ilyenkor a mátrix anyagában felvett őrlemény már könnyebben kezelhető és a kitapadási veszteség is megoszlik a két anyag arányában. A mátrix dörzsölő hatása a kitapadt anyagmennyiséget csökkenti, így a NaCl-nál keményebb anyagot $\left(\mathrm{pl} .: \mathrm{SiO}_{2}\right)$ is használhatunk, bár ez növelheti az örlemény elszennyeződését. A mátrix másik fontos szerepe, hogy a mechanokémiai reakciókhoz elegendő felületet biztosít. A $\mathrm{NaCl}$ köbös kristályain kialakuló nanokristályok növekedésének az is határt szab, hogy korlátozott az egy térrészben levő prekurzorok mennyisége. Emellett a mátrix közvetíti a golyók energiáját is, hiszen azok nem találkozhatnak közvetlenül az összes, a rendszerben lévő anyagszemcsével. A segédanyaggal szemben támasztott követelmények: az első és legfontosabb, hogy ne lépjen reakcióba se a kiindulási anyagokkal, se a termékkel; a második, hogy legyen olyan módszerünk, mellyel a terméket el tudjuk választani az őrlés végén a mátrix anyagától.

\subsubsection{Titanát szerkezetek}

A titán-dioxid $\left(\mathrm{TiO}_{2}\right)$ önmagában és titanát szerkezetek alapanyagaként is széles körben használt vegyület. Nagy fényvisszaverő képessége miatt a fehérfesték-gyártás első számú pigmentanyaga. Nanoméretü részecskéit UV-szürőként kozmetikai készítményekben alkalmazzák. ${ }^{193}$ Félvezető oxidként alkalmas számos gáz detektálására akár magas hőmérsékleten is. ${ }^{194}$ Emellett jó fotokatalizátor, melynek köszönhetően ma is intenzíven kutatott az ilyen irányú felhasználása. ${ }^{195}$

A természetes titán-dioxidnak négy polimorf módosulata létezik. Ezek a rutil, az anatáz, a brookit és a nagyon ritka „akaogiite” vagy $\mathrm{TiO}_{2}$-B. ${ }^{196}$ A négy kristályforma közül gyakoriságuk és előállíthatóságuk miatt főként az első kettőt használják. A rutil keskenyebb tiltott sávja miatt szélesebb spektrumon képes a fényt elnyelni, míg az anatáz hatékonyabb 
fotokatalizátor. $\mathrm{Az}$ anatáz $600{ }^{\circ} \mathrm{C}$-on rutillá alakul, miközben fotokatalitikus aktivitása csökken. A két módosulat speciális arányú (anatáz : rutil - $3: 1$ ) keveréke ma referencia anyagnak számít fotokatalizátorok aktivitásának vizsgálatakor. Ez a Degussa-P25. ${ }^{197}$

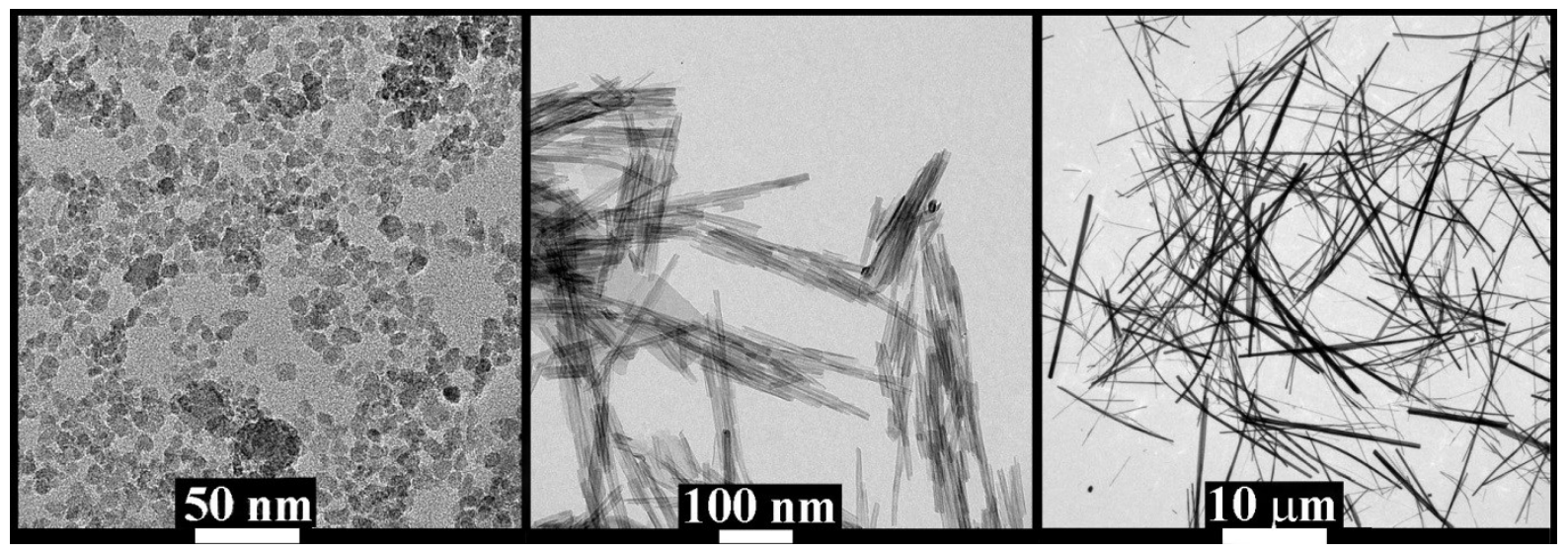

2.13. ábra: Titanát szerkezetek TEM képei. Balról jobbra: $\mathrm{TiO}_{2}$ nanorészecskék;

Trititanát nanocsövek; Trititanát nanoszálak.

A titán-dioxid az építőköve az egydimenziós titanát szerkezeteknek. Ide tartoznak a mára sokféleképpen előállítható trititanát nanocsövek (TiONT) és nanoszálak (TiONW). A csövek 10 nm átméröjü, maximum néhány száz nanométer hosszú szerkezetek. Ezek rendeződésével és összekristályosodásával alakulnak ki a nanoszálak, melyek egy teljes nagyságrenddel nagyobbak, mintegy 50-150 nm átmérő és széles skálán mozgó hossz (1-50 $\mu \mathrm{m})$ jellemzi őket (2.13. ábra). A termék összetétele és minősége nagyban függ a szintézis módjától. Az általunk vizsgált nanoszálak a Kasuga és társai által kidolgozott eljárással ${ }^{198}$ készültek tömény $\mathrm{NaOH}$ oldatban, hidrotermális körülmények között $125{ }^{\circ} \mathrm{C}$ hőmérsékleten. A termék összegképlete $\mathrm{H}_{2} \mathrm{Ti}_{3} \mathrm{O}_{7}$. A nanocsövek szintézise hasonló módon, rövidebb reakcióidő mellett és alacsonyabb hőmérsékleten, szintén tömény, $10 \mathrm{M}$-os $\mathrm{NaOH}$ közegben történik. A trititanát nanoszálakat és nanocsöveket többek között fotoelektromos cellák érzékenyítésére szenzorként (pl. CO érzékelés arannyal módosított trititanát nanoszálakkal) és katalizátorhordozóként alkalmazzák. ${ }^{199-201}$ 


\section{Célkitüzés}

Doktori munkám célja az volt, hogy bővítsem a nanoszerkezetek mechanokémiai előállításával kapcsolatos ismereteket. Három konkrét részterületen végeztem vizsgálatokat:

1) az őrlési energia Burgio-Rojac modell segítségével végzett számításának helyességigazolása nanoszerkezetekre,

2) egy elterjedt mechanokémiai nanorészecske előállítási módszer használatakor tapasztalható látszólagos anomália magyarázata,

3) csak nagy energiájú őrléssel megvalósítható speciális nanorészecske szintézisek körének bővítése.

A tervezhető mechanokémia fejlesztése szempontjából kulcskérdés, hogy a reaktánsokkal közölt energia számítható legyen, mivel ez minden gyakorlati léptéknövelési probléma alapja. Doktori munkám során kiderült, hogy a területen általánosan elfogadott Burgio egyenlet nanorészecskék őrlésére való alkalmazhatóságát még sohasem bizonyították. Az Alkalmazott és Környezeti Kémiai tanszéken évtizedek óta kutatott szén nanocsövek ideális modellrendszernek tűntek az egyenlet helyességigazolására, ezért munkám első része ezt a vizsgálatsorozatot tárgyalja.

$\mathrm{Az} \mathrm{SnO}_{2}$ nanorészecskék $\mathrm{SnCl}_{2}$ és $\mathrm{Na}_{2} \mathrm{CO}_{3}$-ból történő mechanokémiai elöállítása közben, a reakció kinetikájának vizsgálatára használt $\mathrm{CO}_{2}$ nyomás-idő függvénye a várttól lényegesen eltérőnek mutatkozott. Részletes kísérletsorozattal bizonyítottuk azt a hipotézisünket, hogy a váratlan nyomásesés oka a $\mathrm{Na}_{2} \mathrm{CO}_{3}$ reakciópartner $\mathrm{CO}_{2}$-csapdázó képessége. A szakirodalom nem tárgyalta ezt az anomáliát, holott jelentős hibát véthetünk miatta a kinetikai mérések értelmezésekor.

Végezetül munkám célja volt az is, hogy a megszerzett elméleti és gyakorlati ismereteket konkrét mechanokémiai nanorészecske szintézisben hasznosítsam. Ehhez a $\mathrm{Na}_{2} \mathrm{CO}_{3}$-os előállítási módszert kiterjesztettem más fém-oxidokra is, továbbá sikerült egy korábban ismeretlen, mechanokémiai trititanát nanocső előállítási módszert találnom.

Összességében tehát igyekeztem mind elméleti mind gyakorlati eredményekkel alátámasztani a mechanokémiai eljárások létjogosultságát a nanotechnológiában egyrészt azáltal, hogy bemutatom több nanostrukturált anyag előállítási lehetőségét, másrészt azáltal, hogy javítom az eljárás alkalmazhatóságát és modellezhetőségét az egyes változók hatásának vizsgálatával. 


\section{Kísérleti rész}

\subsection{Felhasznált anyagok}

(név/képlet/forgalmazó)

Fém-oxid nanorészecskék előállításához felhasznált anyagok:

- Kadmium(II)-klorid

- Króm(II)-klorid

- Mangán(II)-klorid

- Nátrium-karbonát

- Nátrium-klorid

- Nikkel(II)-klorid

- Ólom(II)-klorid

- Ón(II)-klorid,

- $\quad \operatorname{Vas}(\mathrm{III})-k l o r i d$

$$
\begin{gathered}
\mathrm{CdCl}_{2} \cdot 5 \mathrm{H}_{2} \mathrm{O} \\
\mathrm{CrCl}_{2} \cdot 6 \mathrm{H}_{2} \mathrm{O} \\
\mathrm{MnCl}_{2} \cdot 4 \mathrm{H}_{2} \mathrm{O} \\
\mathrm{Na}_{2} \mathrm{CO}_{3} \\
\mathrm{NaCl} \\
\mathrm{NiCl}_{2} \cdot 6 \mathrm{H}_{2} \mathrm{O} \\
\mathrm{PbCl}_{2} \\
\mathrm{SnCl}_{2} \cdot 2 \mathrm{H}_{2} \mathrm{O} \\
\mathrm{FeCl}_{3} \cdot 6 \mathrm{H}_{2} \mathrm{O}
\end{gathered}
$$

Molar Chemicals Kft.

Sigma-Aldrich Kft.

Sigma-Aldrich Kft.

Sigma-Aldrich Kft.

Sigma-Aldrich Kft.

Sigma-Aldrich Kft.

Sigma-Aldrich Kft.

Sigma-Aldrich Kft.

Sigma-Aldrich Kft.

Szén nanocsövekkel végzett kísérletekhez használt anyagok:

- Acetilén

- Alumínium-oxid

$\mathrm{C}_{2} \mathrm{H}_{2}$

- Kálium-hidroxid

$\mathrm{Al}_{2} \mathrm{O}_{3}$

- Kobalt(II)-nitrát

- Nátrium-hidroxid

- Nitrogén

- Sósav

$\mathrm{KOH}$

$$
\begin{gathered}
\mathrm{Co}\left(\mathrm{NO}_{3}\right)_{2} \cdot 6 \mathrm{H}_{2} \mathrm{O} \\
\mathrm{NaOH} \\
\mathrm{N}_{2}
\end{gathered}
$$

$\mathrm{HCl}$

- Vas(III)-nitrát$$
\mathrm{Fe}\left(\mathrm{NO}_{3}\right)_{3} \cdot 9 \mathrm{H}_{2} \mathrm{O}
$$

Messer Hungary Kft.

Sigma-Aldrich Kft.

Molar Chemicals Kft.

Sigma-Aldrich Kft.

Molar Chemicals Kft.

Messer Kft.

Molar Chemicals Kft.

Sigma-Aldrich Kft.

Titanát szerkezetekkel végzett kísérletekhez használt anyagok:

- Abszolút etanol

- Nátrium-hidroxid

- Nátrium-karbonát

- Nátrium-klorid

- Sósav

- Titán-dioxid

- Titán-klorid

$$
\begin{gathered}
\mathrm{C}_{2} \mathrm{H}_{5} \mathrm{OH} \\
\mathrm{NaOH} \\
\mathrm{Na}_{2} \mathrm{CO}_{3} \\
\mathrm{NaCl} \\
\mathrm{HCl} \\
\mathrm{TiO}_{2} \\
\mathrm{TiCl}_{4}
\end{gathered}
$$

Molar Chemicals Kft.

Sigma-Aldrich Kft.

Sigma-Aldrich Kft.

Sigma-Aldrich Kft.

Molar Chemicals Kft.

Sigma-Aldrich Kft.

Sigma-Aldrich Kft. 


\subsection{Szintézisek bemutatása}

4.2.1 A Fritsch Pulverisette 6 (FP6) bolygó golyósmalom és a GTM-II rendszer

Az őrlési kísérleteket egy FP6 bolygó golyósmalommal végeztük el (4.1. ábra). Ez a típus egyszerre egy őrlőedény befogadására képes. Fordulatszáma 100 és 650 fordulat/perc (rpm) között változtatható $10 \mathrm{rpm}$ fokozatonként. A malom képes 80, 250 és $500 \mathrm{~mL}$ térfogatú őrlőedények befogadására, melyeket egy biztonsági zárral rögzíthetünk. Az őrlőedény maximális súlya $8 \mathrm{~kg}$ lehet. Ez az excentrikus tengely elhelyezkedése miatt a növekvő fordulatszámmal egyre nagyobb egyensúlyvesztést eredményez, ami a berendezés jelentős rázkódásához vezetne. Emiatt az őrlőedény befogószerkezetével szemben egy menetes tengelyre szerelt ellensúlyt találunk. Az ellensúlyt az alaplemez tengelyétől távolabb állítva egyre nagyobb tömeget képes kiegyensúlyozni, így meggátolva a rázkódást.

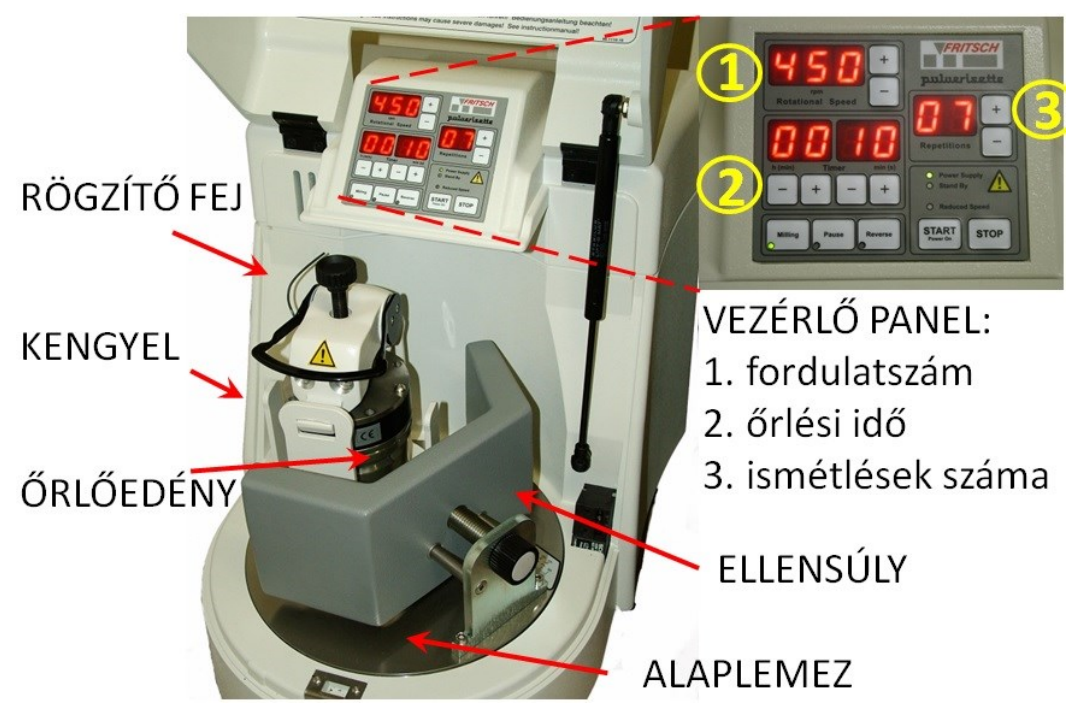

4.1. ábra: a Fritsch Pulverisette 6 típusú bolygó golyósmalom felépítése. Jobboldalt a malom felső részén található vezérlő panel látható kiemelve.

Az „ismétlések száma” az örlési idő több szakaszra való felbontását teszi lehetővé. Ennek nagy szerepe van a minta megfelelő átkeverésében, valamint megakadályozza az anyag őrlőfalra és az őrlőgolyókra való túlzott kitapadását. Mivel az egyes ismétlési periódusokban az őrlőedény forgási iránya ellentétes, a golyók megváltozott futásiránya jobban átkavarja az őrleményt és sok kitapadt anyagot visszajuttat abba. A rögzítőfej és kengyel az őrlőedény helyben tartására szolgálnak. A malom ajtaja biztonsági zárral ellátott, így őrlés közben nem lehetséges felnyitni azt. 
Kísérleteink során a következő őrlőedényeket és hozzájuk tartozó golyókat alkalmaztuk: 80 és $250 \mathrm{~mL}$ térfogatú $\mathrm{Fe}-\mathrm{Ni}-\mathrm{Cr}$ rozsdamentes acél tégely 5 és $10 \mathrm{~mm}$ átméröjü őrlőgolyókkal, valamint egy $80 \mathrm{~mL}$ térfogatú $\mathrm{Si}_{3} \mathrm{~N}_{4}$ tégely $10 \mathrm{~mm}$ átméröjü golyókkal.

Az örlések során lehetőségünk volt a reakciók kinetikájának követésére. Ezt a Fritsch GmbH által gyártott, az örlőedény tetejére rögzíthető GTM-II (Gas pressure and Temperature Measuring system $)^{202}$ detektorrendszerrel végeztük el. Ebben a gyártó $0,1{ }^{\circ} \mathrm{C}$ pontosságú hőmérséklet- és $0,1 \mathrm{kPa}$ pontosságú nyomásdetektort helyezett el. A müszer 0,5-30 másodperces időfelbontással képes mérni ezeket az adatokat, alkalmas tehát az őrlőedényben uralkodó aktuális nyomás- és hőmérsékletviszonyok in situ mérésére, és rádióhullámok segítségével történő továbbítására (4.2. ábra).

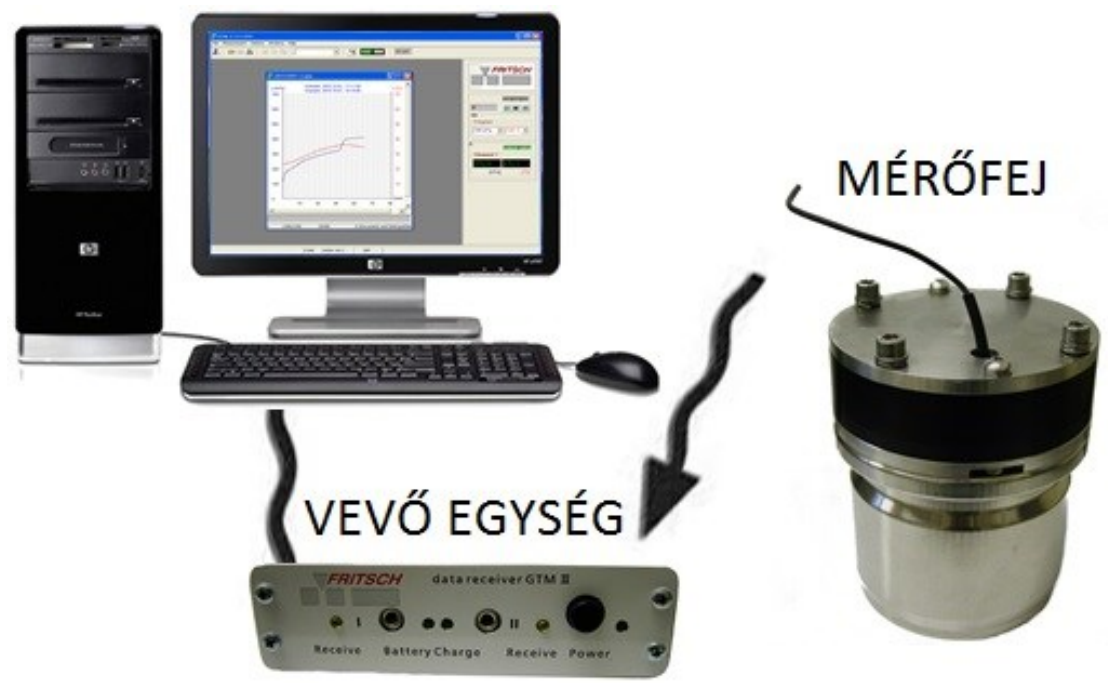

4.2. ábra: a hőmérséklet- és nyomásdetektáló GTM-II rendszer mérőfeje (az őrlődob tetejére rögzítve) és vevőegysége.

A vevőegység össze van kapcsolva egy számítógéppel, amely azonnal grafikonon ábrázolja a változásokat, valamint számadatokkal kijelzi a pillanatnyilag mért értékeket. Amennyiben az őrlés során gázképződéssel járó reakció játszódik le, úgy a nyomás változásából a reakció kinetikájára tudunk következtetni. Emellett a hőmérsékletváltozásból is fontos információhoz juthatunk, hiszen mind exoterm, mind endoterm folyamatok jól követhetőek a rendszerrel. ${ }^{202-204}$ Gázképződéssel járó reakció vizsgálatakor a hőmérséklet- és nyomásadatok ismeretében az egyetemes gáztörvényt alkalmazva kiszámolhatjuk adott időpillanatban egy reaktáns konverziójának értékét (11-12). Ehhez először meghatározzuk a 100\%-os konverzióhoz tartozó keletkező gáz anyagmennyiségét $\left(n_{g a ́ z}\right)$. Ezután a GTM program által megjelenített aktuális nyomás- és hőmérsékletadatokat felhasználva az 
őrlőedényben az adott pillanatban jelen levő gáz anyagmennyisége $\left(n_{G T M}\right)$ számolható $(11)$. A leolvasott nyomásértékből $\left(p_{G T M}\right)$ ki kell vonni a légköri nyomást $\left(p_{0}\right)$, mivel a helyes kalkulációhoz csak a képződő gáz parciális nyomására van szükségünk. Ezután az őrlőedény szabad térfogatát határozzuk meg, ami nem egyenlő a gyártó által megadott 250 mL-rel, mivel azt korrigálni kell a golyók $\left(\Sigma V_{b}\right)$ és a bemért őrlemény $\left(V_{m}\right)$ által elfoglalt térfogattal. A szintén a GTM programból leolvasott aktuális hőmérséklet adat $\left(T_{G T M}\right)$ ismeretében az „, $\mathrm{n}_{\mathrm{GTM}}$ ” már számolható. A konverzió $(K)$ százalékos értékét a felszabaduló gáz aktuális és végső anyagmennyiségének hányadosa adja meg (12).

$$
\begin{gathered}
n_{G T M}=\frac{\left[p_{G T M}-p_{0}\right] \times\left[V_{v}-\left(\sum V_{b}+V_{m}\right)\right]}{R \times T_{G T M}} \\
K(\%)=\frac{n_{G T M}}{n_{g a ́ z}} \times 100 \\
K(\%)=\frac{p_{G T M_{k o r r}}}{p_{C O_{2}}} \times 100
\end{gathered}
$$

Még gyorsabban eredményt kapunk, ha a légköri nyomással korrigált $\left(p_{G T M_{k o r r}}\right)$ aktuális nyomást és az elöre kalkulált $\mathrm{CO}_{2}$ okozta maximális nyomásadatok $\left(p_{\mathrm{CO}_{2}}\right)$ hányadosát számoljuk (13).

Ez az egyszerü számítási mód nem veszi figyelembe a felszabaduló gáz reális viselkedését, ezért eredménye csak közelítésnek tekinthető. Noha a reális gázokra alkalmazható állapotegyenletekkel (pl. van der Waals-egyenlet) a számítást pontosíthatnánk, a tapasztalatok szerint a tökéletes gáz közelítés az általunk vizsgált nyomás- és hőmérséklettartományban megfelelő. A két számítási módszer eltérését az általunk vizsgált hőmérséklet- és nyomástartományban a 4.1. táblázat szemlélteti. A tökéletes és reális gázokra számolt anyagmennyiségek különbsége átlagosan $1,23 \%$ volt. 


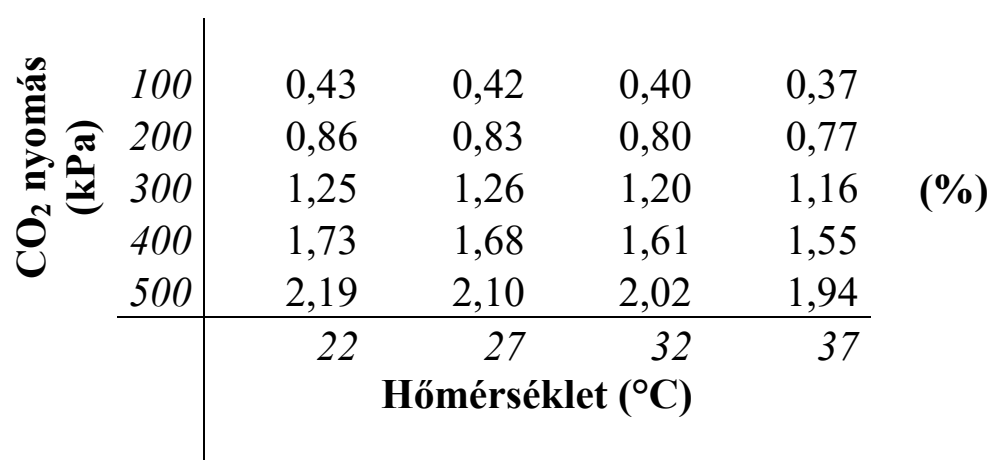

4.1. táblázat: $\mathrm{CO}_{2}$ anyagmennyiségének százalékos eltérése az általunk vizsgált nyomás- és hőmérsékletviszonyok között a tökéletes gáz közelítést és a reális gázok van der Waals állapotegyenletét alkalmazva.

A GTM nyomáskövetés fő előnye, hogy segítségével kiválthatjuk egy rendszer konverzió-optimalizálásának hosszadalmas módszerét, melynek során többször mintát kéne vennünk az őrleményből, majd azt valamilyen analitikai módszerrel vizsgálnunk kellene, míg abban a termék akkora mennyiségben lesz kimutatható, mint amennyit a reakció tervezésénél célul tűztünk ki. Ehelyett (első közelítésben) elegendő a nyomás-idő diagramot figyelni, és az elvárt konverziónak megfelelő nyomásnál az őrlést leállítani.

\subsubsection{Szén nanocsövek elöállítása és őrlése}

A többfalú szén nanocsöveket katalitikus kémiai leválasztással állítottuk elő acetilén-nitrogén gázelegyből, $\mathrm{MgO}$ hordozós vas-kobalt katalizátorral, $700{ }^{\circ} \mathrm{C}$-on csőkemencében. A terméket tömény sósavas kezelés után desztillált vízzel 7-es pH-ig mostuk. ${ }^{159}$

Kiemelten fontos volt a kísérletek során használt őrlőedény anyagának helyes megválasztása, ezért három különböző dobot is kipróbáltunk. Ezek a $\mathrm{Si}_{3} \mathrm{~N}_{4}$ (szilícium-nitrid), a később alkalmazott Fe-Ni-Cr rozsdamentes acél, és a WC (volfrám-karbid) voltak. Ezek sürüsége rendre $3,25 \mathrm{~g} / \mathrm{cm}^{3} ; 7,8 \mathrm{~g} / \mathrm{cm}^{3} ; 14,95 \mathrm{~g} / \mathrm{cm}^{3}$. A volfrám-karbid edényben nagyon gyorsan törtek a szén nanocsövek, ami nem tette volna lehetővé a megfelelő időfelbontású adatsor készítését. $\mathrm{A} \mathrm{Si}_{3} \mathrm{~N}_{4}$ edényben az MWCNT hossza csak nagyon lassan változott, így ahhoz, hogy mérhető különbségeket kapjunk, az örlések nagyon hosszú ideig tartottak volna. E tapasztalatok alapján választottuk ki a Fe-Ni-Cr rozsdamentes acéldobot.

Az előállított MWCNT-vel vizsgáltuk az őrlés paramétereinek hatását a nanocsövek darabolódásra. Ehhez azért választottuk az MWCNT-ket, mert nagy rugalmassági együtthatóval (Young-modulus) rendelkeznek ${ }^{205}$, így széles határokon belül tudtuk változtatni az egyes paraméterek értékét. Emellett a tanszéken már korábban is folytak hasonló 
kísérletek $^{164,}{ }^{206}$, melyek eredményeire támaszkodva ezt a vizsgálatot pontosabban megtervezhettük. Az őrlések után az MWCNT-t mindenféle utókezelés nélkül vizsgáltuk, hogy a tapasztalt eredmény kizárólag a mechanikai hatásnak legyen tulajdonítható.

\subsubsection{Fém-oxid nanorészecskék előállítása}

Több kutatócsoporttal együtt dolgozva fém-oxid nanorészecskéket állítottunk elő, mint például ón-dioxidot $\left(\mathrm{SnO}_{2}\right)$, nikkel-oxidot $(\mathrm{NiO})$, nikkel-ferritet $\left(\mathrm{NiFe}_{2} \mathrm{O}_{4}\right)$, mangán-oxidot $\left(\mathrm{MnO}_{2}\right)$, kadmium-oxidot $(\mathrm{CdO})$, vas-oxidot $\left(\mathrm{Fe}_{2} \mathrm{O}_{3}\right)$ és króm-oxidot $\left(\mathrm{CrO}_{\mathrm{x}}\right)$. A GTM rendszer előnyeit kihasználva minden esetben $\mathrm{Na}_{2} \mathrm{CO}_{3}$-t használtunk reakciópartnerként. Amennyiben szükséges volt, a terméket további kezelésnek vetettük alá: adott hőfokon levegőn hőkezeltük, majd desztillált vízzel mostuk. Minden szintézis során $\mathrm{NaCl}$ mátrixot alkalmaztunk.

\subsubsection{Egyszerü fém-oxid nanorészecskék elöállitása}

$\mathrm{Az}$ eljárást az ón-dioxid példáján mutatom be részletesen. $\mathrm{Az} \mathrm{SnO}_{2}$ nanorészecskéket két lépésben állítottuk elő. A malomban először $6,77 \mathrm{~g} \mathrm{SnCl}_{2} \cdot 2 \mathrm{H}_{2} \mathrm{O}$ és $3,18 \mathrm{~g} \mathrm{Na}_{2} \mathrm{CO}_{3}$ reaktánsokból ón(II)-oxid (SnO) képződik (14), melyet $600{ }^{\circ} \mathrm{C}$-on kiégetve kapjuk meg az $\mathrm{SnO}_{2}-\mathrm{t}(15)$.

$$
\begin{gathered}
\mathrm{SnCl}_{2}+\mathrm{Na}_{2} \mathrm{CO}_{3}=\mathrm{SnO}+2 \mathrm{NaCl}+\mathrm{CO}_{2} \\
2 \mathrm{SnO}+\mathrm{O}_{2}=2 \mathrm{SnO}_{2}
\end{gathered}
$$

Hőkezelés után a mintákat desztillált vízzel mostuk, majd $80{ }^{\circ} \mathrm{C}$-on szárítószekrényben vízmentesre szárítottuk. Az egyes anyagok bemérésénél figyelemmel kellett lenni azok sorrendjére, mivel a kristályvizes ón-klorid a nátrium-karbonáttal reakcióba léphetnek egymással mechanikai hatás nélkül is. Így erre ügyelve az őrlőedénybe a két reaktáns közé a NaCl-t mértük be, ezzel megakadályozva, hogy a két anyag még az őrlés kezdete előtt érintkezzenek. Ezt az összeállítási sorrendet alkalmaztuk a többi fém-oxid nanorészecske szintézisekor is.

A NiO (16) nanorészecskéket egy lépésben állítottuk elő.

$$
\mathrm{NiCl}_{2}+\mathrm{Na}_{2} \mathrm{CO}_{3}=\mathrm{NiO}+2 \mathrm{NaCl}+\mathrm{CO}_{2}
$$

7,13 $\mathrm{g} \mathrm{NiCl}_{2} \cdot 6 \mathrm{H}_{2} \mathrm{O}$ és $3,18 \mathrm{~g} \mathrm{Na}_{2} \mathrm{CO}_{3}$ bemérése után az örlést az előre kiszámolt, teljes fémsó konverziójának megfelelő idő elérése után még további 2 órán át folytattuk. Ezután 
desztillált vizes mosással távolítottuk el a bemért és keletkezett nagy mennyiségü NaCl-t és az esetleges maradék prekurzorokat. Végül szárítószekrényben $80{ }^{\circ} \mathrm{C}$-on egy éjszakán át szárítottuk a terméket.

$\mathrm{MnO}_{2}, \mathrm{CdO}$ és $\mathrm{CrO}_{\mathrm{x}}$ nanorészecskéket a fentiekhez hasonlóan, az egyes fémek kristályvizes klorid sóiból $\left(\mathrm{MnCl}_{2} \cdot 4 \mathrm{H}_{2} \mathrm{O}, \mathrm{CdCl}_{2} \cdot 6 \mathrm{H}_{2} \mathrm{O}, \mathrm{CrCl}_{3} \cdot \mathrm{H}_{2} \mathrm{O}\right) \mathrm{NaCl}$ mátrixban $\mathrm{Na}_{2} \mathrm{CO}_{3}$ reaktánssal állítottuk elő. A mintákat hőkezeltük, majd desztillált vizes mosás után szárítószekrényben $\left(80^{\circ} \mathrm{C}\right)$ szárítottuk.

$\mathrm{TiO}_{2}$ nanorészecskéket (TiONP) is elöállítottunk 6,33 $\mathrm{g} \mathrm{TiCl}_{4}$ és 3,54 $\mathrm{g} \mathrm{Na}_{2} \mathrm{CO}_{3}$ reaktánsból az alábbi reakcióegyenlet alapján (17):

$$
\mathrm{TiCl}_{4}+2 \mathrm{Na}_{2} \mathrm{CO}_{3}=\mathrm{TiO}_{2}+2 \mathrm{CO}_{2}+4 \mathrm{NaCl}
$$

Az előállított TiONP-ket szintézis után tömény sósavval, majd desztillált vízzel mostuk. Ebből TiONT-t $110{ }^{\circ} \mathrm{C}$-on 20 órán át keverés nélkül zárt autoklávban állítottuk elő $10 \mathrm{M}$ nátrium-hidroxid oldatban.

\subsubsection{A nikkel-ferrit nanorészecskék elöállitása}

A nikkel-ferrit nanorészecskék szintézisét egy lépésben végeztük el a reakcióegyenlet szerint:

$$
\mathrm{NiCl}_{2}+2 \mathrm{FeCl}_{3}+4 \mathrm{Na}_{2} \mathrm{CO}_{3}=\mathrm{NiFe}_{2} \mathrm{O}_{4}+8 \mathrm{NaCl}+4 \mathrm{CO}_{2}
$$

A részecskék előállítása alapvetően nem különbözött az egyszerü fém-oxidoknál leírtaktól. A 2,37 $\mathrm{g} \mathrm{NiCl}_{2} \cdot 6 \mathrm{H}_{2} \mathrm{O}, 5,46 \mathrm{~g} \mathrm{FeCl}_{3} \cdot 6 \mathrm{H}_{2} \mathrm{O}$ és 4,23 $\mathrm{g} \mathrm{Na}_{2} \mathrm{CO}_{3}$ prekurzor ôrlése után desztillált vízzel mostuk a mintákat, majd egy éjszakára $80{ }^{\circ} \mathrm{C}$-os szárítószekrénybe helyeztük őket.

\subsubsection{Trititanát nanoszálak előállítása és őrlése}

A trititanát nanoszálakat az Alkalmazott és Környezeti Kémiai tanszéken egy már régóta alkalmazott módszer szerint állítottuk elő. ${ }^{207}$ Titán-dioxidhoz (anatáz) $10 \mathrm{M} \mathrm{NaOH}$ oldatot adtunk, majd a rendszert zárt, teflonbéléses autoklávban $125{ }^{\circ} \mathrm{C}$-on $28 \mathrm{rpm}$ sebességgel 48 órán át forgattuk. Hütés és szürés után $\mathrm{pH}=8$ értékig mostuk desztillált vízzel, majd $80{ }^{\circ} \mathrm{C}$-on szárítottuk. A TiONW mintát ezután különböző $E_{b}$ és $E_{c u m}$ mellett megőröltük. 
Ehhez mind a $\mathrm{Si}_{3} \mathrm{~N}_{4}$, mind a $80 \mathrm{~mL}$-es rozsdamentes acél őrlődobot kipróbáltuk, az energiákat pedig a fordulatszám és az őrlési idő változtatásával szabályoztuk.

\subsection{Vizsgálati módszerek}

A nanoméretü anyagok jellemzéséhez elengedhetetlen vizsgálati módszer az elektronmikroszkópia. A technika lehetővé teszi az előállított anyagok morfológiájának és kristályos szerkezetének tanulmányozását. Mintáinkat az azonosítás és a tulajdonságaikban bekövetkező változások követése érdekében számos analitikai módszerrel jellemeztük. Ezeket röviden a következőkben mutatom be.

\subsubsection{Transzmissziós elektronmikroszkópia (TEM) és elektrondiffrakció (ED)}

A transzmissziós elektronmikroszkóp képes szubnanométeres laterális felbontásra a minta egy igen kis vastagságú (néhány, legfeljebb néhányszor tíz nanométer) részletében, így kiválóan alkalmas a nanoméretű anyagok vizsgálatára. Sok szempontból analóg az áteső fényt alkalmazó optikai mikroszkóppal, mivel a mintán áthaladó elektronokkal képalkotó lencsék segítségével, valódi, nagyított képet állítunk elő. A mikroszkópban egy elektronforrás (katód) segítségével elektronnyalábot állítunk elő, amit gyorsítunk és egy elektromágneses lencserendszer segítségével a mintára irányítunk. A képalkotás során, a minta anyagán áthaladó (transzmittált) elektronok egy fluoreszcens ernyőre vagy egy CCD kamerára vetülnek. Nagy felbontású üzemmódban közvetve megfigyelhetőek a kristályos minták anyagát felépítő kristálysíkok is (amennyiben azok a direktsugár tengelyével párhuzamosan orientáltak). A TEM kiegészítő anyagvizsgálati technikája az elektrondiffrakció, ahol a képalkotáshoz csak a diffraktált elektronokat használjuk. Az ED a szilárd testek atomi rétegeiről szóródó elektronokból kialakuló interferenciaképet mutatja, ami információt ad a vizsgált anyag kristályszerkezetéről. A kristálydiffrakciót leíró Bragg-egyenlet alapján meghatározhatjuk a rácsállandót is.

Mintáinkat egy FEI Tecnai $\mathrm{G}^{2}-20$ X-Twin típusú, 200 kV gyorsítófeszültségü elektronmikroszkóppal vizsgáltuk. Az egyes minták etanolos szuszpenzióját egy szénhártyával bevont réz rostély hordozóra (grid) cseppentettük fel.

\subsubsection{Pásztázó elektronmikroszkópia (SEM)}

A pásztázó elektronmikroszkópiás mérések során egy elektronforrásból (katód) származó elektronnyalábot gyorsítunk és a minta irányába vezetünk. A gyorsított elektronokat 
egy elektromágneses lencserendszerrel fókuszáljuk. A fókuszált (ideálisan szubnanométer átmérőjü) nyalábbal pontról pontra végigpásztázzuk a minta vizsgált területét, ahol az elektronnyaláb kölcsönhatásba lép a minta anyagával. A kölcsönhatás közben többféle jel keletkezik, melyeket a megfelelő detektorral és egy számítógépes apparátus segítségével rekonstruálva előáll a kép. A kép információtartalma nagyban függ a detektált jel minőségétől. Képalkotásra leggyakrabban a szekunder elektronokat (SE) hasznosítjuk. Ezek az elektronok a minta anyagának legfelső néhány nanométer mély rétegéből származnak és általuk nagy felbontású képek készíthetők a minta felszínéről. Az így készült kép kontrasztját legnagyobb részt a minta felszínének egyenetlenségei, topográfiai viszonyai szolgáltatják (kisebb részt rendszámkontrasztos képet szolgáló, az SE detektorba véletlenszerüen jutó visszaszórt (BSE) elektronok). A SEM-ben a minta anyagával szemben támasztott fontos kívánalom, hogy annak elektromosan vezetőnek kell lennie. A szigetelő minták felszínét vezetővé kell tenni. Erre több módszer létezik, tanszékünkön aranygőzöléses technika érhető el, mellyel 3-4 nm vastagságú vezető bevonatot hozunk létre a minta felszínén.

SEM vizsgálatainkat egy Hitachi gyártmányú S-4700 Type-II hideg téremissziós pásztázó elektronmikroszkóppal végeztük el $10 \mathrm{kV}$ gyorsítófeszültség és $10 \mathrm{~mA}$ mintaáram alkalmazásával. Az elektromosan nem vezető mintákat egy NanoQuorum SC7620 készülékkel 60 s-ig 18 mA plazmaáram alkalmazásával aranyoztuk.

\subsubsection{Röntgen diffraktometria (XRD)}

Az XRD olyan szerkezetvizsgáló módszer, ami az anyagunk kristályos állapotáról, az abban található kristályos fázisok fajtájáról és azok mennyiségéről szolgáltat információt. A vizsgálat során a mintát monokromatikus röntgenforrással világítjuk meg, így az erősítő és gyengítő interferenciáknak köszönhetően az egyes anyagokra jellemző diffrakciós mintázatot széles szögtartományban rögzíthetjük. A reflexiók alapján a minta kristályos összetevőit és azok arányát azonosíthatjuk. Méréseinket egy Rigaku Miniflex II készülékkel, $\mathrm{Cu} \mathrm{K \alpha}$ $(\lambda=0,15418 \mathrm{~nm})$ sugárzással végeztük a $2 \theta=4-80^{\circ}$-os tartományban.

\subsubsection{Fajlagos felület és pórusméret-eloszlás meghatározása}

A pórusos anyagok fajlagos felületét és pórusméret-eloszlását nitrogén adszorpciósdeszorpciós izotermákból határozhatjuk meg. A minta felületét először vákuumos hőkezeléssel megtisztítjuk, ezzel felszabadítva az adszorpciós kötőhelyeket. Ezután a vizsgált anyagra részletekben szorpcióra képes inert gázt (pl.: nitrogén vagy argon) engedünk, és 
megvárjuk a szorpciós egyensúly beálltát. A nyomáscsökkenésből kiszámíthatjuk az adott egyensúlyi nyomáson megkötődött gáz mennyiségét. Az adszorpciós lépéseket egy előre meghatározott nyomás eléréséig ismételjük. Az izotermákból az adott egyensúlyi nyomáson megkötött összes gáz mennyisége abszolút módon, míg a szerkezeti paraméterek, mint a fajlagos felület vagy a pórusméret-eloszlás, alkalmas modellek illesztésével számíthatóak. Az előzőt a Brunauer-Emmett-Teller (BET) módszerrel (az izoterma 0,1-0,3 relatív nyomáshoz tartozó értékeiből), míg utóbbit a deszorpciós ágból a Barrett-Joyner-Halenda (BJH) eljárás segítségével határoztuk meg.

A vizsgálatokat egy Quantachrome NOVA 2200 típusú automata szorptométerrel -196 ${ }^{\circ} \mathrm{C}$-on végeztük nitrogénnel. A mintákat mérés előtt a szén nanocsövek esetében $200{ }^{\circ} \mathrm{C}$-on, míg a titanát szerkezeteket $150{ }^{\circ} \mathrm{C}$-on vákuumban 60 percig előkezeltük.

\subsubsection{Termogravimetria (TG)}

A TG mérések során ismert tömegü mintát szabályozott gázáramban egy elöre meghatározott hőmérsékletprogram szerint hevítünk fel, miközben folyamatosan mérjük a tömegváltozást. Ezzel a módszerrel a kapott termogravimetriás profil felhasználásával a minta vízvesztési és bomlási lépcsőinek, vagy oxigén gáz esetén az oxidációjának hőmérsékletét határozhatjuk meg. A TG mérések gyakori kiegészítője a differenciális termikus analízis (DTA) technika. Ennek során a mintával együtt egy inert referencia anyagot $\left(\mathrm{pl} . \mathrm{Al}_{2} \mathrm{O}_{3}\right)$ is melegítünk, és mindkét anyag hőmérsékletét folyamatosan mérjük. A legkisebb különbség a minta és a referencia hömérséklete között arra utal, hogy a mintában fázisátalakulás (pl. olvadás, átkristályosodás) vagy kémiai reakció megy végbe. Ezeket a méréseket egy Setaram Instrumentation Labsys müszerrel, $25^{\circ} \mathrm{C}$ kezdőhőmérséklettől $1000{ }^{\circ} \mathrm{C}$-ig, $5{ }^{\circ} \mathrm{C} /$ perc felfütési sebességgel végeztük el.

\subsubsection{Fourier-transzfromációs infravörös spektroszkópia (FT-IR)}

Az IR spektroszkópia az anyag IR aktív rezgési átmeneteinek vizsgálatára szolgáló módszer. A mintát széles, folytonos spektrumú infravörös fénnyel megvilágítva felvehetjük az átengedett (transzmittált) vagy visszavert (reflektált) fény spektrumát. Az elnyelés miatt a detektált spektrumból mindkét esetben azok a hullámhosszak hiányoznak majd, melyek energiái IR aktív rezgéseket gerjesztettek. Az FT-IR vizsgálatokat KBr pasztillás technikával vettük fel, KBr háttérkorrekció mellett. A méréseket egy Bruker Vertex 70 típusú készüléken, 
transzmissziós módot alkalmazva, szobahőmérsékleten végeztük el, 4000-600 $\mathrm{cm}^{-1}$ hullámszám tartományban, $4 \mathrm{~cm}^{-1}$ felbontás és $16 \mathrm{~s}^{-1}$ pásztázási sebesség mellett.

\subsubsection{Raman spektroszkópia}

A Raman spektroszkópia az anyag Raman-aktív rezgési átmeneteinek vizsgálatára szolgáló módszer. A vizsgált anyagot monokromatikus fénnyel (adott hullámhosszú lézer) megvilágítjuk. A visszavert fényt megszürjük a Rayleigh-szórásból eredő fotonoktól, mivel ezek hullámhossza megegyezik a beeső fény hullámhosszával. A spektrumban megjelenő, a Rayleigh frekvenciától kisebb energiájú sávokat Stokes sávoknak, a nagyobbakat anti-Stokes sávoknak nevezzük. A megjelenített Raman spektrum abszcisszáján a gerjesztő fény frekvenciájától mért különbséget tüntetjük fel, amit Raman-eltolódásnak nevezünk. Az ordináta tengely mentén a Stokes (vagy anti-Stokes) sávok intenzitását ábrázoljuk. A Raman spektrumokat egy Thermo Scientific DXR Raman mikroszkóppal vettük fel szobahőmérsékleten, $532 \mathrm{~nm}$ hullámhosszúságú $5 \mathrm{~mW}$ teljesítményü gerjesztő lézerrel. A háttérkorrigált méréseket 3 percig $4 \mathrm{~cm}^{-1}$ felbontás mellett végeztük. 


\section{Eredmények és értékelésük}

\subsection{Szén nanocsövek örlési vizsgálatai}

\subsubsection{A Burgio-Rojac modell kísérleti vizsgálata}

Az őrlés paramétereinek változtatásával képesek vagyunk szabályozni az őrleménynek átadott energiát. A Burgio-Rojac modellel számolható energiaértékeket összevetve az őrlés során tapasztalt darabolódással vagy egyéb tulajdonságbeli változással alátámaszthatjuk a modell használhatóságát szubmikrométeres részecskékre. Ehhez olyan modellanyagot kell választanunk, amelynek jól ismert tulajdonságai vannak és az őrlés során bekövetkező állapotváltozásai is követhetőek. Az izotróp és a 2D-s anyagok nem alkalmasak őrlési modellrendszereknek, mivel már egyszeri beütés hatására is sok kisebb darabra törnek. Az 1D-s szálas vagy csöves anyagok aprózódása azonban jól modellezhető, ezért a további vizsgálatokhoz az Alkalmazott és Környezeti Kémiai tanszéken régóta kutatott többfalú szén nanocsöveket választottuk.

Megközelítésünk alapja az volt, hogy az MWCNT-k tulajdonságaiban kísérletileg megfigyelt változások tendenciáját összevessük a Burgio-Rojac modell segítségével készített őrlési energiatérkép alapján várható eredményekkel. Ehhez szükség volt arra, hogy a Burgio-Rojac modell nélkül is képesek legyünk a változások leírására, így az MWCNT hossza mellett azok Raman $\mathrm{I}_{\mathrm{D}} / \mathrm{I}_{\mathrm{G}}$ arányában és felületi tulajdonságaiban bekövetkező változásokat is mértük.

Kiindulásként tegyük fel, hogy $N_{0}$ darab egyforma hosszúságú MWCNT hosszainak összege $L_{0}$. A továbbiakban tegyük fel: 1) az örlés során a csövek összhossza nem változik; 2) egy ütés egy csövet pontosan két darabra tör; 3) egy MWCNT-t teljes hosszában ugyanakkora eséllyel érhet ütés; 4) törés csak a golyók ütésére következik be. Mindemellett egy $\varepsilon$ faktorral vegyük figyelembe, hogy nem minden ütés okozza az MWCNT törését, mivel egy kritikus beütési energia alatt $\left(E_{k u ̈ s z o ̈ b}\right)$ nincsen elég energia a szén-szén kötések hasítására, ugyanakkor egy küszöbérték feletti ütés több nanocső törését is okozhatja egyszerre egy $A_{\text {beütés }}$ területen. Így , , $i$ ütés után az átlagos csőhossz „, $L$ ” és ,,$\varepsilon ”$ értékei:

$$
\begin{gathered}
\bar{L}=\frac{L_{0}}{N_{0}+i} \\
\varepsilon=\left\{\begin{array}{c}
0, h a E_{b}<E_{\text {küszöb }} \\
k \cdot A_{\text {beütés }}
\end{array}\right.
\end{gathered}
$$


Ha a korábban bevezetett állandó nanocsőhossz-összeg változatlansága helyett azt feltételezzük, hogy a beütések egy része az MWCNT-k amorfizációját okozza, akkor be kell vezetnünk egy „C’ faktort, ami a beütések számától és az ütközések felületétől is függ:

$$
\frac{d C}{d i} \sim-C \cdot A_{\text {beütés }}
$$

Az $\varepsilon$ faktor alapján így:

$$
\frac{d C}{d i}=-C \cdot \varepsilon
$$

A (22) egyenletet $C=1$ és $i=1$ kezdeti feltételekkel megoldva:

$$
\begin{gathered}
C_{i}=e^{-\varepsilon i} \\
\bar{L}=C_{i} \frac{L_{0}}{N_{0}+\varepsilon i}
\end{gathered}
$$

Az MWCNT Raman spektrumainak rögzítése során a karakterisztikus $D\left(1350 \mathrm{~cm}^{-1}\right)$ illetve $G\left(1590 \mathrm{~cm}^{-1}\right)$ sávok intenzitásának aránya alapján jellemeztük a csövek roncsolódását $\left(I_{D} / I_{G}\right)$. Ezzel az irodalom által is használt minőségi információkat kaptunk a megőrölt nanocsövekről. ${ }^{208,}{ }^{209}$ Egy „teljesen ép” MWCNT-ben csak sp² hibridállapotú, hexagonális szerkezetet kialakító szénatomok síkrezgését mérhetnénk, ami a spektrumban a G-sávot eredményezi $\left(I_{G}\right)$. A csövek roncsolódása defektusokat hoz létre a szerkezetben, melynek köszönhetően a szénrács $\mathrm{sp}^{3}$ hibahelyein fononszóródás következik be, és ez jelenik meg a spektrum D-csúcsaként $\left(I_{D}\right)$. A két rezgés relatív intenzitása függ a szénforma szerkezetétől, így amennyiben őrlés következtében a szén nanocsöveken hibahelyek halmozódnak fel, az $\mathrm{I}_{\mathrm{D}} / \mathrm{I}_{\mathrm{G}}$ arány megnő. Korábban végzett tanulmányaink alapján feltételeztük, hogy a Raman spektrumból számított $I_{D} / I_{G}$ hibahely tényező változása leírható a „CC faktorral. ${ }^{210}$ Mivel „C” az amorfizálódott MWCNT-k számától függ, és a Raman mérések során a jelet adó szénféleségek együttesen határozzák meg a hibahely tényezőt, feltételezhetjük, hogy:

$$
\left(\frac{I_{D}}{I_{G}}\right)_{I}=\left(\frac{I_{D}}{I_{G}}\right)_{\infty}-R C_{i}^{3}
$$

ahol $\left(I_{D} / I_{G}\right)_{\infty}$ a végtelen hosszú őrlési idő után felvett hibahely tényező elméleti maximuma, „R” pedig egy normáló tényező. Egy golyó beütési területét Lu és munkatársai munkája alapján határoztuk meg. ${ }^{211} 6 \mathrm{~cm}$ átmérőjü rozsdamentes acéldob és $10 \mathrm{~mm}$ átmérőjü acélgolyók esetén 5-100 mJ/beütés közötti $E_{b}$ mellett $A_{\text {beütés }}=3 \cdot 10^{-1}-10 \cdot 10^{-7} \mathrm{~m}^{2}$ közötti 
értékeket vett fel. A 40 és $100 \mathrm{~mJ} /$ beütési energiákhoz tartozó MWCNT hossz csökkenést és a hibahely tényező növekedését az ,i” beütésszám függvényében az 5.1. ábrán mutatom be, amennyiben $N_{0}=1, L_{0}=1, R=1,\left(I_{D} / I_{G}\right)_{\infty}=1$.

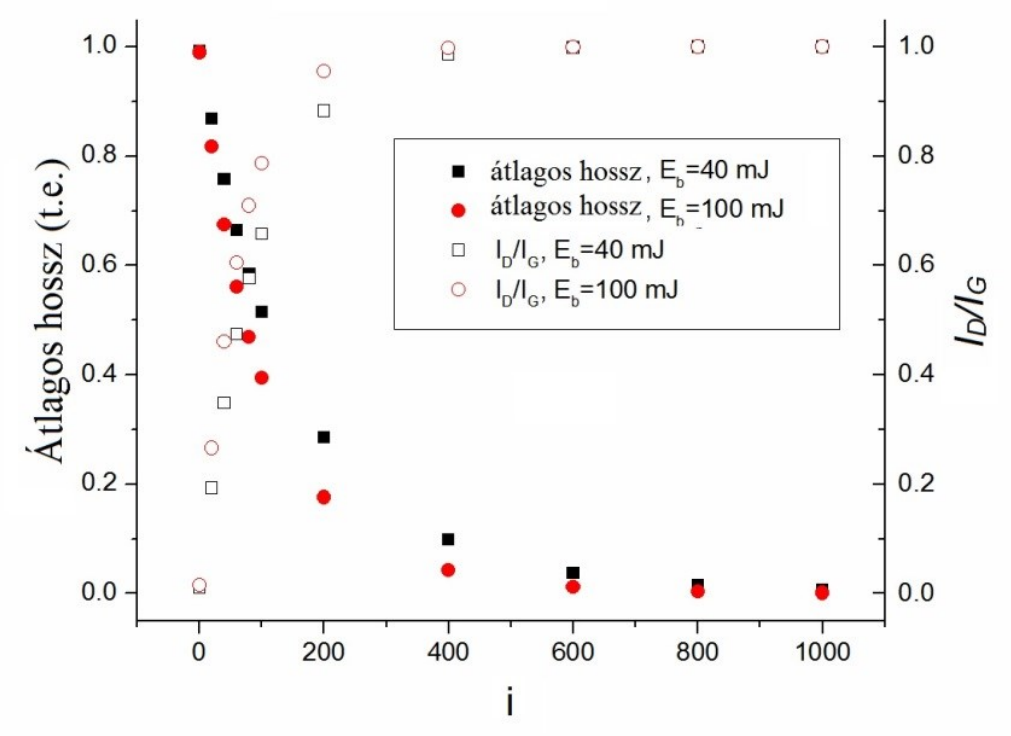

5.1. ábra: Az átlagos nanocsőhossz (• és $\square$ ) és a Raman $I_{D} / I_{G}$ hibahely tényező ( $\square$ és $\circ$ ) várható alakulása az , $i$ ” ütközésszám függvényében $40 \mathrm{~mJ} /$ beütés (fekete négyzet) és $100 \mathrm{~mJ} /$ beütés (piros kör) egyedi ütközési energiánál.

Az 5.1. ábra alapján az alábbi következtetéseket vonhatjuk le: 1) létezik olyan $E_{k u ̈ s z o ̈ b}$ érték, ami alatt a darabolódás nem vagy csak alig történik. 2) az MWCNT-k hosszának csökkenése az ütközések számával exponenciálisan emelkedik, amennyiben $E_{b} \geq E_{k u ̈ s z o ̈ b}$. 3) a Raman $I_{D} / I_{G}$ tényező, azaz a hibahelyek száma gyorsabban nő, mint ahogyan a nanocsőhossz csökken.

Mivel azt akartuk, hogy vizsgálataink eredményei a legszélesebb körben alkalmazhatók legyenek, egy átlagos laboratóriumi malom kelléktárát figyelembe véve a következő paramétereket változtattuk: 1) malom fordulatszáma; 2) őrlés ideje; 3) golyók száma, mérete és ezek eltérő arányai. Így egy $40 \mathrm{db}$ őrlésből álló kísérletsorozatot terveztünk meg, melynek adatait az 5.1. táblázat tartalmazza. A megörölt MWCNT mintákon ezután TEM és Raman spektroszkópiás méréseket végeztünk, valamint $\mathrm{N}_{2}$ adszorpciós vizsgálattal meghatároztuk fajlagos felületüket és porozitásukat. A TEM-mel az egyes mintákról ugyanolyan nagyítás mellett több felvételt is készítettünk (5.2. ábra), majd az „ImageJ” program segítségével mértük meg a csövek hosszát. 


\begin{tabular}{|c|c|c|c|c|c|}
\hline & $\mathbf{A}\left(\Delta \omega_{\mathbf{d}}\right)$ & $\mathbf{B}_{1,2}(\Delta \mathbf{t})$ & $\mathbf{C}\left(\Delta \mathbf{N}_{\mathbf{b}}\right)$ & $\mathbf{D}\left(\Delta \mathbf{N}_{\mathbf{b}}\right)$ & $\mathbf{E}\left(\Delta \mathbf{N}_{\mathbf{b}} \boldsymbol{\&} \Delta \mathbf{d}_{\mathbf{b}}\right)$ \\
\hline$\omega_{\mathbf{d}}(\mathbf{r p m})$ & $\begin{array}{c}150-600 \\
(=50 \mathrm{rpm})\end{array}$ & \multicolumn{4}{|c|}{350} \\
\hline $\mathbf{t}(\mathbf{p e r c})$ & 60 & $\begin{array}{c}1: 5-60 \\
2: 5-320\end{array}$ & \multicolumn{3}{|c|}{60} \\
\hline $\mathbf{d}_{\mathbf{b}}(\mathbf{m m})$ & \multicolumn{2}{|c|}{10} & 5 & 10 & $5 \& 10$ \\
\hline $\mathbf{N}_{\mathbf{b}}(\mathbf{d b})$ & \multicolumn{2}{|c|}{15} & $\begin{array}{c}40-200 \\
(\Delta=40 \mathrm{db})\end{array}$ & $\begin{array}{c}5-25 \\
(\Delta=5 \mathrm{db})\end{array}$ & $*$ \\
\cline { 1 - 5 } & & &
\end{tabular}

\begin{tabular}{|c|c|c|c|c|c|c|c|c|c|}
\hline inta szám & 1 & 2 & 3 & 4 & 5 & 6 & 7 & 8 & 9 \\
\hline ók tömega & $1: 0$ & $10: 1$ & $4: 1$ & $2: 1$ & $1: 1$ & $1: 2$ & $1: 4$ & $1: 10$ & $0: 1$ \\
\hline$--5 \mathrm{~mm}(\mathrm{db})$ & 0 & 8 & 24 & 40 & 60 & 80 & 96 & 112 & 120 \\
\hline$-10 \mathrm{~mm}(\mathrm{db})$ & 15 & 14 & 12 & 10 & 8 & 5 & 3 & 1 & 0 \\
\hline
\end{tabular}

5.1. táblázat: az MWCNT minták őrlési paraméterei.

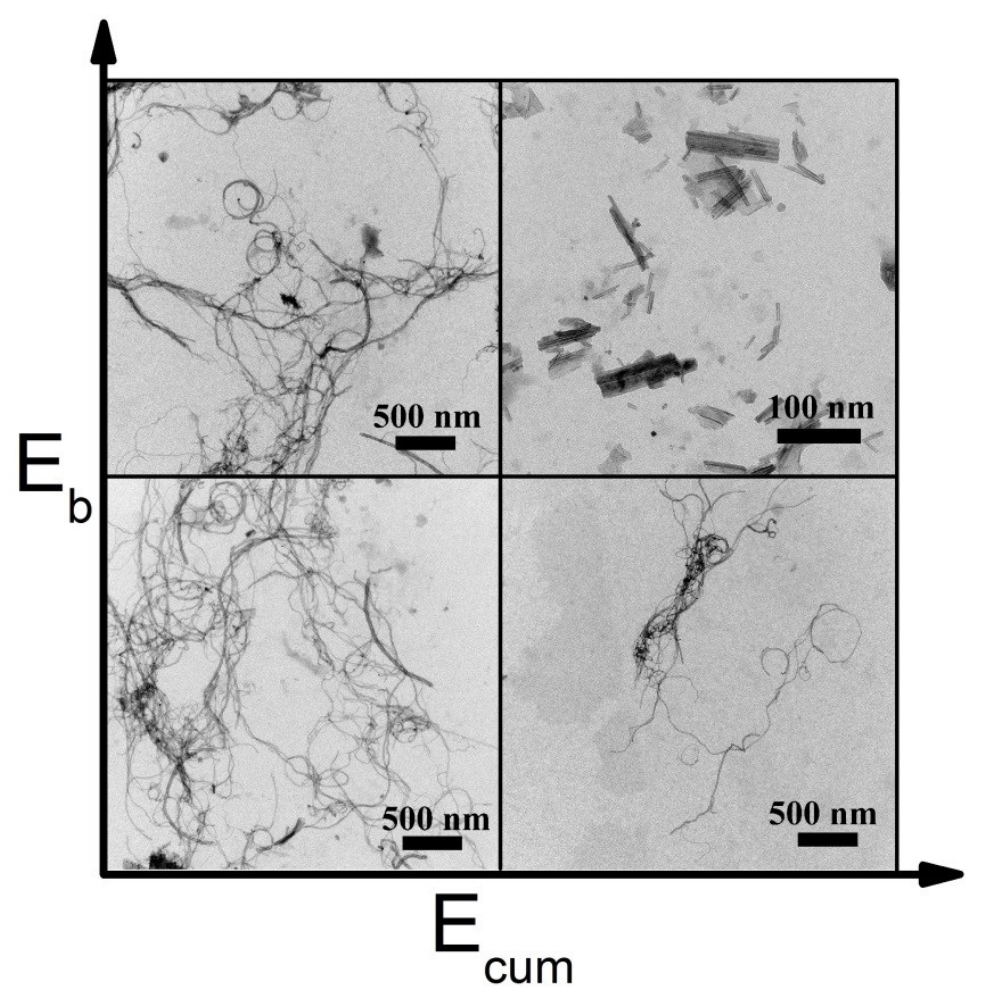

5.2. ábra: relatív alacsony, illetve magas $E_{b}$ és $E_{c u m}$ mellett őrölt MWCNT minták TEM felvételei. 
$\mathrm{Az}$ 5.3. ábrán az „A” és „,B” őrlési sorozatok változóinak (fordulatszám és őrlés ideje) függvényében a nanocsőhossz $(L)$ és a Raman $I_{D} / I_{G}$ értékeit tüntettük fel. Jól látható, hogy a korábban tapasztalt tendencia most is kirajzolódik, azaz az átlagos csőhossz csökken, míg a hibahelyek száma nő mindkét esetben. Kirajzolódik a statisztikai modell korlátai is, hiszen az egymáshoz hasonló őrlések nem válnak el egymástól. Ez a jelenség figyelhető meg az 5.3. ábrán a 350 rpm fordulatszám és a 60 perc őrlési időnél csoportosuló pontok esetén.
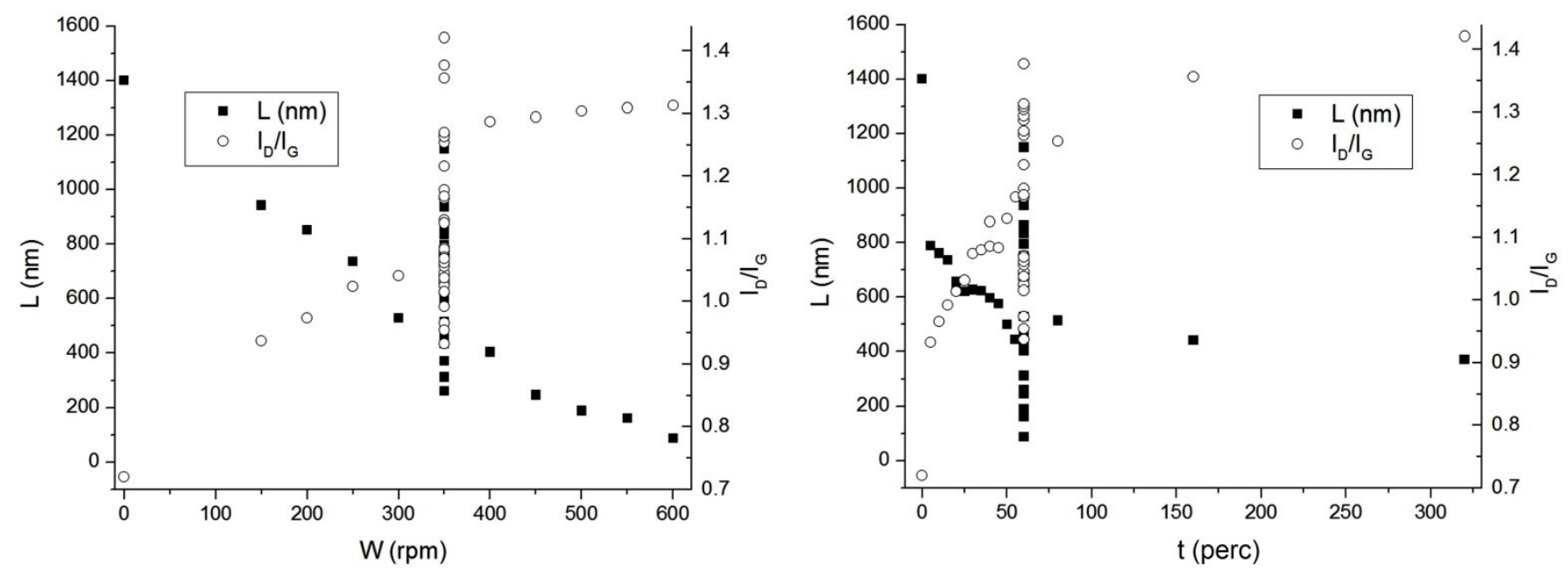

5.3. ábra: Kísérletileg meghatározott átlagos nanocsőhossz $(L)$ és Raman hibahely tényező $\left(I_{D} / I_{G}\right)$ a golyósmalom alaplemez fordulatszáma (balra) és az őrlési idő (jobbra) függvényében.

A következőkben a Burgio-Rojac modell alkalmazásakor már nem a változó paraméter függvényében, hanem a modell által számolt $E_{b}$ beütési energia és az $E_{c u m}$ összes közölt energia függvényében ábrázoltuk az átlagos nanocsőhossz és Raman $I_{D} / I_{G}$ hibahely tényezőben bekövetkezett változásokat. Az 5.4. ábrán térben jelenítettük meg a mérési pontokat, hogy azok jobban áttekinthetőek legyenek. Az ábra baloldali $I_{D} / I_{G}-E_{b}$ vetületéröl leolvashatjuk, hogy $\sim 35 \mathrm{~mJ} /$ beütési energia alatt az MWCNT amorfizálódása nem jelentős $\left(I_{D} / I_{G}=1,0\right)$, míg felette ugrásszerüen megnő az $\mathrm{sp}^{3}$ hibridállapotú szénatomok száma, így $I_{D} / I_{G}=1,3$ értékig emelkedik. A jobboldali $L-E_{b}$ vetület alátámasztja ezt az eredményt. Itt az $L=750 \mathrm{~nm}$ értéknél láthatjuk, hogy a nanocsövek átlagos hosszúsága nem változik lényegesen $E_{b}=35 \mathrm{~mJ} /$ beütés alatt. Efelett az MWCNT-k törése drasztikusan felgyorsul. 

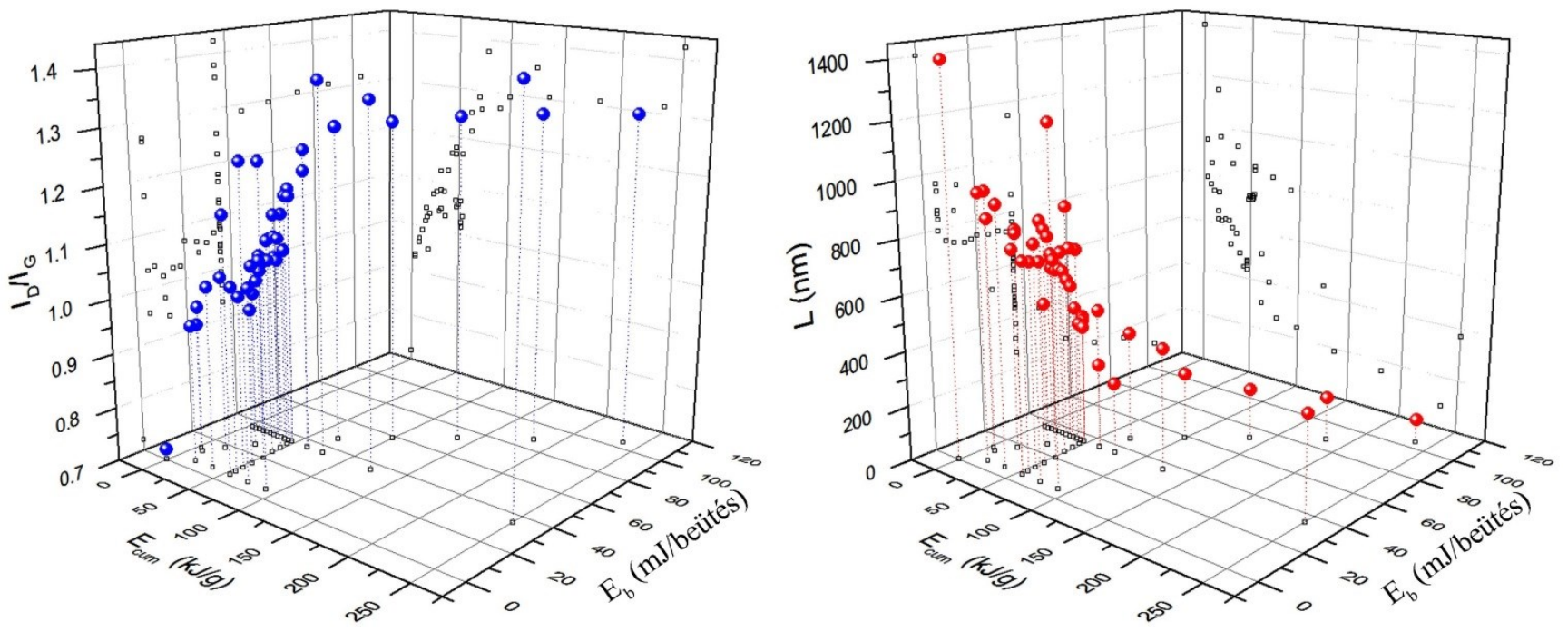

5.4. ábra: Raman spektrumból számított $I_{D} / I_{G}$ hibahely tényező (balra) és átlagos nanocső hossz (jobbra) a Burgio-Rojac modellből számított beütési energia $\left(E_{b}\right)$ és kumulatív őrlési energia $\left(E_{\text {cum }}\right)$ függvényében. A piros és kék gömbök mért pontokat, a ○ szimbólumok azok síkbeli vetületeit jelölik.

A jelenség jó egyezést mutat a statisztikai modellünk első következtetésével. Jelen esetben az $E_{\text {kïszöb }}=35 \mathrm{~mJ} /$ beütés értéknek adódott. Az $I_{D} / I_{G}-E_{c u m}$ függvény növekedése és az $L-E_{\text {cum }}$ vetület csökkenése jól egyezik statisztikai modellünk második állításával, miszerint megfelelő számú ütközéssel a nanocsőhossz csökkenésének trendje exponenciális jellegü. A két vetületet összehasonlítva továbbá megállapítható, hogy a Raman $I_{D} / I_{G}$ tényező $E_{\text {cum }}=75 \mathrm{~kJ} / \mathrm{g}$ értéknél, míg a nanocsövek hossza $E_{\text {cum }}=100 \mathrm{~kJ} / \mathrm{g}$ után kezd stabilizálódni, ami statisztikai modellünk harmadik következtetésének felel meg.

Összességében kijelenthetjük, hogy az MWCNT-k tőrésére felállított statisztikai modellünk helyesnek bizonyult, és állításainkat kísérletileg is igazoltuk a Burgio-Rojac őrlési energia modell segítségével. Így az irodalomban elsőként igazoltuk a modell alkalmazhatóságát szubmikrométeres részecskék bolygó golyósmalmos kezelésére. Ezután már elvégezhettük az egyes malomparaméterek hatásának vizsgálatát az MWCNT darabolódásra, melyet a következő alfejezetekben részletezünk.

\subsubsection{Az alaplemez fordulatszámának hatása (A-sorozat)}

Az alaplemez forgási sebességét 150-600 rpm fordulatszámig változtattuk $50 \mathrm{rpm}$ lépésközzel. Az egy golyó által becsapódáskor kifejtett energia $E_{b}=13,05-208,75 \mathrm{~mJ} /$ beütés, míg az $E_{c u m}=3,69-236,72 \mathrm{~kJ} / \mathrm{g}$ között változott. Az eredményeket az 5.5. ábrán mutatom be. 
A fordulatszám és átlagos MWCNT hossz közti összefüggés egyértelműen kirajzolódik. A nanocsövek átlagos kezdeti hossza $(\sim 1400 \mathrm{~nm})$ már alacsony, $150 \mathrm{rpm}$ fordulatszámon $1 \mu \mathrm{m}$ alá esik, majd a forgás sebességének növekedésével közel azonos tendenciával tovább csökken. Néhány minta méreteloszlás hisztogramját megvizsgálva (5.5. ábra) jól követhető a nanocsövek rövidülése és az egyes tartományok változása.
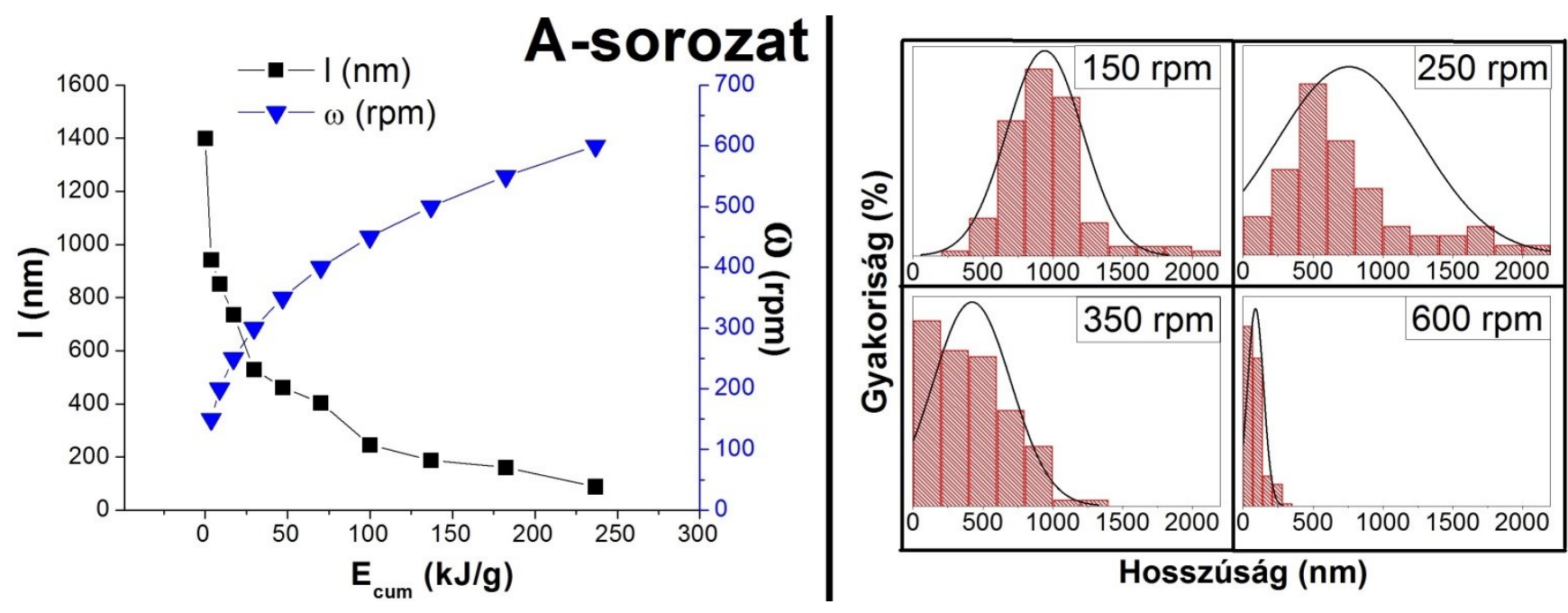

5.5. ábra: Balra: $\boldsymbol{a}$ az MWCNT-k hossza $(l)$ és $\boldsymbol{\nabla}$ az alaplemez fordulatszáma $(\omega)$ az $E_{\text {cum }}$ függvényében. Jobbra: a 150, 250, 350 és 600 rpm fordulatszámon őrölt MWCNT-k hosszainak méreteloszlás hisztogramjai.

Míg a $250 \mathrm{rpm}$ fordulatszámon megőrölt csövek hossza széles skálán mozog, addig 350 rpm értéken többségük már $1 \mu$ m-nél rövidebb. Magasabb fordulatszámú örléskor a jellemző csőhossz $400 \mathrm{~nm}$ alá esik. Amellett tehát, hogy az átlagos csőhossz csökken, eloszlásának szélessége először növekszik, majd csökken. A jelenség azzal magyarázható, hogy egy ütés hatására bekövetkező törés a csövek teljes hosszában ugyanakkora eséllyel történhet meg, ahogyan azt már statisztikai modellünknél is feltételeztük. Az egyre növekvő fordulatszámmal nem csak a beütés energiája, hanem annak frekvenciája is fokozottan nő. Így az eleinte eltérö hosszúságú csövek egyre inkább hasonló méretüre rövidülnek. Kérdéses azonban, hogy az alacsonyabb beütési energia esetén az őrlés idejét meghosszabbítva (tehát a nem elegendő beütési frekvenciát „őrlési idővel pótolva”) is ezt a szükülő hosszeloszlási tendenciát kapnánk-e. Ennek megválaszolására a következő vizsgált paraméternek az őrlés idejét választottuk. 


\subsubsection{Az örlés idejének hatása ( $B_{1,2}$ sorozatok)}

Ahhoz, hogy az $E_{b}$ és $E_{c u m}$-nak a nanocsövek rövidülésében betöltött szerepét pontosabban meghatározzuk, rögzítettük az $E_{b}(71,03 \mathrm{~mJ} /$ beütés) és egyenletesen emeltük az $E_{\text {cum }}$ értékét. Ehhez 5 - 60 perc között változtattuk az örlési időt 5 perces időközökkel. Az 5.1. táblázatban ezt a kísérletsort jelöli a $\mathrm{B}_{1}$-sorozat. Így az $E_{\text {cum }}$ értékét 3,915-46,98 kJ/g közt változtattuk.
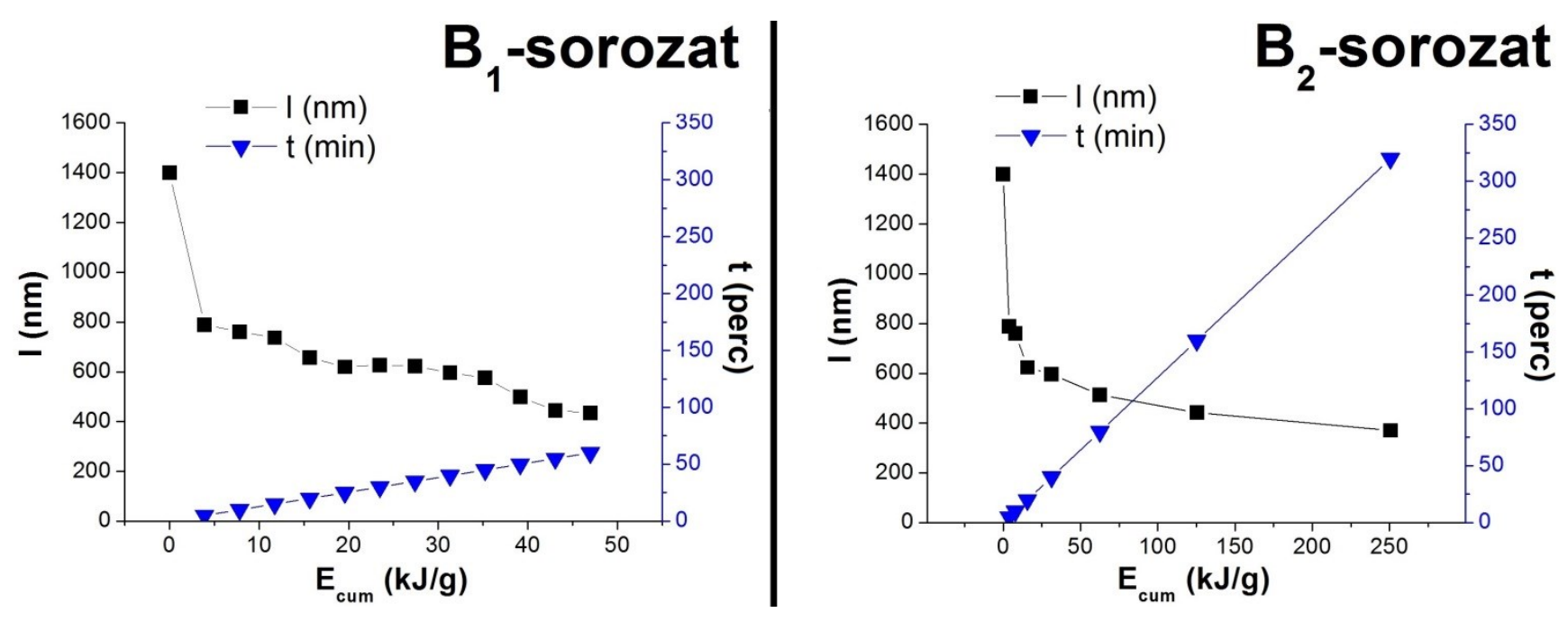

5.6. ábra: $\square$ az MWCNT-k hossza $(l)$ és $\boldsymbol{\nabla}$ az örlés időtartama $(t)$ az $E_{\text {cum }}$ függvényében. Az őrlési idő a $\mathrm{B}_{1}$-sorozat esetén 5-60 percig 5 perces felbontásban, a $\mathrm{B}_{2}$-sorozat esetén 5-320 percig az örlési idők megduplázásával történt.

$\mathrm{Az}$ energiabevitel egyenletes növelésének eredményeként az átlagos csőhossz fokozatosan csökkent. Láthatjuk azonban az 5.6. ábrán, hogy a csövek hosszának csökkenése az őrlési idő emelésével valószínűleg tovább fokozódna, ezért megnöveltük az őrlés idejét 60 percről egészen 320 percre. Az 5.1. táblázatban ez a $\mathrm{B}_{2}$-sorozat, ahol $E_{\text {cum }}$ a $250,72 \mathrm{~J} / \mathrm{g}$-t értéket is eléri. Ha az így kapott „, $\mathrm{B}_{2}$ ” és „A” sorozatokat összevetjük, a következő megállapításra juthatunk: a majdnem teljesen fedésben lévő $E_{c u m}$ tartományt alkalmaztunk mindkét esetben (A: 3,69-236,72 kJ/g; B $: 3,91-250,72$ ), a csövek törése mégis eltérő eredményt mutatott. Míg a fordulatszám emelésével $E_{c u m}=200 \mathrm{~kJ} / \mathrm{g}$ felett $50 \mathrm{~nm}$ alatti partikulumokat kaptunk, addig ugyanezen az $E_{\text {cum }}$ értéken az örlés idejét 300 perc felé emelve sem csökkent az átlagos hossz $400 \mathrm{~nm}$ alá. Tehát a hasonló $E_{c u m}$ tartomány, de rögzített $E_{b}$ jól tükrözi a fordulatszám és őrlési idő kapcsolatát, melyek nem helyettesíthetőek egymással. Az $E_{c u m}$ emelésével megközelíthető, de nem pótolható a megfelelő $E_{b}$ érték, és ez fordítva is igaz, mivel a rövid ideig tartó (tehát kisszámú) nagy energiájú beütések nem feltétlenül eredményeznek megfelelő méreteloszlású terméket. Az átlagos átmérő ugyan elérheti a várt 
értéket, de nem mindegy, hogy mekkora lesz az egyes mérettartományok szélessége. Ennek követésére a „, $\mathrm{B}_{1}$ ” sorozat mintáinak méreteloszlás hisztogramjait az 5.7. ábrán mutatom be. Az 1 óra őrlési idő alatt fokozatosan csökken az átlagos csőhossz, ugyanakkor a minimális és maximális értékek hozzávetőleg $1500 \mathrm{~nm}$ tartományt ölelnek fel. Az „A” sorozat esetén 600 rpm fordulatszámon ugyanennyi idő alatt a csőhossz 360 nm alá esett (5.5. ábra).

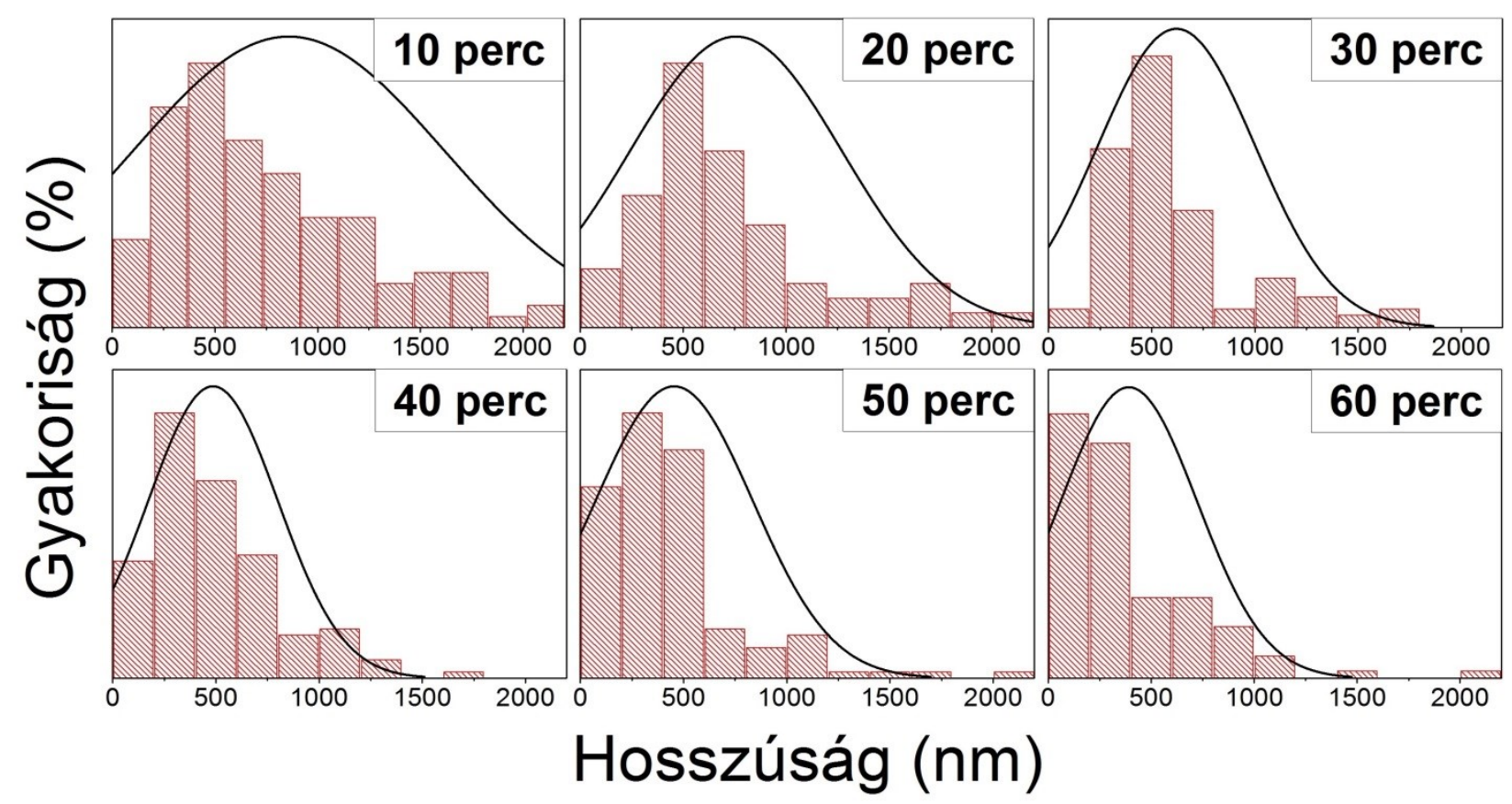

5.7. ábra: a $B_{1}$-sorozat mintáinak méreteloszlás hisztogramjai az MWCNT-k hossza szerint.

Beláthatjuk, hogy amennyiben kis szórással akarunk meghatározott méretű mintát előállítani, úgy az $E_{b}$ és $E_{c u m}$ helyes megválasztása egyaránt fontos. Míg az előző alapvetően meghatározza a legkisebb elérhető méretet, addig a legszükebb mérettartományú terméket az utóbbi optimális beállításával tudjuk előállítani.

\subsubsection{Az örlögolyók számának és méretének hatása (C, D, E sorozatok)}

Ebben az esetben két hasonló $E_{c u m}$ tartományt vizsgáltunk meg két különböző $E_{b}$ érték mellet. Ezt különböző tömegü golyók használatával értük el, ami az $5 \mathrm{~mm}$ átmérőjü golyók esetén 0,48 g, a 10 mm-es golyók esetén 3,92 g volt (az egyes golyók tömege használat közben csökken, így a fenti adatok 30-30 golyó átlagára vonatkozattuk). Az 5 mm átmérőjü golyók (C-sorozat) mindegyike 10,3 mJ/beütési, míg a $10 \mathrm{~mm}$-es golyók (D-sorozat) $71,03 \mathrm{~mJ} /$ beütés energiával rendelkeztek. 
Az 5-5 mérési ponttal rendelkező „C” és „D” sorozatok $E_{\text {cum }}$ tartományai közel átfedésben vannak. Ez az 5 mm-es golyók esetén 18,17 - 90,84 kJ/g, míg a 10 mm-es golyóknál 15,66 - 78,32 kJ/g, ami az előzőeknél egy szükebb skálát jelent. A „C” és „D” sorozatok eredményei azt mutatták meg, hogy azonos össztömegü golyók őrlési hatékonyságában mekkora különbséget okoz az egyedi golyók eltérő tömege (5.8. ábra).
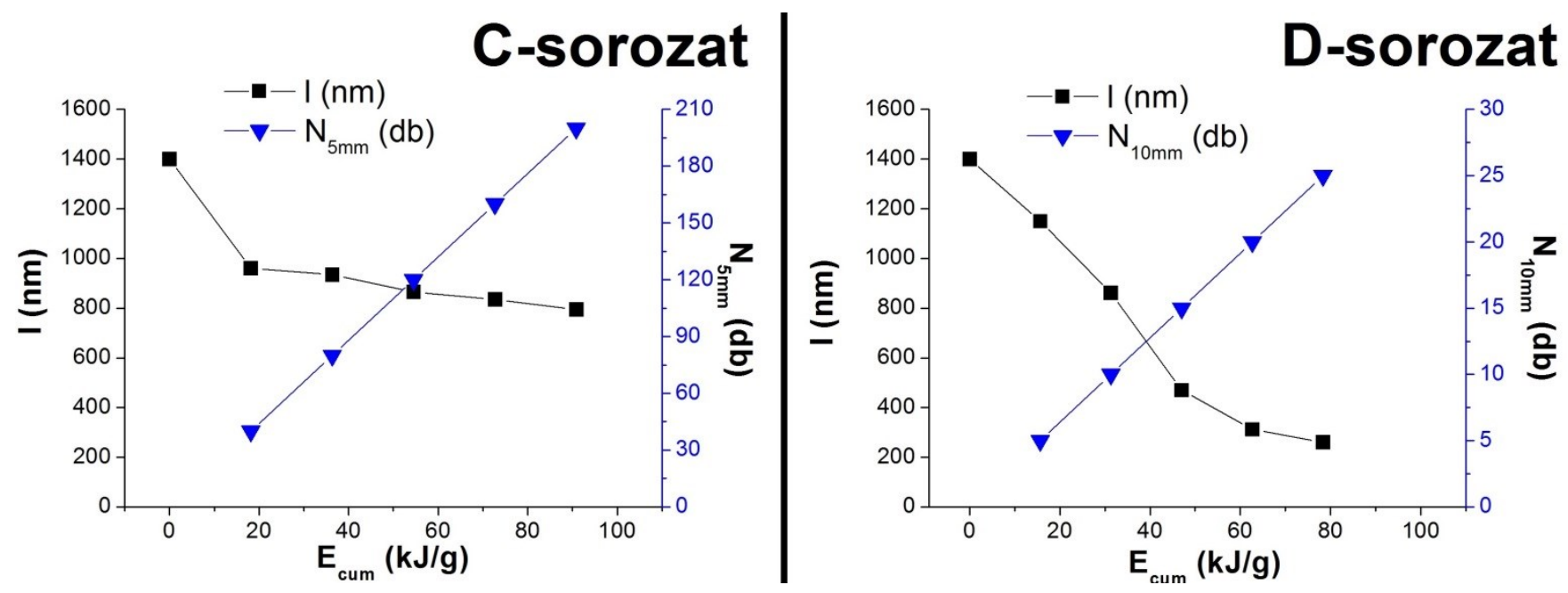

5.8. ábra: $\square$ az MWCNT-k hossza ( $l$ ) és $\boldsymbol{\nabla}$ az $5 \mathrm{~mm}$ (C-sorozat), illetve $10 \mathrm{~mm}$ (D-sorozat) átmérőjü őrlőgolyók száma az $E_{c u m}$ függvényében.

A fenti ábrán láthatjuk, hogy már a legalacsonyabb golyószám használatakor is közel $150 \mathrm{~nm}$ különbség van az $5 \mathrm{~mm}$ és a $10 \mathrm{~mm}$ átmérőjü golyókkal elérhető átlagos nanocsőhosszban. A nanocsövek méretcsökkenési tendenciájának különbsége a két sorozat között ezután még szembetűnőbb. Míg a $10 \mathrm{~mm}$-es golyók $E_{\text {cum }}=80 \mathrm{~kJ} / \mathrm{g}$ érték körül $250 \mathrm{~nm}$ hosszúságú csöveket eredményeztek, addig ugyanekkora energiánál a C-sorozat esetében mindössze

$800 \mathrm{~nm}$ átlagos csőhosszat mértünk. Az eredményeket összehasonlítva a „B” sorozatoknál tett megfigyelésekkel a következőkre jutottunk: az adott $E_{b}$ értékkel elérhető csőhossz csökkenésnek van egy alsó határa, ami az $E_{c u m}$ növelésével nem tolható ki korlátlanul lefelé. Ezt a statisztikai modellünknél már felvetettük az $E_{k u ̈ s z o ̈ b}$ bevezetésével. Az is megfigyelhetö, hogy a kisebb $E_{b}$-vel rendelkező 5 mm-es golyók az első mérési pontban kisebb átlagos csőhosszt produkáltak. Ez azzal magyarázható, hogy a becsapódások frekvenciája esetükben 8-szor nagyobb volt, mint a 10 mm-es örlőgolyóknál.

Az $E_{\text {cum }}$ az egyedi becsapódások összegeként fogható fel. Emiatt vizsgáltuk, hogy az eltérő tömegü golyók együttes használata esetén számolt $E_{c u m}$ is korábbi tapasztalatainkhoz hasonló eredményt hoz-e. Lényegében a „C” és „D” sorozatokat kombinálva az 5 és 
10 mm-es örlőgolyók arányát változtatva 9 mintát készítettünk úgy, hogy össztömegüket közel állandó értéken tartottuk (5.1. táblázat). Az $E_{c u m}$-t az 5 és $10 \mathrm{~mm}$ átmérőjü golyók arányában határoztuk meg, de mivel a golyók össztömege minden esetben $\sim 60$ gramm volt, ez szük határokon belül változott: 47 - 54,5 kJ/g. A kísérlettől azt vártuk, hogy az 1 : 0 aránytól $(10 \mathrm{~mm}: 5 \mathrm{~mm})$ a $0: 1$ golyóarányig haladva az aprítási hatékonyság folyamatosan romlani fog, és átmenetet figyelhetünk meg a két szélsőérték közt, melyek a „C” és „D” sorozatok esetén 850 és 450 nm-nek adódott. Ettől azonban lényeges eltérést tapasztaltunk, amit az 5.9. ábrán mutatok be. Az előzőektől eltérően az $E_{c u m}$ és átlagos nanocsőhossz értékeket az egyes minták azonosítójának függvényében ábrázoltuk. Az 1-es (D-sorozat 3. tagja) és 9-es (C-sorozat 3. tagja) minták esetén a korábban tapasztalt átlagos csőhosszat mértük. A két szélsőérték közti átmenet helyett azonban az 5 és 10 mm-es golyók arányától függetlenül közel ugyanakkora, 750 nm-es átlagos hosszakat mértünk.

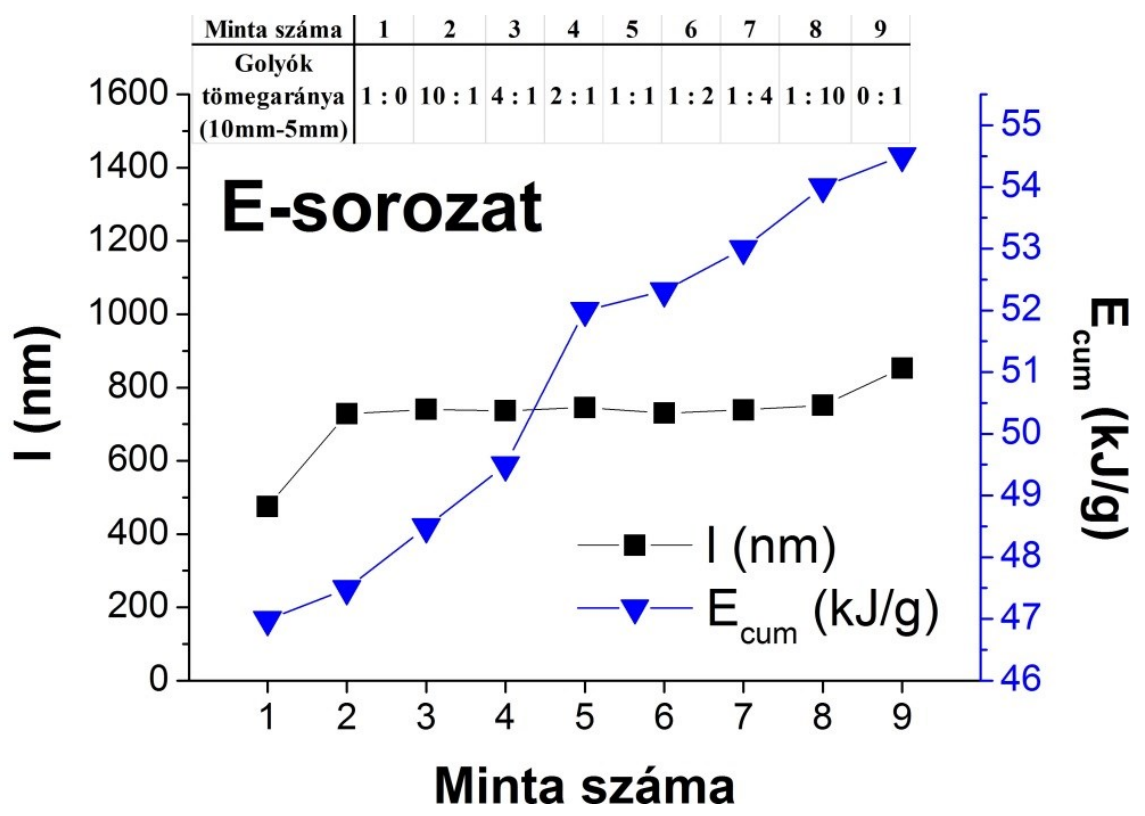

5.9. ábra: - az MWCNT-k hossza ( $l$ ) és $\boldsymbol{\nabla}$ az egyes őrlések $E_{\text {cum }}$ értékei a különböző arányban alkalmazott $10 \mathrm{~mm}$ és $5 \mathrm{~mm}$ átmérőjü golyók függvényében. A grafikon feletti táblázat az őrlőgolyók arányait mutatja.

A „C" és „D” sorozatok esetén eltérő csőhosszakat mértünk a megegyező $E_{\text {cum }}$ tartomány ellenére, mert a különböző átmérőjü golyók az egyidejü használat közben zavarják egymás mozgását. A tipikus ,vízesés” effektus nem képes kialakulni, így egy közel állandó állapotot fenntartva az $E_{b}$ is rögzített érékkel bír a várt 10,3 - 71,03 mJ/beütés közti fokozatos átmenet helyett. Így lényegében a Burgio-Rojac egyenlet alkalmazhatóságát sikerült még inkább alátámasztani, miszerint különböző beállítások esetén, amennyiben az $E_{b}$ és $E_{c u m}$ is 
azonos értéket adnak, az őrlés hatékonysága nem változik. Így akár több eltérő tulajdonságú malom beállításai is összehangolható a fenti adatok ismeretében.

\subsubsection{Az őrlési paraméterek hatásainak vizsgálata Raman spektroszkópiával}

A minták Raman spektrumainak felvétele után a kapott $D$ és $G$ csúcsok intenzitásait számítógépes elemzésnek vetettük alá. $\mathrm{Az} I_{D} / I_{G}$ arányok értékeit az előzőekhez hasonlóan a szén nanocső hossz és $E_{\text {cum }}-\mathrm{k}$ mellett tüntettük fel (5.10. ábra). Önmagukban a Raman mérések eredményei nem lettek volna elégségesek az őrlés követésére, hiszen az összetört MWCNT-k hosszáról nem szolgálnak információval. A TEM alapú elemzést azonban kiválóan kiegészítik. Az eredményeket az 5.10. ábra foglalja össze. A sorozatok elnevezése megegyezik az előző fejezetben alkalmazottakkal. Az $I_{D} / I_{G}$ arányok a vártnak megfelelően az őrlés hatására minden esetben növekedtek.

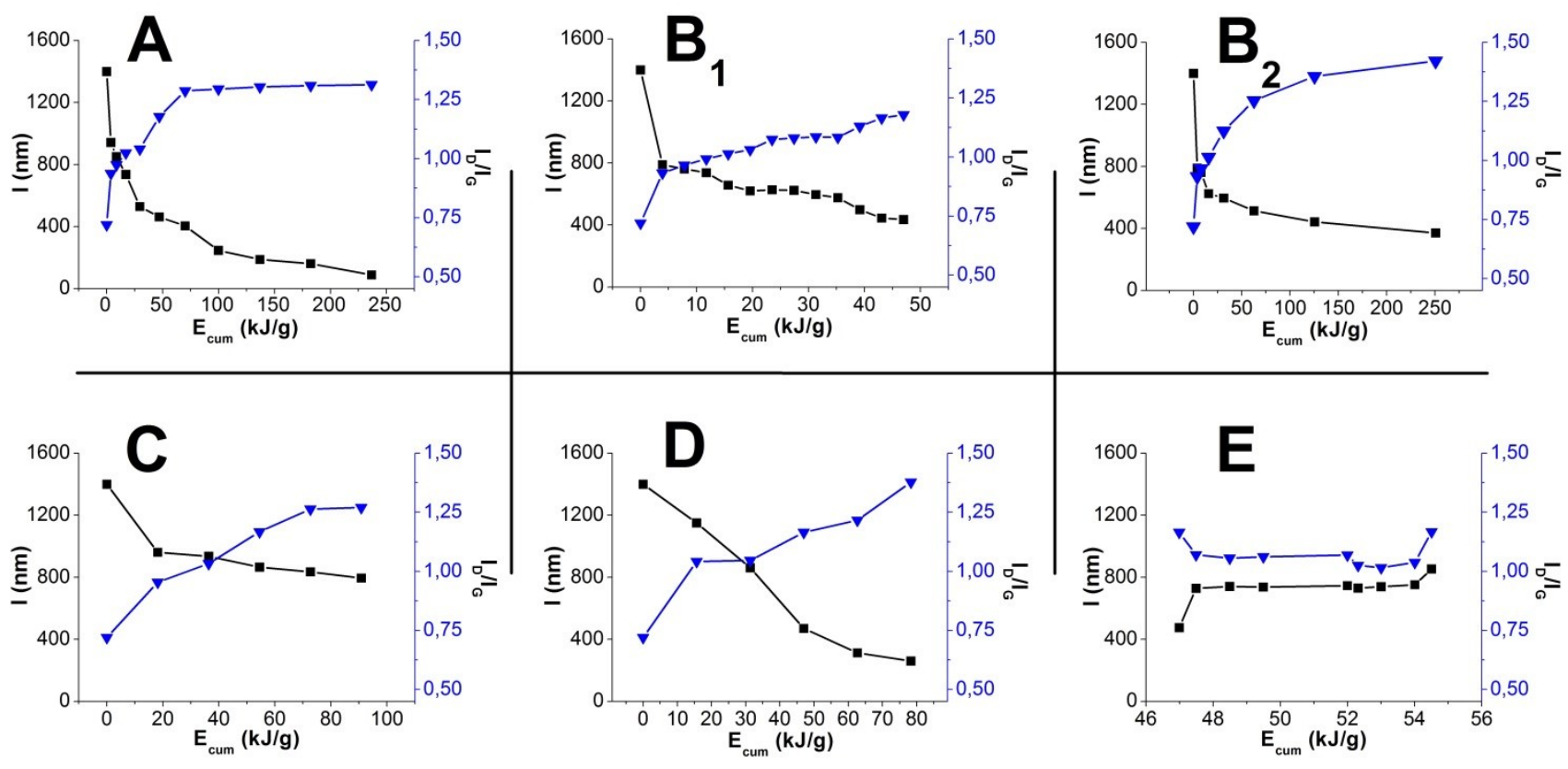

5.10. ábra: az őrlési sorozatok Raman spektroszkópiás vizsgálatának eredményei. - az MWCNT-k hossza $(l), \nabla$ a minták Raman $I_{D} / I_{G}$ tényezője az $E_{c u m}$ függvényében.

A kezeletlen MWCNT $I_{D} / I_{G}=0,75$ körüli értékkel bírnak, ami minden sorozatnál 1,0 felé emelkedik. Az $E_{\text {cum }}$ lefutását összevetve a Raman mérések eredményeivel nagyon hasonló trendeket figyelhetünk meg. Az őrlésből eredő defektusok nem feltétlenül járnak a nanocsövek darabolódásával, így kisebb beütési energia, de hosszan tartó kezelés mellett is indokolt az $I_{D} / I_{G}$ emelkedése. Főleg a „, $\mathrm{B}_{1}$ ” és „, $\mathrm{B}_{2}$ ” sorozatok esetén figyelhető meg, ahogyan az $E_{\text {cum }}$ emelkedését követi az $I_{D} / I_{G}$ tényező növekedése a teljes mérési tartományban. Ezzel szemben az „A” sorozatban már $400 \mathrm{rpm}$ fordulatszám mellett az $I_{D} / I_{G}=1,3$ körüli értéken 
tetőzik. Érdekes még, hogy a „C” és „D” sorozatok $I_{D} / I_{G}$ értékeinek alakulásai közt nem oly számottevő a különbség, mint a nanocsövek hosszának változásában. A csövek szerkezeti roncsolásához a nyolcadakkora $(5 \mathrm{~mm})$ tömeggel rendelkező golyók is elegendőek, míg darabolódásukat nem idézik elő ugyanakkora intenzitással, mint a $10 \mathrm{~mm}$ átmérőjű golyók.

A Raman mérések tovább erősítették az alkalmazott Burgio-Rojac egyenlet helyességét. Plusz információként rávilágítottak arra, hogy míg a csövek hosszeloszlásának szabályozásához mind a kétféle energiaértéket meg kell határozni, addig roncsolt csövek előállításakor a megfelelő idejü kezelés, azaz $E_{\text {cum }}$ szükséges. Ez fontos lehet az MWCNT-k funkcionalizálása vagy kompozit anyagként való alkalmazása esetén, hiszen ilyenkor a csöveken található hibahelyeknek kiemelt szerepük van. ${ }^{212,213}$ A beütési energia jelen esetben föként a defektusok mértékében játszik fontos szerepet, ami egészen a csövek darabolódásáig vezethet. Így a folyamatnak az alacsony $E_{b}$ és magas $E_{c u m}$ kedvez.

\subsubsection{MWCNT felületi tulajdonságainak vizsgálata}

A mérések során kétféle információt kaptunk a mintáinkról: 1) fajlagos felület mérete, ami megadja a nitrogénmolekulák számára elérhető összes felület nagyságát; 2) pórusméret-eloszlás, ami a porozitásról ad információt. Fontos megjegyezni, hogy a nitrogénadszorpciós mérések hossza miatt (ami ötpontos izoterma felvétele esetén is 5-6 óra) azokat nem végeztük el az összes mintára, de a mérési pontokat úgy ritkítottuk, hogy az eddig vizsgált teljes energia tartományt lefedjék. Az így kapott eredményeket az 5.11. ábrán mutatom be.

A korábban a Raman méréseknél bemutatott defektusok számának növekedése az MWCNT-k felületi és porozitási tulajdonságait is alapvetően meghatározza. Jelen esetben az $E_{b}$-nek van meghatározó szerepe abból a szempontból, hogy a feldarabolt csövek törési felülete hozzájárul a fajlagos felület növekedéséhez. A kezeletlen MWCNT felületét $A_{S}=150 \mathrm{~m}^{2} / \mathrm{g}$-nak mértük. Ez megfelel az irodalomban leírt átlagos MWCNT-k fajlagos felületének. ${ }^{214} \mathrm{Az}$ „A” és „, $\mathrm{B}_{2}$ ” sorozatoknál megfigyelhetjük a nanocsövek felületének gyors növekedését közel hasonló tendenciával, amit $E_{\text {cum }}=100 \mathrm{~kJ} / \mathrm{g}$ felett egy csökkenő szakasz követ. 


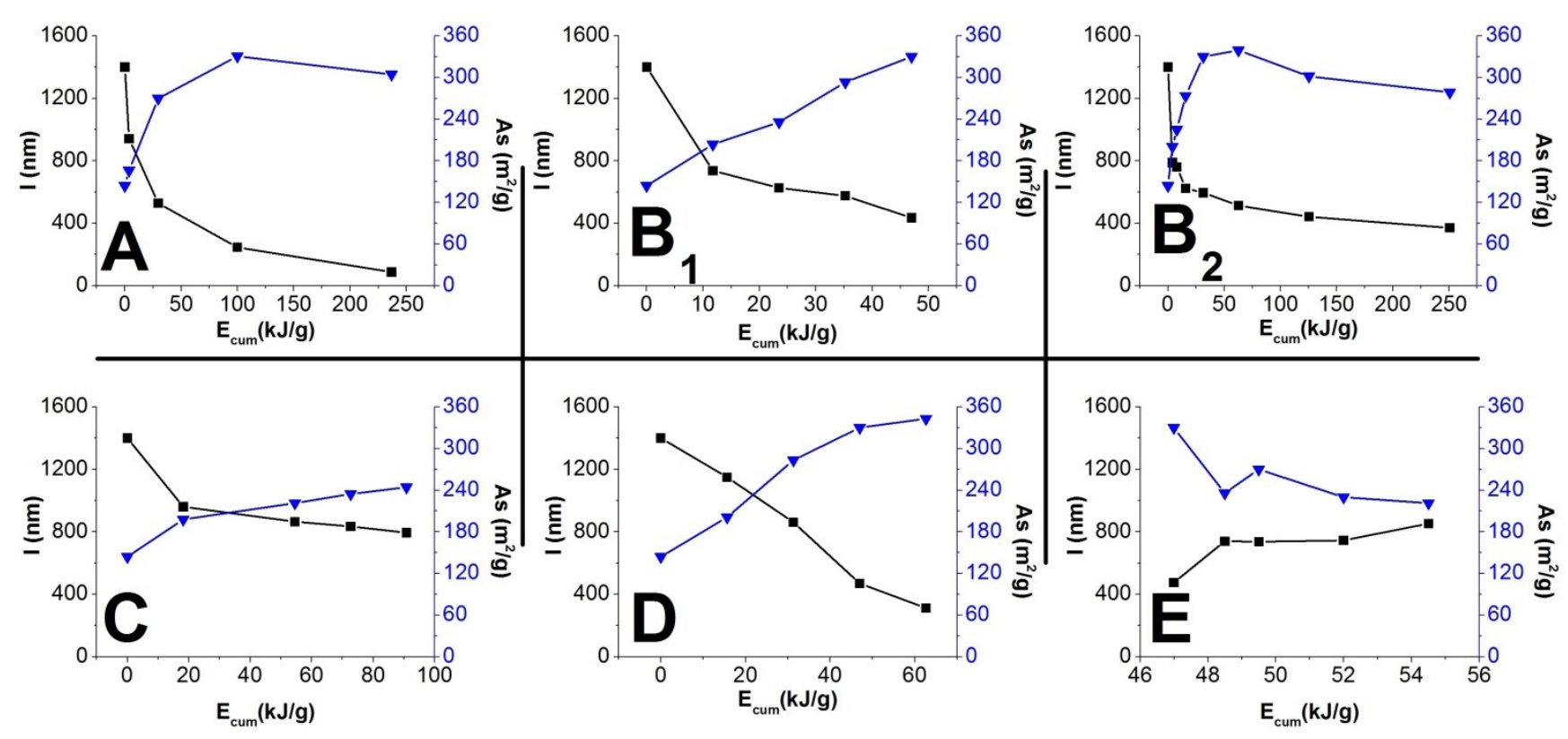

5.11. ábra: az őrlési sorozatok $\mathrm{N}_{2}$ adszorpciós vizsgálatának eredményei. — az MWCNT-k hossza $(l), \boldsymbol{\nabla}$ a minták fajlagos felülete $\left(A_{S}\right)$ az $E_{\text {cum }}$ függvényében.

Eszerint - ahogyan azt a 2.7. fejezetben már tárgyaltuk - a rendszernek átadott energia emelésével az egyedi részecskék aprózódását egy kritikus érték felett már azok növekedése váltja fel, mivel a különálló szemcsék ,összeolvadhatnak”. Ez a fajlagos felület csökkenéséhez, illetve polimorf módosulatok megjelenéséhez vezethet. A későbbiekben majd láthatjuk, hogy malmunkkal képesek vagyunk a $\mathrm{TiO}_{2}$ anatázból rutillá történő átkristályosítására, ami magas, $600{ }^{\circ} \mathrm{C}$ feletti hőmérsékletet igényel. ${ }^{215} \mathrm{~A}$ „C” és „D” sorozatok összehasonlítása során a már korábban levont következtetést tudtuk megerősíteni, miszerint hiába alkalmaztunk hasonló $E_{c u m}$ tartományt, az $E_{b}$ értékek az 5 mm-es golyók esetén nem voltak képesek akkora aprítást végezni, hogy a fajlagos felületet $240 \mathrm{~m}^{2} / \mathrm{g}$ fölé emeljék. Ezzel szemben a „D” sorozat (10 mm-es golyók) ötödik mért pontjában a fajlagos felület a $340 \mathrm{~m}^{2} / \mathrm{g}$-t is elérte.

Az egyik legfontosabb következtetésünk, hogy a túlzott energiabevitel az elvárttal éppen ellentétes hatást fejthet ki. Tehát ha azzal akarunk minél kisebb részecskeméretet elérni, hogy a kis $E_{b}$-t túlzott $E_{c u m}$-mal kompenzáljuk, könnyen kiléphetünk az őrlési paramétertér optimális részéből. A „kevesebb néha több” elve itt is érvényesül.

Felvettük az „A” és „, $\mathrm{B}_{1}$ ” sorozatok 4 mért pontjának teljes izotermáját is. Ezekből a minták pórusméret-eloszlása is meghatározható a Kelvin-egyenlettel a BJH-módszer segítségével (5.12. ábra). ${ }^{216} \mathrm{~A}$ kiindulási mintánk pórusméret-eloszlása megfelel az irodalomban ismert mezopórusos szén nanocső karakterisztikának. ${ }^{217} 150 \mathrm{rpm}$ fordulatszámon 
(A-sorozat) vagy az 5 percig ( $\mathrm{B}_{1}$-sorozat) örölt minták pórusméret-eloszlásából látható, hogy $r=18$ Å-től egy erős emelkedés indul meg. Ez mind az $E_{b}$, mind az $E_{\text {cum }}$ növelésével jelentősen emelkedik, ami azzal magyarázható, hogy az egyre kisebb darabokra tört csövek belső csatornái egyre nagyobb mennyiségben válnak elérhetővé a nitrogénmolekulák számára.
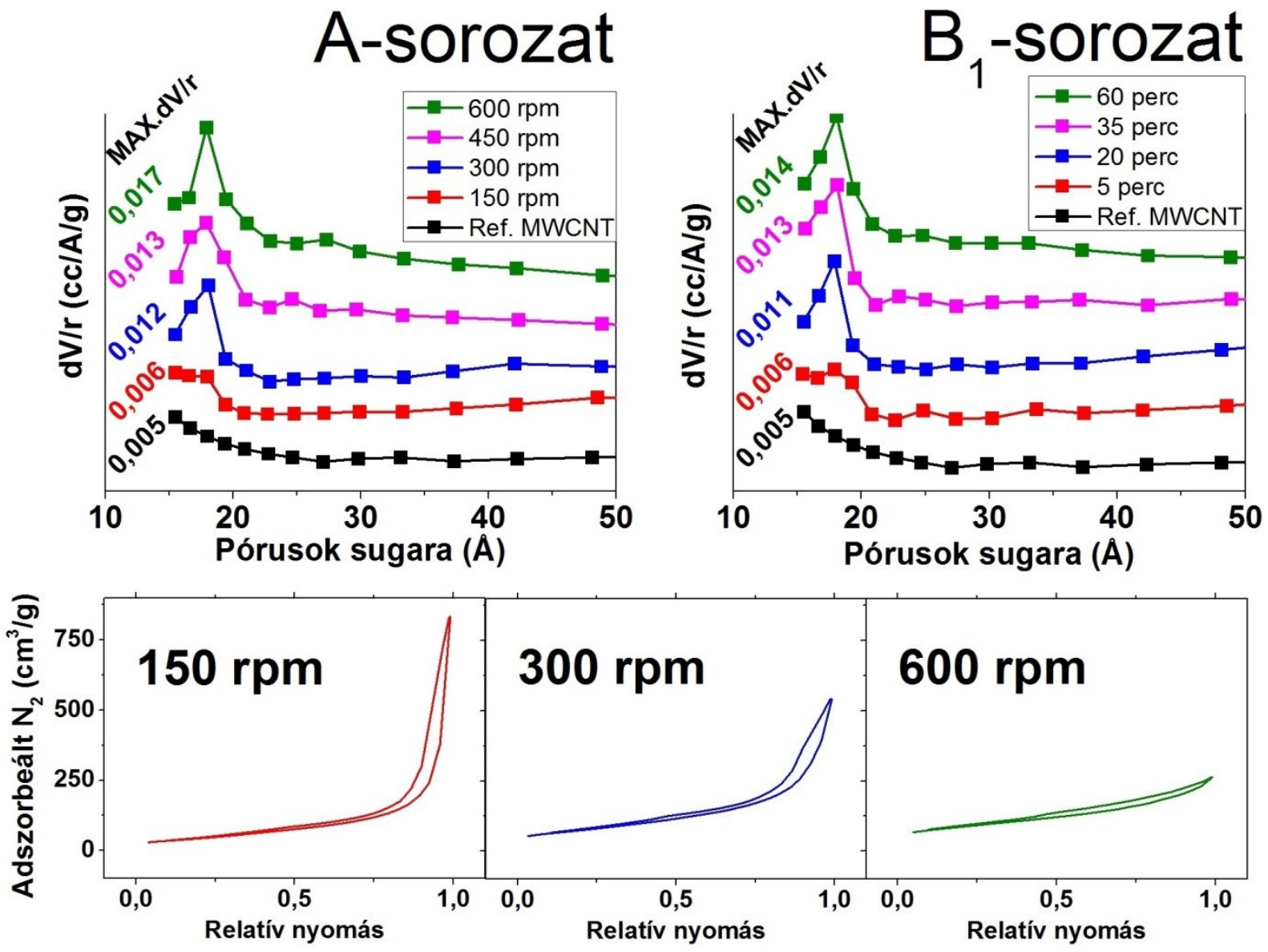

5.12. ábra: (fent) az „A” és „, $\mathrm{B}_{1}$ ” mintasorok 4-4 tagjáról felvett pórusméret-eloszlások, valamint (lent) a 150, 300 illetve 600 rpm fordulatszámon örölt minták teljes nitrogén adszorpciós-deszorpciós izotermái.

Az A-sorozat három tagjáról bemutatott II-es típusú izotermákon (IUPAC szerint) megfigyelhetjük, ahogy a növekvő befektetett őrlési energia hatására a nagyobb relatív nyomásoknál (főleg $p / p_{0}=0,7$ felett) egyre kisebb mennyiségü adszorbeált nitrogént mértünk.

Összegezve az alábbi megfigyeléseket tettük a szén nanocsövek különböző beütési és kumulatív energiával való kezelése során: 1) kimutattuk, hogy a Burgio-Rojac féle egyenletben szereplő kiválasztott paraméterek változtatásával az egy golyó beütési energiája, valamint a teljes őrlés során a rendszernek átadott energia mekkora mértékben változik, és ez mennyire van összhangban a szén nanocsövek hosszának változásával. Ezzel a fenti egyenlettel készített őrlési térképek alkalmazhatóságát erősítettük meg. Ez lehetővé teszi a 
különböző malmok, illetve őrlési beállítások összehangolását, valamint az őrlések előre tervezhetőségét, amivel az optimalizálási folyamatok lényegesen lerövidíthetőek. Ugyanakkor megmutattuk, hogy az egyes paraméterek nem feltétlenül kompenzálhatóak egymással, így például az örlési idő az alkalmazott fordulatszámmal. Az $E_{b}$ és $E_{\text {cum }}$ értékeinek összehangolása tehát kiemelten fontos, amennyiben jól meghatározott morfológiával rendelkező terméket kívánunk előállítani. 2) Az egyes változók korlátozott cseréjéhez leginkább a különböző méretü és számú golyók használata alkalmas. Ezeknél a sorozatoknál (C és D) tapasztaltuk leginkább a pontos szabályozhatóságot az $E_{b}$ esetén, míg az $E_{c u m}$ beállítására az őrlési idő tủnt a legalkalmasabbnak. 3) A Raman mérések által megmutattuk, hogy a szén nanocsövek hossza és a felületi defektusok mennyisége nem minden esetben változik párhuzamosan. Kellően alacsony $E_{b}$ és magas $E_{c u m}$ mellett elérhető, hogy a csövek ne töredezzenek túlzottan, ugyanakkor megnövelhetjük a felületén található hibahelyek számát, ami kibővíti felhasználhatóságukat. 4) A nitrogénadszorpciós mérések eredményeként azt kaptuk, hogy a túlzott energiabefektetés azzal járhat, hogy őrlés közben a részecskék méretének csökkenése megfordul és a kisebb részek szintereződés révén növekedni kezdenek. Ezt különösen akkor kell figyelembe venni, amikor egy előre kalkulált energiájú őrlésnél nem a várt méretcsökkenést tapasztaljuk, és ebből következtetéseket akarunk levonni. 


\subsection{A regisztrált nyomás-idő görbe értelmezése}

A $\mathrm{CO}_{2}$ nyomásának és a konverziónak a kapcsolata kulcsfontosságú a karbonát alapú fém-oxid nanorészecskék mechanokémiai szintézisének optimalizálásában, mivel a bolygó golyósmalomban jellegénél fogva nagyon nehéz más in situ analitikai eljárást használni. Az $\mathrm{SnO}_{2}$ karbonátos reakcióúton történő mechanokémiai előállítására irányuló előkísérleteink során a rögzített nyomás-idő görbe váratlan viselkedésére figyeltünk fel. Mivel a reakció másodrendü kinetikájának megfelelő konverzió-idő függvénye telítési görbe jellegü, így a konverzióval arányosnak feltételezett $\mathrm{CO}_{2}$ parciális nyomásának alakulását is ilyennek vártuk. Ezzel szemben a kísérleti tapasztalat az volt, hogy 1) a nyomásemelkedés nem érte el az elméletileg számolt maximumot még akkor sem, amikor az $\mathrm{SnCl}_{2}$ reakciópartner teljesen elfogyott és 2) telítésbe átmenő folyamatos nyomásemelkedés helyett lépcsőzetes emelkedést tapasztaltunk (5.13. ábra).

A jelenség megértéséhez az $\mathrm{SnCl}_{2}$ és $\mathrm{Na}_{2} \mathrm{CO}_{3}$ 1:1 mólarányú reakciójából származó nyomás-idő görbét újra rögzítettük (5.13. ábra). A bemért mennyiségekből számolható a $\mathrm{CO}_{2}$ várható maximális parciális nyomása. Ezt akkor kapjuk, ha az összes reaktáns átalakult, tehát a $\mathrm{Na}_{2} \mathrm{CO}_{3}$-ból minden $\mathrm{CO}_{2}$ felszabadul és az őrlőedény gázterébe kerül. Így a reakció végén az őrlőedényben $425 \mathrm{kPa}$-t kellett volna mérnünk. Az elméleti 100\%-os konverzióhoz tartozó hőmérsékletet tapasztalati úton határoztuk meg (90 perc után átlagosan $31 \pm 2{ }^{\circ} \mathrm{C}$ ). A konverziós értékek $(K)$ számításához az őrlőedény szabad térfogatát a kiindulási és végtermékek térfogatainak átlagából számítottuk. A kezdeti és végállapot minimális és maximális szárazanyag-térfogatát átlagosan $12,2 \mathrm{~cm}^{3}$-nek vettük $\left(\mathrm{V}_{\min }=11,34 \mathrm{~cm}^{3}\right.$ a reakció végén $1: 2 \mathrm{SnCl}_{2}: \mathrm{Na}_{2} \mathrm{CO}_{3}$ mólarány esetén; $\mathrm{V}_{\max }=13,06 \mathrm{~cm}^{3}$ a reakció elején $1: 1 \mathrm{SnCl}_{2}$ : $\mathrm{Na}_{2} \mathrm{CO}_{3}$ mólarány esetén). Az őrlőedény és őrlőgolyók pontos térfogatát méréssel határoztuk meg, így előbbire 260,03 $\mathrm{cm}^{3}$-t, míg az $50 \mathrm{db}$ őrlőgolyóra $26,18 \mathrm{~cm}^{3}$ kaptunk. Így a végső szabad térfogat értéke $221,65 \mathrm{~cm}^{3}$ volt.

$\mathrm{Az}$ 5.13. ábrán látható, hogy az elméleti nyomásemelkedésnek 100\%-os konverzió esetén $425 \mathrm{kPa}$ értéknél kellett volna tetőznie. Ehhez képest a végső nyomásérték (fekete vonal) a kapott GTM görbe szerint $388 \mathrm{kPa}$ volt, ami 91.3 \%-os konverziót jelent. Ez azzal magyarázható, hogy az őrlőedény falára kitapadt reaktánsok zárványokat képeznek, melynek anyagtartalma nem alakul át (2.8.2.3 fejezet). 


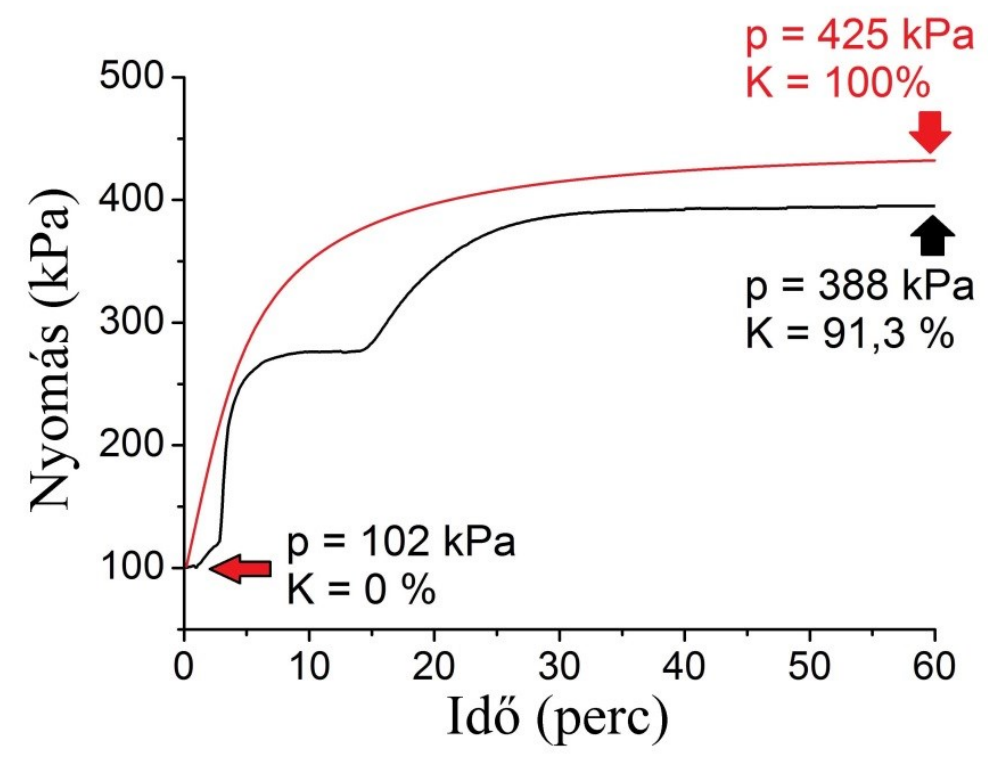

5.13. ábra: a fekete görbe a GTM által rögzített nyomásváltozást mutatja az $\mathrm{SnCl}_{2}$ és $\mathrm{Na}_{2} \mathrm{CO}_{3}$ 1:1 mólarányú mintája esetén. A piros görbe ugyanennek az összetételnek az elméleti lefutását mutatja.

A vártnál kisebb végső nyomásértéknél is szembetűnőbb különbség, hogy a mért nyomás-idő görbe lefutása nagyon eltér a másodrendü kinetikától. A kezdeti lassabb nyomásemelkedést (1-3 perc) az őrlemény inhomogenitása okozza, ennyi idő szükséges a homogén reakcióelegy kialakulásához. Ezután a reakciósebesség ugrásszerüen megnő a reaktánsok nagy mennyisége miatt a másodrendủ reakciók kinetikájának megfelelően. A nyomás emelkedése azonban az 5. perctől lelassul, majd a 15. percig a nyomás nem változik. Ebből arra következtethetnénk, hogy a reakciósebesség értéke nulla, holott a konverzió még messze van a $100 \%$-tól. A 15. perc után $(\mathrm{p}=275 \mathrm{kPa}$ körül) viszont a nyomás újra emelkedik, ekkor már közelítőleg a várt lefutáshoz hasonló módon, egyre lassuló reakciósebességet mutatva. A 30. perctől lényeges változást már nem tapasztalhatunk. Egyes őrléseket további 3 órán át folytattuk, de egyetlen esetben sem regisztráltunk további nyomásváltozást (a súrlódásból eredő hőmérséklet okozta minimális emelkedésen kívül).

Fontos megemlíteni, hogy ezt a jelenséget a mechanokémiai szakirodalom egyáltalán nem tárgyalja. Tudomásom szerint első kimutatása a jelen munkában történt és magyarázatát is itt kíséreljük meg először. Ezért a következőkben a magyarázat alátámasztásához nem tudok irodalmi segítségre támaszkodni. $\mathrm{Az} \quad \mathrm{SnO}_{2}$ szintézise közben detektált nyomásemelkedés-anomáliát később más anyagok előállítása során is megfigyeltük. A közös minden esetben a $\mathrm{Na}_{2} \mathrm{CO}_{3}$ (és a $\mathrm{NaCl}$ mátrix) használata volt. A jelenség értelmezése érdekében az eddigi beállításokkal megegyező őrlési sorozatot készítettünk egyre növekvő 
$\mathrm{Na}_{2} \mathrm{CO}_{3}$ tartalom mellett úgy, hogy a karbonátot a sztöchiometrikus aránytól 10\% lépésközökkel annak kétszereséig adtuk feleslegben $\mathrm{az} \mathrm{SnCl}_{2}$ és $\mathrm{NaCl}$ mellé (5.2. táblázat).

\begin{tabular}{c|c|c|c|c} 
Minta jele & $\mathrm{Na}_{2} \mathrm{CO}_{3}$ felesleg & $\mathrm{SnCl}_{2} \times 2 \mathrm{H}_{2} \mathrm{O}(\mathrm{g})$ & $\mathrm{Na}_{2} \mathrm{CO}_{3}(g)$ & $\mathrm{NaCl}(g)$ \\
\hline $\mathrm{A}$ & $(+0 \%)$ & & 3,0 & 20,62 \\
$\mathrm{~B}$ & $(+10 \%)$ & & 3,3 & 20,32 \\
$\mathrm{C}$ & $(+20 \%)$ & & 3,6 & 20,02 \\
$\mathrm{D}$ & $(+30 \%)$ & & 3,9 & 19,72 \\
$\mathrm{E}$ & $(+40 \%)$ & & 4,2 & 19,42 \\
$\mathrm{~F}$ & $(+50 \%)$ & \multirow{2}{*}{6,38} & 4,5 & 19,12 \\
$\mathrm{G}$ & $(+60 \%)$ & & 4,8 & 18,82 \\
$\mathrm{H}$ & $(+70 \%)$ & & 5,1 & 18,52 \\
$\mathrm{I}$ & $(+80 \%)$ & & 5,4 & 18,22 \\
$\mathrm{~J}$ & $(+90 \%)$ & & 5,7 & 17,92 \\
$\mathrm{~K}$ & $(+100 \%)$ & & 6,0 & 17,62
\end{tabular}

5.2. táblázat: a nyomás-idő anomália értelmezése során vizsgált minták összetételei.

A $\mathrm{NaCl}$ örlési mátrixként szerepel az őrleményben. Reaktánsként nem vesz részt az $\mathrm{SnCl}_{2}$ és $\mathrm{Na}_{2} \mathrm{CO}_{3}$ átalakulásában, és nem is szennyezi a mintánkat, hiszen az alapreakció melléktermékeként $\mathrm{NaCl}$ is keletkezik. A kialakuló nanorészecskék elválasztása és az örlési energia közvetítése mellett ebben a sorozatban az őrlemény össztömegének állandó értéken tartása is a szerepe volt. Az egyre több $\mathrm{Na}_{2} \mathrm{CO}_{3}$ miatt az örlemény össztömege ugyanis emelkedne, ennek hatását kompenzálni kellett. $\mathrm{A} \mathrm{NaCl}$ tömegét arányosan csökkentve tartottuk a reakcióelegy össztömegét állandó értéken $(30 \mathrm{~g} \pm 0,01 \mathrm{~g})$. Az egyes mintákat (amennyiben ez szükséges volt) őrlés után $600{ }^{\circ} \mathrm{C}$-on hökezeltük, majd desztillált vizes mosással távolítottuk el a maradék kiindulási anyagokat és a melléktermékeket. Végül a terméket centrifugáltuk és szobahőmérsékleten légkeverés mellett szárítottuk egy éjszakán át.

A fenti mintasort először 500 rpm fordulatszám mellett készítettük el. Az eredményeket az 5.14. ábra bal paneljén mutatom be. 

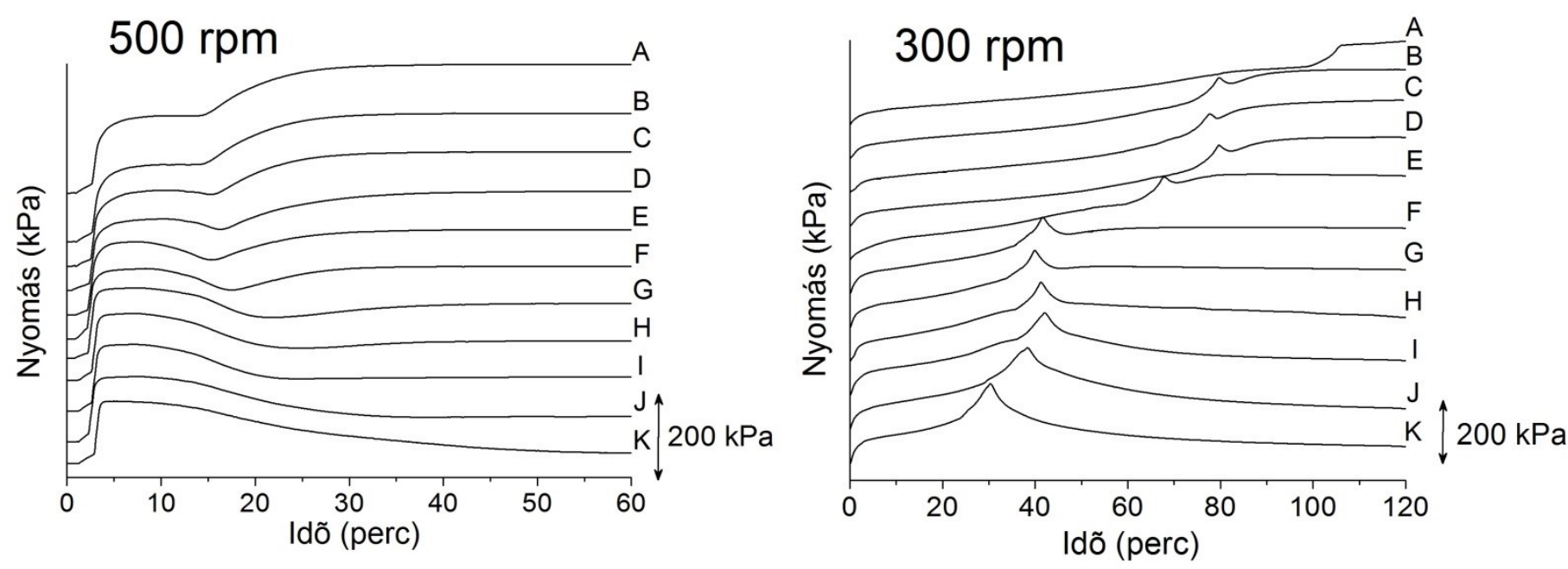

5.14. ábra: az 500 (balra) és 300 (jobbra) rpm fordulatszám mellett felvett őrlési sorozatokról készült, egyre nagyobb $\mathrm{Na}_{2} \mathrm{CO}_{3}$ felesleg mellett (A: $+0 \%$, B: $\left.+10 \% \ldots \mathrm{K}:+100 \%\right)$ rögzített nyomás-idő görbék. A görbék a jobb átláthatóság érdekében el lettek tolva az ordináta tengely mentén.

Jól látható, hogy a kezdeti hasonló nyomásemelkedést egy, a $\mathrm{Na}_{2} \mathrm{CO}_{3}$ felesleg növelésével összhangban álló csökkenő tendencia követ. Ez eleinte („B-F” minták) a 15-20. perc között egy időben egyre jobban eltolódó depresszióban mutatkozik meg, melyet még visszafogott nyomásemelkedés követ. Nagyobb $\mathrm{Na}_{2} \mathrm{CO}_{3}$ feleslegnél („G-J” minták) a második nyomásemelkedés elmarad, így a végső nyomás megközelíti a kiindulási ( 102 kPa) éréket.

Mivel szemmel láthatóan az őrlés első 30 percében történnek a lényegi változások, ezért a jobb felbontás érdekében csökkentettük az őrlés sebességét 500-ról 300 rpm fordulatszámra. Így a kritikus szakaszt egy $\sim 75$ perces tartományra nyújtottuk (5.14. ábra jobb panelje). Az 500 rpm fordulatszámon készült sorozat esetén tapasztalt nyomásvisszaesés a 15. perc után itt sokkal jobban kirajzolódik, sőt időben el is tolódik a karbonátfelesleg függvényében. Emellett megfigyelhetünk minden minta esetén egy $290 \mathrm{kPa}$ érték körüli lokális nyomásmaximumot. Az új eredmények könnyebb értelmezhetősége érdekében grafikonokon ábrázoltam az egyes mintákhoz tartozó végső nyomást, valamint a lokális nyomásmaximumok értékeit az elérésükhöz szükséges idő függvényében (5.15. ábra). Akár az 500, akár a 300 rpm fordulatszám mellett örölt mintasort tekintjük, a karbonátfelesleg növelésével arányosan csökkent a végső nyomásérték. Az $1: 1 \mathrm{SnCl}_{2}: \mathrm{Na}_{2} \mathrm{CO}_{3}$ mólarányú minta (A) esetén $400 \mathrm{kPa}$ körüli végső nyomást mértünk. Ez az érték az $1: 2 \mathrm{SnCl}_{2}: \mathrm{Na}_{2} \mathrm{CO}_{3}$ mólaránynál $(\mathrm{K}) 150 \mathrm{kPa}$ alá esik a fordulatszámtól függetlenül. Kijelenthetjük, hogy $10 \%$ karbonát-feleslegenként hozzávetőleg $25 \mathrm{kPa}-\mathrm{lal}$ esik a végső nyomás értéke. Az 5.15. ábra jobb oldali grafikonján a 
két fordulatszám mellett végzett őrléseknél tapasztalt lokális nyomásmaximumokat, és az elérésükhöz szükséges időket tüntettük fel. $\mathrm{A} \mathrm{Na}_{2} \mathrm{CO}_{3}$ felesleg mennyiségétől kvázi függetlenül a nyomás minden esetben a $290 \mathrm{kPa}$ elérése után kezdett csökkenni $300 \mathrm{rpm}$ fordulatszám mellett. 500 rpm fordulatszámon ez 275-260 kPa közt történt. Ez hozzávetőleg 55-57 \%-os konverziót jelent, ami egyezik az 1:1 arányú minták lépcsőzetes nyomásgrafikonján megfigyelt második nyomásemelkedés értékével, melyet korábban az 5.14. ábrán mutattam be.

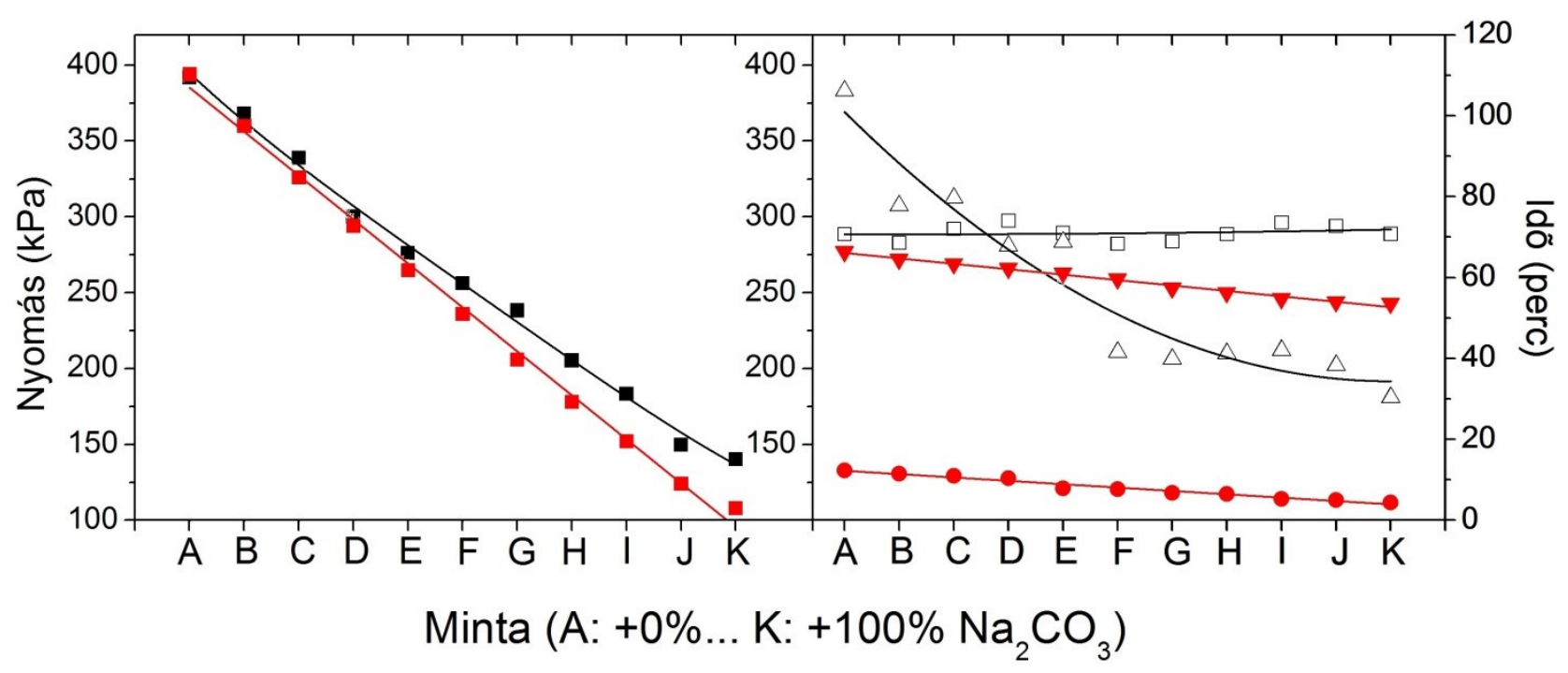

5.15. ábra: (balra): a (ロ) 300 és ( leolvasott végső nyomásértékek. (jobbra): a lokális $p_{\max }$ értékek ( $\square 300 \mathrm{rpm}, \boldsymbol{\nabla}$ 500rpm) és az ennek eléréséhez szükséges idő ( $\Delta 300 \mathrm{rpm}, \bullet 500 \mathrm{rpm})$.

Lényeges eltérést fedezhetünk fel még a lokális nyomásmaximum eléréséhez szükséges időben is, ami a $\mathrm{Na}_{2} \mathrm{CO}_{3}$ felesleg növelésével egyre rövidül. Ez a reakcióidő elnyújtása miatt a 300 rpm kísérletsorozatban jobban kirajzolódik (5.15. ábra). Ott 107 percről („,A” minta) egészen 30 percig („,K” minta) csökken ez az időtartam ( $\Delta$ adatsor). A lokális nyomásmaximum időbeni eltolódása a $\mathrm{Na}_{2} \mathrm{CO}_{3}$ feleslegével magyarázható. Mivel az egyre nagyobb mennyiségben van jelen a rendszerben, így annak is nő az esélye, hogy $\mathrm{SnCl}_{2}$ részecskék $\mathrm{Na}_{2} \mathrm{CO}_{3}$ szemcsével találkoznak, ezért a reakció gyorsul a karbonát feleslegének növelésével. Ez általános jelenség másodrendü reakciók esetén: az egyik prekurzort feleslegben adagolva megnöveljük a reakciósebességet és így gyorsíthatjuk a termékképződést. Még nagyobb felesleggel egészen pszeudo-elsőrendűvé alakíthatjuk rendszerünket. Ugyanakkor ez sem a lokális maximum kialakulását, sem a kétlépcsős nyomásemelkedést, sem pedig a reakció második felében tapasztalható nyomáscsökkenést nem magyarázza meg. 
Tudjuk tehát, hogy a $\mathrm{Na}_{2} \mathrm{CO}_{3}$ a kiváltója a nyomás emelkedésében jelentkező anomáliának. Mintáinkat a következőkben részletesen analizáltuk annak érdekében, hogy megismerjük a jelenség hátterét. A minták röntgen diffraktogramjai alapján azt vizsgáltuk, hogy a $\mathrm{Na}_{2} \mathrm{CO}_{3}$ felesleg a végtermék minőségét befolyásolva okozhatja-e a tapasztalt változást. Az 5.16. ábra bal paneljén a 300 rpm fordulatszámon őrölt „A” jelü minta röntgen diffraktogramjait láthatjuk: legfelül közvetlenül az őrlés után, alatta a kiégetés után, majd legalul a már desztillált vízzel is mosott minta szerepel. Előző kettő esetben a $\mathrm{NaCl}$ jelenléte miatt csak a kiégetett mintában fedezhetjük fel az $\mathrm{SnO}_{2}$ legintenzívebb reflexióit $2 \Theta 26,5^{\circ}$ (110), 33, $8^{\circ}(101), 37,9^{\circ}$ (200) és 51,8 (211) értékeknél. Mosás után már kizárólag az $\mathrm{SnO}_{2}$-re jellemző reflexiókat láthatjuk, melyek közül a kisebb intenzitásúak is megjelennek a diffraktogramon. A legnagyobb $\mathrm{Na}_{2} \mathrm{CO}_{3}$ felesleggel készült „K” minta esetében is ugyanezeket a reflexiókat azonosítottuk. Ahogyan az 5.16. ábra jobb paneljén látható, a $\mathrm{Na}_{2} \mathrm{CO}_{3}$ mennyiség emelésével sem jelennek meg az XRD vizsgálattal kimutatható új fázisok a végtermékben.
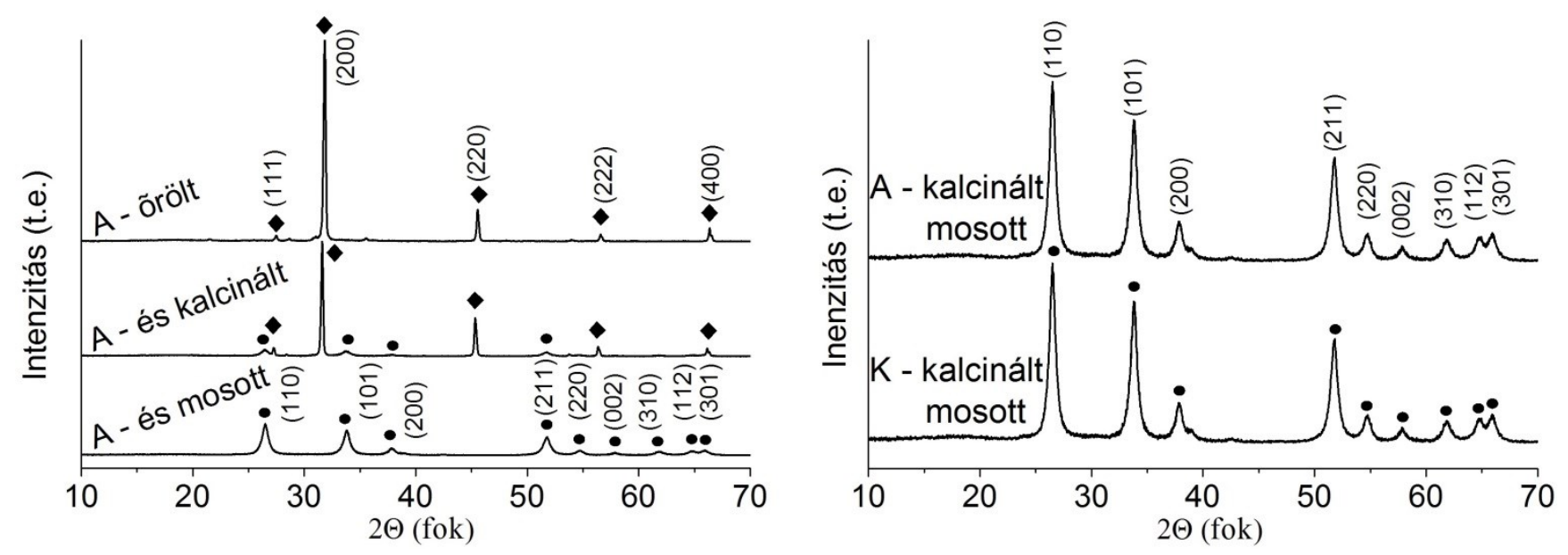

5.16. ábra: a $300 \mathrm{rpm}$ fordulatszám mellett őrölt „,A” minták őrlés, kalcinálás és mosás utáni (balra), valamint az „A” és „K” jelü minták végtermékeinek röntgen diffraktogramjai (jobbra). $\bullet: \mathrm{NaCl}$ reflexiói; $\bullet: \mathrm{SnO}_{2}$ reflexiói.

A következő lépésben az őrlési folyamat különböző időpontjaiban vett „A” és „K” minták FT-IR spektrumait rögzítettük. Az 5.17. ábrán feltüntettem az egyes mintavételi pontokat és a hozzájuk tartozó FT-IR spektrumokat. Természetesen minden mintavételezés után új szintézist indítottunk el, azaz nem a megszakított őrlést folytattuk. Az „A” sorozat első két pontján vett mintákban ( 1 és 20 perc után) nagy mennyiségü $\mathrm{Na}_{2} \mathrm{CO}_{3}$ mutatható ki, amit az 1445 és $877 \mathrm{~cm}^{-1}$ hullámszámnál rögzített csúcsok mutatnak (o). Az örlési idővel növekvő 
intenzitású $607 \mathrm{~cm}^{-1}$-en jelentkező elnyelés az Sn-O kötés rezgéséből származik, és a termék dúsulásával egyre intenzívebbé válik (x). Az $1622 \mathrm{~cm}^{-1}$ hullámszámnál látható csúcs az $\mathrm{SnCl}_{2}$-ból kilépő kristályvízhez köthető O-H kötések elnyelése $(\bullet)$. Ez a nyomás ugrásánál vett mintákban (90, 100 és 108. perc) erősödik fel, ahol a $\mathrm{Na}_{2} \mathrm{CO}_{3}$-ra jellemző csúcsok már nem felfedezhetőek. Lényegében az „A” minta készítése közben jól követhető, ahogyan a kiindulási anyag $\left(\mathrm{Na}_{2} \mathrm{CO}_{3}\right)$ mennyisége csökken, a terméké $(\mathrm{SnO})$ pedig nő.

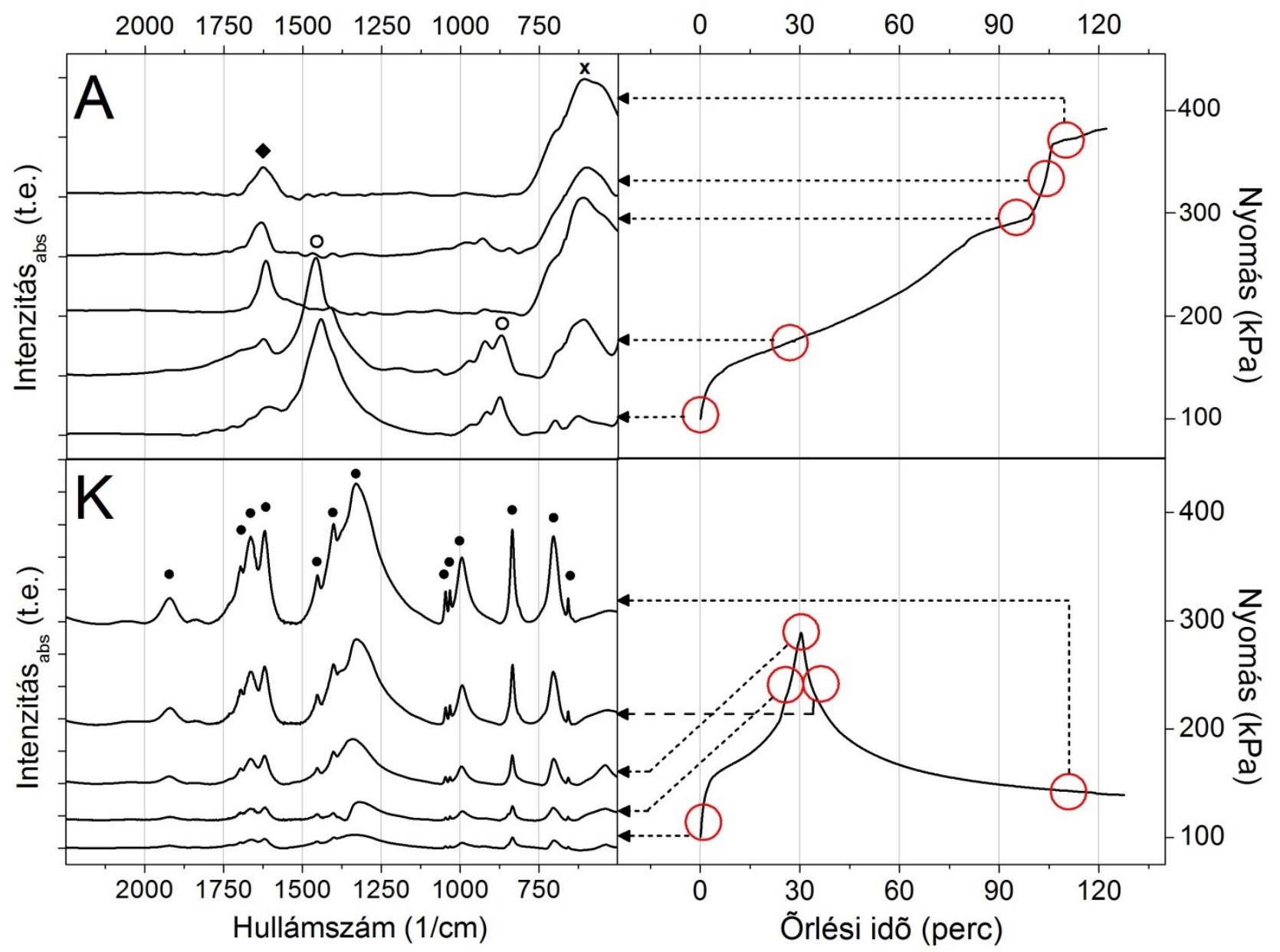

5.17. ábra: az „A” (fent) és „K” (lent) őrlemények szintézis közben vett mintáinak FT-IR spektrumai. Jobb oldalon a GTM görbéken jelölt mintavételezési időpontok. ×: SnO-hoz tartozó elnyelések; ○: $\mathrm{Na}_{2} \mathrm{CO}_{3}$-hoz tartozó elnyelések; $\bullet: \mathrm{H}_{2} \mathrm{O}$-hoz tartozó elnyelések;

•: $\mathrm{NaHCO}_{3}$-hoz tartozó elnyelések.

A „K” jelü mintából vett sorozat egyes spektrumain ezzel szemben alapvető eltéréseket figyelhetünk meg. A kétszeres $\mathrm{Na}_{2} \mathrm{CO}_{3}$ mennyiség miatt a keletkező $\mathrm{CO}_{2}$ és $\mathrm{H}_{2} \mathrm{O}$ már 1 perc után $\mathrm{NaHCO}_{3}$-tá alakulhat. A karbonát bősége miatt lehetőség van a $\mathrm{NaHCO}_{3}$ felhalmozódására, amit annak egyre intenzívebb elnyelései is igazolnak. 
$\mathrm{Az}$ 5.17. ábra bal alsó grafikonján látható elnyelések a $\mathrm{NaHCO}_{3}$ különböző rezgéseihez tartoznak: $662 ; 698 ; 838 ; 1000 ; 1035 ; 1050 ; 1330 ; 1410 ; 1460 ; 1620 ; 1660 ; 1695$; $1905 \mathrm{~cm}^{-1} \cdot{ }^{218}$ Mellette az Sn-O kötés elnyelése is egyre kifejezettebb az idő múlásával, de intenzitása lényegesen kisebb. Mindebből úgy tünik, hogy a cserebomlási reakcióban keletkező $\mathrm{CO}_{2}$ egy része $\mathrm{NaHCO}_{3}$ formájában halmozódik fel, ezért nem növeli az edényben a nyomást.

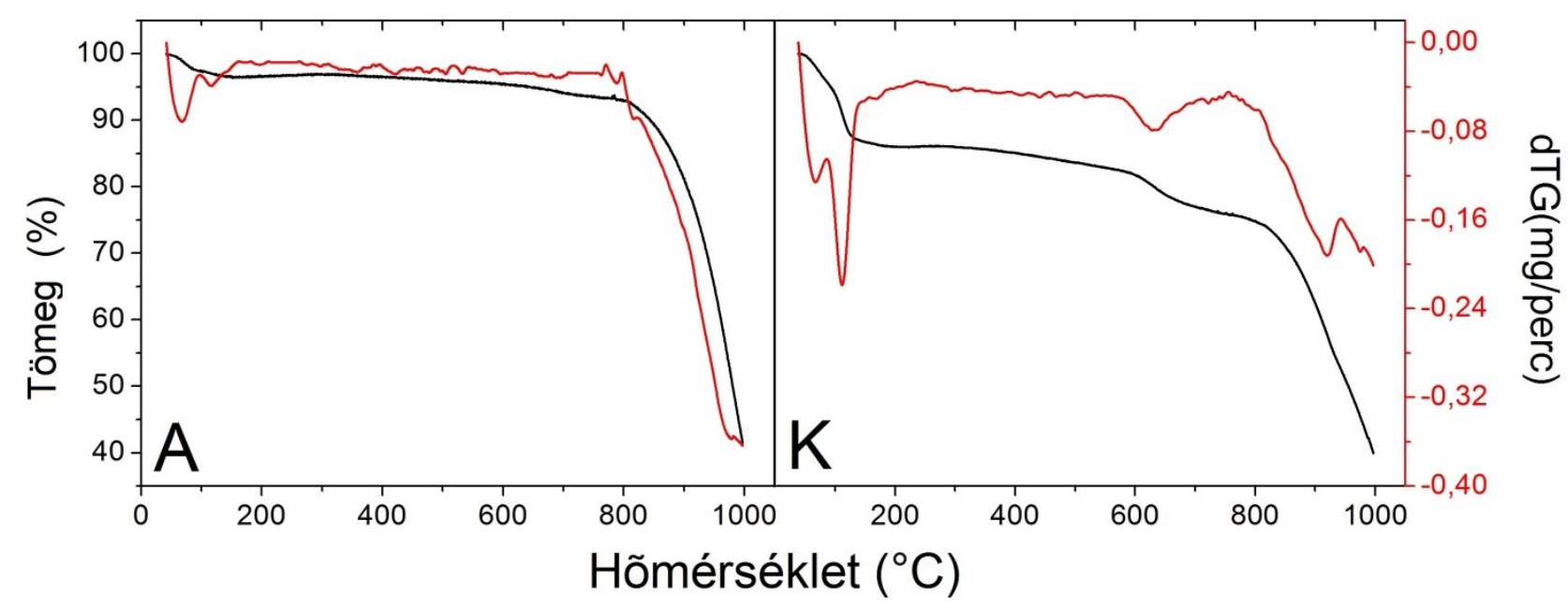

5.18. ábra: az „A” (balra) és „K” (jobbra) jelü minták TG-dTG görbéi.

Ezt a felvetést a FT-IR eredményeken felül termogravimetriás méréssel is igyekeztünk alátámasztani. Ehhez a fenti összetételü (A és K) örlések 120. percében vett mintáit használtuk fel, mert ezekben feltehetőleg már minden reaktáns átalakult. Az eredményeket az 5.18. ábrán láthatjuk. Az „A” mintában a felfütés elején látható minimális tömegcsökkenést a mintában maradt víz okozza. Ezután $\sim 800{ }^{\circ} \mathrm{C}$-ig nincsen lényeges változás, majd a minta jelentős részét kitevő (a teljes tömeg 2/3-a) $\mathrm{NaCl}$ evaporációja látható. Egyéb tömegvesztés nem történik, hiszen ez a sztöchiometrikus összetételü reaktánselegyből készített minta csak $\mathrm{H}_{2} \mathrm{O}$-t, NaCl-t és $\mathrm{SnO}_{2}$-t tartalmaz. A „K” jelü minta ezzel szemben sokkal nagyobb tömegcsökkenést mutat már az első $150{ }^{\circ} \mathrm{C}$-os tartományban. Ezt kis részben a szabad víz, nagyobb részben az $50{ }^{\circ} \mathrm{C}$ felett $\mathrm{NaHCO}_{3}$-ból kilépő $\mathrm{CO}_{2}$ és $\mathrm{H}_{2} \mathrm{O}$ okozza. A $\mathrm{NaHCO}_{3}$ termikus bomlása egészen $200{ }^{\circ} \mathrm{C}$-ig tart, miközben $\mathrm{Na}_{2} \mathrm{CO}_{3}$ keletkezik. ${ }^{219} \mathrm{~A} \quad \mathrm{Na}_{2} \mathrm{CO}_{3}$ tartalom $800{ }^{\circ} \mathrm{C}$ felett tovább bomlik $\mathrm{CO}_{2}$ és $\mathrm{Na}_{2} \mathrm{O}$-ra, miközben a $\mathrm{NaCl}$ okozta tömegcsökkenés is megfigyelhető. A termogravimetriás mérések tehát alátámasztják azt a feltételezést, hogy a keletkező $\mathrm{CO}_{2} \mathrm{NaHCO}_{3}$ formájában raktározódik el. 


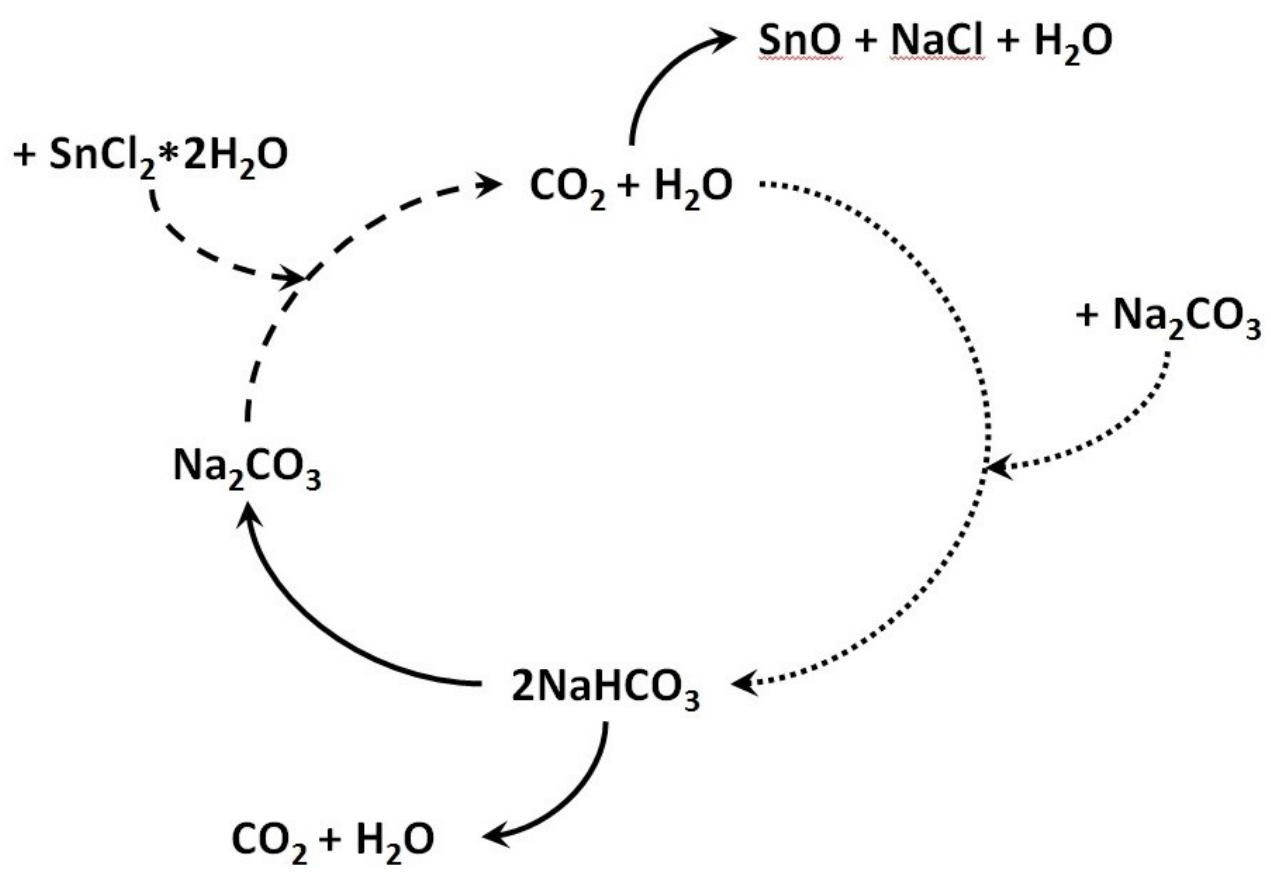

5.19. ábra: a GTM görbe vizsgálata során kialakult folyamatok ábrázolása. A szaggatott vonal az $\mathrm{SnCl}_{2}$ és $\mathrm{Na}_{2} \mathrm{CO}_{3}$ reakcióját, a pöttyözött vonal az éppen feleslegben lévő $\mathrm{Na}_{2} \mathrm{CO}_{3}$ reakcióját a $\mathrm{CO}_{2}$-dal és vízzel, míg a folytonos vonal az előző során kialakult $\mathrm{NaHCO}_{3}$ bomlását mutatja.

A folyamat általunk javasolt sémáját az 5.19. ábrán foglaltam össze. $\mathrm{Az} \mathrm{SnCl}_{2}$ és $\mathrm{Na}_{2} \mathrm{CO}_{3}$ reakciójából származó $\mathrm{CO}_{2}$ és a fémsóból kilépő kristályvíz (szaggatott vonal) a szabad $\mathrm{Na}_{2} \mathrm{CO}_{3}$-tal $\mathrm{NaHCO}_{3}$-t képezhet (pöttyözött vonal). Ez gyorsan el is bomlik, így a két kiindulási anyagok közti reakció nem áll le (ha ugyanis leállna, akkor a 100\% konverziótól lényegesen alacsonyabbat mérnénk, feltehetőleg 50\% körüli értéket). Mindez a nyomás növekedésében egy lassuló tendenciaként jelenik meg, mivel a keletkező $\mathrm{CO}_{2}$ egy része azonnal átalakul $\mathrm{NaHCO}_{3}$-á, majd a bikarbonát bomlásával újra felszabadul. Az egyenletes növekedésnek a $\mathrm{Na}_{2} \mathrm{CO}_{3}$ mennyisége szab korlátot, mivel ahelyett, hogy $\mathrm{SnCl}_{2}$-dal reagálva $\mathrm{CO}_{2}$-t képezne, azt elnyeli a víz jelenléte miatt. Végül a $\mathrm{Na}_{2} \mathrm{CO}_{3}$ fogyásával a $\mathrm{NaHCO}_{3}$ utánpótlás fokozatosan megszünik, ami az addig elraktározott $\mathrm{CO}_{2}$ felszabadulását okozza (folytonos vonal). Ez az oka, hogy a sztöchiometrikushoz hasonló összetételü reaktánselegyeknél a nyomás-idő görbe két másodrendü kinetikai görbe összegének látszik. Dupla mennyiségű $\mathrm{Na}_{2} \mathrm{CO}_{3}$ viszont már nem szab határt a $\mathrm{NaHCO}_{3}$ keletkezésének, tehát amennyivel több $\mathrm{Na}_{2} \mathrm{CO}_{3}$ van a rendszerben, azzal egyenértékü (anyagmennyiségben) $\mathrm{CO}_{2}$ nyelödik el. Ez kétszeres $\mathrm{Na}_{2} \mathrm{CO}_{3}$ mennyiségnél a teljes $\mathrm{CO}_{2}$ készletet jelenti, így a rendszer az őrlés végére eléri, vagy megközelíti a kiindulási nyomás értékét ( 102 kPa), ahogyan azt az 5.14. ábrán láthattuk is. 
Tekintettel a mechanokémiai nanorészecske szintézis terjedésére és az in situ nyomásmérésnek a reakciókövetésben betöltött kiemelt szerepére, nagyon fontosnak tartom ezt az eredményt. Reakciók tervezésénél a jelenséget figyelembe kell venni, különösen akkor, ha a nyomás változásából származó információkból szeretnénk reakciókinetikai következtetéseket levonni. Esetünkben a jelenség figyelembevételével a korábban részletezett konverziószámító módszer már biztonsággal használható a reakció végpontjának azonosítására.

Amennyiben rendszerünket GTM fejjel egészítjük ki, úgy azt alapvetően két dologra használhatjuk: 1) speciális gázösszetételben őrölhetünk megfelelő nyomáson, vagy 2) az eddig bemutatott módon nyomon követhetjük a rendszerünkben bekövetkező nyomás- és hőmérsékletváltozást. Hasanpour és társai $\mathrm{Fe}$ és $\mathrm{Bi}_{2} \mathrm{O}_{3}$-t őröltek $\mathrm{Bi}^{-} \mathrm{Fe}_{3} \mathrm{O}_{4}$ szintéziséhez. ${ }^{203}$ Levegő és argon gázban elvégzett kísérleteikben az őrlőedény felmelegedéséből származó nyomásemelkedést, emellett pedig az $\mathrm{O}_{2}$ tartalom csökkenéséből származó nyomáscsökkenést regisztráltak. A hőmérsékletgörbe határozott emelkedése, majd esése okaként a súrlódásból származó, majd a bizmut redukciója során elvont hőt $(\Delta \mathrm{H}=-58,5 \mathrm{~kJ} / \mathrm{mol})$ azonosították. Ez jó példa a GTM használatának előnyeire, hiszen egyrészt már egy őrlésből látható volt a reakció időigénye (kb. 4 óra), valamint az oxigén elvonása a kívánt termék megjelenését sejtette (igaz ennek kijelentéséhez mélyrehatóbb analízis szükséges). Ugyanakkor itt is, és Gheisari és társai munkájában is a nyomásemelkedésből levont következtetések nem feltétlenül helytállóak. ${ }^{220}$ Mindkét esetben a 10-15 kPa nyomásemelkedést az őrlemény összetevőinek reakciójával azonosítják, holott azt 30-40 ${ }^{\circ} \mathrm{C}$-os hömérsékletemelkedés kíséri. Könnyen belátható, hogy a nyomásváltozást a zárt őrlőedényben ez a plusz hő okozza.

Doppiu, valamint Castro és társai $\mathrm{MgH}_{2}$-t állítottak elő nagynyomású $\mathrm{H}_{2}$ gázban. ${ }^{221,} 222$ A GTM fej segítségével jól követhető volt a reakció előrehaladása. Közel $1500 \mathrm{kPa}$ nyomásról indulva a $\mathrm{H}_{2}$ gáz fogyását tapasztalták. Ha a nyomás eléri az előre kalkulált értéket, a teljes konverzió jó közelítéssel megbecsülhető. Coste és társai $\mathrm{Al}_{2} \mathrm{O}_{3}$ és $\mathrm{TiO}_{2}$ porkeveréket őröltek össze közel 20 órán keresztül. ${ }^{204}$ A kezdeti nyomásemelkedés a hőmérséklet növekedésével egyértelmüen magyarázható volt, azonban a 2. órától közel az őrlés végéig a nyomás a $p_{\max }$-hoz képest mintegy $20 \%$-kal csökkent. Ök ezt gáztérben található $\mathrm{O}_{2}$ adszorpciójával magyarázták, amit az őrlés során kialakuló nagy felületü porkeverék okoz. Ezt azonban kizárja az a későbbi eredmény, miszerint a különböző összetételű porkeverékek fajlagos felületének növekedése nagyon eltért egymástól, ellenben a nyomás csökkenésének teljes átfedésével. Jelen esetben tehát a nyomásváltozásból levont 
következtetések nem feltétlenül helyesek és további vizsgálatot igényelnek. Mindez jól rávilágít arra, hogy a GTM által megjelenített eredményeket minden esetben kiegészítő vizsgálatokkal szükséges alátámasztani.

A $\mathrm{Na}_{2} \mathrm{CO}_{3}$-ot gyakran alkalmazzák cserebomlásos mechanokémiai reakció prekurzoraként. $^{223,224}$ Sokszor nem pusztán a termék előállítása a cél, hanem a reakció kinetikáját is monitorozzák valamilyen analitikai módszerrel. A prekurzorok és végtermékek mennyiségének meghatározása alapvetően helyes következtetésre vezethet minket, amennyiben tisztában vagyunk azok pontos összetételével. Vidojković és társai $\mathrm{Na}_{2} \mathrm{SeO}_{3}$ szintézise közben időközönként felvették az őrlemény IR-spektrumát. ${ }^{225}$ Elemzésükben a $\mathrm{Na}_{2} \mathrm{SeO}_{3}$ elnyelései valóban a termék jelenlétét mutatták, de nem tértek ki a $\mathrm{NaHCO}_{3}$ megjelenésére, ami az őrlés 240. percétől valószínűsíthető. Ez még 330 perc múlva is fellelhető az őrlemény IR-spektrumán, tehát a $\mathrm{Na}_{2} \mathrm{CO}_{3}$ rezgései hiába gyengülnek, a $\mathrm{NaHCO}_{3}$ jelenléte bizonyítja, hogy még nem alakult át minden reakciópartner. Hasonló elemzést találhatunk Liu és társai, borkősav és $\mathrm{Na}_{2} \mathrm{CO}_{3}$ reakciójának vizsgálatára irányuló munkájában. ${ }^{226}$ Singh és társai termogravimetriás elemzést végeztek a $\mathrm{K}_{0.5} \mathrm{Na}_{0.5} \mathrm{NbO}_{3}$ szintézise végén kapott örleménnyel. ${ }^{227}$ Hasonlóan a mi eredményeinkhez, ők is egy $135{ }^{\circ} \mathrm{C}$-ig tartó $8 \%$-os tömegcsökkenést regisztráltak, amit az őrlemény víztartalmához rendeltek. Holc és társai szintén niobátok előállításánál a TGA vizsgálatokat a távozó gázok elemzésével is kiegészítették és ebben a hőmérséklettartományban a víz mellett $\mathrm{CO}_{2}$ - $\mathrm{t}$ is kimutattak, amit adszorbeált gázként azonosítottak. Ezek megfelelnek az általunk korábban tapasztalt, a $\mathrm{NaHCO}_{3}$ bomlásából eredő gázokkal. A jelenség más mechanokémiai reakciók során is jelentkezett. ${ }^{190,228}$ Nagyon fontos tehát az örleményünk összetételének pontos ismerete, hogy az annak változásáról kapott információt helyesen értékelhessük ki. 


\subsection{Fém-oxid nanorészecskék előállítása}

Miután már képesek voltunk helyesen értelmezni a regisztrált nyomás-idő görbét, többféle fém-oxid nanorészecskét is sikeresen állítottunk elö. A GTM görbén jelentkező anomália megfejtése után azonban újabb furcsa jelenséget figyeltünk meg, ami nem a kísérleti rendszerünk hibájából, hanem egy külső forrásból származott. A kiindulási anyagok konverziós állapotát csak a helyes nyomásadatok leolvasásával vagyunk képesek meghatározni. Egy kísérletsorozat során azonban a GTM mérőfej által küldött jel először szakaszosan, majd végleg megszünt, ami a monitoron 2-3 kPa körüli állandósult zajként jelent meg (5.20. ábra). Miután kizártuk a mérőfej tápegységeinek lemerülését, továbbá a számítógép és a program hibáját, befejeztük az aktuális őrlést. Másnap a hiba nem jelentkezett és azóta sem figyeltünk meg újra.

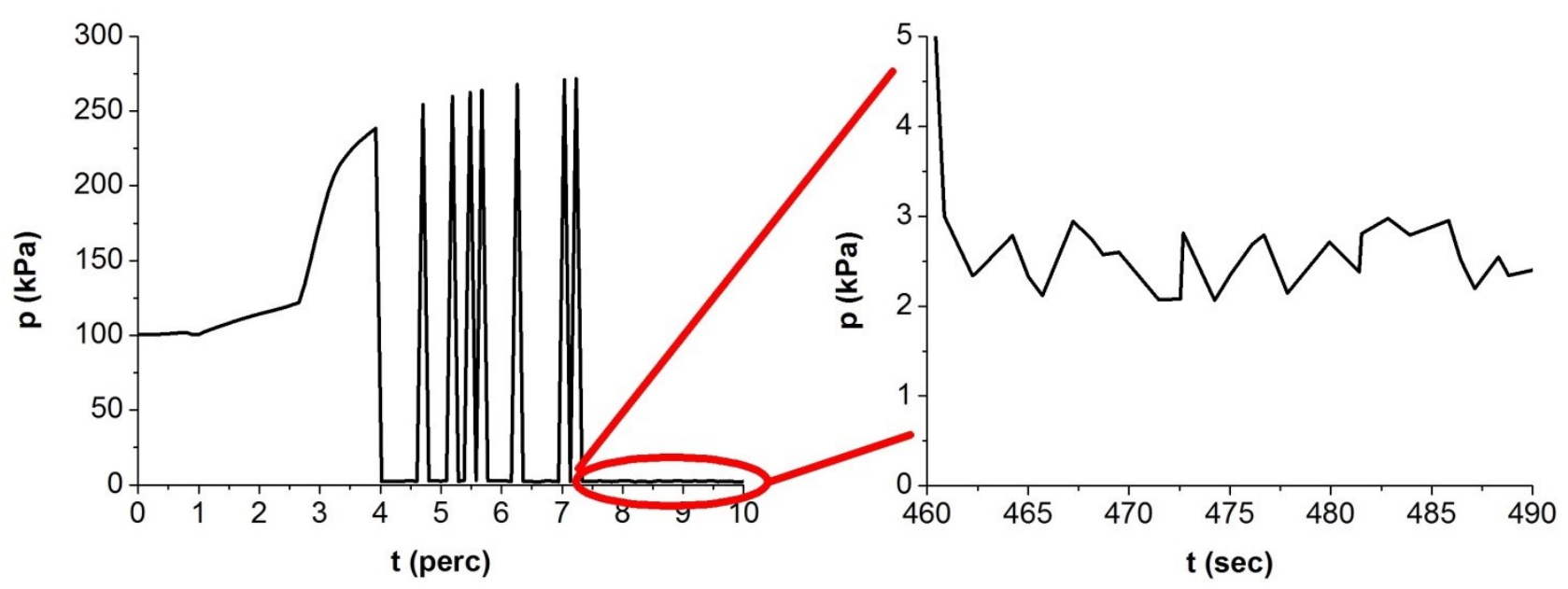

5.20. ábra: 2014.10.22-én rögzített GTM görbe. Balra az őrlés kezdete után 4 perceel jelentkező szünetek, majd jobbra a 7. perc után regisztrált zaj.

A szóban forgó őrlést 2014. október 22-én hajtottuk végre a délutáni órákban. A zajt 16 óra 45 perckor észleltük először. Mint kiderül, ebben az időben érte el a Földet egy korábbi napkitörés, pontosabban egy fler, ami a Nap „légkörének” hirtelen kifényesedését jelenti. A flerek nem járnak koronakidobódással, ugyanakkor nagymennyiségü töltött részecske juthat a bolygóközi térbe. A mi esetünkben egy X1.6 szintü kitörésről beszélhetünk, ami az ötfokozatú logaritmikus skála legerősebb szegmensét jelenti és hozzávetőleg $1,6 \bullet 10^{-3} \mathrm{~W} / \mathrm{m}^{2}$ erejü röntgensugárzásnak fele meg. Az eseményt a NOAA (National Oceanic and Atmospheric Administration) oldalán a naptevékenységi naplóban meg is találtuk (5.21. ábra). 


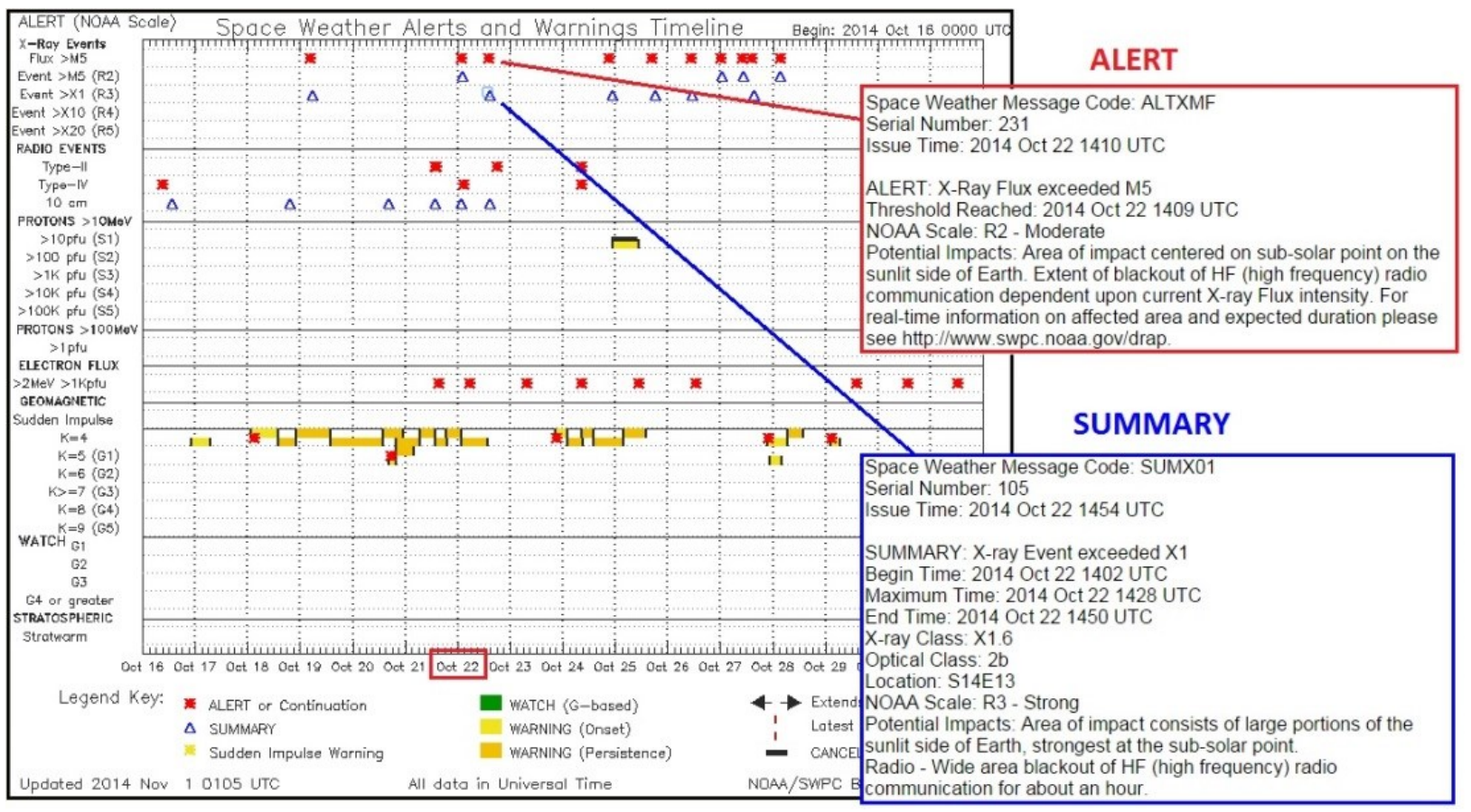

5.21. ábra: az eredeti NOAA által kiadott naptevékenység napló. Kiemelve a Földet elért X1.6-os erösségü kitörés figyelmeztetése és az eseményt összefoglaló táblázatot láthatjuk.

Az ilyen erősségü flerek zavart okoznak a magas frekvenciájú rádióhullámokkal kommunikáló eszközökben, amit az összefoglalás végén olvashatunk is. Mivel a GTM fej $433 \mathrm{MHz}$ frekvenciájú rádiójelet használ, az esemény erre is hatással volt. Az 5.21. ábrán láthatjuk, hogy UTC (Coordinated Universal Time) szerint a fler hatásának maximuma 14 óra 28 perckor történt. Mivel Szeged 20,15 hosszúsági fokra van ettől a ponttól ( 4 perc/fok), ez időben 80 perc eltolódást jelent. A nyári időszámítással korrigálva 140 perc eltérést kapunk, tehát a kitörés maximuma 16 óra 48 perckor érte el laborunkat, ami mivel délnyugati fekvésű, ekkor pont a Nap felé nézett, így a falak árnyékoló hatása sem csökkenthette a zavaró hatást.

Ritkaság, hogy egy kozmikus jelenségnek ennyire direkt hatását tapasztalhatjuk a mindennapi kísérleti munkában. Bár ilyen erősségü napkitörés aránylag ritkán éri el Földünket, a hatását mindenképpen számításba kell vennünk műszerünk elhelyezésénél. Lehetőleg más, rádiófrekvenciát zavaró eszköztől távol, és amennyiben lehetséges, nem Napnak kitett helyen telepítsük GTM mérőfejet használó malmunkat. 


\subsection{1 Ón-dioxid nanorészecskék előállítása}

A 4.2.3.1. fejezetben bemutatott reakció szerint két lépésben elöállított ón-dioxid nanokristályok szintézisét optimalizáltuk, valamint elvégeztük részletes jellemzésüket is. Ennek eredményeként egyszerre $\sim 4 \mathrm{~g}$ átlagosan $\sim 9 \mathrm{~nm}$ átmérőjü végterméket állítottunk elő.

$\mathrm{Az} \mathrm{SnO}_{2}$ nanorészecskék előállítása során a 4.2.1. fejezetben bemutatott (11) és (12) egyenletek segítségével meghatároztuk a reakció teljes lejátszódásakor kialakuló végső nyomást.

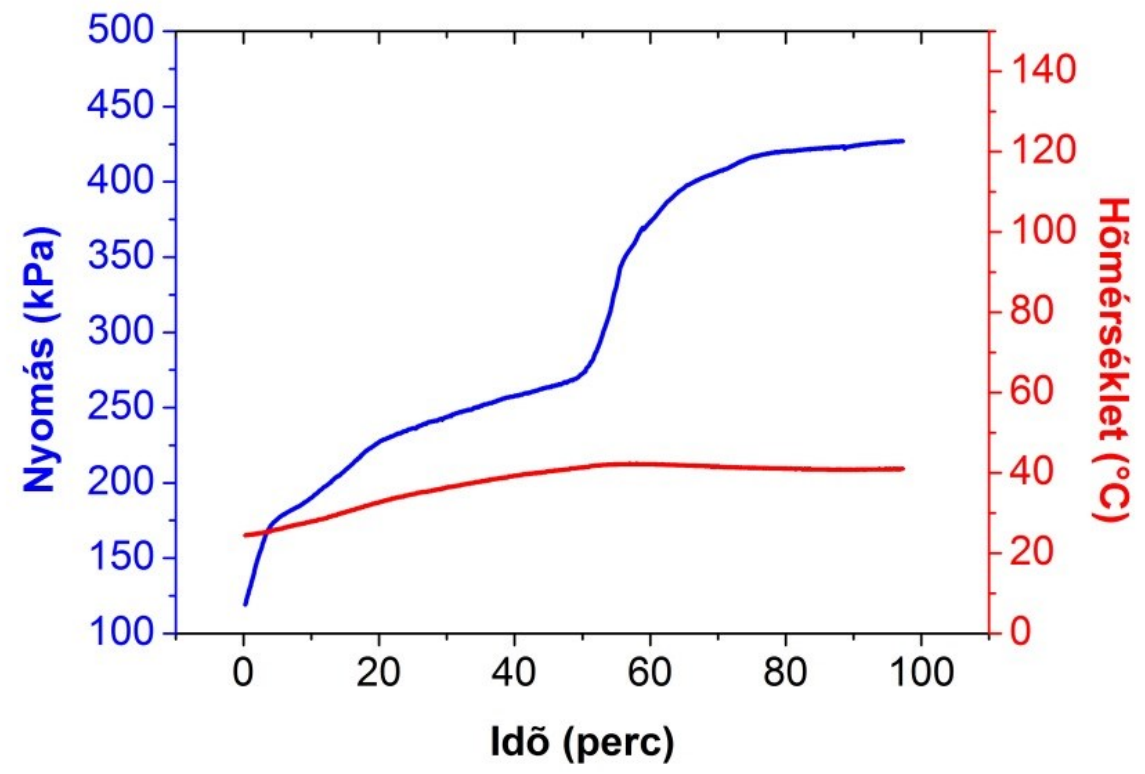

5.22. ábra: $\mathrm{SnO}_{2}$ szintézis közben regisztrált nyomás-idő (kék), illetve hőmérséklet-idő (piros) görbék.

$\mathrm{Az}$ 5.22. ábrán látható, hogy a nyomás $\mathrm{kb}$. $440 \mathrm{kPa}$ értéknél tetőzne (ezt később hosszabb mérésekkel pontosítottuk), de elmarad az előre kalkulált maximális nyomástól. A különbség a már korábban bemutatott őrleménykitapadás jelenségéből adódik, ami - a későbbi tapasztalatok alapján - átlagosan 5-10\%-os termékveszteséget okozott. A konverzió százalékos értékének számítására alkalmas egyenletet (12-13) később más reaktáns mennyiségek esetén is sikeresen alkalmaztuk.

Amellett, hogy a felszabaduló $\mathrm{CO}_{2}$ okozta nyomásemelkedésből következtetni tudtunk a reakció menetére, azt is meghatároztuk, hogy annak bizonyos pontjain már $\mathrm{SnO}_{2}$ vagy valamilyen más köztitermék van-e jelen a rendszerben. Ehhez a nyomásgörbét szakaszokra 
bontottuk és hét különböző időpontban mintát vettünk (természetesen minden alkalommal új szintézist indítva). A hét mintát rendre „a-g” betükkel jelöltük meg (5.23. ábra).
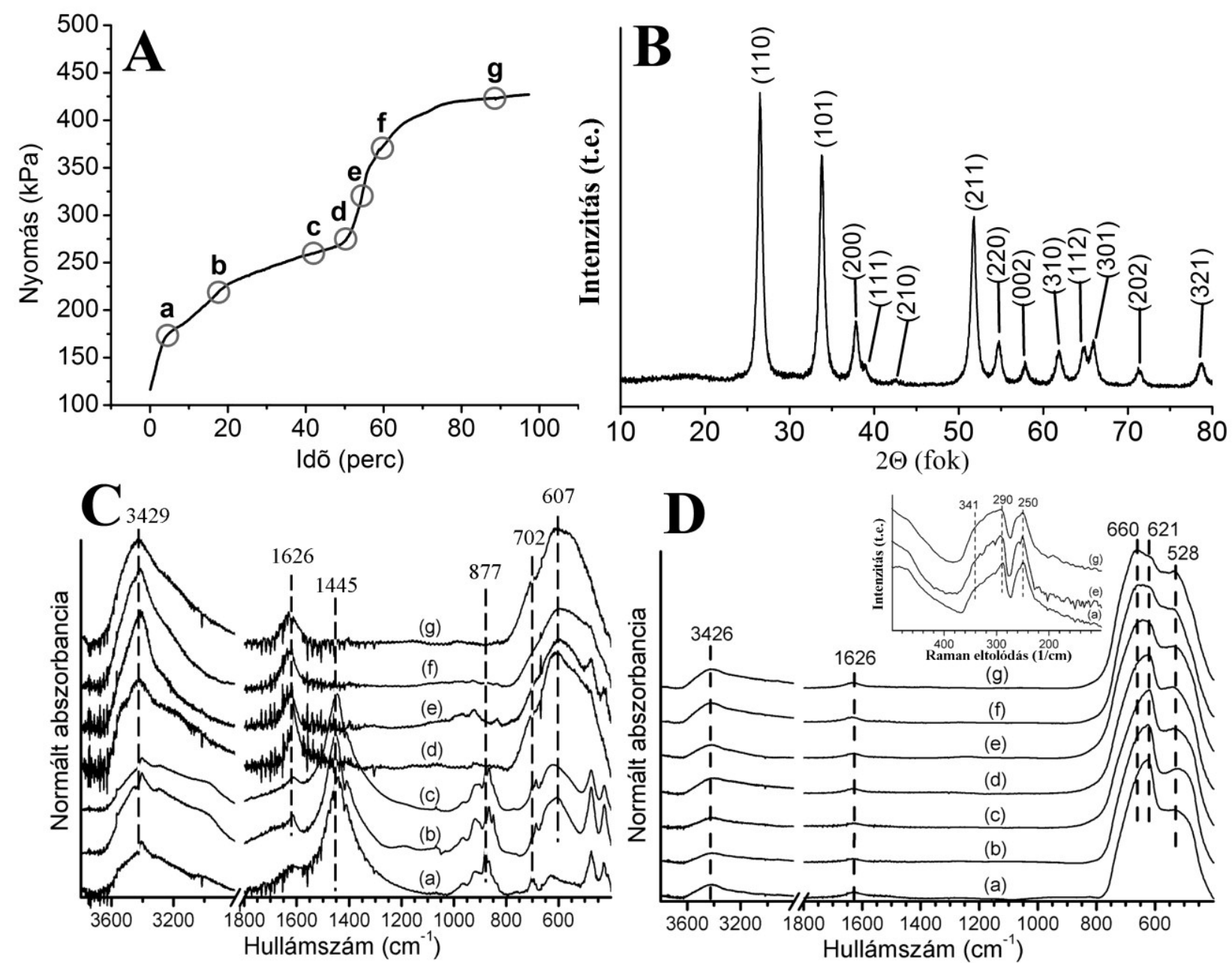

5.23. ábra: A: mintavételi pontok. B: a hőkezelt és mosott ,g” jelü minta röntgen diffraktogramja. C: az örlés után közvetlenül a mintákról felvett FT-IR spektrumok. D: a hőkezelt és mosott minták FT-IR és Raman spektrumai.

A minták mindegyikét hőkezeltük, majd desztillált vizes mosás után XRD vizsgálatnak vetettük alá. Ennek során megállapítottuk, hogy az $\mathrm{SnO}_{2}$ eltérö intenzitással, de minden egyes mintában jelen volt, így csak a „g” jelü minta röntgen diffraktorgramját mutatom be az 5.23./B ábrán. A diffraktogramon az összes reflexió a rutil csoportba tartozó, tetragonális kristályszerkezetủ $\mathrm{SnO}_{2}$-hoz rendelhető, cella paraméterei: $\mathrm{a}=4,737 \AA, \mathrm{c}=3,185 \AA^{\AA} .^{229} \mathrm{Nem}$ azonosítottunk semmilyen más Sn-O összetételü termékhez tartozó reflexiót.

Mivel a mosatlan mintákban nagy mennyiségben volt jelen a mátrixként és melléktermékként is kialakuló, intenzív reflexiókkal rendelkező $\mathrm{NaCl}$, így az XRD 
vizsgálatok nem voltak alkalmasak az esetleg kisebb mennyiségben a porkeverékben még jelenlevő anyagok kimutatására. Emiatt FT-IR és Raman vizsgálatnak vetettük alá mind a hét mintánkat közvetlenül az örlés (5.23./C ábra), valamint a teljes kezelés után (5.23./D ábra). Az őrlést követően az „a-c” mintákról felvett spektrumokon látható, 1445, 877 és $702 \mathrm{~cm}^{-1}$ hullámszámnál jelentkező elnyelések rendre a karbonátionhoz tartozó síkbeli aszimmetrikus, degenerált, illetve a síkra merőleges poláris rezgések. ${ }^{230} \mathrm{~A}, \mathrm{~d}$ ” mintától ezek intenzitása jelentősen csökken, majd teljesen eltünnek, amire a gyorsan növekvő nyomás ad magyarázatot: a $\mathrm{CO}_{2}$ az elbomló $\mathrm{Na}_{2} \mathrm{CO}_{3}$-ból származik. Ennek elnyeléseit $2300-2400 \mathrm{~cm}^{-1}$ közt a fenti IR spektrumokon nem jelöltük. Az 1622 és $3429 \mathrm{~cm}^{-1}$ hullámszámú elnyelési sávok az O-H kötések hajlító és nyújtó rezgéseiből erednek, míg a $607 \mathrm{~cm}^{-1}$ elnyelés az $\mathrm{Sn}(\mathrm{II}) \mathrm{O}$ jelenlétét mutatja. Ez utóbbi 3 rezgés a spektrumon a karbonátionnal ellentétben egyre intenzívebb jelet produkál: az $\mathrm{Sn}$ (II)O mennyiségének növekedése várható a reakció előrehaladtával, míg az O-H kötések egyre erősödő elnyelései a kristályvizes $\mathrm{SnCl}_{2}$-ból kilépő víz jelenlétével magyarázható. Ugyanezek az O-H rezgések a teljesen kezelt (kiégetett és mosott, majd szárított) mintákban már alig felfedezhetőek. Ezzel szemben a 660, 621 és $528 \mathrm{~cm}^{-1}$ hullámszámnál jelentkező csúcsok az Sn-O és Sn-O-Sn kötések rezgései, melyek jól kivehetőek mindegyik minta esetén. A Raman eredmények is az $\mathrm{SnO}_{2}$ jelenlétét bizonyítják: $470 \mathrm{~cm}^{-1}$-nél az $\mathrm{A}_{2 \mathrm{u}}, 250,290$ és $341 \mathrm{~cm}^{-1}$-nél az $\mathrm{E}_{\mathrm{u}}(1), \mathrm{E}_{\mathrm{u}}(2)$ és $\mathrm{Eu}(3)$ rezgési átmenetek sávjai láthatóak (5.23./D ábra). ${ }^{231} 232$

A termék elektronmikroszkópiás (TEM és SEM) vizsgálatával a részecskék méreteloszlását és aggregáltságát határoztuk meg (5.24. ábra). A legtöbb TEM felvételen a részecskék jól elkülönültek egymástól. Mint azt már a bevezetőben említettük, az átlagos átmérő 9 nm-nek adódott. Mivel az őrlés során $\mathrm{SnO}$ terméket kapunk, így az $\mathrm{SnO}_{2}$ a hőkezelés során alakul ki. Bár az $\mathrm{SnO}_{2}$ olvadáspontja $1600{ }^{\circ} \mathrm{C}$ feletti, a nanoméretü anyagokra jellemző a tömbi megfelelőjükhöz képest drasztikusan csökkenő olvadáspont. ${ }^{233}$ Az egyedi részecskék szintereződése már a nanorészecske olvadáspontja alatti hőmérsékleten is fokozatos méretnövekedést okozhat. Emiatt vizsgáltuk a hőkezelés után az egyes minták átlagos átmérójének változását, a hőmérsékletet $500-800{ }^{\circ} \mathrm{C}$ közt változtatva. Az eredményt az 5.24. ábrán mutatom be. A méreteloszlás hőmérsékletfüggésének vizsgálata során nem tapasztaltunk lényeges eltérést a különböző hőfokon kezelt minták átmérőeloszlásában. A részecskék átmérője egészen a $800{ }^{\circ} \mathrm{C}$-os hőkezelésig a 8,5-10,5 nm-es mérettartományban maradt. A legszűkebb méreteloszlást $500{ }^{\circ} \mathrm{C}$-on mértük, míg $800{ }^{\circ} \mathrm{C}$-on a részecskék átlagos átmérőjének szórása megnő, ami a szintereződés jelenségével magyarázható. 


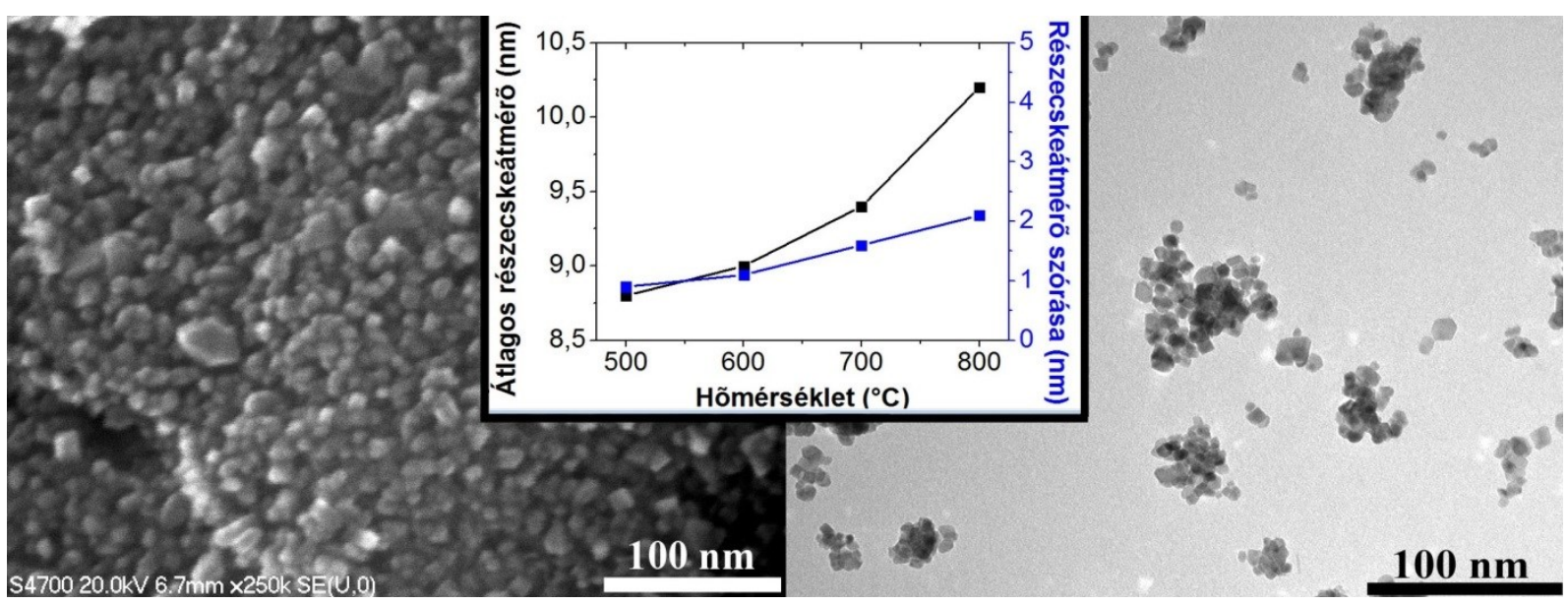

5.24. ábra: Jellemző SEM (balra) és TEM (jobbra) felvételek a hőkezelt $\mathrm{SnO}_{2}$ nanorészecskékről, valamint a TEM képek alapján meghatározott hőmérsékletfüggő átlagos részecskeátmérő (匹) és annak szórása $(\boldsymbol{\square})$.

\subsubsection{Nikkel-oxid nanorészecskék előállítása}

Mechanokémiai úton az $\mathrm{SnO}_{2}$ készítésével analóg karbonátos szintézissel $\mathrm{NiO}$

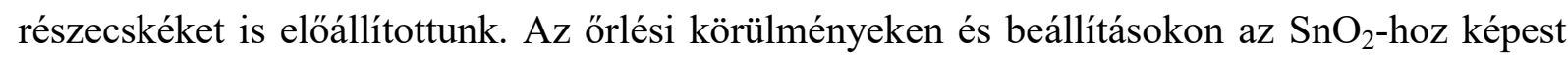
alapvetően nem változtattunk.

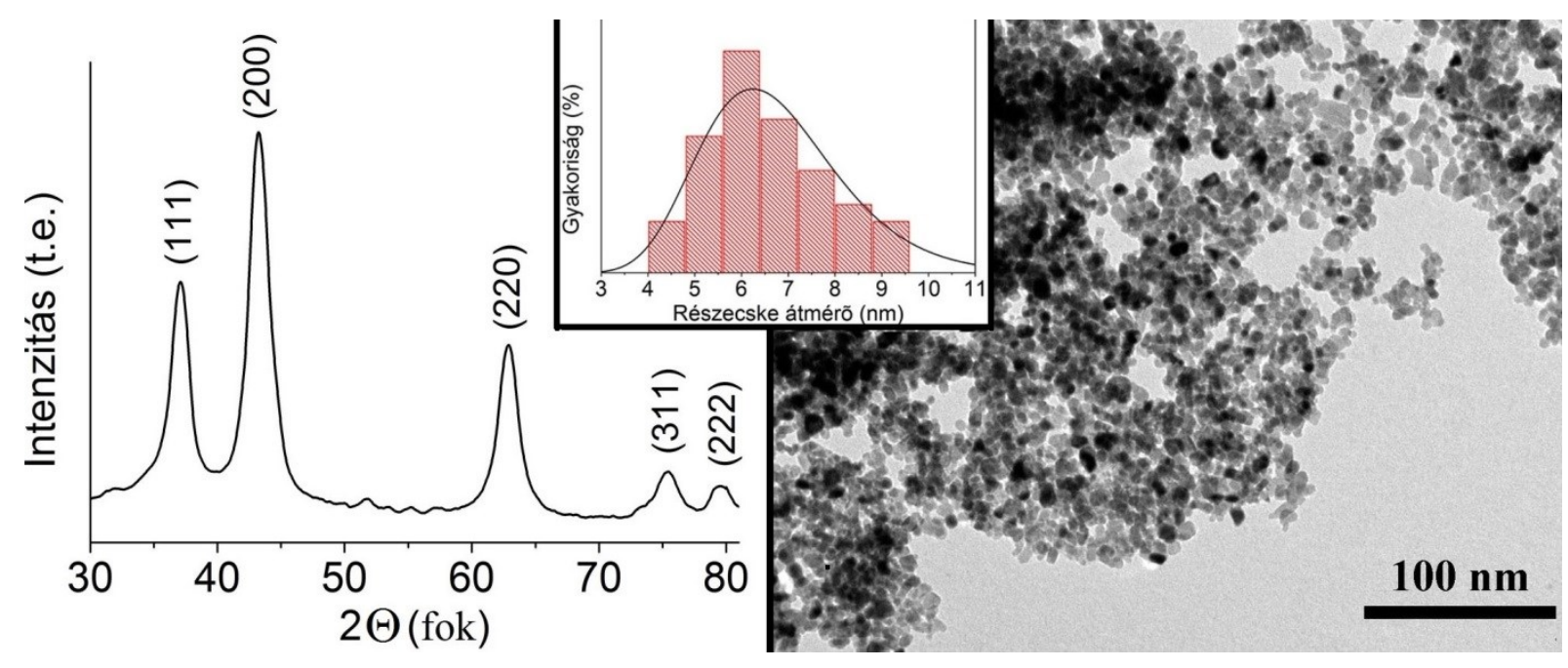

5.25. ábra: Az előállított $\mathrm{Ni}(\mathrm{II}) \mathrm{O}$ nanorészecskék röntgen diffraktogramja (balra), részecskeméret eloszlása (középen) és egy jellemző TEM felvétele (jobbra).

A röntgen diffraktogramon jelölt reflexiók mindegyike az oktaéderes szerkezetü $\mathrm{Ni}(\mathrm{II}) \mathrm{O}-\mathrm{hoz}$ tartozik (5.25. ábra). ${ }^{234}$ A csúcsok szélessége a részecskék kis méretével $(\sim 6 \mathrm{~nm})$ magyarázható. ${ }^{235} \mathrm{Az}$ egyes részecskék jól elkülönülnek egymástól, átmérőjük 4 és $10 \mathrm{~nm}$ közt változik, az átmérő szórása kicsi. 
Az előállított minta egy részét további vizsgálatokra a graz-i Karl-Franzens Egyetem Fizika tanszékére küldtük, ahol Karl Ettinger vezetésével a különböző méretű NiO részecskék mágneses tulajdonságait kutatják. ${ }^{236}$ Eredményeikben alapvető különbségekről számoltak be 10 nm-nél kisebb, a 40 nm és a 100 nm-nél nagyobb átmérőjű részecskék közöt. Azt általunk elöállított részecskéken a többihez képest nagyobb koercivitást (felmágnesezett ferromágnesek ellenállása egy külső demagnetizáló erőtérrel szemben) mértek.

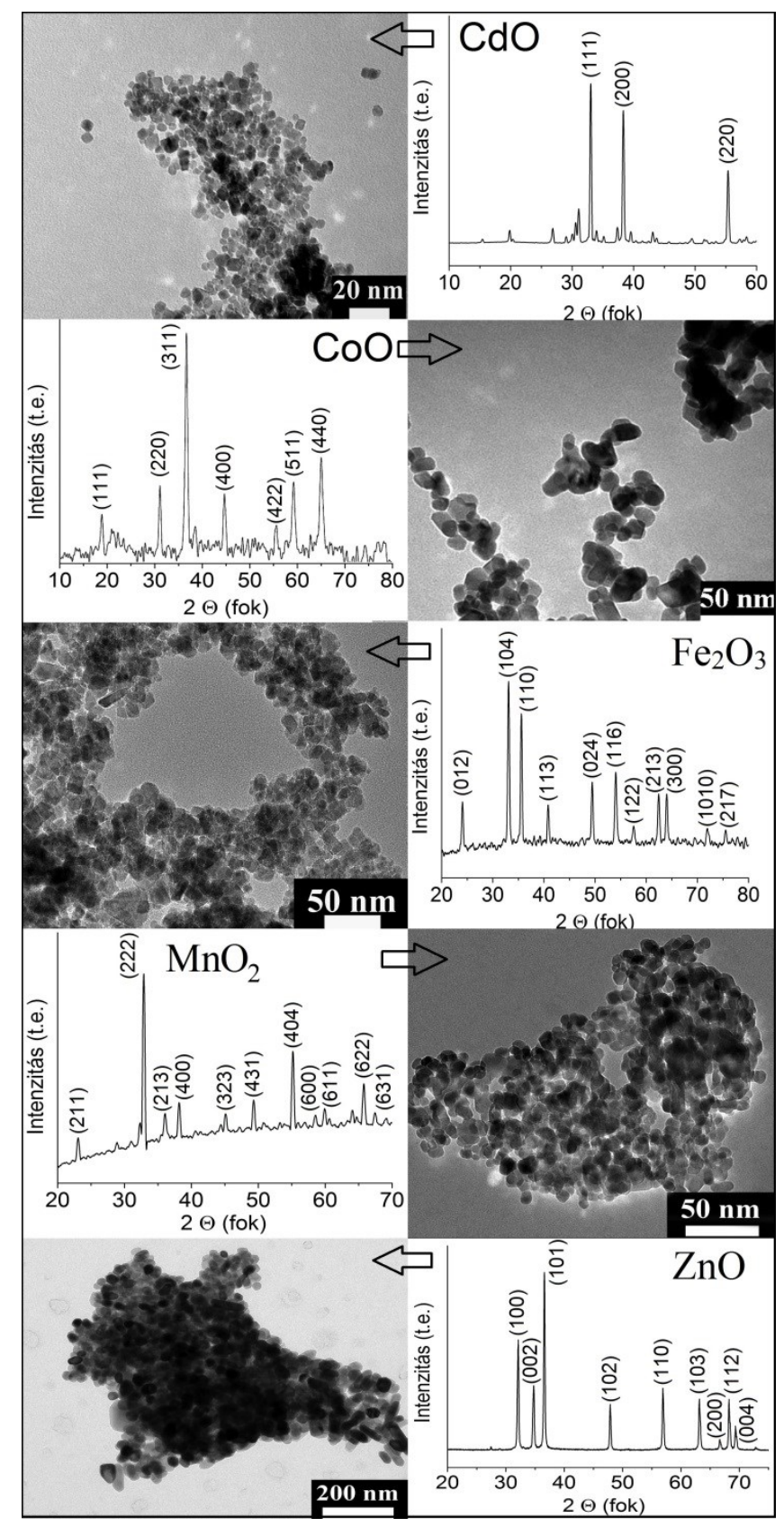

5.26. ábra: $\mathrm{Na}_{2} \mathrm{CO}_{3}$-tal előállított fém-oxid nanorészecskék jellemző TEM felvételei és röntgen diffraktogramjai. 
Összességében kijelenthetjük, hogy sikerült egy olyan eljárást kidogoznunk, mellyel többféle különböző nanokristályos fém-oxid részecske előállítható, illetve ami alkalmas lehet más összetételü termékek szintézisére hasonló mérettartományban. A későbbiekben olyan fém-oxid nanorészecskéket állítottunk elő sikeresen, melyeket más kutatócsoportok vizsgáltak tovább. Ezekre példa a mangán-oxid, ${ }^{237}$ valamint a kadmium-oxid ${ }^{238,}{ }^{239}$ nanorészecskék toxikus hatásának vizsgálata. ${ }^{240} \mathrm{Az}$ ezekről, valamint más felhasználásokhoz általunk mechanokémiai úton előállított $\mathrm{ZnO}, \mathrm{CoO}$ és $\mathrm{Fe}_{2} \mathrm{O}_{3}$ részecskékről készült TEM felvételeket és röntgen diffraktogramokat az 5.26. ábrán mutatom be.

\subsubsection{Nikkel-ferrit nanorészecskék előállítása}

A fém-oxid nanorészecskék előállítási tapasztalatai alapján megkíséreltük a nikkel-ferrit egy lépésben történő mechanokémiai előállítását is. A ferritek mechanokémiai szintézise az irodalom szerint általában fém-oxid prekurzorokból történik. ${ }^{241,}{ }^{242}$ Ezzel szemben mi az alkotóelemek fémsóinak felhasználásával végeztük el a szintézist azért, hogy a termékünk minél kisebb átmérővel és lehetőleg monodiszperz méreteloszlással bírjon. Kiindulási anyagként $\mathrm{NiCl}_{2}$-t és $\mathrm{FeCl}_{3}$-t használtunk $\mathrm{Na}_{2} \mathrm{CO}_{3}$ reakciópartner mellett. Ez azért is hasznos volt, mert így képesek voltunk a szintézis idejét gyorsan optimalizálni. Az őrlést az $\mathrm{SnO}_{2}$ esetében már bemutatott módon, a leolvasott nyomás alapján az elöre meghatározott 90 \%-os konverzió értékig folytattuk. A két fémsó magas víztartalma miatt jelentős kitapadást tapasztaltunk. A $\mathrm{NiFe}_{2} \mathrm{O}_{4}$ részecskék átlagos átméröje 8,5 nm volt. A NiO-hoz hasonlóan a partikulumok itt is jól elkülönülnek (5.27. ábra).

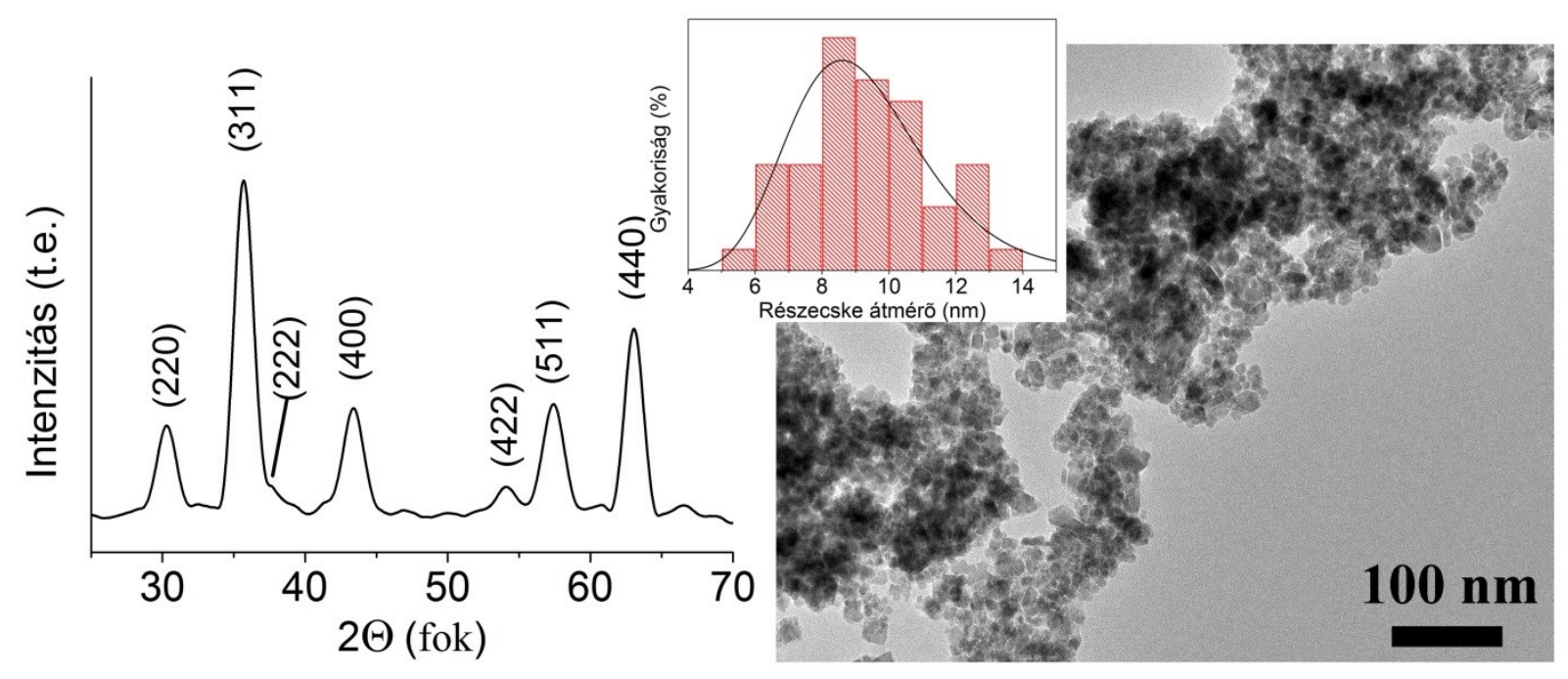

5.27. ábra: Az elöállított $\mathrm{NiFe}_{2} \mathrm{O}_{4}$ nanorészecskék röntgen diffraktogramja (balra), részecskeméret eloszlása (középen), és egy jellemző TEM felvétele (jobbra). 
Az elöállított részecskék röntgen diffraktogramján látható reflexiók mindegyike a köbös kristályrácsú $\mathrm{NiFe}_{2} \mathrm{O}_{4}$-hez tartozik. A NiO és $\mathrm{Fe}_{2} \mathrm{O}_{3}$ kristályszerkezetéhez tartozó reflexiókat nem detektáltunk. Ebből arra következtethetünk, hogy a prekurzorokból keletkező összes NiO és $\mathrm{Fe}_{2} \mathrm{O}_{3}$ továbbalakult $\mathrm{NiFe}_{2} \mathrm{O}_{4}$-té. Így mindössze 2 órára volt szükség a szintézishez, míg hasonló örlési körülmények közt, de közvetlenül fém-oxidokból kiindulva az 14-16 órán át is tarthat. ${ }^{242}$ A gyorsulás feltételezhetően az őrlés közben újonnan kialakuló, nanoméretü fémoxid intermedierekkel magyarázható, melyek nagy felületük révén gyorsan alakulhatnak tovább. Ugyanakkor nem zárható ki teljesen az egylépéses, azaz a különálló oxidszemcséket „átugró” reakcióút sem, de ennek bizonyítása vagy cáfolata túlmutatott a jelen disszertáció keretein. 


\subsection{Mechanokémiailag előidézett fázisátalakulások vizsgálatai}

Érdekes kérdés, hogy a szemcseméret változtatáson és a mechanokémiai reakciók indukálásán túl a bolygó golyósmalom alkalmas-e fázisátalakítások, átkristályosodások, morfológiai változások előidézésére is. Ezirányú vizsgálatainkat titán-oxid nanoszerkezetekkel végeztük el. Szálas szerkezetü trititanát nanoszálak őrlésével a szén nanocsövekhez hasonlóan elvégeztük az őrlés paramétereinek mélyrehatóbb vizsgálatát. Ez a korábbi kísérletektől abban tért el, hogy az őrlési térkép egy kisebb energiájú területére koncentráltunk, ami a TiONW szén nanocsövekhez képest „gyengébb” szerkezetével (pl. kisebb Young-modulus) magyarázható. Így újabb információhoz jutottunk a következő szempontokból: 1) korábbi megállapításainkat egy másik energiatartományban is igazolhattuk; 2) vizsgálhattuk a csöves, majd szálas trititanát struktúra kialakulását; 3 ) bővítettük a mechanokémiával előállítható szerkezetek listáját, ami a módszer alkalmazhatósága mellett annak szabályozhatóságát is bizonyítja.

\subsubsection{Titán-dioxid nanorészecskék előállítása mechanokémiával}

A nanoméretű fém-oxid részecskék már korábban bemutatott előállítási módszerét alkalmaztuk titán-dioxid szintézisére is $\mathrm{TiCl}_{4}$-ból kiindulva. $\mathrm{Az}$ irodalomban fellelhető mechanokémiai $\mathrm{TiO}_{2}$ szintézisekhez jellemzően $\mathrm{TiOSO}_{4}-\mathrm{t},{ }^{243}, 244$ vagy $\mathrm{TiCl}_{4}$ mellett $\mathrm{NH}_{4} \mathrm{HCO}_{3}$ használnak ${ }^{245,} 246$ és a terméket 250-700 ${ }^{\circ} \mathrm{C}$ között utólag hőkezelik. A $\mathrm{TiO}_{2}$ fázisátalakulásokkal foglalkozó mechanokémiai cikkek kiindulási anyagként általában $\mathrm{TiO}_{2}-\mathrm{t}$

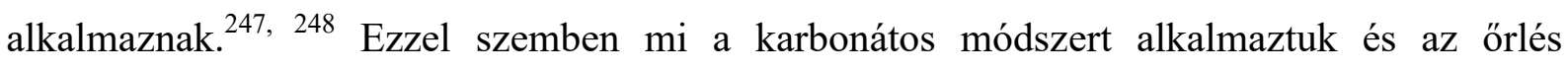
energiáját használtuk a különböző kristályszerkezetü $\mathrm{TiO}_{2}$ kialakításához, emellett pedig GTM egység segítségével követtük a reakció kinetikáját. A korábbi szintéziseknél tapasztaltakhoz hasonlóan most is $\sim 90 \%$-os volt a reaktánsok konverziója. A közel 10 órás őrlés alatt rögzített nyomás-idő görbét az 5.28. ábrán mutatom be. 


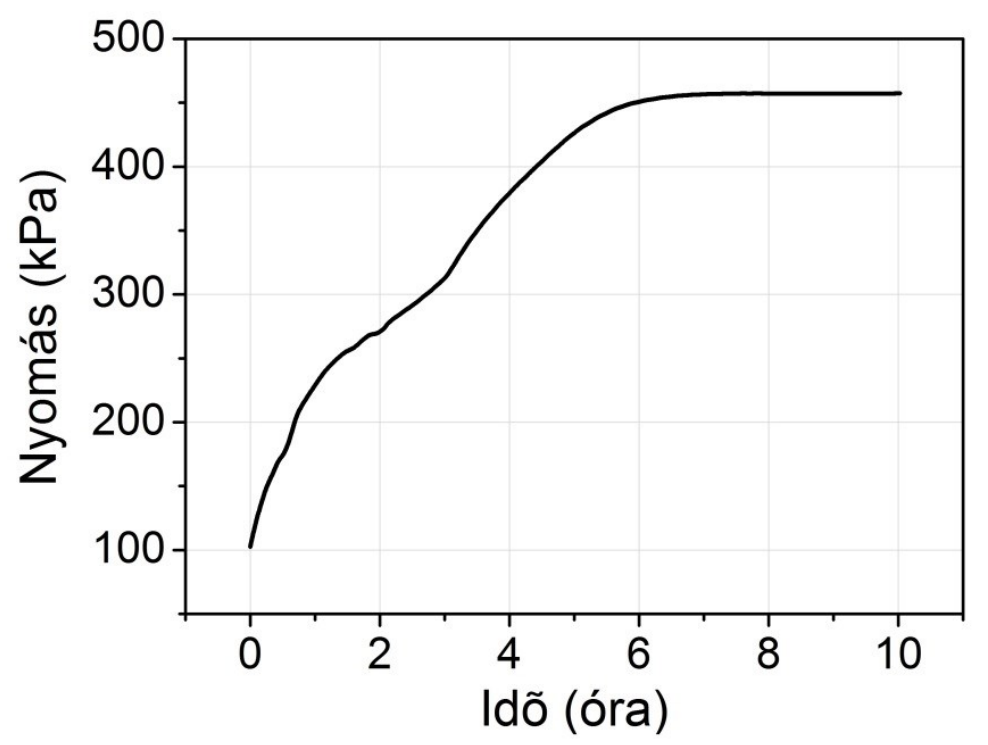

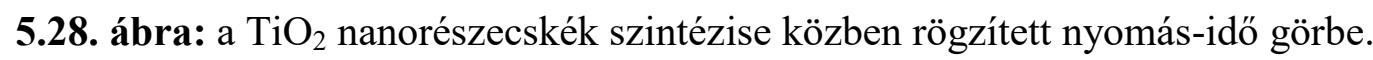

Az 5.2 fejezetben értelmezett nyomásemelkedés-anomáliát itt is felfedezhetjük, bár az $\mathrm{SnO}_{2}$ elöállításához képest kevésbé különülnek el a nyomáslépcsők. Ez a kisebb reakciósebességgel és a rendszerben lévő lényegesen kevesebb vízzel magyarázható. Az őrlés elejéről (1 óra), közepéről (5 óra) és végéről (10 óra) vett minták desztillált vizes mosása után felvettük azok röntgen diffraktogramjait, melyeket az 5.29. ábrán mutatok be.

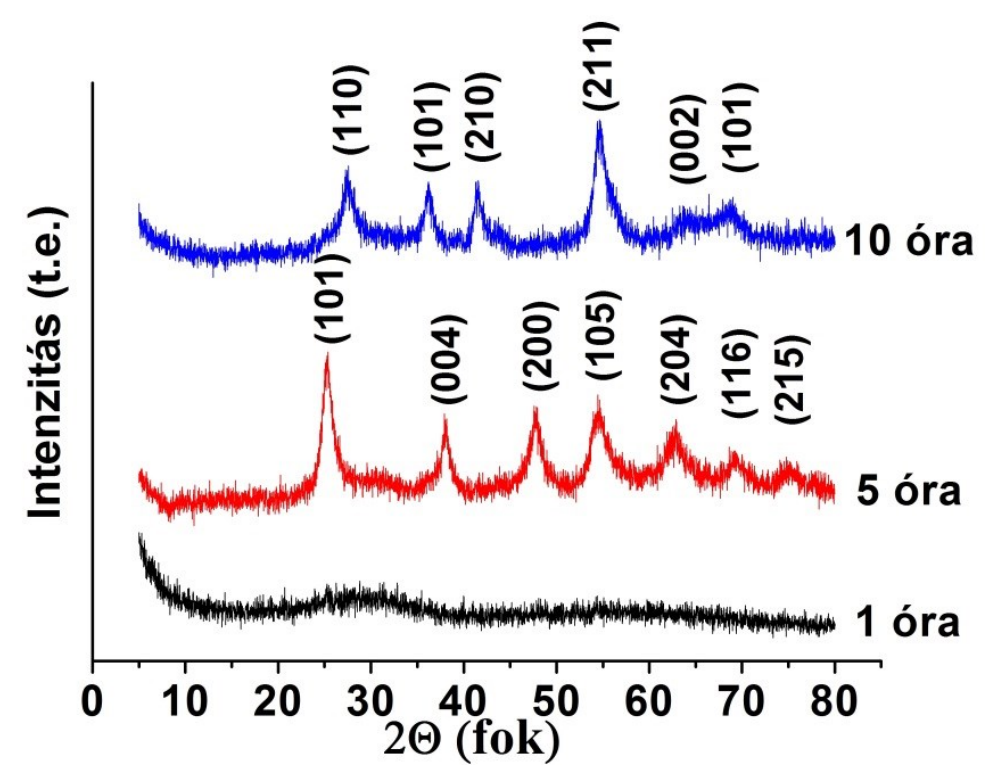

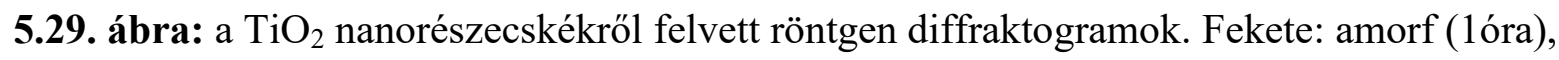
piros: anatáz (5 óra), kék: rutil (10 óra) kristályszerkezetü $\mathrm{TiO}_{2}$.

Az első órában még nem találtunk kristályos $\mathrm{TiO}_{2}$-ra jellemző reflexiókat. Ez adódhat a termék amorf mivoltából vagy alacsony mennyiségéből is, hiszen a nyomás-idő görbe szerint 
a konverzió 1 óra után még csak 20\%. 5 óra elteltével már a tetragonális anatázra, a 10 órás őrleményben pedig a szintén tetragonális kristályszerkezetü rutilra jellemző reflexiókat mutattuk ki. A két időpont között polimorf formában mindkét szerkezet felismerhető (5.30. ábra). Bár az irodalomban elég eltérő adatokat találhatunk az anatáz $\rightarrow$ rutil átkristályosodási hőmérsékletről, az egyértelmű, hogy az átalakuláshoz $400-600{ }^{\circ} \mathrm{C}$ vagy ezzel egyenértékủ energia szükséges. ${ }^{249} 800{ }^{\circ} \mathrm{C}$ fellett a polimorf állapotot a tiszta rutil fázis váltja fel. ${ }^{250}$ Dorian és társai egy átfogó tanulmányban foglalkoznak az anatáz $\rightarrow$ rutil fázisátalakulással. Írásukban kitérnek arra, hogy az átalakuláshoz szükséges hőmérsékletet a nyomás alapvetően meghatározza. ${ }^{251}$ Emellett az egyedi részecskék mérete vagy a dópolt szerkezet is jelentősen befolyásolja ezt az értéket. ${ }^{252,253}$ Jelen esetben az átkristályosodáshoz a nagy energiájú mechanokémiai kezelés szolgáltatta a szükséges energiát.

A folyamat részletesebb feltérképezése érdekében újabb mintasort készítettünk, amelyben már óránként vettük fel a termék röntgen diffraktogramját. Természetesen az egyes minták mindig újabb őrlemény összeállítását igényelték. A jobb átláthatóság kedvéért az 5.30. ábrán csak az egymástól eltérő diffraktogramokat mutatom be. (Az idő-nyomás görbén jelöltem a mintavételi pontokat is, így a két adatsort közös időskálával láttam el.)

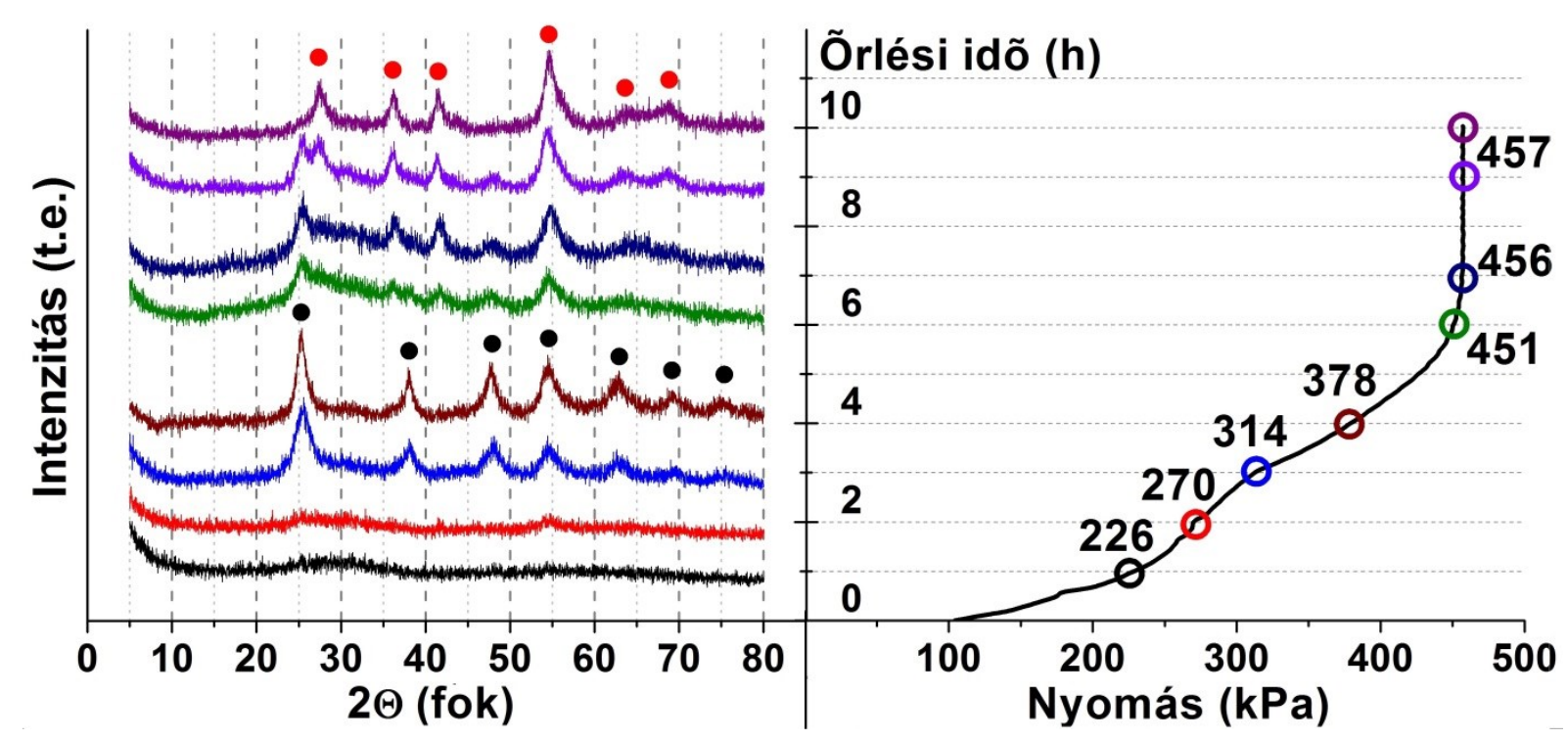

5.30. ábra: a mechanokémiai $\mathrm{TiO}_{2}$ szintézis különböző időpontjaiban vett mintáinak röntgen diffraktogramjai (balra) és az idő-nyomás görbe (jobbra) közös időskálán bemutatva. A • a rutil, a • az anatázra jellemző reflexiókat, a színes körök a mintavételi pontokat jelölik feltüntetve az aktuális nyomásértékeket kPa-ban. 
$\mathrm{Az}$ egyes fázisok időfüggő átalakulása követhető az 5.30. ábrán. 3 óra elteltével, 65 \%-os konverziós értéknél már megjelenik az anatáz kristályszerkezet (cellaparaméterek $\mathrm{a}=3,7845 \AA ; \mathrm{c}=9,5143 \AA$ ), melynek reflexiói a röntgen diffraktogramokon egészen a kilencedik óráig azonosíthatóak. A rutilra (cellaparaméterek: $\mathrm{a}=4,5937 \AA ; \mathrm{c}=2,9587 \AA$ ) jellemző reflexiók a hat órán át őrölt mintában jelennek meg először. A nyomásalapú konverziószámító egyenletünk szerint a prekurzoroknak ekkorra már $93 \%$-a átalakult $\mathrm{TiO}_{2}$-dá. A polimorf állapot, azaz a két kristálymódosulat közös jelenléte egészen a 9. óráig fennáll, majd 10 órányi őrlés után már csak a rutilt azonosíthatjuk be a tisztított mintában.

A 10 órás mintáról TEM felvételt készítettünk, melynek segítségével meghatároztuk a részecskék méreteloszlását. A karbonátos fém-oxid nanorészecske szintézismódszer korábbi eredményeivel összhangban ezúttal is közel monodiszperz terméket kaptunk. A részecskék átlagos átmérője 7,2 nm. A terméken a TEM felvételek készítése közben elektrondiffrakciós mérést is végeztünk (5.31. ábra).

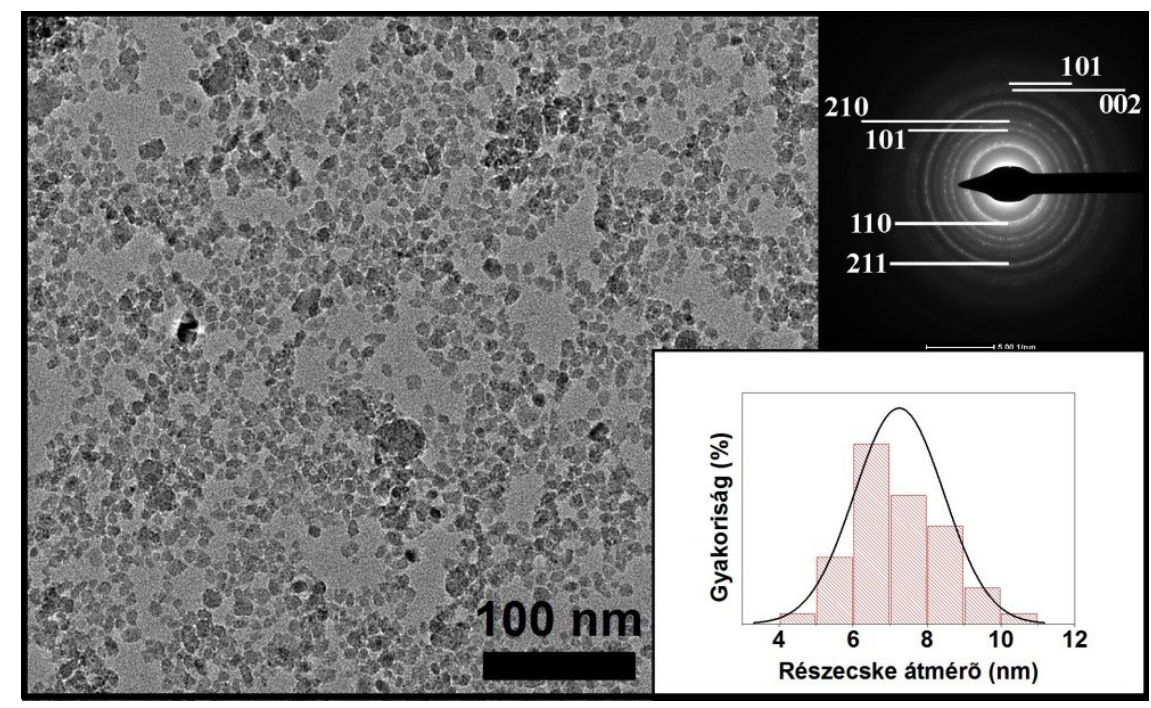

5.31. ábra: a malomban előállított $\mathrm{TiO}_{2}$ nanorészecskék TEM képe és rutil szerkezetre jellemző ED felvétele, valamint a részecskék méret eloszlás hisztogramja.

Összefoglalva elmondható, hogy mechanokémiai úton nem csak monodiszperz $\mathrm{TiO}_{2}$ nanorészecskék állíthatók elő, hanem ugyanabban a szintézislépésben elvégezhető az anatáz $\rightarrow$ rutil fázisátalakítás is. A mechanokémiai fázisváltás előnyös tulajdonsága, hogy a rutil kialakítása a reakcióelegy hőmérsékletének jelentős emelése nélkül, kvázi szobahőmérsékleten történik meg. 


\subsubsection{Trititanát nanoszálak szerkezetváltozása őrlés hatására}

Az irodalomban elsőként vizsgáltuk a trititanát nanoszálak őrlési sajátosságait. Előkísérleteinkből kiderült, hogy a TiONW-k kis energiájú behatásra is számottevő roncsolódást szenvednek, így a megfelelő eszköz az őrlések kivitelezésére a $\mathrm{Si}_{3} \mathrm{~N}_{4}$ dob volt. Kisebb sürűsége miatt ezt használva azonos paraméterek esetén a beütési energia kevesebb, mint a fele a rozsdamentes acél örlődobhoz képest. Az őrlés idejét 15 percben kellett korlátozni, mivel a magas $E_{\text {cum }}$ hamar a szálak teljes roncsolódásához vezetett. Végül úgy állítottuk be az örlési paramétereket, hogy az $E_{\text {cum }}$ értéke 33-4130 J/g (TIONW) közt változzon (fordulatszám $=100-500 \mathrm{rpm}$ ). Ezeket a mintákat B-F-ig jelöltük, az „A” jelü minta pedig a kezeletlen TiONW-t jelöli, aminek jellemző hossza 1-3 $\mu$ m, átmérője 45-90 nm volt.

A mintasort először TEM vizsgálatnak vetettük alá (5.32. ábra). Az ábrán fehér nyíllal jelöltünk egy golyóbecsapódás miatt roncsolódott szálrészletet. Az $E_{c u m}$ értéke ezen a fordulatszámon $(100 \mathrm{rpm})$ mindössze $33 \mathrm{~J} / \mathrm{g}$ volt. A szálhossz és az átmérő rendre 100-680 nm-re, valamint 18-50 nm-re csökkentek. Ezen az energiaszinten tehát a nanoszálak előnyösen a hosszuk mentén hasadtak kisebb szálakra, azaz a várakozásnak megfelelően törtek. Magasabb fordulatszám mellett $\left(E_{\text {cum }}=264 \mathrm{~J} / \mathrm{g}\right)$ a szálhossz $70-500 \mathrm{~nm}$, míg az átmérő 18-30 nm közé esik. A szálas szerkezet még mindig felismerhető, ugyanakkor a mért hosszúsági adatok alsó határa már a TiONT-re jellemző értéket mutatja. Jelentős változást $892 \mathrm{~J} / \mathrm{g}$ összes befektetett energia mellett figyelhetünk meg. A TEM felvételen látható fragmentek már nem egyszerüen az összetöredezett szálak építőelemei, hanem a nanocsövekre jellemző geometriával rendelkeznek, átlagos hosszuk 40-80 nm. A csöves struktúra jól látható az 5.32./D-1 ábrán (oldalnézetben láthatóak a falvastagságból eredő kontrasztos szélek), a D-2 képen pedig a kép síkjára merölegesen álló csövek keresztmetszete is kivehető. Az őrlési energiát tovább növelve 2114, illetve $4130 \mathrm{~J} / \mathrm{g} E_{\text {cum }}$ mellett már a csőszerü szerkezet is eltünik. Ekkor a rendszert néhányszor $10 \mathrm{~nm}$ átmérőjü szemcsék agglomerátumai alkotják. 


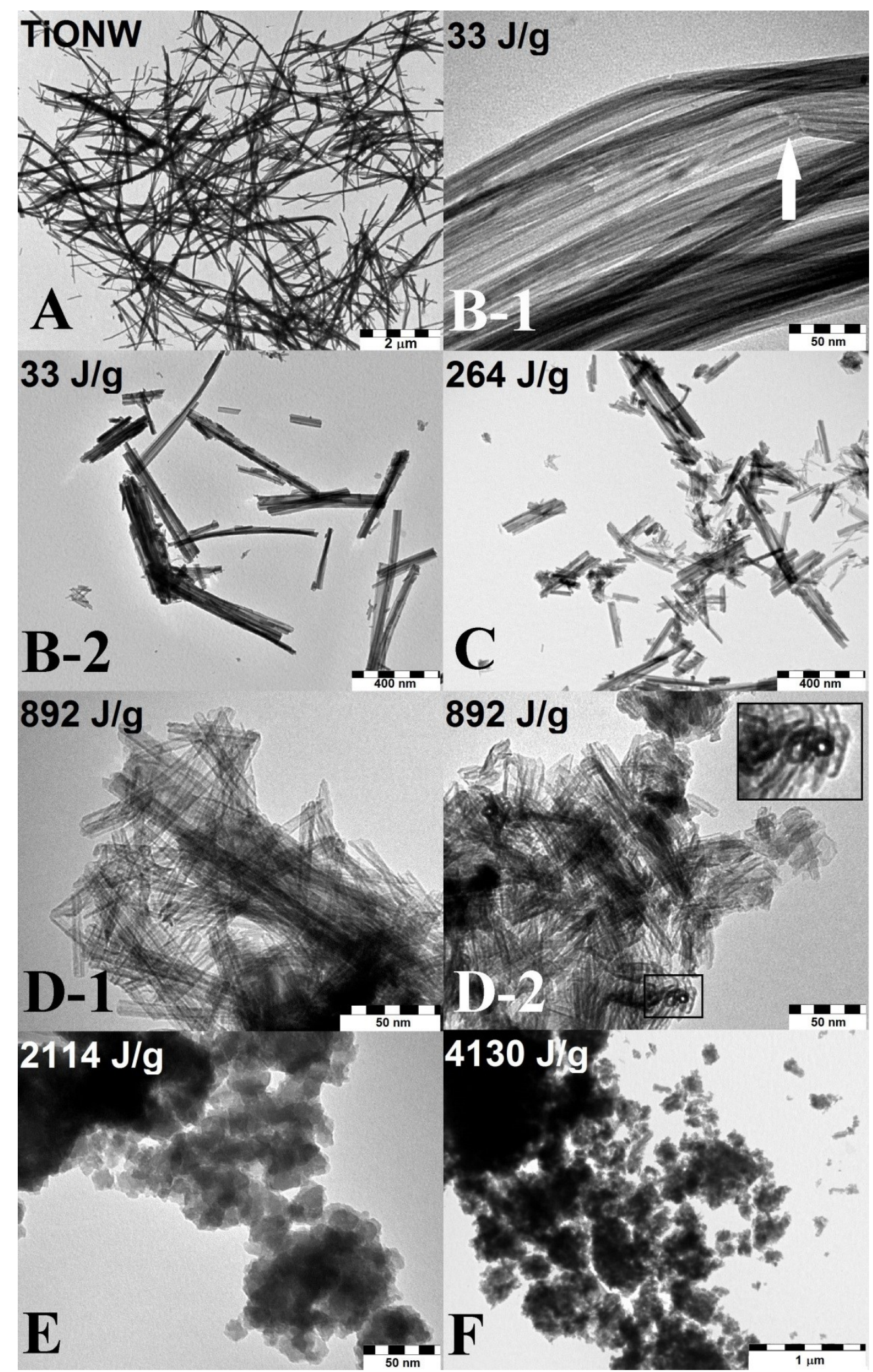

5.32. ábra: őrléssel kezelt TiONW minták TEM felvételei. A jobb felső képen a fehér nyíl egy becsapódás nyomát mutatja, míg alulról a második jobb képen a minta csöves morfológiáját emeltük ki. 
A különböző titanát szerkezetek fajlagos felülete nagyon különböző, ami lehetővé teszi azok még pontosabb azonosítását. ${ }^{254}$ A TEM felvételeken alapuló elemzést ezért az 5.33. ábrán bemutatott nitrogénadszorpciós vizsgálattal egészítettük ki. $\mathrm{A} \mathrm{TiO}_{2}$ részecskékből kiinduló TiONT és TiONW szintézis során a fajlagos felület a következők szerint változik: a $\mathrm{TiO}_{2}$ nanorészecskék méretüktől függően $\sim 50 \mathrm{~m}^{2} / \mathrm{g}$ felülettel rendelkeznek, ami a nanocsövek kialakulása után $200 \mathrm{~m}^{2} / \mathrm{g}$ felé emelkedik, míg a titanát nanoszálak esetében ez újra $100 \mathrm{~m}^{2} / \mathrm{g}$ alá esik. ${ }^{255,256}$

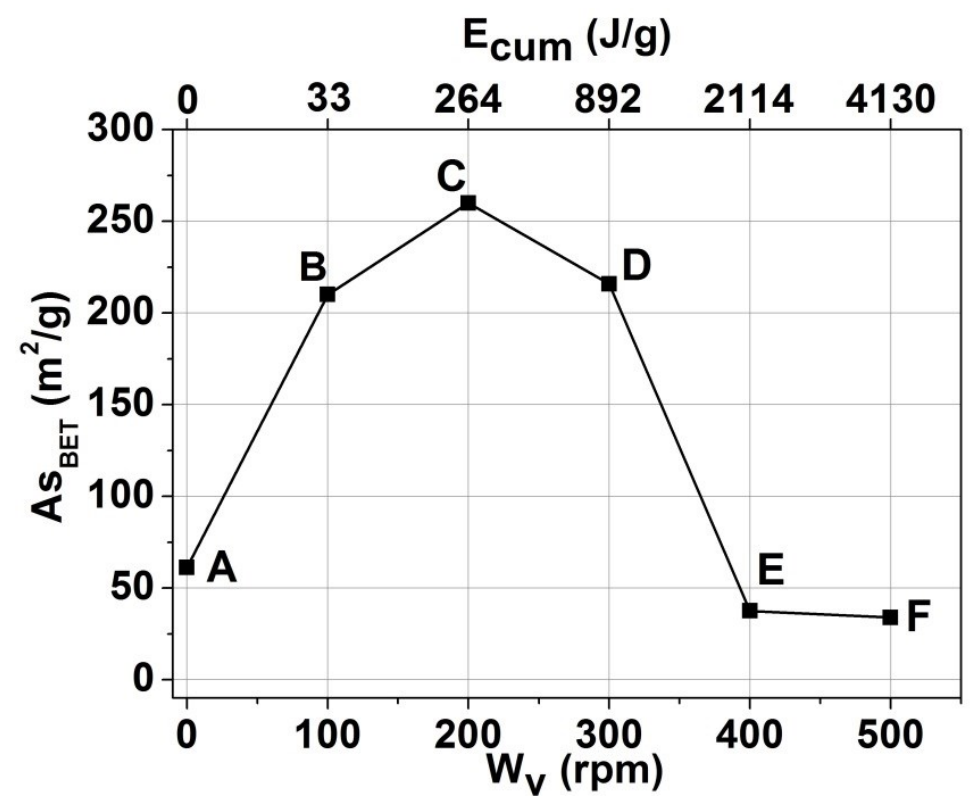

5.33. ábra: kezeletlen (A) és különböző energiával (B-F: $E_{c u m}=33-4130 \mathrm{~J} / \mathrm{g}$ ) őrölt minták fajlagos felületének alakulása a fordulatszám függvényében.

Esetünkben a korábban A-F-ig jelölt hat minta mérési eredményeit az 5.33. ábra szemlélteti. A kiindulási anyag - tehát a kezeletlen TiONW - fajlagos felülete $57 \mathrm{~m}^{2} / \mathrm{g}$ volt. Ez az érték a „B” és „C" minták esetén 207, majd $255 \mathrm{~m}^{2} /$ g-ra emelkedik. Ez azzal magyarázható, hogy a nanoszálak a hidrotermális szintézis során a nanocsövek rendeződéséből jönnek létre, ami együtt jár azok tömörödésével, majd az üreges szerkezet fokozatos felemésztődésével. Mivel a TiONT fajlagos felületéhez hozzájárul a csövek belseje és azok felülete is, így miután azok egyre szorosabban kapcsolódnak egymáshoz, a nitrogénmolekulák számára elérhető helyek száma drasztikusan lecsökken. A mi esetünkben ez pont fordítva játszódik le. Igaz, még nem alakult át az összes anyagunk nanocsővé, ám a szálak fellazulása és töredezése egyre nagyobb szabad felületet biztosít a $\mathrm{N}_{2}$ molekulák számára. A „D” mintánál az As $\mathrm{BSET}_{\mathrm{BE}}$ értéke kissé lecsökken $210 \mathrm{~m}^{2} / \mathrm{g}-\mathrm{ra}$. A TEM felvételeken itt találtuk a legtöbb már egyedi csövekké töredezett szerkezeti elemet, de ezen az 
energiaszinten már a keletkező nanorészecskék agglomerációja megmagyarázza a fajlagos felület csökkenését. Az $E_{\text {cum }}$ további növelésével, („E” és „F” jelü minták) összeroskad a nanocsövek szerkezete, és a 10-30 nm átméröjü partikulumok fajlagos felülete $40 \mathrm{~m}^{2} / \mathrm{g}$ alá esik. A porozitással nem rendelkező egyedi részecskék agglomerációja, a már korábban bemutatott szintereződés jelensége által (2.7 fejezet), a felület további csökkenését okozza. Az egyes fázisok és fázisátalakulások követéséhez végzett XRD mérések eredményeit az 5.34. ábrán mutatom be.

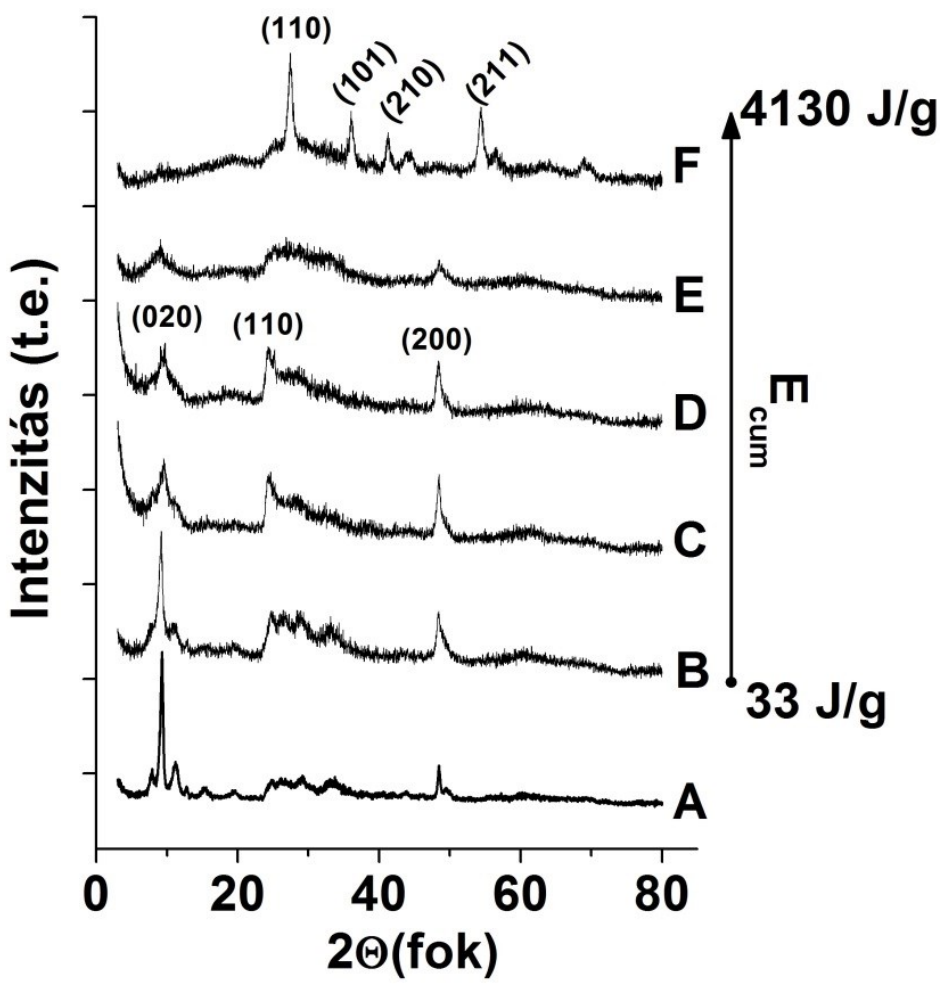

5.34. ábra: Kezeletlen (A) és különböző energiákon (B-F: $E_{c u m}=33-4130 \mathrm{~J} / \mathrm{g}$ ) örölt minták röntgen diffrakciós vizsgálatának eredményei.

Az „A” jelü mintáról felvett diffraktogramon beazonosíthatók a $2 \Theta 9,6^{\circ}$, valamint a $23,6^{\circ}$ és 48,6 ${ }^{\circ}$-nál a TiONW és TiONT-hez tartozó karakterisztikus trititanát reflexiók. ${ }^{250}$ Ezek a megőrölt TiONW-k közül egészen a „D” mintáig megjelennek, ami jól illik a TEM vizsgálatból kapott eredményekhez, miszerint addig fedezhető fel a nanocsövekre jellemző szerkezet. Összességében kijelenthetjük, hogy az $E_{\text {cum }}=892 \mathrm{~J} / \mathrm{g}$ volt szükséges a nanoszálak csövekké tördeléséhez. A TEM és $\mathrm{N}_{2}$ adszorpciós mérések alapján számottevő különbséget nem fedeztünk fel az „E” és „F” minták közt. Ennek ellenére diffraktogramjaik lényeges eltérést mutatnak: a $2114 \mathrm{~J} / \mathrm{g}$ energiával megőrölt mintákban izotróp részecskéket találunk. Mind a szálakhoz, mind a csövekhez tartozó reflexiók elmosódnak. Az „F” jelzésü 
őrleményben ezzel szemben újabb reflexiók jelennek meg $2 \Theta 27,5^{\circ}, 36,2^{\circ}, 41,3^{\circ}$ és $54,3^{\circ}$-nál, melyeket korábban már a rutil kristályszerkezetü $\mathrm{TiO}_{2}$-dal azonosítottunk (5.30. ábra).

Bizonyítottuk tehát, hogy jól szabályozott mechanikai hatásra a trititanát nanoszálakból nanocsövek, majd nanorészecskék állíthatóak elő. Az $E_{\text {cum }}<1 \mathrm{~kJ} / \mathrm{g}$ örlések eredményeként a nanoszálak csak részben töredeznek, hosszirányban viszont egyre fokozottabban hasadnak kisebb összetevőkre. Az „E” minta már főleg amorf szerkezetű $\mathrm{TiO}_{2}$-t tartalmaz, ami az őrlési idő előrehaladtával, azaz az $E_{\text {cum }}$ növelésével rutil kristályszerkezetűvé alakul át. Hasonló trititanát nanoszál $\rightarrow$ rutil szemcse átalakulási folyamatot találhatunk az irodalomban, ám azt oldatban, savas környezetben vittek véghez. ${ }^{257}$ Schuerer és társainak az átalakítás közben egyáltalán nem sikerült titanát nanocsöveket észlelniük.

Munkánk legérdekesebb eredménye a köztes $E_{\text {cum }}$ értékeknél tapasztalható trititanát nanocső megjelenés. Az irodalomban nagyon sok példa található trititanát nanocsövek előállítására a legkülönbözőbb módon (hidrotermális ${ }^{258}$, szol-gél ${ }^{259}$, lepárlás ${ }^{260}$, „elektrospinning”261), és a trititanátok általános egymásba alakíthatósága is ismert volt. ${ }^{262}$ Ennek ellenére nanoszálakból nanocsövet korábban még senkinek sem sikerült készítenie, ami valószínűleg a nanoszálak $\sim 20 \mathrm{~kJ} / \mathrm{mol}$-al kisebb szabadenergiájának köszönhető. Esetünkben erre azért nyílt lehetőség, mert a golyók által átadott energia hatására a nanoszálakból delaminálódó egyedi trititanát lapoknak a rendszer gyors lokális befagyása miatt nincsen lehetőségük újra a nanoszálhoz tapadni, így a szabad lapnál termodinamikailag még mindig kedvezőbb állapotot, a nanocsővé feltekeredést választják.

Összefoglalva elmondható, hogy az irodalomban elsőként bizonyítottuk kísérletileg a trititanát nanoszál fázis átalakíthatóságát trititanát nanocsővé. Ez egy nem-egyensúlyi átalakulás, amit a bolygó golyósmalomban uralkodó extrém reakciókörülmények tesznek lehetővé. A módszer más anyagokra is kiterjeszthető lehet, így ez a munka is bővíti a mechanokémia nanotechnológiai alkalmazhatóságát. 


\section{6 Összefoglalás}

Doktori munkám során mechanokémiával előállítható nanoszerkezeteket vizsgáltam abból a célból, hogy növeljem az ilyen úton szintetizálható nanoméretű anyagok számát. Ennek során nem csak az előállított nanoanyagok tulajdonságait, hanem a mechanokémiai reakciók kinetikáját és az őrléssel átalakított mechanikai energia számolására alkalmas modellt is vizsgáltam. A disszertációmban bemutatott eredményeket röviden az alábbiakban foglalom össze.

Szén nanocsövek mechanikai kezelésével vizsgáltuk a Burgio-Rojac őrlési energia számítására alkalmas modellt. Először statisztikai modell segítségével, majd kísérleti úton, megőrölt szén nanocsövek hosszának mérésével támasztottuk alá a modell helyességét. Megfigyeltük emellett az örlés paramétereinek hatását a nanocsövek rövidülésére. Kimutattuk, hogy a fordulatszám, az őrlési idő valamint az őrlőgolyók méretének és számának változtatása eltérő mértékben befolyásolja az átlagos csőhossz változását. Emiatt az egyes paraméterek nem feltétlenül helyettesíthetőek egymással.

Raman mérésekkel kimutattuk, hogy megfelelően beállított beütési és kumulatív energiával a szén nanocsövek roncsolása jól szabályozható. Míg előbbivel a hibahelyek száma vagy a csövek törése szabályozható, addig utóbbival ezek mennyiségét befolyásolhatjuk. A nitrogénadszorpciós mérések során a korábbi eredmények alátámasztása mellett kimutattuk, hogy a túlzott energiabevitel a darabolódással szemben a felület csökkenését okozza a nanoméretű partikulumok szintereződése által.

Nyomás és hőmérséklet detektálására alkalmas mérőberendezéssel vizsgáltuk egy modellreakción keresztül a mechanokémiai reakciók kinetikáját. Ehhez az $\mathrm{SnCl}_{2}$ és $\mathrm{Na}_{2} \mathrm{CO}_{3}$ reakciójából származó $\mathrm{CO}_{2}$ keltette nyomásváltozást követtük. Ennek során a nyomás emelkedésében anomáliát fedeztünk fel, melynek magyarázatához részletesen vizsgáltuk a reakciótermékek összetételét. TG és FT-IR spektroszkópiás analízissel kimutattuk, hogy amennyiben $\mathrm{Na}_{2} \mathrm{CO}_{3}$-ot használunk reagensként és a rendszerünkben víz is jelen van, úgy számolni kell $\mathrm{NaHCO}_{3}$ képződésével. Mivel ez végül a $\mathrm{Na}_{2} \mathrm{CO}_{3}$-hoz hasonlóan elbomlik, így a végtermék minőségét nem befolyásolja, ugyanakkor a nyomás változásából levont következtetéseknél figyelembe kell venni. Számunkra a nyomás emelkedése és a konverzió közti párhuzam szempontjából kiemelten fontos volt ez az eredmény. 
A karbonátos szintézis alapos tanulmányozása után több fém-oxid nanorészecske előállítására is kiterjesztettük az eljárást. Így $\mathrm{SnO}_{2}$ szintézise és karakterizálása után sikeresen állítottunk elő nanoméretü $\mathrm{CdO}, \mathrm{CoO}, \mathrm{ZrO}, \mathrm{ZnO}, \mathrm{NiO}, \mathrm{Fe}_{2} \mathrm{O}_{3}$ és $\mathrm{MnO}_{2}$, majd két fémsó prekurzor egyidejü őrlésével $\mathrm{NiFe}_{2} \mathrm{O}_{4}$ részecskéket. $\mathrm{Az}$ őrlések során minden esetben $\mathrm{NaCl}$ mátrixot alkalmaztunk.

A mechanokémiával előidézett fázisátalakulások vizsgálata során bizonyítottuk, hogy megfelelően nagy energiájú őrléssel lehetséges amorf, anatáz, majd rutil kristályszerkezetű $\mathrm{TiO}_{2}$ részecskék előállítása utólagos hőkezelés nélkül. Trititanát nanoszálak mechanokémiai kezelésekor egy olyan nem-egyensúlyi fázisátalakulást tapasztaltunk, melynek során trititanát nanocsöveket, majd amorf és polimorf $\mathrm{TiO}_{2}$ részecskéket kaptunk. Az átalakulás az örlési energia szabályozásával az egyes fázisoknál megállítható, tehát a termék összetétele nem véletlenszerü, hanem előre meghatározható. 


\section{Summary}

My doctoral research focused on the preparation of nanostructures by the mechanochemical route in order to increase the number of materials that can be synthesized this way. In the course of this work, the kinetics of mechanochemical reactions and a model suitable for the calculation of the mechanical energy transferred to the milled system were investigated and selected properties of the synthesized nanoparticles were studied. The main results of this $\mathrm{PhD}$ thesis are the following:

The applicability of the Burgio-Rojac model for the calculation of energy transferred to a nanoparticulate system was investigated. For this work multiwall carbon nanotubes (MWCNT) were milled. A statistical model was developed to describe the length reduction of the MWCNTs and then experimental evidence about the length distribution was collected by TEM. Results were interpreted more successfully in the Burgio-Rojac framework than in the statistical model. Moreover, the effects of certain operational parameters of milling were studied. We demonstrated that the rotational speed of the vial, the milling time and the size and number of the grinding balls influence the shortening of the nanotubes to a different degree. These parameters are not readily interchangeable.

The results of Raman measurements revealed that sufficiently adjusted ball impact and cumulative energies make controlled MWCNT fracture possible. While the ball impact energy controls the number of fractures or breakage of the tubes, the cumulative energy has an effect on the quantity of them. In addition to supporting the previously described results, nitrogen adsorption measurements have shown that excessive mechanical energy causes the sintering of the nanosized particles and leads to the decrease of the specific surface area.

The kinetics of mechanochemical reactions was examined by means of a model reaction. The changes of pressure and temperature were monitored by a GTM-II instrument. $\mathrm{CO}_{2}$ released in the reaction of $\mathrm{SnCl}_{2}$ and $\mathrm{Na}_{2} \mathrm{CO}_{3}$ increases the measured pressure. Our studies have highlighted an unexpected anomaly in pressure evolution that we investigated in detail. The reaction products were analysed by thermogravimetric and FT-IR spectroscopy. We found that as long as water and $\mathrm{CO}_{2}$ are present simultaneously in the milling drum, the latter can be immobilized in the form of $\mathrm{NaHCO}_{3}$. This mechanism decreases the pressure until all the excess $\mathrm{Na}_{2} \mathrm{CO}_{3}$ is consumed in $\mathrm{CO}_{2}$ capture; then the decomposition of $\mathrm{NaHCO}_{3}$ 
causes the sudden, anomalous increase of pressure. Since pressure measurement is frequently used to monitor the progress of the reaction, this finding is considered to be very important.

After the in-depth study of $\mathrm{SnO}_{2}$ nanoparticle synthesis through the carbonate mechanochemical route, the procedure was extended to the synthesis of other metal-oxide nanoparticles as well. $\mathrm{CdO}, \mathrm{CoO}, \mathrm{ZrO}, \mathrm{ZnO}, \mathrm{NiO}, \mathrm{Fe}_{2} \mathrm{O}_{3}$ and $\mathrm{MnO}_{2}$ were successfully synthesized this way. Co-milling milling of $\mathrm{FeCl}_{3}$ and $\mathrm{NiCl}_{2}$ allowed us synthesize $\mathrm{NiFe}_{2} \mathrm{O}_{4}$ nanoparticles of high coercivity. In every case $\mathrm{NaCl}$ was used as the milling medium.

We proved that it is possible to prepare $\mathrm{TiO}_{2}$ nanoparticles of amorphous, anatase and rutile crystal structure without any heat treatment by high energy ball milling. Furthermore, the non-equilibrium transformation of titanate nanowires into nanotubes upon mechanochemical activation was investigated. It was found that there is an optimal individual ball impact energy that facilitates nanowire to nanotube conversion the most. Investing more grinding energy induced nanotube fracture into nanoparticles. Each phase transformation was fully controllable by controlling the ball impact energy carefully. 


\section{Köszönetnyilvánítás}

Elsősorban köszönettel tartozom témavezetőmnek, Dr. Kukovecz Ákos egyetemi docensnek a munkám során az eredményeim értelmezésében és publikálásában, valamint a dolgozat megírása közben nyújtott végtelen segítségéért. Köszönöm Dr. Kiricsi Imre egykori tanszékvezető egyetemi tanárnak és Dr. Kónya Zoltán tanszékvezető egyetemi tanárnak, hogy lehetővé tették, hogy az Alkalmazott és Környezeti Kémiai Tanszéken kezdhettem tudományos pályafutásom, illetve hogy a mai napig is ugyanitt dolgozhatok.

Természetesen köszönöm a tanszék összes volt és jelenlegi dolgozójának a legkülönfélébb segítséget, amelyet munkám során nyújtottak.

Külön szeretném megköszönni Berkesi Dánielnek, Madarász Dánielnek, Szenti Imrének, Dr. Pusztai Péternek és még Dr. Puskás Róbertnek is a folyamatos érdeklődést és lelkesítést, és föként azt a légkört, ami a dolgozat írása közben körülvett.

Köszönöm Dr. Tadej Rojacnak és Dr. Marija Kosecnek a Jozef Stefan Institute szlovén egyetemen töltött igen hasznos kutatómunka lehetőségének megteremtését.

Köszönettel tartozom családomnak a tanulmányaim során nyújtott segítségért, hogy ameddig csak tudtak, minden erejükből támogattak az idáig vezető úton.

Végül, de nem utolsó sorban szeretném végtelen hálámat kifejezni feleségemnek, Tímeának, aki végigkísért, elviselt, támogatott és hitt bennem az egész úton. 


\section{Irodalomjegyzék}

1. Nakamura S, Isobe T, Senna M. Hydroxyapatite nano sol prepared via a mechanochemical route. Journal of Nanoparticle Research. 2001;3(1):57-61.

2. Scholz G, Feist $M$, Kemnitz E. On the influence of humidity on the mechanochemical reaction between NaF and AIF(3). Solid State Sciences. 2008;10(11):1640-1650.

3. Suryanarayana C, Ivanov E, Boldyrev VV. The science and technology of mechanical alloying. Materials Science and Engineering a-Structural Materials Properties Microstructure and Processing. May 31 2001;304:151-158.

4. Boldyrev VV. Mechanical activation and its application in technology. In: Baro MD, Surinach S, eds. Mechanically Alloyed, Metastable and Nanocrystalline Materials, Part 1. Vol 269-2; 1998: 227-234.

5. Takacs L. Quicksilver from Cinnabar: The first documented mechanochemical reaction? JomJournal of the Minerals Metals \& Materials Society. 2000;52(1):12-13.

6. Faraday M. Chemical manipulation [microform] : being instructions to students in chemistry, on the methods of performing experiments of demonstration or of research, with accuracy and success / by Michael Faraday. London: W. Phillips; 1827.

7. Britain. RloG. Quarterly Journal of Science, Literature and the Arts. Vol Vol VIII - Vol VIII. London.; 1820.

8. Lea MC. XXVI. On gold-coloured allotropic silver-Part I. Philosophical Magazine Series 5. 1891 1891;31(190):238-250.

9. Lea MC. XXXVI. On allotropic silver. Philosophical Magazine Series 5. 1891 1891;31(191):320329.

10. Lea MC. IV. Disruption of the silver haloid molecule by mechanical force. Philosophical Magazine Series 5. 1892 1892;34(206):46-50.

11. Lea MC. III. On endothermic decompositions obtained by pressure. (Second part.) Transformations of energy by shearing stress. Philosophical Magazine Series 5. 1894 1894;37(224):31-38.

12. Takacs L. M. Carey Lea, the first mechanochemist. Journal of Materials Science. 2004;39(1617):4987-4993.

13. Parker LH. XXXIV.-Reactions between solid substances. Journal of the Chemical Society, Transactions. 1918;113(0):396-409.

14. Bowden FP, Tabor D. The friction and lubrication of solids. Oxford: Clarendon Press; 1950.

15. Bowden FP, Yoffe AD. Fast reactions in solids. London: Butterworth's Scientific Publications; 1958.

16. Bowden FP, Yoffe AD. Initiation and growth of explosion in liquids and solids. University Press.

17. Tammann G. Der einfluss der kaltbearbeitung auf die chemischen eigenschaften insbesondere von metallen. Zeitschrift für Elektrochemie und angewandte physikalische Chemie. 1929;35(1):21-28.

18. Boldyrev VV, Tkacova K. Mechanochemistry of solids: Past, present, and prospects. Journal of Materials Synthesis and Processing. 2000;8(3-4):121-132.

19. Fink M, Hofmann U. Oxydation von Metallen unter dem Einfluß der Reibung. Zeitschrift für anorganische und allgemeine Chemie. 1933;210(1):100-104.

20. Bowden FP. The friction and lubrication of solids / by F.P. Bowden and D. Tabor. Oxford: Clarendon Press; 1950.

21. Jamison WE. G. Heinicke, Tribochemistry (Carl Hanser Verlag, Munich, 1985, 495 pp, DM128, US\$48). Journal of Synthetic Lubrication. 1986;3(1):55-56. 
22. Boldyrev VV. Introduction: Ten years after the first international conference on mechanochemistry and mechanical alloying; where we are now. Journal of Materials Science. 2004/08/01 2004;39(16-17):4985-4986.

23. Weichert R, Schönert K. On the temperature rise at the tip of a fast running crack + . Journal of the Mechanics and Physics of Solids. 3// 1974;22(2):127-133.

24. Fox PG, Soria-Ruiz J. Fracture-Induced Thermal Decomposition in Brittle Crystalline Solids. Proceedings of the Royal Society of London Series A, Mathematical and Physical Sciences. 1970;317(1528):79-90.

25. Lyakhov NZ. Achievements and prospects in mechanochemistry. Vestnik Akademii Nauk Sssr. 1988 1988(8):65-74.

26. Boldyrev VV. Mechanochemistry and mechanical activation of solids. Uspekhi Khimii. 2006;75(3):203-216.

27. Stranski IN. Book Review: Grundlagen der Tribochemie (Fundamentals of Tribochemistry). By P.-A. Thiessen, K. Meyer, and G. Heinicke. Angewandte Chemie International Edition in English. 1968;7(7):556-556.

28. Heinicke G, Sigrist K. Zur Thermodynamik tribochemischer Reaktionen. Zeitschrift für Chemie. 1971;11(6):226-235.

29. Kühn M. P. A. Thiessen, K. Meyer, G. Heinicke. Grundlagen der Tribochemie Abhandlungen der DAW zu Berlin, Lasse für Chemie, Geologie und Biologie, Jahrgang 1966, Nr. 1. 194 Seiten, zahlreiche Abbildungen, Tabellen und Literatur-Zitate. Geh. 33.- Akademie-Verlag Berlin 1967. Kristall und Technik. 1970;5(4):K13-K13.

30. Heinicke G, Hennig HP, Linke E, Steinike U, Thiessen KP, Meyer K. Tribochemistry AkademieVerlag, Berlin 1984495 S., 329 Abb., 106 Tab. Preis: 98, - M. Crystal Research and Technology. 1984;19(11):1424-1424.

31. Movchan TG, Esipova NE, Eryukin PV, Uriev NB, Rusanov Al. Mechanochemical Effects in Processes of Corrosion of Metals. Russ J Gen Chem. 2005/11/01 2005;75(11):1681-1686.

32. Bartenev GM, Razumovskaya IV. Phonon theory of brittle fracture of solids. Mater Sci. 1972 1972;5(1):44-49.

33. Smekal A. Ritzvorgang und molekulare Festigkeit. Naturwissenschaften. 1942 1942;30(1415):224-225.

34. Boldyrev VV. Mechanochemistry and mechanical activation of solids. Solid State lonics. 1993;63-5:537-543.

35. Boldyrev VV. Mechanochemistry and mechanical activation. In: Schulz R, ed. Metastable, Mechanically Alloyed and Nanocrystalline Materials, Pts 1 and 2. Vol 225; 1996: 511-519.

36. Pavlyukhin YT, Medikov YY, Boldyrev VV. On the consequences of mechanical activation of zinc and nickel ferrites. Journal of Solid State Chemistry. 1984 1984;53(2):155-160.

37. Paudert $\mathrm{R}$, Harenz $\mathrm{H}$, Heinicke $\mathrm{G}$, et al. Increase in the reactivity of apatitic phosphates due to mechanical activation. Zeitschrift Fur Anorganische Und Allgemeine Chemie. 1979 1979;452(MAY):141-150.

38. Gaponov YA, Lyakhov NZ, Tolochko BP, Boldyrev VV, Sheromov MA. Study of reaction interface during the topochemical reactions by means of the diffraction methods using synchrotron radiation. Izvestiya Sibirskogo Otdeleniya Akademii Nauk Sssr Seriya Khimicheskikh Nauk. 1985 1985(3):22-27.

39. Pavliukhin IT, Medikov JJ, Boldyrev VV. Change of the cation distribution in ferrites spinels as a result of their mechanical activation. Doklady Akademii Nauk Sssr. 1982 1982;266(6):14201423.

40. Pavlukhin YT, Medikov YY, Boldyrev VV. The mechanism and stages of the mechanical activation of some ferrites-spineles. Izvestiya Sibirskogo Otdeleniya Akademii Nauk Sssr Seriya Khimicheskikh Nauk. 1983 1983(5):46-53.

41. Koch W, Schwarz H. Structures and stabilities of isomers - an abinitio molecular-orbital study. Chemical Physics Letters. 1985 1985;113(2):145-150. 
42. Maurice DR, Courtney TH. The physics of mechanical alloying Metallurgical Transactions aPhysical Metallurgy and Materials Science. Feb 1990;21(2):289-303.

43. Boldyrev VV, Regel VR, Pozdnyakov OF, Urakaev FK, Bylskii BY. IInvestigation of chemicalreactions in destruction of inorganic salt crystals. Doklady Akademii Nauk Sssr. 1975 1975;221(3):634-637.

44. Urakaev FK, Boldyrev VV, Pozdnyakov OF, Regel VR. Study of mechanism of mechanochemical decomposition of solid inorganic-compounds. Kinetics and Catalysis. 1977 1977;18(2):292-299.

45. Goldberg EL, Pavlov SV. Modeling fracture in a restricted impact .1. individual fracture of particles. Soviet Powder Metallurgy and Metal Ceramics. Jul 1990;29(7):509-513.

46. Boldyrev VV, Pavlov SV, Goldberg EL. Interrelation between fine grinding and mechanical activation. International Journal of Mineral Processing. 1996;44-5:181-185.

47. Rojac T, Masson O, Guinebretiere R, Kosec M, Malic B, Holc J. A study of the mechanochemical synthesis of $\mathrm{NaNbO3.} \mathrm{Journal} \mathrm{of} \mathrm{the} \mathrm{European} \mathrm{Ceramic} \mathrm{Society.} 2007$ 2007;27(5):2265-2271.

48. Butyagin PY, Streletskii AN, Morozova OS, Leonov AV, Berestetskaya IV, Borunova AB. Mechanically-induced chemical conversions in a $\mathrm{Zr}-\mathrm{Co}-\mathrm{H}-2$ system. Basic reactions. Chemical Physics Reports. 1998 1998;17(3):521-542.

49. Butyagin PY. Structure disordering and mechanochemical reactions in solid states. Uspekhi Khimii. 1984;53(11):1769-1789.

50. Abagyan GV, Butyagin PY. Mechanically initiated free-radical reactions in polysaccharides. Vysokomolekulyarnye Soedineniya Seriya A. 1984;26(6):1311-1317.

51. Schrader R, Werner KH. Mechanical activation of technical silicon for direct synthesis of methyl chlorosilanes. Chemische Technik. 1975 1975;27(3):156-157.

52. Bade S, Hoffmann U. Development of a new reactor for combined comminution and chemical reaction. Chemical Engineering Communications. 1996 1996;143:169-193.

53. Thiessen PA, Heinicke G, Schober E. Zur tribochemischen Umsetzung von Gold und $\mathrm{CO} 2$ mit Hilfe radioaktiver Markierung. Zeitschrift für anorganische und allgemeine Chemie. 1970;377(1):20-28.

54. Mori S, Xu WC, Ishidzuki T, Ogasawara N, Imai J, Kobayashi K. Mechanochemical activation of catalysts for CO2 methanation. Applied Catalysis a-General. Apr 11 1996;137(2):255-268.

55. Buyanov RA. Mechanism of deactivation of heterogeneous catalysts. Kinetics and Catalysis. 1987;28(1):138-145.

56. Molchanov VV, Buyanov RA. Mechanochemistry of catalysts. Uspekhi Khimii. 2000 2000;69(5):476-493.

57. Mulas G, Schiffini L, Scudino S, Cocco G. Mechanochemical hydrogenation of ZrCuAINi based powders - Part II. Mechanical treatment intensity and kinetic behaviour. Journal of Alloys and Compounds. May 8 2008;455(1-2):106-112.

58. Gerasimov KB, Goldberg EL, Ivanov EY. The kinetic-model of magnesium hydrogenation. Izvestiya Sibirskogo Otdeleniya Akademii Nauk Sssr Seriya Khimicheskikh Nauk. 1985(6):6674.

59. Ivanov E, Konstanchuk I, Stepanov A, Boldyrev V. Magnesium mechanical alloys for hydrogen storage. Journal of the Less-Common Metals. 1987;131:25-29.

60. Zaluski L, Zaluska A, Tessier P, StromOlsen JA, Schulz R. Hydrogen absorption by nanocrystalline and amorphous $\mathrm{Fe}-\mathrm{Ti}$ with palladium catalyst, produced by ball milling. Journal of Materials Science. Feb 1 1996;31(3):695-698.

61. Wasz ML, Schwarz RB. Structure and properties of metal hydrides prepared by mechanical alloying. In: Schulz R, ed. Metastable, Mechanically Alloyed and Nanocrystalline Materials, Pts 1 and 2. Vol 225; 1996: 859-867.

62. Fujii $\mathrm{H}$, Munehiro $\mathrm{S}$, Fujii $\mathrm{K}$, Orimo $\mathrm{S}$. Effect of mechanical grinding under $\mathrm{Ar}$ and $\mathrm{H}-2$ atmospheres on structural and hydriding properties in LaNi5. Journal of Alloys and Compounds. Jan 17 2002;330:747-751. 
63. Bobet JL, Chevalier B, Song MY, Darriet B, Etourneau J. Hydrogen sorption of Mg-based mixtures elaborated by reactive mechanical grinding. Journal of Alloys and Compounds. 2002;336(1-2):292-296.

64. Mulas G, Schiffini L, Cocco G. Mechanochemical study of the hydriding properties of nanostructured Mg2Ni-Ni composites. Journal of Materials Research. Nov 2004;19(11):32793289.

65. Balaz $\mathrm{P}$, Achimovicova $\mathrm{M}$. Mechano-chemical leaching in hydrometallurgy of complex sulphides. Hydrometallurgy. Oct 2006;84(1-2):60-68.

66. Balaz P. Mechanical activation in hydrometallurgy. International Journal of Mineral Processing. Sep 29 2003;72(1-4):341-354.

67. Shakhtshneider TP, Boldyrev VV. Phase-transformations in sulfathiazole during mechanical activation. Drug Development and Industrial Pharmacy. 1993 1993;19(16):2055-2067.

68. Li XH, Zhang YJ, Pan LP, Wei YS. Effect of mechanical activation on dissolution kinetics of neutral leach residue of zinc calcine in sulphuric acid. Transactions of Nonferrous Metals Society of China. May 2013;23(5):1512-1519.

69. Goldberg EL, Pavlov SV, Eremin AF, Urakaev FH. Mechanical activation of sodium-fluoride .6. peculiarities of dissolving kinetic in alcohol of active powders. Izvestiya Sibirskogo Otdeleniya Akademii Nauk Sssr Seriya Khimicheskikh Nauk. 1986(5):41-44.

70. Li C, Liang B, Guo L-H. Dissolution of mechanically activated Panzhihua ilmenites in dilute solutions of sulphuric acid. Hydrometallurgy. Sep 2007;89(1-2):1-10.

71. Varentsova VI. Application of tribogalvanic effect in study of mechanically activated powders (cadmium sulfide taken as example). J Min Sci. 1993/03/01 1993;29(2):186-189.

72. Boldyrev VV. Reactivity of solids : past, present, and future. Cambridge, Mass.: Blackwell Science; 1996.

73. Grigorieva TF, Barinova AP, Boldyrev VV, Ivanov EY. The influence of structural relationship on extended solid solubility at mechanical alloying. Solid State lonics. Nov 1997;101:17-24.

74. Tongsri R, Tosangthum N. Solid state transformation of non-equilibrium Ni-Sn powder with a eutectic composition. Songklanakarin Journal of Science \& Technology. 2011;33(2):209-214.

75. Gaffet E, Malhourouxgaffet N, Abdellaoui M, Malchere A. Phase-transitions under mechanical stresses - production, using mechanosynthesis of nanomaterials (metallic alloys, semiconductors, ceramics. Revue De Metallurgie-Cahiers D Informations Techniques. May 1994;91(5):757-769.

76. Schaffer GB, McCormick PG. Reduction of metal-oxides by mechanical alloying. Applied Physics Letters. Jul 3 1989;55(1):45-46.

77. Schaffer GB, McCormick PG. Combustion synthesis by mechanical alloying. Scripta Metallurgica. Jun 1989;23(6):835-838.

78. Knieke C, Berger A, Voigt M, Taylor RNK, Rohrl J, Peukert W. Scalable production of graphene sheets by mechanical delamination. Carbon. Sep 2010;48(11):3196-3204.

79. Levitas VI, Asay BW, Son SF, Pantoya M. Mechanochemical mechanism for fast reaction of metastable intermolecular composites based on dispersion of liquid metal. Journal of Applied Physics. Apr 15 2007;101(8).

80. Bhattacharya P, Bellon P, Averback RS, Hales SJ. Nanocrystalline TiAl powders synthesized by high-energy ball milling: effects of milling parameters on yield and contamination. Journal of Alloys and Compounds. 2004;368(1-2):187-196.

81. Cedeno-Mattei Y, Perales-Perez O, Uwakweh ONC. Effect of high-energy ball milling time on structural and magnetic properties of nanocrystalline cobalt ferrite powders. Journal of Magnetism and Magnetic Materials. 2013;341:17-24.

82. Pal SK, Schultz L, Gutfleisch O. Effect of milling parameters on SmCo5 nanoflakes prepared by surfactant-assisted high energy ball milling. Journal of Applied Physics. Jan 2013;113(1).

83. Zhang D, Cai R, Zhou YK, Shao ZP, Liao XZ, Ma ZF. Effect of milling method and time on the properties and electrochemical performance of LiFePO4/C composites prepared by ball milling and thermal treatment. Electrochimica Acta. Mar 2010;55(8):2653-2661. 
84. Chen Y, Williams JS. High-energy ball-milling-induced non-equilibrium phase transformations. Materials Science and Engineering: A. 6/15/ 1997;226-228:38-42.

85. Dutta H, Manik SK, Pradhan SK. Phase transformation kinetic study and microstructure characterization of ball-milled m-ZrO2-10 mol\% a-TiO2 by Rietveld method. Journal of Applied Crystallography. 2003;36:260-268.

86. Fox PG. Mechanically initiated chemical-reactions in solids. Journal of Materials Science. 1975;10(2):340-360.

87. Schönert K, Steier K. Die Grenze der Zerkleinerung bei kleinen Korngrößen. Chemie Ingenieur Technik. 1971;43(13):773-777.

88. Avvakumov EG, Kosova NV. FAST PROPAGATING SOLID-STATE MECHANOCHEMICAL REACTIONS. Sibirskii Khimicheskii Zhurnal. 1991(5):62-66.

89. Avvakumov E, Senna M, Kosova N. Soft mechanochemical synthesis a basis for new chemical technologies. Kluwer Academic Publishers.

90. Brayman CL, Pugh MD, Drew RAL. Ball milling and sintering of bayer aluminas. Canadian Metallurgical Quarterly. 1989;28(4):293-299.

91. Gajovic A, Furic K, Stefanic G, Music S. In situ high temperature study of ZrO2 ball-milled to nanometer sizes. Journal of Molecular Structure. 2005;744:127-133.

92. Rojas-Hernandez RE, Rubio-Marcos F, Enriquez E, De La Rubia MA, Fernandez JF. A lowenergy milling approach to reduce particle size maintains the luminescence of strontium aluminates. Rsc Advances. 2015;5(53):42559-42567.

93. Rojac T, Kosec A, Malic B, Holc J. The application of a milling map in the mechanochemical synthesis of ceramic oxides. Journal of the European Ceramic Society. 2006;26(16):37113716.

94. Lintz M. Apparatus for reject jigging. Google Patents; 1950.

95. Gock E, Kurrer KE. Eccentric vibratory mills - theory and practice. Powder Technology. Nov 1999;105(1-3):302-310.

96. Beenken W, Gock E, Kurrer KE. The outer mechanics of the eccentric vibration mill. International Journal of Mineral Processing. Mar 1996;44-5:437-446.

97. Suryanarayana C, Chen GH, Frefer A, Fores FH. Structural evolution of mechanically alloyed ti-al alloys. Materials Science and Engineering a-Structural Materials Properties Microstructure and Processing. Oct 1992;158(1):93-101.

98. Venkataswamy MA, Schneider JA, Groza JR, Mukherjee AK, Yamazaki K, Shoda K. Mechanical alloying processing and rapid plasma activated sintering consolidation of nanocrystalline iron-aluminides. Materials Science and Engineering a-Structural Materials Properties Microstructure and Processing. Mar 1996;207(2):153-158.

99. Guwer A, Nowosielski R, Lebuda A. Properties and structure of cu-ti-zr-ni amorphous powders prepared by mechanical alloying. Materiali in Tehnologije. 2015;49(3):423-427.

100. Adamek G. Mechanical Alloying of Ti-20Ta-20Nb-(10 divided by 20)Mg Alloys. Acta Physica Polonica A. 2014;126(4):871-874.

101. Benjamin JS. Mechanical alloying. Scientific American. 1976;234(5):40-49.

102. Andrew S. Fine grinding apparatus. Google Patents; 1971.

103. Balaz P, Godocikova E, Kril'ova L, Lobotka P, Gock E. Preparation of nanocrystalline materials by high-energy milling. Materials Science and Engineering a-Structural Materials Properties Microstructure and Processing. 2004;386(1-2):442-446.

104. Klimpel RR. Introduction to the Principles of Size Reduction of Particles by Mechanical Means. Engineering Research. 1997.

105. Crites J. Planetary ball mill/US1912761 A. US Patents; 1933.

106. Alkebro J, Begin-Colin S, Mocellin A, Warren R. Modeling high-energy ball milling in the alumina-yttria system. Journal of Solid State Chemistry. 2002;164(1):88-97.

107. Chattopadhyay PP, Manna I, Talapatra S, Pabi SK. A mathematical analysis of milling mechanics in a planetary ball mill. Materials Chemistry and Physics. 2001;68(1-3):85-94. 
108. Lebrun P, Froyen L, Delaey L. The modeling of the mechanical alloying process in a planetary ball mill - comparison between theory and insitu observations. Materials Science and Engineering a-Structural Materials Properties Microstructure and Processing. Mar 15 1993;161(1):75-82.

109. Rosenkranz S, Breitung-Faes S, Kwade A. Experimental investigations and modelling of the ball motion in planetary ball mills. Powder Technology. Sep 2011;212(1):224-230.

110. Ashrafizadeh $H$, Ashrafizaadeh $M$. Influence of processing parameters on grinding mechanism in planetary mill by employing discrete element method. Advanced Powder Technology. 2012;23(6):708-716.

111. Hofmann M, Campbell SJ, Kaczmarek WA. Mechanochemical transformation of haematite to magnetite: Structural investigation. In: Cernik RJ, Delhez R, Mittemeijer EJ, eds. European Powder Diffraction: Epdic Iv, Pts 1 and 2. Vol 228; 1996: 607-613.

112. Gotor FJ, Achimovicova M, Real C, Balaz P. Influence of the milling parameters on the mechanical work intensity in planetary mills. Powder Technology. 1// 2013;233:1-7.

113. Zhao L, Zwick J, Lugscheider E. The influence of milling parameters on the properties of the milled powders and the resultant coatings. Surface and Coatings Technology. 5/22/ 2003;168(2-3):179-185.

114. Wehrstedt A. Uniform standardization for Brinell, Vickers and Rockwell hardness testing methods. Stahl Und Eisen. Jul 2000;120(7):79-84.

115. Schnatz R. Optimization of continuous ball mills used for finish-grinding of cement by varying the L/D ratio, ball charge filling ratio, ball size and residence time. International Journal of Mineral Processing. 12/10/ 2004;74, Supplement:S55-S63.

116. Schnatz R, Knobloch $\mathrm{O}$. Influence of the ball filling factor on the power consumption and throughput of ball mills in combined grinding plants. Zkg International. 2000;53(8):438-+.

117. Kuziora P, Wyszyńska M, Polanski M, Bystrzycki J. Why the ball to powder ratio (BPR) is insufficient for describing the mechanical ball milling process. International Journal of Hydrogen Energy. 6/15/ 2014;39(18):9883-9887.

118. Zakeri M, Razavi M, Rahimipour MR, Abbasi BJ. Effect of ball to powder ratio on the ZrO2 phase transformations during milling. Physica B-Condensed Matter. Jul 2014;444:49-53.

119. Lv YJ, Su J, Long YF, Cui XR, Lv XY, Wen YX. Effects of ball-to-powder weight ratio on the performance of LiFePO4/C prepared by wet-milling assisted carbothermal reduction. Powder Technology. Feb 2014;253:467-473.

120. Eleskandarany MS, Aoki K, Itoh H, Suzuki K. Effect of ball-to-powder weight ratio on the amorphization reaction of al50ta50 by ball milling. Journal of the Less-Common Metals. 1991;169(2):235-244.

121. Bhatt J, Murty BS. On the conditions for the synthesis of bulk metallic glasses by mechanical alloying. Journal of Alloys and Compounds. 2008;459(1-2):135-141.

122. Ong TS, Yang H. Effect of atmosphere on the mechanical milling of natural graphite. Carbon. 2000;38(15):2077-2085.

123. Prasad BM, Sain MM, Roy DN. Properties of ball milled thermally treated hemp fibers in an inert atmosphere for potential composite reinforcement. Journal of Materials Science. Aug 2005;40(16):4271-4278.

124. Song MY, Baek SH, Bobet JL, Hong SH. Hydrogen storage properties of a Mg-Ni-Fe mixture prepared via planetary ball milling in a $\mathrm{H}-2$ atmosphere. International Journal of Hydrogen Energy. Oct 2010;35(19):10366-10372.

125. Francke M, Hermann H, Wenzel R, Seifert G, Wetzig K. Modification of carbon nanostructures by high energy ball-milling under argon and hydrogen atmosphere. Carbon. 2005;43(6):12041212.

126. Edalati K, Horita Z, Fujiwara H, Ameyama K. Cold Consolidation of Ball-Milled Titanium Powders Using High-Pressure Torsion. Metallurgical and Materials Transactions a-Physical Metallurgy and Materials Science. 2010;41A(13):3308-3317. 
127. Kaczmarek WA. Ball milling of barium ferrite in air and vacuum. Journal of Materials Science. Oct 1996;31(19):5271-5279.

128. Burgio N, lasonna A, Magini M, Martelli S, Padella F. Mechanical alloying of the fe-zr system correlation between input energy and end-products. Nuovo Cimento Della Societa Italiana Di Fisica D-Condensed Matter Atomic Molecular and Chemical Physics Fluids Plasmas Biophysics. 1991;13(4):459-476.

129. Magini M, lasonna A, Padella F. Ball milling: An experimental support to the energy transfer evaluated by the collision model. Scripta Materialia. Jan 1996;34(1):13-19.

130. Magini M, lasonna A. Energy-transfer in mechanical alloying. Materials Transactions Jim. Feb 1995;36(2):123-133.

131. Wu CX, Zhu SG, Ma J, Zhang ML. Synthesis and formation mechanisms of nanocomposite WC-MgO powders by high-energy reactive milling. Journal of Alloys and Compounds. Jun 10 2009;478(1-2):615-619.

132. Joardar J, Pabi SK, Murty BS. Milling criteria for the synthesis of nanocrystalline NiAl by mechanical alloying. Journal of Alloys and Compounds. Jan 21 2007;429(1-2):204-210.

133. Abdellaoui M, Gaffet E. A mathematical and experimental dynamical phase-diagram for ballmilled ni10zr7. Journal of Alloys and Compounds. 1994;209:351-361.

134. Kulebakin VG. The Use of Mechanochemistry in Hydrometallurgical Processes. 1988.

135. Tkácová K. Mechanical activation of minerals. Amsterdam; New York; New York, NY: Elsevier ; Distribution for the U.S.A. and Canada Elsevier Science Pub. Co.; 1989.

136. Boldyrev VV, Kolosov AS, Chaikina MV, Avvakumov EG. Mechanical activation of apatite and apatite-containing rocks. Doklady Akademii Nauk Sssr. 1977 1977;233(5):892-895.

137. Paudert R, Harenz H, Pothig R, Heinicke G, Dunkel L, Schumann H. Phosphate fertilizers by tribomechanical activation of apatitic phosphates. Chemische Technik. 1978;30(9):470-475.

138. Chaikina MV, Avvakumov EGe, Institut khimii tverdogo tela i m. Mekhanokhimiia prirodnykh i sinteticheskikh apatitov. Novosibirsk: Izd-vo SO RAN, Filial "GEO"; 2002.

139. Gaffet E, Tillement O. Mechanochemistry and mechanical activation. Annales De ChimieScience Des Materiaux. 1997;22(6):417-422.

140. V. Molchanov V, A. Buyanov R. Mechanochemistry of catalysts. Russian Chemical Reviews. 2000;69(5):435-450.

141. Wieczorek-Ciurowa K, Gamrat K, Shirokov JG. Mechanism of mechanochemical reactions in malachite-active metal systems. TCA</cja:jid> Thermochimica Acta. 2003;400(1):221-225.

142. Firsova AA, Morozova OS, Leonov AV, Streletskii AN, Korchak VN. Mechanochemical synthesis of $\mathrm{CuO}-\mathrm{CeO} 2$ catalysts for the preferential oxidation of $\mathrm{CO}$ in the presence of $\mathrm{H}-2$. Kinetics and Catalysis. 2014;55(6):777-785.

143. Avvakumov EG, Gusev AA. Cordierite: A Promising Ceramic Material. INORGANIC MATERIALS C/C OF IZVESTIIA- AKADEMIIA NAUK SSSR NEORGANICHESKIE MATERIALY. 2001;37:868-869.

144. Liu X, Wang J, Ding J, Chen MS, Shen ZX. The effects of mechanical activation in synthesizing ultrafine barium ferrite powders from co-precipitated precursors. Journal of Materials Chemistry. 2000;10(7):1745-1749.

145. Ashiri R. On the solid-state formation of $\mathrm{BaTiO}$ nanocrystals from mechanically activated $\mathrm{BaCO} 3$ and $\mathrm{TiO} 2$ powders: innovative mechanochemical processing, the mechanism involved, and phase and nanostructure evolutions. Rsc Advances. 2016;6(21):17138-17150.

146. Cherkezova-Zheleva Z, Blaskov V, Mitov I, Klissurski D, Radev D, Tsokov P. Mechanochemically Activated Synthesis of Nanostructured NiFe2O4. Inorganic Materials. 2011;47(5):527-530.

147. Konstanchuk IG, Ivanov EY, Boldyrev VV. Interaction of alloys and intermetallic compounds obtained by mechanochemical methods with hydrogen. Russ Chem Rev Russian Chemical Reviews. 1998;67(1):69-79.

148. Pukazhselvan D, Perez J, Nasani N, Bdikin I, Kovalevsky AV, Fagg DP. Formation of MgxNbyOx+y through the Mechanochemical Reaction of $\mathrm{MgH} 2$ and $\mathrm{Nb2O5}$, and Its Effect on the Hydrogen-Storage Behavior of MgH2. Chemphyschem. Jan 2016;17(1):178-183. 
149. Boldyrev VV, Gabuda SP, Drebushchak IV, Mikhailenko MA, Shakhtshneider TP. Modification of the electronic state of indomethacin by mechanical activation. Dokl Phys Chem Doklady Physical Chemistry. 2009;427(1):117-120.

150. Dadali AA, Lastenko IP, Aksenenkov VV, Ivanov AN. ChemInform Abstract: Radical Processes in Organic Crystals Induced by Shear Deformation Under Pressure. CHIN ChemInform. 1993;24(22):no.

151. Pantic J, Prekajski M, Dramicanin M, et al. Preparation and characterization of chrome doped sphene pigments prepared via precursor mechanochemical activation. Journal of Alloys and Compounds. Dec 2013;579:290-294.

152. Takahashi M, Kitamoto D, Asikin Y, Takara K, Wada K. Liposomes Encapsulating Aloe vera Leaf Gel Extract Significantly Enhance Proliferation and Collagen Synthesis in Human Skin Cell Lines. Journal of Oleo Science. Dec 2009;58(12):643-650.

153. Tongamp W, Zhang Q, Saito F. Mechanochemical decomposition of PVC by using La2O3 as additive. Journal of Hazardous Materials. Sep 21 2006;137(2):1226-1230.

154. Inoue T, Kano J, Saito F. Influence of plastisizer on mechanochemical dechlorination reaction between PVC and NaOH. Kagaku Kogaku Ronbunshu. May 2006;32(3):215-219.

155. Tongamp W, Kano J, Zhang Q, Saito F. Simultaneous treatment of PVC and oyster-shell wastes by mechanochemical means. Waste Management. 2008;28(3):484-488.

156. Drexler KE. The Coming Era of Nanotechnology. Engines of Creation. 1986;100(100):100.

157. Wang YL, Xia YN. Bottom-up and top-down approaches to the synthesis of monodispersed spherical colloids of low melting-point metals. Nano Letters. Oct 2004;4(10):2047-2050.

158. Iijima S. Helical microtubules of graphitic carbon. Nature. Nov 1991;354(6348):56-58.

159. Kukovecz A, Konya Z, Nagaraju N, et al. Catalytic synthesis of carbon nanotubes over Co, Fe and $\mathrm{Ni}$ containing conventional and sol-gel silica-aluminas. Physical Chemistry Chemical Physics. 2000;2(13):3071-3076.

160. Ma PC, Wang SQ, Kim JK, Tang BZ. In-Situ Amino Functionalization of Carbon Nanotubes Using Ball Milling. Journal of Nanoscience and Nanotechnology. Feb 2009;9(2):749-753.

161. Liu ZY, Xu SJ, Xiao BL, Xue P, Wang WG, Ma ZY. Effect of ball-milling time on mechanical properties of carbon nanotubes reinforced aluminum matrix composites. Composites Part aApplied Science and Manufacturing. Dec 2012;43(12):2161-2168.

162. Li YB, Wei BQ, Liang J, Yu Q, Wu DH. Transformation of carbon nanotubes to nanoparticles by ball milling process. Carbon. 1999;37(3):493-497.

163. Jia ZJ, Wang ZY, Liang J, Wei BQ, Wu DH. Production of short multi-walled carbon nanotubes. Carbon. 1999;37(6):903-906.

164. Kukovecz Á, Kanyó T, Kónya Z, Kiricsi I. Long-time low-impact ball milling of multi-wall carbon nanotubes. Carbon. // 2005;43(5):994-1000.

165. Pierard N, Fonseca A, Konya Z, Willems I, Van Tendeloo G, Nagy JB. Production of short carbon nanotubes with open tips by ball milling. Chemical Physics Letters. Feb 2001;335(12):1-8.

166. Esawi AMK, Morsi K, Sayed A, Gawad AA, Borah P. Fabrication and properties of dispersed carbon nanotube-aluminum composites. Materials Science and Engineering a-Structural Materials Properties Microstructure and Processing. 2009;508(1-2):167-173.

167. Serp P, Corrias M, Kalck P. Carbon nanotubes and nanofibers in catalysis. Applied Catalysis aGeneral. Oct 28 2003;253(2):337-358.

168. Dillon AC, Jones KM, Bekkedahl TA, Kiang CH, Bethune DS, Heben MJ. Storage of hydrogen in single-walled carbon nanotubes. Nature. 1997;386(6623):377-379.

169. Coleman JN, Khan U, Blau WJ, Gun'ko YK. Small but strong: A review of the mechanical properties of carbon nanotube-polymer composites. Carbon. 2006;44(9):1624-1652.

170. Taurino AM, Epifani M, Toccoli T, lannotta S, Siciliano P. Innovative aspects in thin film technologies for nanostructured materials in gas sensor devices. Thin Solid Films. Jul 22 2003;436(1):52-63. 
171. Liu Y, Zhu W, Tan OK, Shen Y. Structural and gas sensing properties of ultrafine Fe2O3 prepared by plasma enhanced chemical vapor deposition. Materials Science and Engineering B-Solid State Materials for Advanced Technology. Jun 15 1997;47(2):171-176.

172. Sivakumar R, Gopalakrishnan R, Jayachandran M, Sanjeeviraja C. Preparation and characterization of electron beam evaporated WO3 thin films. Optical Materials. Feb 2007;29(6):679-687.

173. Hu WS, Liu ZG, Zheng JG, Hu XB, Guo XL, Gopel W. Preparation of nanocrystalline SnO2 thin films used in chemisorption sensors by pulsed laser reactive ablation. Journal of Materials Science-Materials in Electronics. Jun 1997;8(3):155-158.

174. Chadwick AV, Pooley MJ, Rammutla KE, Savin SLP, Rougier A. A comparison of the extended $\mathrm{x}$-ray absorption fine structure of nanocrystalline $\mathrm{ZrO} 2$ prepared by high-energy ball milling and other methods. Journal of Physics-Condensed Matter. 2003;15(3):431-440.

175. Tan OK, Cao W, Hu Y, Zhu W. Nanostructured oxides by high-energy ball milling technique: application as gas sensing materials. Solid State lonics. Aug 31 2004;172(1-4):309-316.

176. Yang HM, Zhang XC, Tang AD. Mechanosynthesis and gas-sensing properties of In2O3/SnO2 nanocomposites. Nanotechnology. Jun 2006;17(12):2860-2864.

177. Bhattacharjee A, Ahmaruzzaman M, Sinha T. A novel approach for the synthesis of SnO2 nanoparticles and its application as a catalyst in the reduction and photodegradation of organic compounds. Spectrochimica Acta Part a-Molecular and Biomolecular Spectroscopy. 2015;136:751-760.

178. Shiomi H, Sasaki M, Nakamura M, Matsumura Y. Preparation and characterization of glass composite using metal particles coated with semiconductive $\mathrm{SnO} 2$ fine particles obtained via sol-gel method. Journal of Materials Science-Materials in Electronics. Jun 1997;8(3):179-188.

179. Bahrami B, Khodadadi A, Kazemeini M, Mortazavi Y. Enhanced CO sensitivity and selectivity of gold nanoparticles-doped $\mathrm{SnO} 2$ sensor in presence of propane and methane. Sensors and Actuators B-Chemical. 2008;133(1):352-356.

180. Ding J, McCormick PG, Street R. Magnetic-properties of mechanically alloyed CoFe2O4. Solid State Communications. 1995;95(1):31-33.

181. Wu E, Campbell SJ, Kaczmarek WA. A Mossbauer effect study of ball-milled strontium ferrite. Journal of Magnetism and Magnetic Materials. Jan 1998;177:255-256.

182. Paulin PI, Correa RR. Characterization of high-energy ball milling of Ba hexaferrite. In: Salgado L, Filho FA, eds. Advanced Powder Technology lii. Vol 416-4; 2003: 150-155.

183. Sepelak V, Menzel M, Bergmann I, Wiebcke M, Krumeich F, Becker KD. Structural and magnetic properties of nanosize mechanosynthesized nickel ferrite. Journal of Magnetism and Magnetic Materials. May 2004;272:1616-1618.

184. Pradhan SK, Bid S, Gateshki A, Petkov V. Microstructure characterization and cation distribution of nanocrystalline magnesium ferrite prepared by ball milling. Materials Chemistry and Physics. Sep 15 2005;93(1):224-230.

185. Nan CW, Bichurin MI, Dong SX, Viehland D, Srinivasan G. Multiferroic magnetoelectric composites: Historical perspective, status, and future directions. Journal of Applied Physics. Feb 2008;103(3).

186. Hadi A, Yaacob, II, Gaik CS. Synthesis of nanocrystalline CeO2 using mechanochemical method: The effect of milling time on the particle size. In: Arof AK, Ali SAH, eds. Functional Materials and Devices. Vol 517; 2006: 105-110.

187. Li YX, Zhou XZ, Wang Y, You XZ. Preparation of nano-sized $\mathrm{CeO} 2$ by mechanochemical reaction of cerium carbonate with sodium hydroxide. Materials Letters. Jan 2004;58(12):245-249.

188. Li YX, Zhou XZ, Wang ZQ. Mechanochemical reaction of lanthanum carbonate with sodium hydroxide and preparation of lanthanum oxide nanoparticle. Journal of Rare Earths. Oct 2002;20(5):411-415.

189. Yang HM, Hu YH, Tang AD, Jin SM, Qiu GZ. Synthesis of tin oxide nanoparticles by mechanochemical reaction. Journal of Alloys and Compounds. Jan 2004;363(1-2):271-274. 
190. Dodd A, McKinley A, Saunders M, Tsuzuki T. Mechanochemical synthesis of nanocrystalline SnO2-ZnO photocatalysts. Nanotechnology. 2006;17(3):692-698.

191. Achimovicova M, Godocikova E, Balaz P, Kovac J, Satka A. Influence of soluble salt matrix on mechanochemical preparation of PbS nanoparticles. Reviews on Advanced Materials Science. 2008;18(3):216-220.

192. Deng HM, Ding J, Shi Y, Liu XY, Wang J. Ultrafine zinc oxide powders prepared by precipitation/mechanical milling. Journal of Materials Science. 2001;36(13):3273-3276.

193. Villalobos-Hernandez JR, Muller-Goymann CC. Sun protection enhancement of titanium dioxide crystals by the use of carnauba wax nanoparticles: The synergistic interaction between organic and inorganic sunscreens at nanoscale. International Journal of Pharmaceutics. Sep 2006;322(1-2):161-170.

194. Varghese OK, Gong DW, Paulose M, Ong KG, Grimes CA. Hydrogen sensing using titania nanotubes. Sensors and Actuators B-Chemical. Aug 2003;93(1-3):338-344.

195. Carp O, Huisman CL, Reller A. Photoinduced reactivity of titanium dioxide. Progress in Solid State Chemistry. 2004;32(1-2):33-177.

196. El Goresy A, Dubrovinsky L, Gillet P, Graup G, Chen M. Akaogiite: An ultra-dense polymorph of TiO2 with the baddeleyite-type structure, in shocked garnet gneiss from the Ries Crater, Germany. American Mineralogist. 2010;95(5-6):892-895.

197. Hurum DC, Agrios AG, Gray KA, Rajh T, Thurnauer MC. Explaining the enhanced photocatalytic activity of Degussa P25 mixed-phase TiO2 using EPR. Journal of Physical Chemistry B. May 2003;107(19):4545-4549.

198. Kasuga T, Hiramatsu M, Hoson A, Sekino T, Niihara K. Formation of titanium oxide nanotube. Langmuir. Jun 1998;14(12):3160-3163.

199. Kim GS, Seo HK, Godble VP, Kim YS, Yang OB, Shin HS. Electrophoretic deposition of titanate nanotubes from commercial titania nanoparticles: Application to dye-sensitized solar cells. Electrochemistry Communications. Jun 2006;8(6):961-966.

200. Zhu BL, Li KR, Feng YF, Zhang SM, Wu SH, Huang WP. Synthesis and catalytic performance of gold-loaded TiO2 nanofibers. Catalysis Letters. Oct 2007;118(1-2):55-58.

201. Jung KT, Shul YG. Synthesis of high surface area potassium hexatitanate powders by sol-gel method. Journal of Sol-Gel Science and Technology.6(3):227-233.

202. Scholl R, Wegerle R, Mutter W. Gas pressure and temperature measuring system (GTM) for in-situ data acquisition during planetary ball milling. In: Eckert J, Schlorb H, Schultz L, eds. Metastable, Mechanically Alloyed and Nanocrystalline Materials, Pts 1 and 2. Vol 343-3; 2000: 964-972.

203. Hasanpour A, Mozaffari M, Amighian J. Preparation of $\mathrm{Bi}-\mathrm{Fe} 3 \mathrm{O} 4$ nanocomposite through reduction of $\mathrm{Bi} 2 \mathrm{O} 3$ with Fe via high-energy ball milling. Physica B-Condensed Matter. Jan 2007;387(1-2):298-301.

204. Coste S, Bertrand G, Coddet C, Gaffet E, Hahn H, Sieger H. High-energy ball milling of Al2O3TiO2 powders. Journal of Alloys and Compounds. 2007;434:489-492.

205. Treacy MMJ, Ebbesen TW, Gibson JM. Exceptionally high Young's modulus observed for individual carbon nanotubes. Nature. Jun 1996;381(6584):678-680.

206. Konya Z, Zhu J, Niesz K, Mehn D, Kiricsi I. End morphology of ball milled carbon nanotubes. Carbon. 2004;42(10):2001-2008.

207. Horvath E, Kukovecz A, Konya Z, Kiricsi I. Hydrothermal conversion of self-assembled titanate nanotubes into nanowires in a revolving autoclave. Chemistry of Materials. Feb 2007;19(4):927-931.

208. Heise HM, Kuckuk R, Ojha AK, Srivastava A, Srivastava V, Asthana BP. Characterisation of carbonaceous materials using Raman spectroscopy: a comparison of carbon nanotube filters, single- and multi-walled nanotubes, graphitised porous carbon and graphite. Journal of Raman Spectroscopy. Mar 2009;40(3):344-353. 
209. Mahajan A, Kingon A, Kukovecz A, Konya Z, Vilarinho PM. Studies on the thermal decomposition of multiwall carbon nanotubes under different atmospheres. Materials Letters. Jan 1 2013;90:165-168.

210. Papp IZ, Kozma G, Puskas R, Simon T, Konya Z, Kukovecz A. Effect of planetary ball milling process parameters on the nitrogen adsorption properties of multiwall carbon nanotubes. Adsorption-Journal of the International Adsorption Society. Apr 2013;19(2-4):687-694.

211. Lu S-Y, Mao Q-J, Peng Z, Li X-D, Yan J-H. Simulation of ball motion and energy transfer in a planetary ball mill. Chinese Physics B. 2012;21(7):078201.

212. Hiura H, Ebbesen TW, Fujita J, Tanigaki K, Takada T. Role of $\mathrm{sp}(3)$ defect structures in graphite and carbon nanotubes. Nature. Jan 13 1994;367(6459):148-151.

213. Hashimoto A, Suenaga K, Gloter A, Urita K, lijima S. Direct evidence for atomic defects in graphene layers. Nature. Aug 2004;430(7002):870-873.

214. Peigney A, Laurent C, Flahaut E, Bacsa RR, Rousset A. Specific surface area of carbon nanotubes and bundles of carbon nanotubes. Carbon. 4// 2001;39(4):507-514.

215. M.D. Wiggins MCNaCRA. Crystallization Kinetics of Rutile Formation from Amorphous Titania Films. MRS Proceedings. 1995.

216. Barrett EP, Joyner LG, Halenda PP. The Determination of Pore Volume and Area Distributions in Porous Substances. I. Computations from Nitrogen Isotherms. Journal of the American Chemical Society. 1951 1951;73(1):373-380.

217. Chen Y, Liu C, Li F, Cheng HM. Pore structures of multi-walled carbon nanotubes activated by air, CO2 and KOH. Journal of Porous Materials. Apr 2006;13(2):141-146.

218. Miller FA, Wilkins $\mathrm{CH}$. Infrared Spectra and Characteristic Frequencies of Inorganic Ions. Analytical Chemistry. 1952/08/01 1952;24(8):1253-1294.

219. Templeton CC. Pressure-temperature relationship for decomposition of sodium bicarbonate from 200 to 600.degree.F. Journal of Chemical \& Engineering Data. 1978 1978;23(1):7-11.

220. Gheisari M, Mozaffari M, Acet M, Amighian J. Preparation and investigation of magnetic properties of wustite nanoparticles. Journal of Magnetism and Magnetic Materials. 2008;320(21):2618-2621.

221. Doppiu S, Schultz L, Gutfleisch O. In situ pressure and temperature monitoring during the conversion of $\mathrm{Mg}$ into $\mathrm{MgH} 2$ by high-pressure reactive ball milling. Journal of Alloys and Compounds. 2007;427(1-2):204-208.

222. Castro FJ, Fuster V, Urretavizcaya G. MgH2 synthesis during reactive mechanical alloying studied by in-situ pressure monitoring. International Journal of Hydrogen Energy. 2012;37(22):16844-16851.

223. Yang $H M$, Zhang $X C$, Tang $A D$, Ao $W Q$. Formation of zinc oxide nanoparticles by mechanochemical reaction. Materials Science and Technology. 2004;20(11):1493-1495.

224. Tsuzuki T, Pethick K, McCormick PG. Synthesis of $\mathrm{CaCO} 3$ nanoparticles by mechanochemical processing. Journal of Nanoparticle Research. Dec 2000;2(4):375-380.

225. Vidojkovic VM, Brankovic AR, Milosevic SDJ. Mechanical activation of (SeO2+Na2CO3) mixture and sodium selenite synthesis. Materials Letters. May 1997;31(1-2):55-60.

226. Liu X, Liu G, Zhao $\mathrm{H}$, et al. The quantitative monitoring of mechanochemical reaction between solid I-tartaric acid and sodium carbonate monohydrate by terahertz spectroscopy. Journal of Physics and Chemistry of Solids. 11// 2011;72(11):1245-1250.

227. Singh R, Patro PK, Kulkarni AR, Harendranath CS. Synthesis of nano-crystalline potassium sodium niobate ceramic using mechanochemical activation. Ceramics International. 8// 2014;40(7, Part B):10641-10647.

228. Sompech S, Srion A, Nuntiya A. Synthesis of perovskite-type lanthanum cobalt oxide powders by mechanochemical activation method. Scienceasia. Mar 2012;38(1):102-107.

229. Lupan O, Chow L, Chai G, Heinrich H, Park S, Schulte A. Growth of tetragonal SnO2 microcubes and their characterization. Journal of Crystal Growth. Dec 15 2008;311(1):152155. 
230. Meekes $H$, Rasing $T$, Wyder $P$, Janner A, Janssen T. Raman and infrared-spectra of the incommensurate crystal sodium-carbonate. Physical Review B. 1986;34(6):4240-4254.

231. Cukrov LM, Tsuzuki T, McCormick PG. SnO2 nanoparticles prepared by mechanochemical processing. Scripta Materialia. 5/18/ 2001;44(8-9):1787-1790.

232. Abello L, Bochu B, Gaskov A, Koudryavtseva S, Lucazeau G, Roumyantseva M. Structural characterization of nanocrystalline SnO2 by X-ray and Raman spectroscopy. Journal of Solid State Chemistry. 1998;135(1):78-85.

233. Sun J, Simon SL. The melting behavior of aluminum nanoparticles. Thermochimica Acta. 10/25/ 2007;463(1-2):32-40.

234. Kim J-H, Kang SH, Zhu K, Kim JY, Neale NR, Frank AJ. Ni-NiO core-shell inverse opal electrodes for supercapacitors. Chemical Communications. 2011;47(18):5214-5216.

235. Scardi $P$, Leoni $M$, Beyerlein $K R$. On the modelling of the powder pattern from a nanocrystalline material. Zeitschrift Fur Kristallographie. 2011;226(12):924-933.

236. F. Shahzad PK, K. Ettinger, K. Nadeem, H. Krenn, K. Pressl, P. Granitzer, Á. Kukovecz, G. Kozma, Z. Kónya, I. Letofsky-Papst. 2-Magnon Raman Behavior of NiO Nanoparticles. XII International Conference on Raman spectroscopy. Vol 255-256. United States, Boston; 2010.

237. Mate Z, Horvath E, Kozma G, et al. Size-Dependent Toxicity Differences of Intratracheally Instilled Manganese Oxide Nanoparticles: Conclusions of a Subacute Animal Experiment. Biological trace element research. May 2016;171(1):156-166.

238. Horvath E, Oszlanczi G, Mate Z, et al. Nervous system effects of dissolved and nanoparticulate cadmium in rats in subacute exposure. Journal of Applied Toxicology. Jul 2011;31(5):471-476.

239. Papp A, Oszlanczi G, Horvath E, et al. Consequences of subacute intratracheal exposure of rats to cadmium oxide nanoparticles: Electrophysiological and toxicological effects. Toxicology and Industrial Health. Nov 2012;28(10):933-941.

240. Oszlánczi G HE, Szabó A, Horváth E, Sápi A, Kozma G, Kónya Z, Paulik E, Nagymajtényi L, Papp A. Subacute exposure of rats by metal oxide nanoparticles through the airways: general toxicity and neuro-functional effects. ACTA BIOLOGICA SZEGEDIENSIS 54. 2010:165-170.

241. Sepelak V, Heitjans P, Becker KD. Nanoscale spinel ferrites prepared by mechanochemical route. Journal of Thermal Analysis and Calorimetry. Oct 2007;90(1):93-97.

242. Hajalilou A, Hashim M, Ebrahimi-Kahrizsangi R, Kamari HM, Sarami N. Synthesis and structural characterization of nano-sized nickel ferrite obtained by mechanochemical process. Ceramics International. May 2014;40(4):5881-5887.

243. Billik P, Plesch G. Mechanochemical synthesis of anatase and rutile nanopowders from TiOSO4. Materials Letters. 2// 2007;61(4-5):1183-1186.

244. Salari M, Mousavi khoie SM, Marashi P, Rezaee M. Synthesis of TiO2 nanoparticles via a novel mechanochemical method. Journal of Alloys and Compounds. 2/5/ 2009;469(1-2):386390.

245. Xiao PF, Lai MO, Lu L. Electrochemical properties of nanocrystalline TiO2 synthesized via mechanochemical reaction. Electrochimica Acta. 8/1/ 2012;76:185-191.

246. Billik P, Plesch G. Mechanochemical synthesis of nanocrystalline $\mathrm{TiO}_{2}$ from liquid $\mathrm{TiCl} 4$. Scripta Materialia. 6// 2007;56(11):979-982.

247. Ali M. Transformation and powder Characteristics of TiO2 during high energy milling. Journal of Ceramic Processing Research. 2014;15(5):290-293.

248. Ren RM, Yang ZG, Shaw LL. Polymorphic transformation and powder characteristics of TiO2 during high energy milling. Journal of Materials Science. Dec 1 2000;35(23):6015-6026.

249. Hanaor DAH, Sorrell CC. Review of the anatase to rutile phase transformation. Journal of Materials Science. Feb 2011;46(4):855-874.

250. Potari G, Madarasz D, Nagy L, et al. Rh-Induced Support Transformation Phenomena in Titanate Nanowire and Nanotube Catalysts. Langmuir. Mar 5 2013;29(9):3061-3072. 
251. Hanaor DAH, Sorrell CC. Review of the anatase to rutile phase transformation. J Mater Sci Journal of Materials Science : Full Set - Includes 'Journal of Materials Science Letters'. 2011;46(4):855-874.

252. Reidy DJ, Holmes JD, Morris MA. The critical size mechanism for the anatase to rutile transformation in TiO 2 and doped-TiO 2. JECS Journal of the European Ceramic Society. 2006;26(9):1527-1534.

253. Zhang H, F. Banfield J. Thermodynamic analysis of phase stability of nanocrystalline titania. Journal of Materials Chemistry. 1998;8(9):2073-2076.

254. Yuan Z-Y, Su B-L. Titanium oxide nanotubes, nanofibers and nanowires. Colloids and Surfaces A: Physicochemical and Engineering Aspects. 7/14/ 2004;241(1-3):173-183.

255. Kordas K, Mohl M, Konya Z, Kukovecz A. Layered titanate nanostructures: perspectives for industrial exploitation. Translational Materials Research. Mar 2015;2(1).

256. Liu G, Li G, Qiu X, Li L. Synthesis of ZnO/titanate nanocomposites with highly photocatalytic activity under visible light irradiation. Journal of Alloys and Compounds. 7/29/ 2009;481(12):492-497.

257. Schuerer B, Elser MJ, Sternig A, Peukert W, Diwald O. Delamination and Dissolution of Titanate Nanowires: A Combined Structure and in Situ Second Harmonic Generation Study. Journal of Physical Chemistry C. Jun 30 2011;115(25):12381-12387.

258. Kukovecz A, Hodos N, Horvath E, Radnoczi G, Konya Z, Kiricsi I. Oriented crystal growth model explains the formation of titania nanotubes. Journal of Physical Chemistry B. Sep 2005;109(38):17781-17783.

259. Tian J, Zhao ZH, Kumar A, Boughton RI, Liu H. Recent progress in design, synthesis, and applications of one-dimensional $\mathrm{TiO} 2$ nanostructured surface heterostructures: a review. Chemical Society Reviews. Oct 2014;43(20):6920-6937.

260. Godbole VP, Kim GS, Dar MA, et al. Hot filament chemical vapour deposition processing of titanate nanotube coatings. Nanotechnology. Aug 2005;16(8):1186-1191.

261. Shi XM, Zhou WP, Ma DL, et al. Electrospinning of Nanofibers and Their Applications for Energy Devices. Journal of Nanomaterials. 2015.

262. Wu D, Liu J, Zhao XN, Li AD, Chen YF, Ming NB. Sequence of events for the formation of titanate nanotubes, nanofibers, nanowires, and nanobelts. Chemistry of Materials. Jan 2006;18(2):547-553. 